Prepared in cooperation with the

Federal Emergency Management Agency

\title{
Flood of April 2-3, 2005, Neversink River Basin, New York
}

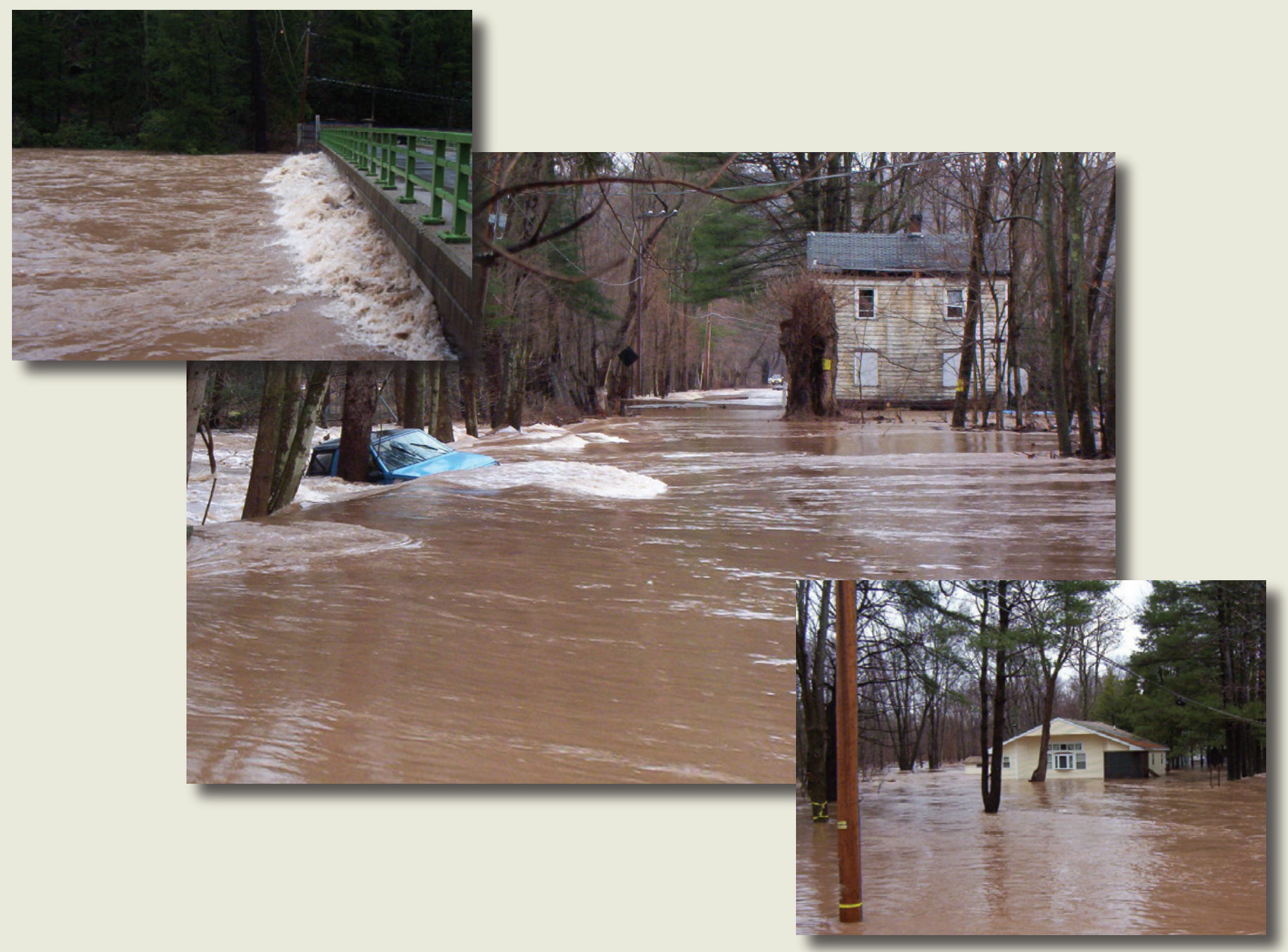

\section{Open-File Report 2006-1319}


Cover. Center photo: Neversink River flow over Guymard Turnpike at Myers Grove, New York. Left photo: Neversink River at upstream side of Guymard Turnpike bridge at Myers Grove, New York. Right photo: Neversink River overflow at intersection of Guymard Turnpike and Shore Drive at Myers Grove, New York, taken April 3, 2005. 


\section{Flood of April 2-3, 2005, Neversink River Basin, New York}

By Thomas P. Suro and Gary D. Firda

Prepared in cooperation with the

Federal Emergency Management Agency

Open-File Report 2006-1319 


\section{U.S. Department of the Interior DIRK KEMPTHORNE, Secretary}

\section{U.S. Geological Survey \\ Mark D. Myers, Director}

\section{U.S. Geological Survey, Reston, Virginia: 2006}

For product and ordering information:

World Wide Web: http://www.usgs.gov/pubprod

Telephone: 1-888-ASK-USGS

For more information on the USGS — the Federal source for science about the Earth, its natural and living resources, natural hazards, and the environment:

World Wide Web: http://www.usgs.gov

Telephone: 1-888-ASK-USGS

Any use of trade, product, or firm names is for descriptive purposes only and does not imply endorsement by the U.S. Government.

Although this report is in the public domain, permission must be secured from the individual copyright owners to reproduce any copyrighted materials contained within this report.

Suggested citation:

Suro, T.P. and Firda, G.D., 2006, Flood of April 2-3, 2005, Neversink River Basin, New York: U.S. Geological Survey Open-File Report 2006-1319, 98 p. 


\section{Contents}

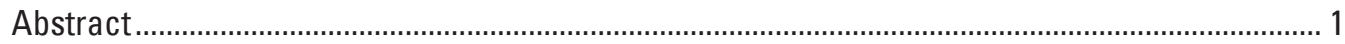

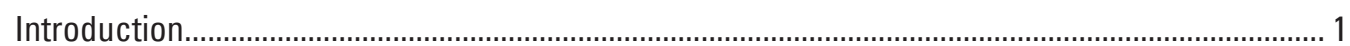

Rainfall in the Neversink River Basin ....................................................................................... 1

Flood of April 2-3, 2005 Discharge and Frequency ........................................................................... 3

Effects of Neversink Reservoir on Downstream Flooding ............................................................... 8

Peak Water-Surface Elevations at Flood Study Sites.................................................................. 13

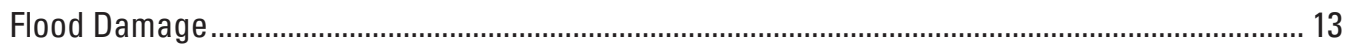

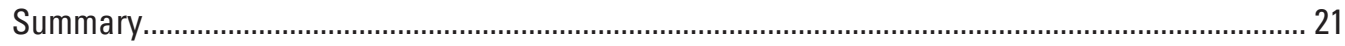

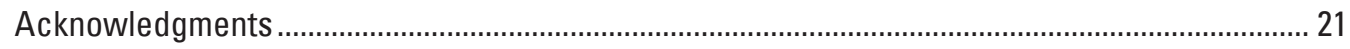

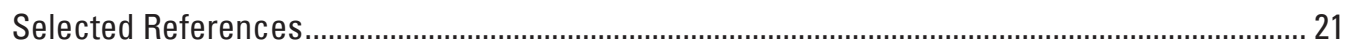

Appendix 1. Site Descriptions and High-Water Marks at Study Sites, Flood of April 2-3, 2005, in the Neversink River Basin, New York ............................................ 23

Appendix 2. Selected Photographs of Flood Damage During the Flood of April 2-3, 2005, in the Neversink River Basin and Surrounding Areas.

\section{Figures}

1. Map showing pertinent geographic features of southeastern New York and precipitation from the storm of April 2-3, 2005.

2. Graph showing cumulative rainfall during April 2-3, 2005, recorded at the National Weather Service site at Claryville, N.Y.

3. Map showing locations of selected U.S. Geological Survey stream-gaging stations in the Delaware River basin, N.Y.

4-6. Graphs showing-

4. Discharge hydrographs for selected stream-gaging stations in the Neversink River basin, March 27 to April 6, 2005

5. Peak discharges at selected stream-gaging stations in the Delaware River basin, N.Y., as a function of drainage area during the flood of April 2-3, 2005, and previous maximum known discharges

6. Hourly inflow, outflow, diversions, and water-surface elevation at the Neversink Reservoir, N.Y., March 27 to April 6, 2005

7. Map showing locations of 25 high-water-mark sites chosen for study in the Neversink River basin, N.Y., during the flood of April 2-3, 2005

8. Graphs showing peak water-surface elevations at selected sites in the Neversink River basin, N.Y., during April 2-3, 2005, and flood-recurrence values from Federal Emergency Management Agency flood-insurance studies

9. Photograph showing Main Street bridge (U.S. Route 6) over the Neversink River at Port Jervis, N.Y., April 3, 2005 


\section{Tables}

1. Total rainfall from April 2-3, 2005, at selected locations in the Neversink River basin and surrounding areas

2. Rainfall-frequency relations for storms of 3-, 6-, 12-, and 24-hour durations at Claryville, N.Y.

3. Historical flood peaks, and peak discharges during the flood of April 2-3, 2005, at selected U.S. Geological Survey stream-gaging stations in the Delaware River basin, N.Y.

4. Historical peak discharges, and discharges during the flood of April 2-3, 2005, at selected U.S. Geological Survey stream-gaging stations in the Neversink River basin, N.Y.

5. Peak water-surface elevations at 25 high-water-mark sites in the Neversink River basin, N.Y., during the flood of April 2-3, 2005, and corresponding water-surface elevations for 10-, 50-, 100-, and 500-year flood-recurrence intervals.

\section{Conversion Factors, Datum, and Acronyms}

\begin{tabular}{|c|c|c|}
\hline Multiply & By & To obtain \\
\hline \multicolumn{3}{|c|}{ Length } \\
\hline inch (in.) & 2.54 & centimeter $(\mathrm{cm})$ \\
\hline foot $(\mathrm{ft})$ & 0.3048 & meter $(\mathrm{m})$ \\
\hline mile (mi) & 1.609 & kilometer $(\mathrm{km})$ \\
\hline \multicolumn{3}{|c|}{ Area } \\
\hline acre & 0.4047 & hectare (ha) \\
\hline acre & 0.004047 & square kilometer $\left(\mathrm{km}^{2}\right)$ \\
\hline square foot $\left(\mathrm{ft}^{2}\right)$ & 0.09290 & square meter $\left(\mathrm{m}^{2}\right)$ \\
\hline square mile $\left(\mathrm{mi}^{2}\right)$ & 259.0 & hectare (ha) \\
\hline square mile $\left(\mathrm{mi}^{2}\right)$ & 2.590 & square kilometer $\left(\mathrm{km}^{2}\right)$ \\
\hline \multicolumn{3}{|c|}{ Volume } \\
\hline cubic foot $\left(\mathrm{ft}^{3}\right)$ & 0.02832 & cubic meter $\left(\mathrm{m}^{3}\right)$ \\
\hline acre-foot (acre-ft) & 1,233 & cubic meter $\left(\mathrm{m}^{3}\right)$ \\
\hline million gallons (Mgal) & 3,785 & cubic meter $\left(\mathrm{m}^{3}\right)$ \\
\hline \multicolumn{3}{|c|}{ Flow rate } \\
\hline acre-foot per day (acre-ft/d) & 0.01427 & cubic meter per second $\left(\mathrm{m}^{3} / \mathrm{s}\right)$ \\
\hline cubic foot per second $\left(\mathrm{ft}^{3} / \mathrm{s}\right)$ & 0.02832 & cubic meter per second $\left(\mathrm{m}^{3} / \mathrm{s}\right)$ \\
\hline $\begin{array}{l}\text { cubic foot per second per square mile } \\
{\left[\left(\mathrm{ft}^{3} / \mathrm{s}\right) / \mathrm{mi}^{2}\right]}\end{array}$ & 0.01093 & $\begin{array}{l}\text { cubic meter per second per square } \\
\text { kilometer }\left[\left(\mathrm{m}^{3} / \mathrm{s}\right) / \mathrm{km}^{2}\right]\end{array}$ \\
\hline million gallons per day (Mgal/d) & 0.04381 & cubic meter per second $\left(\mathrm{m}^{3} / \mathrm{s}\right)$ \\
\hline
\end{tabular}

Temperature in degrees Celsius $\left({ }^{\circ} \mathrm{C}\right)$ may be converted to degrees Fahrenheit $\left({ }^{\circ} \mathrm{F}\right)$ as follows:

$$
{ }^{\circ} \mathrm{F}=\left(1.8 x^{\circ} \mathrm{C}\right)+32
$$

Temperature in degrees Fahrenheit $\left({ }^{\circ} \mathrm{F}\right)$ may be converted to degrees Celsius $\left({ }^{\circ} \mathrm{C}\right)$ as follows:

$$
{ }^{\circ} \mathrm{C}=\left({ }^{\circ} \mathrm{F}-32\right) / 1.8
$$


Vertical coordinate information is referenced to National Geodetic Vertical Datum of 1929 (NGVD 29).

Horizontal coordinate information is referenced to the North American Datum of 1983 (NAD 83).

$\begin{array}{ll}\text { ACRONYMS USED IN REPORT } \\ \text { NWS } & \text { National Weather Service } \\ \text { FEMA } & \text { Federal Emergency Management Agency } \\ \text { USGS } & \text { U.S. Geological Survey } \\ \text { NGS } & \text { National Geodetic Survey }\end{array}$




\title{
Flood of April 2-3, 2005, Neversink River Basin, New York
}

\author{
By Thomas P. Suro and Gary D. Firda
}

\section{Abstract}

Heavy rain on April 2-3, 2005 produced rainfall amounts of 3 inches to almost 6 inches within a 36-hour period throughout the Delaware River basin. Major flooding occurred in the East and West Branches of the Delaware River and their tributaries, the main stem of the Delaware River and the Neversink River, a major tributary to the Delaware River. The resultant flooding damaged hundreds of homes, caused millions of dollars in damage to infrastructure in Orange and Sullivan Counties, and forced more than 1,000 residents to evacuate their homes. A total of 20 New York counties were declared Federal disaster areas. Some of the most extensive flooding occurred along the Neversink and Delaware Rivers in Orange and Sullivan Counties, New York. Disaster recovery assistance from the April 2005 flooding in New York stood at almost \$35 million in 2005, at which time more than 3,400 New Yorkers had registered for Federal aid. All U.S. Geological Survey stream-gaging stations on the Neversink River below the Neversink Reservoir recorded peak water-surface elevations higher than those recorded during the September 2004 flooding. Peak water-surface elevations at some study sites on the Neversink River exceeded the 500-year flood elevation as documented in flood-insurance studies by the Federal Emergency Management Agency. Flood peaks at some long-term U.S. Geological Survey streamgaging stations were the highest ever recorded. Several U.S. Geological Survey stream-gaging stations on the Delaware River also recorded peak water-surface elevations that exceeded those recorded during the September 2004 flooding.

\section{Introduction}

Heavy rainfall amounts of 3 inches to almost 6 inches produced widespread flooding in the Neversink and Delaware River basins during April 2-3, 2005. The National Weather service (NWS) recorded rainfall amounts of 3.00 inches at Port Jervis, N.Y., 4.10 inches at Claryville, N.Y., and as much as 5.69 inches at East Jewett, N.Y. (National Oceanic and Atmospheric Administration, 2005b). Officials in the town of Deer Park declared a state of emergency on April 3 as more than 1,000 residents were displaced due to the flooding. Mandatory evacuations were declared along the Neversink River, forcing residents to move to town shelters and motels until the flood waters receded. Officials estimated flood damage in Orange and Sullivan Counties at almost $\$ 60$ million. More than 150 homes in Orange County were severely damaged as a result of this flooding and have been condemned. Subsequently, 20 counties (11 eligible for individual assistance) in New York were declared Federal disaster areas (Federal Emergency Management Agency, 2005).

This report documents the rainfall amounts and peak water-surface elevations in the Neversink River basin during April 2-3, 2005. Federal Emergency Management Agency (FEMA) personnel selected 25 study sites located along the Neversink River to be included in the study. Peak watersurface elevations were surveyed, described, and photographed by U.S. Geological Survey (USGS) personnel. Descriptions and maps of individual sites are presented in appendix 1. Peak water-surface elevations at some study sites exceeded the 500year flood elevation as documented in flood-insurance studies by FEMA. Peak-of-record discharges were recorded at several USGS stream-gaging stations. The Neversink Reservoir was full and spilling at the beginning of the rainfall event on April 2, 2005, but still attenuated the peak flow to downstream communities.

\section{Rainfall in the Neversink River Basin}

Although total statewide precipitation for March 2005 in New York was slightly below normal, the Hudson Valley, Eastern Plateau, and Coastal divisions of New York all reported above normal precipitation (National Oceanic and Atmospheric Administration, 2005d). The storm system during April 2-3, 2005 moved up the Appalachians and through the Mid-Atlantic region into New York and New England and delivered heavy rain to southeastern New York (fig. 1). This system caused widespread rainfalls of more than 3 inches with some local areas reporting rainfall totals of more than 5 inches in a 36-hour period (National Oceanic and Atmospheric Administration, 2005b).

This early April event followed the 1 to 2 inches of rain from the previous storm system on March 28-29 (National Oceanic and Atmospheric Administration, 2005a); this system left rivers and streams flowing at above base levels. On April 1 the daily mean flow at the USGS streamgaging station Neversink River at Claryville, N.Y., was at 


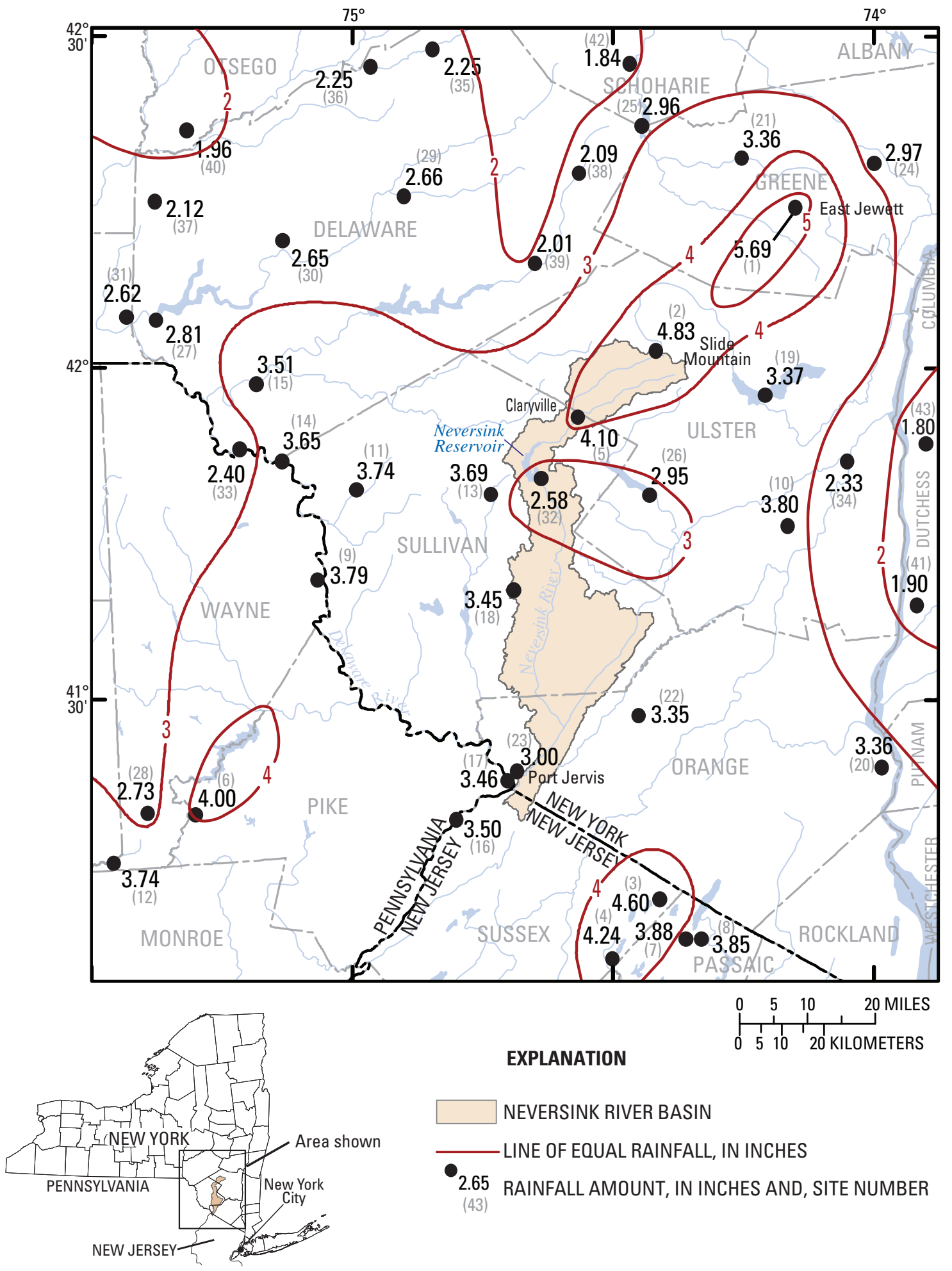

Figure 1. Pertinent geographic features of southeastern New York and rainfall amounts from the storm of April 2-3, 2005. Site numbers are listed in table 1. 
a level that is exceeded only 20 percent of the time or less. The maximum recorded rainfall during April 2-3, 2005 in the Neversink River basin was 4.10 inches at Claryville, N.Y. Total rainfall amounts recorded at 43 selected locations in New York, New Jersey, and Pennsylvania are listed in table 1.

Rainfall amounts and frequencies for Claryville, N.Y.

(fig. 1), which is located near the headwaters of the main stem of the Neversink River, are listed in table 2.

The rainfall intensity during the April 2-3, 2005 storm was not very high in the Neversink River basin, with only a 2-year recurrence interval for a 24-hour storm at Claryville. Generally, the rainfall frequencies for selected locations in the Neversink River basin were less than 5 years. Most of the rainfall at Claryville was recorded between 4:00 a.m. and midnight on Saturday April 2, 2005 (National Oceanic and Atmospheric Administration, 2005c). A plot of cumulative rainfall at the NWS site at Claryville, N.Y. (fig. 2) indicates a fairly uniform rainfall from the early morning of April 2 until about 4:00 p.m. when rainfall rates increased and remained at higher levels until about 10:00 p.m. The data also indicate that a continued uniform rainfall until about 4:00 p.m. on April 3 concluded the 36-hour rainfall event (National Oceanic and Atmospheric Administration, 2005c).

Although rainfall intensity did not approach record rates, 3 or more inches of rain falling on snow-covered terrain combined with daytime temperatures of 50 degrees Fahrenheit or greater at several locations in the Neversink River basin produced significant runoff. The NWS observations at Slide Mountain, N.Y. (located near the headwaters of the West Branch of the Neversink River) reported about 41 inches of snow in March, the deepest snow reported in New York during the month (National Oceanic and Atmospheric Administration, 2005d). Before the rainfall event in late March, there was about 22 inches of snow at Slide Mountain. On April 1 the reported snow depth was 12 inches, and by April 3 only 4 inches of snow was reported. The 7-day runoff for the period prior to April 4 was determined to be more than 7.2 inches at the stream-gaging station Neversink River near Claryville, N.Y.

\section{Flood of April 2-3, 2005 Discharge and Frequency}

The locations of 26 USGS stream-gaging stations in the Delaware River basin cited in this report are presented in figure 3. Historic flood peaks and peak discharges for the flood of April 2-3, 2005, at these stations are presented in table 3.

Peak discharges were recorded during the evening of Saturday, April 2, 2005, at the USGS stream-gaging stations located upstream from the Neversink Reservoir on the East and West Branches of the Neversink River. Peak discharges were recorded between the early morning hours and noon on Sunday, April 3, 2005, at the stream-gaging stations located downstream from the Neversink Reservoir.
Table 1. Total rainfall from April 2-3, 2005, at selected locations in the Neversink River basin and surrounding areas.

[Data provided by National Oceanic and Atmospheric Administration (2005b) and New York City Department of Environmental Protection (written commun., 2005); selected data shown in fig. 1]

\begin{tabular}{|c|c|c|}
\hline Site number & Site name & $\begin{array}{c}\text { Total rainfall } \\
\text { (inches) }\end{array}$ \\
\hline 1 & East Jewett, N.Y. & 5.69 \\
\hline 2 & Slide Mountain, N.Y. & 4.83 \\
\hline 3 & Highland Lakes, N.J. & 4.60 \\
\hline 4 & Canistear Reservoir, N.J. & 4.24 \\
\hline 5 & Claryville, N.Y. & 4.10 \\
\hline 6 & Greentown, $\mathrm{Pa}$. & 4.00 \\
\hline 7 & West Milford, N.J. & 3.88 \\
\hline 8 & Hewitt, N.J. & 3.85 \\
\hline 9 & Milanville, $\mathrm{Pa}$. & 3.79 \\
\hline 10 & Mohonk Lake, N.Y. & 3.80 \\
\hline 11 & North Branch, N.Y. & 3.74 \\
\hline 12 & Gouldsboro, $\mathrm{Pa}$. & 3.74 \\
\hline 13 & Liberty, N.Y. & 3.69 \\
\hline 14 & Long Eddy, N.Y. & 3.65 \\
\hline 15 & Fishs Eddy, N.Y. & 3.51 \\
\hline 16 & Montague, N.J. & 3.50 \\
\hline 17 & Matamoras, Pa. & 3.46 \\
\hline 18 & Monticello, N.Y. & 3.45 \\
\hline 19 & Ashokan Reservoir, N.Y. & 3.37 \\
\hline 20 & West Point, N.Y. & 3.36 \\
\hline 21 & Windham, N.Y. & 3.36 \\
\hline 22 & Middletown, N.Y. & 3.35 \\
\hline 23 & Port Jervis, N.Y. & 3.00 \\
\hline 24 & Cairo, N.Y. & 2.97 \\
\hline 25 & Schoharie Reservoir, N.Y. & 2.96 \\
\hline 26 & Rondout Reservoir, N.Y. & 2.95 \\
\hline 27 & Cannonsville Reservoir, N.Y. & 2.81 \\
\hline 28 & Sterling Township, Pa. & 2.73 \\
\hline 29 & Delhi, N.Y. & 2.66 \\
\hline 30 & Walton, N.Y. & 2.65 \\
\hline 31 & Deposit, N.Y. & 2.62 \\
\hline 32 & Neversink Reservoir, N.Y. & 2.58 \\
\hline 33 & Lordville, N.Y. & 2.40 \\
\hline 34 & Rosendale, N.Y. & 2.33 \\
\hline 35 & Davenport, N.Y. & 2.25 \\
\hline 36 & West Davenport, N.Y. & 2.25 \\
\hline 37 & Masonville, N.Y. & 2.12 \\
\hline 38 & Roxbury, N.Y. & 2.09 \\
\hline 39 & Margaretville, N.Y. & 2.01 \\
\hline 40 & Unadilla, N.Y. & 1.96 \\
\hline 41 & Poughkeepsie, N.Y. & 1.90 \\
\hline 42 & Lansing Manor, N.Y. & 1.84 \\
\hline 43 & Rhinebeck, N.Y. & 1.80 \\
\hline
\end{tabular}


Table 2. Rainfall-frequency relations for storms of 3-, 6-, 12-, and 24-hour durations at Claryville, N.Y.

[Data from U.S. Weather Bureau, 1961. Location is shown in fig. 1]

\begin{tabular}{ccccc}
\hline \multirow{2}{*}{$\begin{array}{c}\text { Recurrence interval } \\
\text { (years) }\end{array}$} & \multicolumn{4}{c}{ Rainfall, in inches for selected duration } \\
\cline { 2 - 5 } & $\mathbf{3}$ hours & $\mathbf{6}$ hours & $\mathbf{1 2}$ hours & $\mathbf{2 4}$ hours \\
\hline 2 & 1.9 & 2.5 & 3.3 & 3.5 \\
5 & 2.5 & 3.0 & 4.0 & 4.6 \\
10 & 2.9 & 3.9 & 4.6 & 5.8 \\
25 & 3.4 & 4.3 & 5.5 & 6.5 \\
50 & 3.9 & 5.0 & 6.0 & 7.0 \\
100 & 4.1 & 5.5 & 6.8 & 8.0 \\
\hline
\end{tabular}

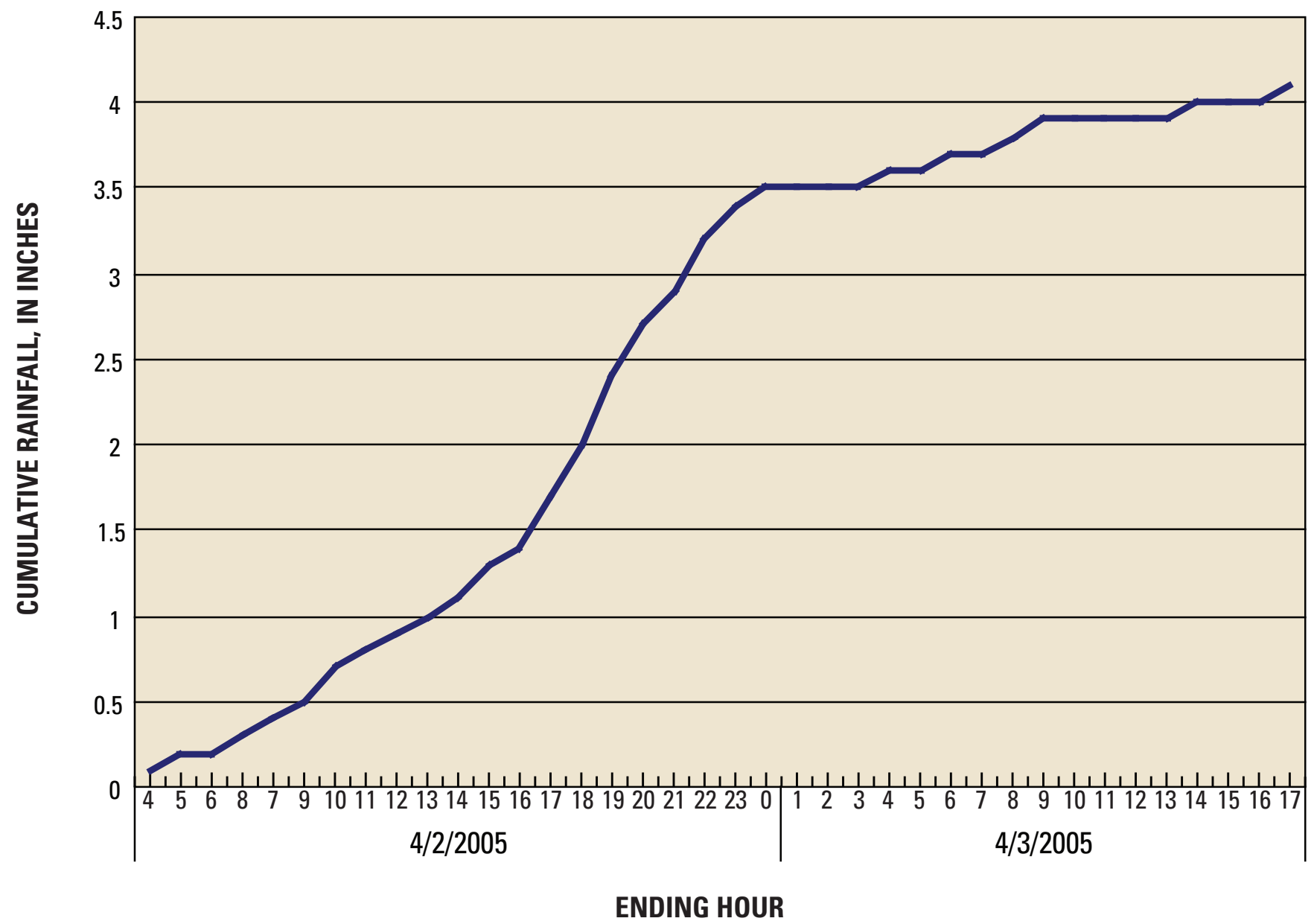

Figure 2. Cumulative rainfall during April 2-3, 2005, recorded at the National Weather Service site at Claryville, N.Y. 

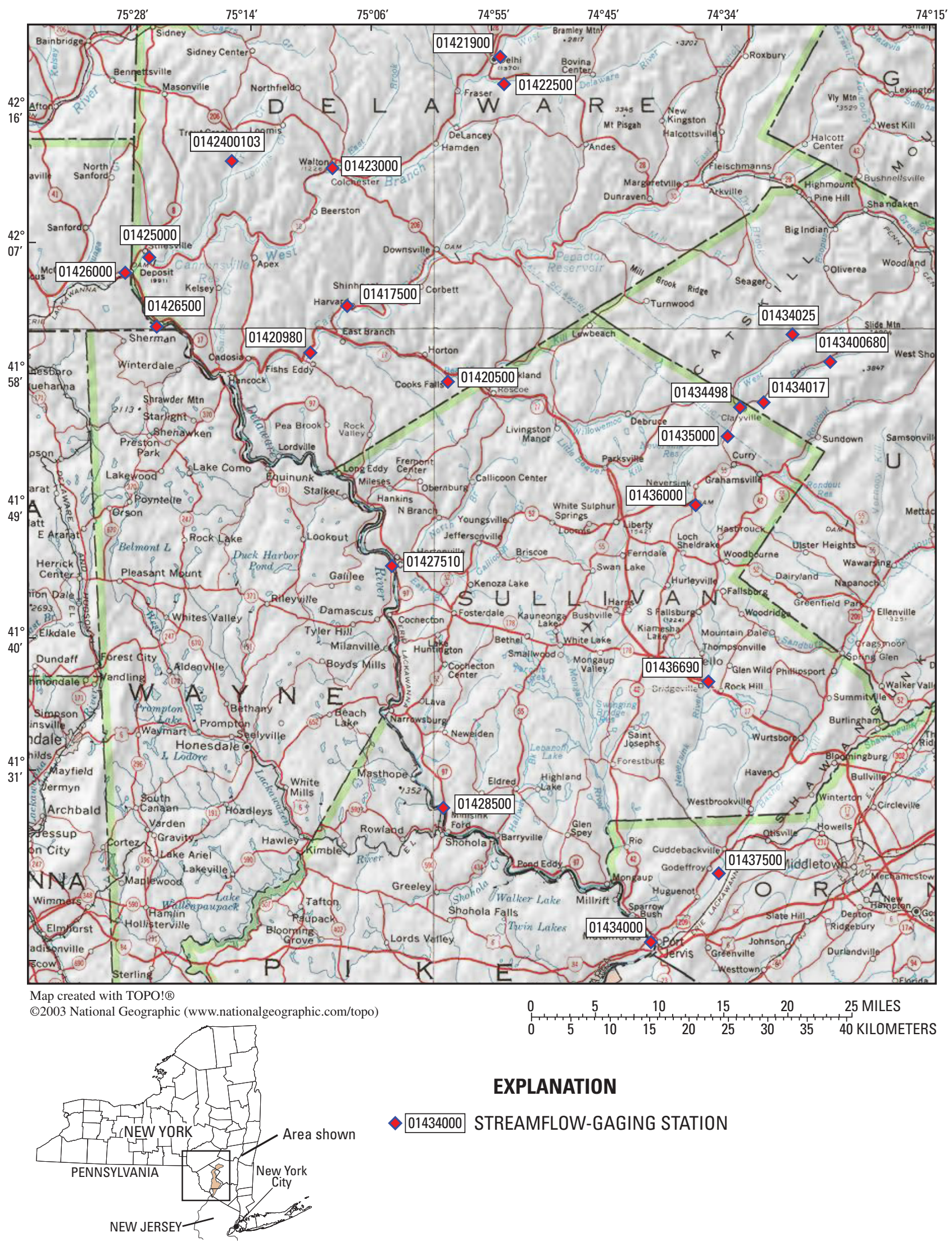

\section{EXPLANATION}

01434000 STREAMFLOW-GAGING STATION

Figure 3. Locations of selected U.S. Geological Survey stream-gaging stations in the Delaware River basin, N.Y. (See table 3 for station names and flood-related data.) 


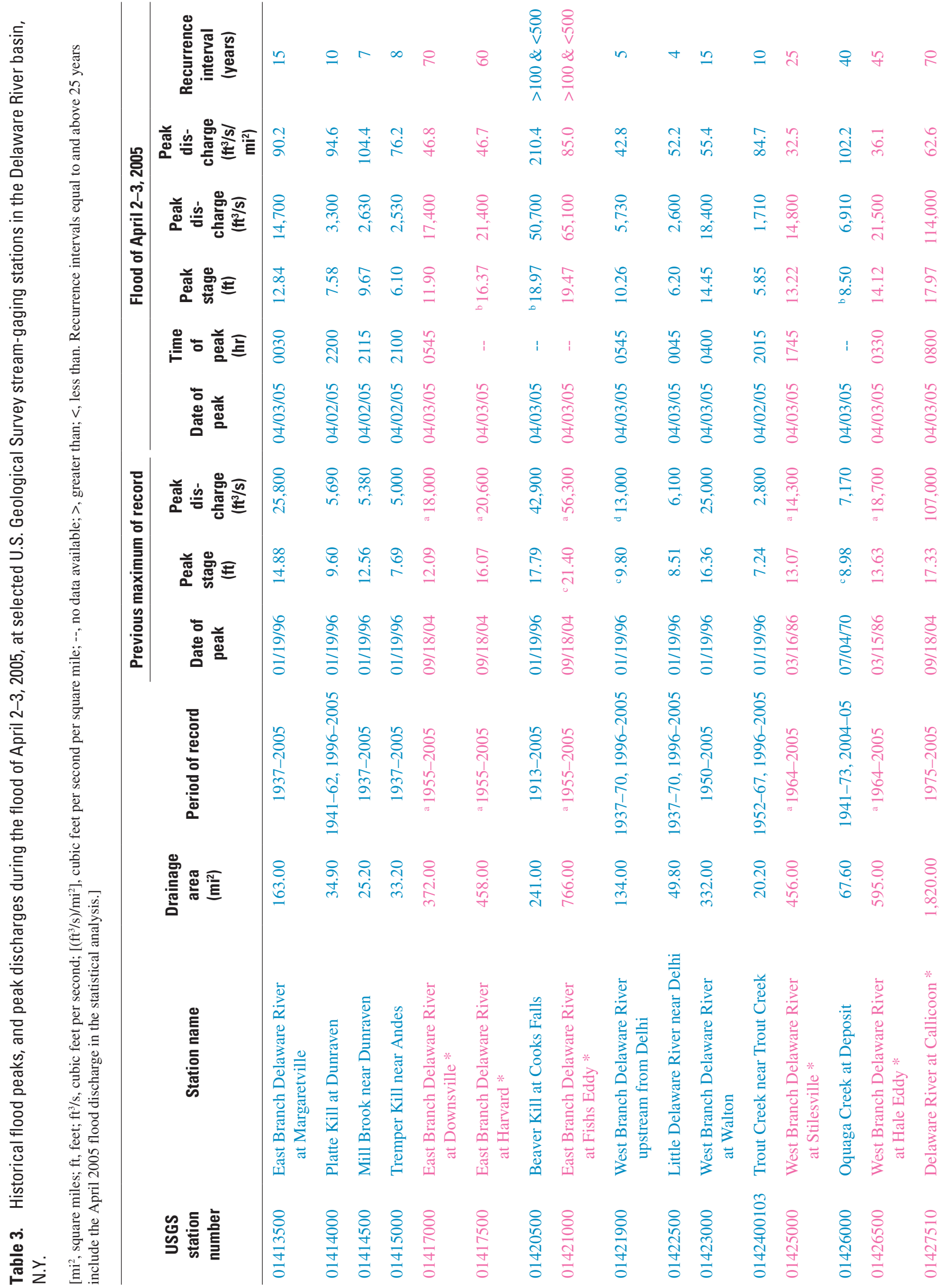




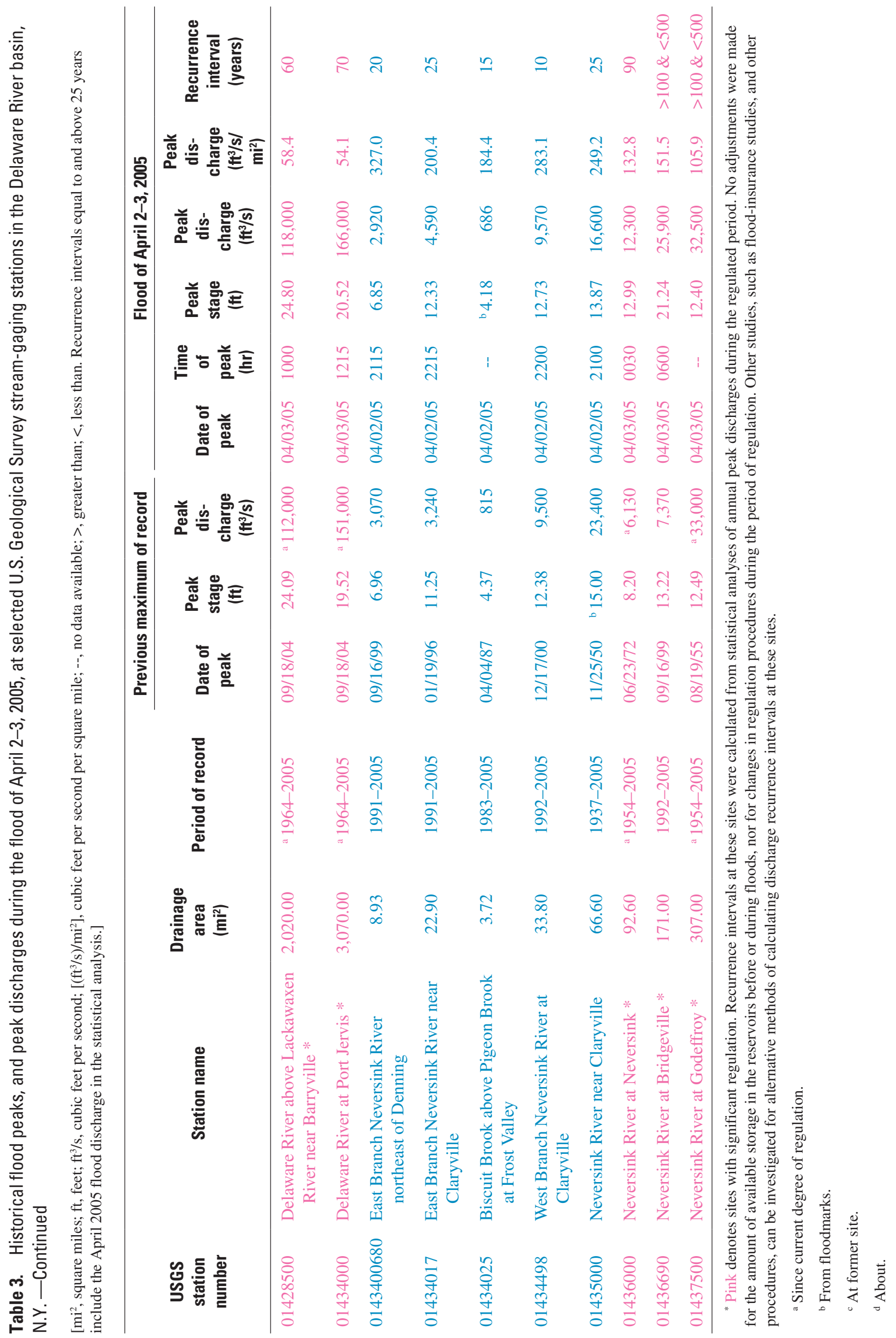


Frequency analysis of annual flood-peak data recorded at stream-gaging stations provides a means of estimating the probability of occurrence of a given discharge. Flood frequency is commonly expressed in terms of recurrence interval or the probability of being exceeded (one is the reciprocal of the other). The 100-year flood, for example, has a probability of 0.01 ( 1 percent chance) of being equaled or exceeded in any given year. Recurrence intervals for stream-gaging stations listed in this report were calculated by fitting systematic annual peak-discharge data to a log-Pearson type III distribution (Interagency Advisory Committee on Water Data, 1982). Recurrence intervals at stream-gaging stations with significant regulation were calculated from statistical analyses of annual peak discharges during the regulated period only. No adjustments were made for the amount of available storage in the reservoirs before or during floods, or for changes in regulation procedures during the period of regulation.

Recurrence intervals at USGS stream-gaging stations with unregulated streamflows (stations upstream from Neversink Reservoir) ranged from 10 to 25 years, whereas recurrence intervals at USGS stream-gaging stations with regulated streamflows (stations downstream from Neversink Reservoir) ranged from 90 years to greater than 100 years.

The Neversink River at Neversink, N.Y., stream-gaging station recorded a new period-of-record (since regulation, 1954) maximum of $12,300 \mathrm{ft}^{3} / \mathrm{s}$. The peak discharge at the Neversink River at Godeffroy, N.Y., stream-gaging station, which has been in operation since 1937 , was about 1.5 percent less than the period of record maximum of $33,000 \mathrm{ft}^{3} / \mathrm{s}$ set in August of 1955.

Discharge hydrographs at four USGS stream-gaging stations (one upstream from the Neversink Reservoir and three downstream from the Neversink Reservoir) in the Neversink River basin for the period March 27 to April 6, 2005, are presented in figure 4.

Peak streamflow at other stations on unregulated reaches in the Delaware River basin generally remained below a 40-year recurrence interval except at Beaver Kill at Cooks Falls, N.Y., where the peak had a recurrence interval of greater than 100 years. Peak discharges at selected sites in the Neversink River basin are plotted as a function of drainage area in figure 5 as well as previous peak-of-record discharges at stations with regulated and unregulated streamflows.

\section{Effects of Neversink Reservoir on Downstream Flooding}

The Neversink Reservoir began storage operations on June 2, 1953, and reached full storage capacity for the first time in April 1955. The usable capacity of the reservoir between the minimum operating level of 1,319.0 ft above NGVD 29 and crest of the spillway, elevation 1,440.0 ft above NGVD 29, is 34,931 Mgal. Dead storage below diversion sill and outlet sill (elevation 1,314.0 ft) is 1,680 Mgal. The contents of the Neversink Reservoir were at 100.1 percent of usable capacity on April 1, 2005. The reservoir water-surface elevation was $1,440.66 \mathrm{ft}$ relative to NGVD $29(0.66 \mathrm{ft}$ above the spillway elevation of 1,440.0 ft) on April 1 (fig. 6). The Neversink Reservoir reached a new record maximum watersurface elevation since operations began in 1953 of $1,443.66 \mathrm{ft}$ on April 3, 2005.

The USGS stream-gaging station Neversink River near Claryville, N.Y., recorded a peak discharge of $16,600 \mathrm{ft}^{3} / \mathrm{s}$ at 9:00 p.m. on April 2. The drainage area above this streamgaging station is about 72 percent of the total contributing area to the Neversink Reservoir. The peak discharge recorded at this station per unit of contributing drainage area yields a peak runoff of $249 \mathrm{ft}^{3} / \mathrm{s} / \mathrm{mi}^{2}$. Applying this peak runoff to the entire Neversink Reservoir drainage yields an estimated maximum inflow of 23,100 ft $3 / \mathrm{s}$ to the reservoir on April 2, 2005.

Hydrographs of hourly inflow and outflow, diversions to New York City's water-supply system, and water-surface elevations for Neversink Reservoir for the period March 27 to April 6 are presented in figure 6. Reservoir elevations are referenced to NGVD of 1929. The maximum computed daily mean inflow to Neversink Reservoir was estimated as $6,440 \mathrm{ft}^{3} / \mathrm{s}$.

On the basis of recorded data from the USGS Neversink River at Neversink, N.Y., stream-gaging station, the combined flow through the release valves and over the spillway produced a daily discharge of $6,910 \mathrm{ft}^{3} / \mathrm{s}$ on April 3. The USGS Neversink River at Neversink, N.Y., stream-gaging station recorded a peak discharge of $12,300 \mathrm{ft}^{3} / \mathrm{s}$ on April 3. Although the Neversink Reservoir was at full capacity and spilling before the storm, the reservoir still attenuated the flood peak.

Historical peak discharges and discharges for the April 2-3, 2005, flood at stations on the Neversink River before and after regulation are presented in table 4 . These peak discharges indicate that during the floods of 1955 and 1996, the existence of the reservoir and the fact that its contents were average (several feet below the spillway) significantly reduced the effects of flooding on downstream communities.

The peak discharge at the Neversink River near Claryville stream-gaging station (inflow to reservoir) during the August 1955 flood was 9,350 $\mathrm{ft}^{3} / \mathrm{s}$. The reservoir was at about 89 percent of usable capacity at the end of July 1955 , and all of the inflow was stored without spilling during the August 1955 flood. During the 1996 flood, the peak discharge at the Neversink River near Claryville stream-gaging station was $12,700 \mathrm{ft}^{3} / \mathrm{s}$, but the Neversink Reservoir was at about 60 percent of capacity prior to the flood at the end of December due to drought conditions (Lumia, 1998) and again was able to store all of the runoff from the contributing drainage area without spilling. The peak discharges recorded at the Neversink River at Godeffroy, N.Y., stream-gaging station during the August 1955, January 1996, and April 2005 floods were $33,000 \mathrm{ft}^{3} / \mathrm{s}, 8,220 \mathrm{ft}^{3} / \mathrm{s}$ and $32,500 \mathrm{ft}^{3} / \mathrm{s}$, respectively (table 4 ). 


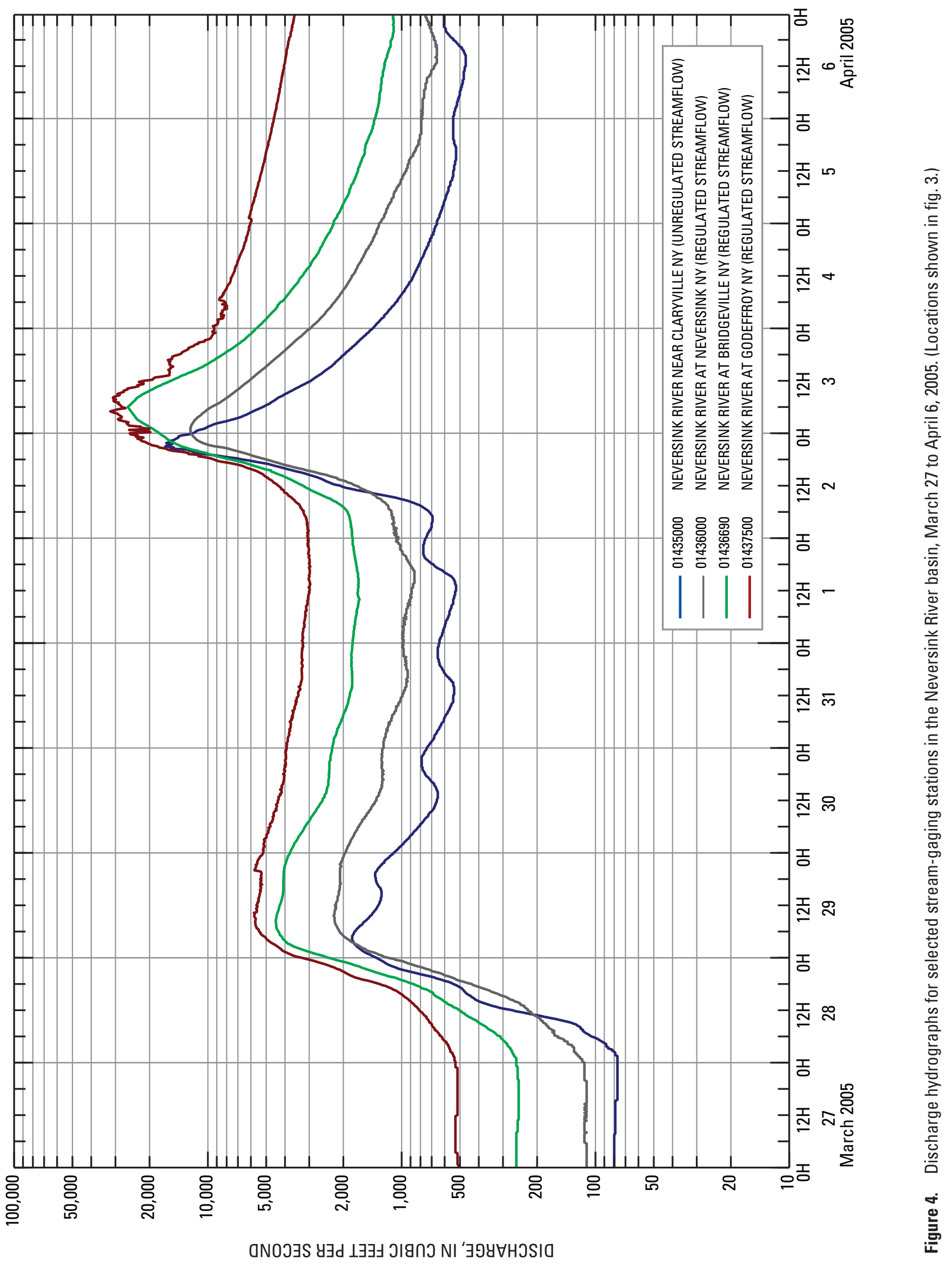




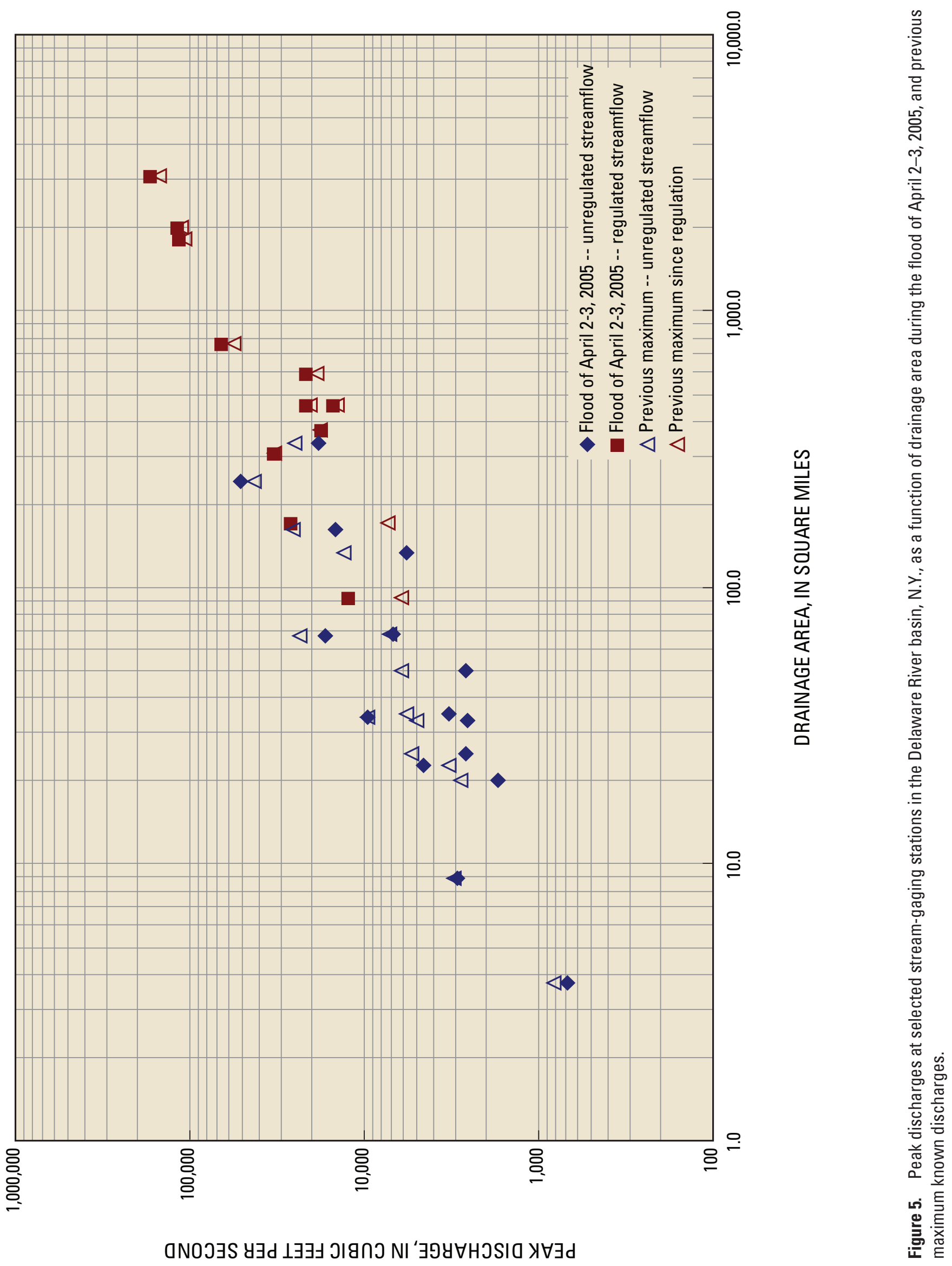




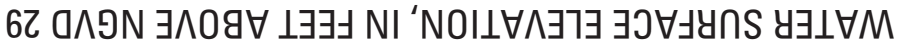

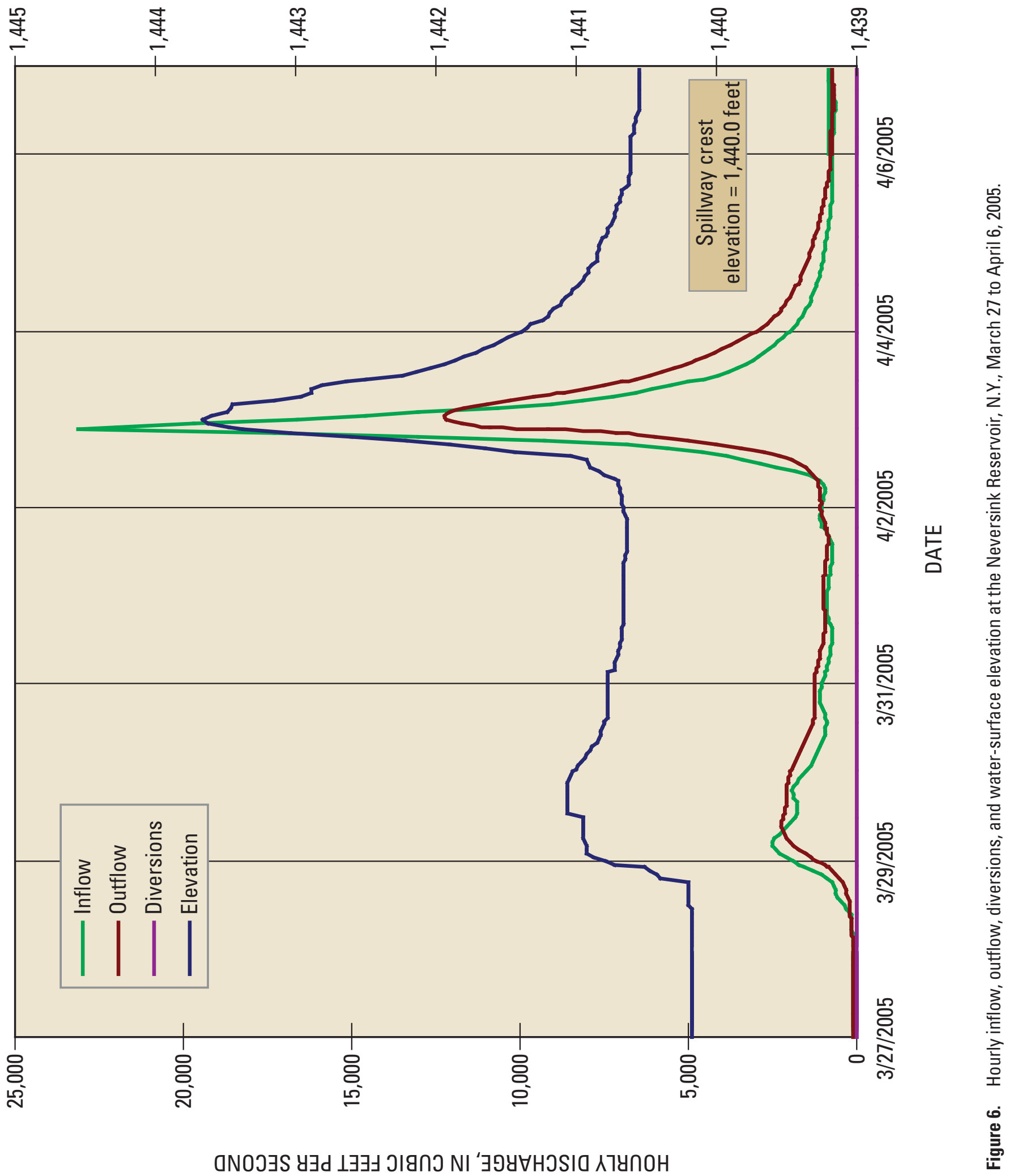




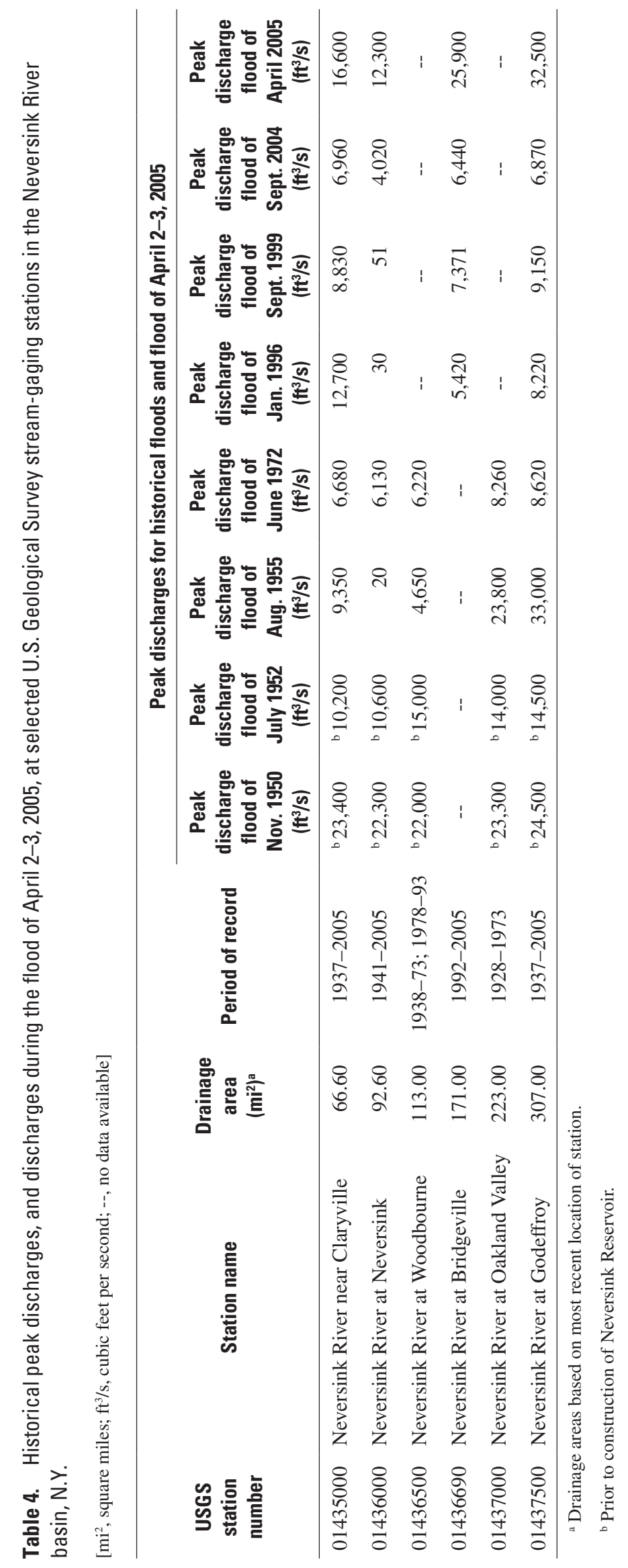




\section{Peak Water-Surface Elevations at Flood Study Sites}

Measurements of peak water-surface elevations were made at 25 sites along the Neversink River immediately downstream from Neversink Reservoir near the town of Neversink to the confluence of the Delaware and Neversink Rivers at Port Jervis, N.Y. (fig. 7). High-water marks at each site were surveyed to obtain peak water-surface elevations and were referenced to NGVD 29. A data correction to convert elevations from NGVD 29 to North American Vertical Datum of 1988 (NAVD 88) at each site was calculated by using the National Geodetic Survey (NGS) North American Vertical Datum Conversion Utility (National Oceanic and Atmospheric Administration, 2005g). At sites associated with a bridge, high-water-marks were obtained upstream and downstream of the structure. At most selected sites associated with bridges, thalweg elevations also were determined.

The accuracy of high-water marks was rated subjectively by field personnel as "excellent," "good," "fair," or "poor," according to guidelines of Benson and Dalrymple (1967). "Excellent" means the reported high-water mark is considered within $0.02 \mathrm{ft}$ of the true high-water elevation; "good" within $0.05 \mathrm{ft}$; "fair" within $0.10 \mathrm{ft}$; and "poor" implies less than "fair" accuracy. High-water-mark description, photographs, location (latitude and longitude) and location with respect to a nearby bridge or other structure were documented and are presented in appendix 1. High-water-mark locations described as "left bank" or "right bank" are in relation to an observer facing downstream.

Peak water-surface elevations for the April 2005 flood were compared with flood-profile elevations published in FEMA flood-insurance studies (Federal Emergency Management Agency; 1991, 1999, 2002). High-water-mark elevations and published FEMA 10-, 50-, 100-, and 500-year flood elevations are compiled in table 5. Flood elevations at 10-, 50-, 100-, and 500-year recurrence intervals and those determined for the flood of April 2-3, 2005, for the Neversink River are plotted in figure 8.

FEMA flood-insurance studies are not available for the area immediately downstream of Neversink Reservoir (site 1) to the area of Thompsonville (site 7), and in the vicinity of site 11 ; therefore, a comparison of high-water mark elevations could not be made at these sites. Comparison of high-water-mark elevations with FEMA flood-insurance studies from the area of Bridgeville (site 8) to the area of Interstate Route 84 at Port Jervis (site 25) indicated that peak water-surface elevations ranged from between the 10- and 50year flood profiles to higher than the 500-year flood profiles (fig. 8; table 5). Peak water-surface elevations in the area of Bridgeville (sites 8-10) generally ranged between the 10- and 50 -year flood profiles. Peak water-surface elevations from the area of Oakland Valley (site 12) to the area of Huguenot (site 19) generally were higher than the 500-year flood profile. Peak water-surface elevations from the area of Hamilton Street at Port Jervis (site 20) to the area of Interstate Route 84 at Port Jervis (site 25) generally ranged between the 100- and 500 -year flood profiles or ranged between the 50- and 100year flood profiles, depending upon which flood-insurance study is used for comparison. All flood-profile recurrence intervals noted above are based on published FEMA floodinsurance studies.

\section{Flood Damage}

A state of emergency was declared by officials in several towns in Orange County between April 2 and April 3, 2005. Hundreds of residents of the city of Port Jervis were evacuated, and more than 1,000 residents of the town of Deer Park were displaced by floodwaters (Times HeraldRecord, 2005a). In Deer Park and Port Jervis, floodwaters from the Neversink River caused extensive property damage, flooded the high-school bus garage, and encroached upon the rear entrance of Bon Secours Community Hospital.

Floodwaters also damaged the Anna Kuhl Elementary School in Cuddebackville (The River Reporter, 2005). In addition, more than 150 homes in Orange County were condemned because of flood damage and two bodies were recovered and are presumed to be victims of the flooding (The Times Union, 2005). Orange and Sullivan Counties were among the counties declared as Federal disaster areas. More than 3,400 New York residents, business owners, and government agencies have applied for disaster-recovery assistance. Assistance to the victims of the April flooding in New York has reached almost \$35 million (Federal Emergency Management Agency, 2005). Some selected photographs of flood damage to the hardest hit areas of Myers Grove and Port Jervis, N.Y., are included in appendix 2. 


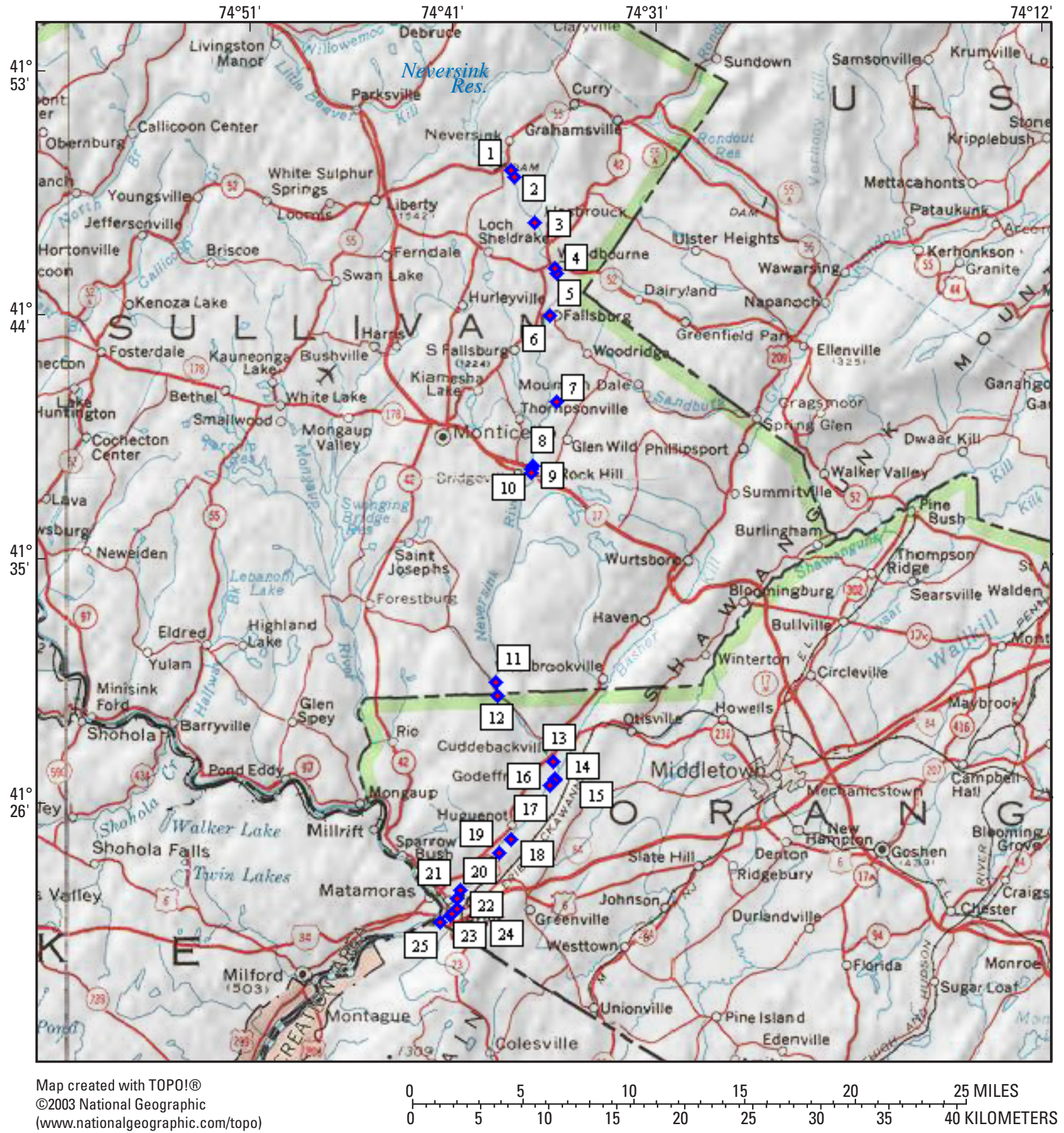

\section{EXPLANATION}

High-water-mark site chosen for the Neversink River basin, New York, flood of April 2-3, 2005

Figure 7. Locations of 25 high-water-mark sites chosen for study in the Neversink River basin, N.Y., during the flood of April 2-3, 2005. Site numbers are listed in table 5. 


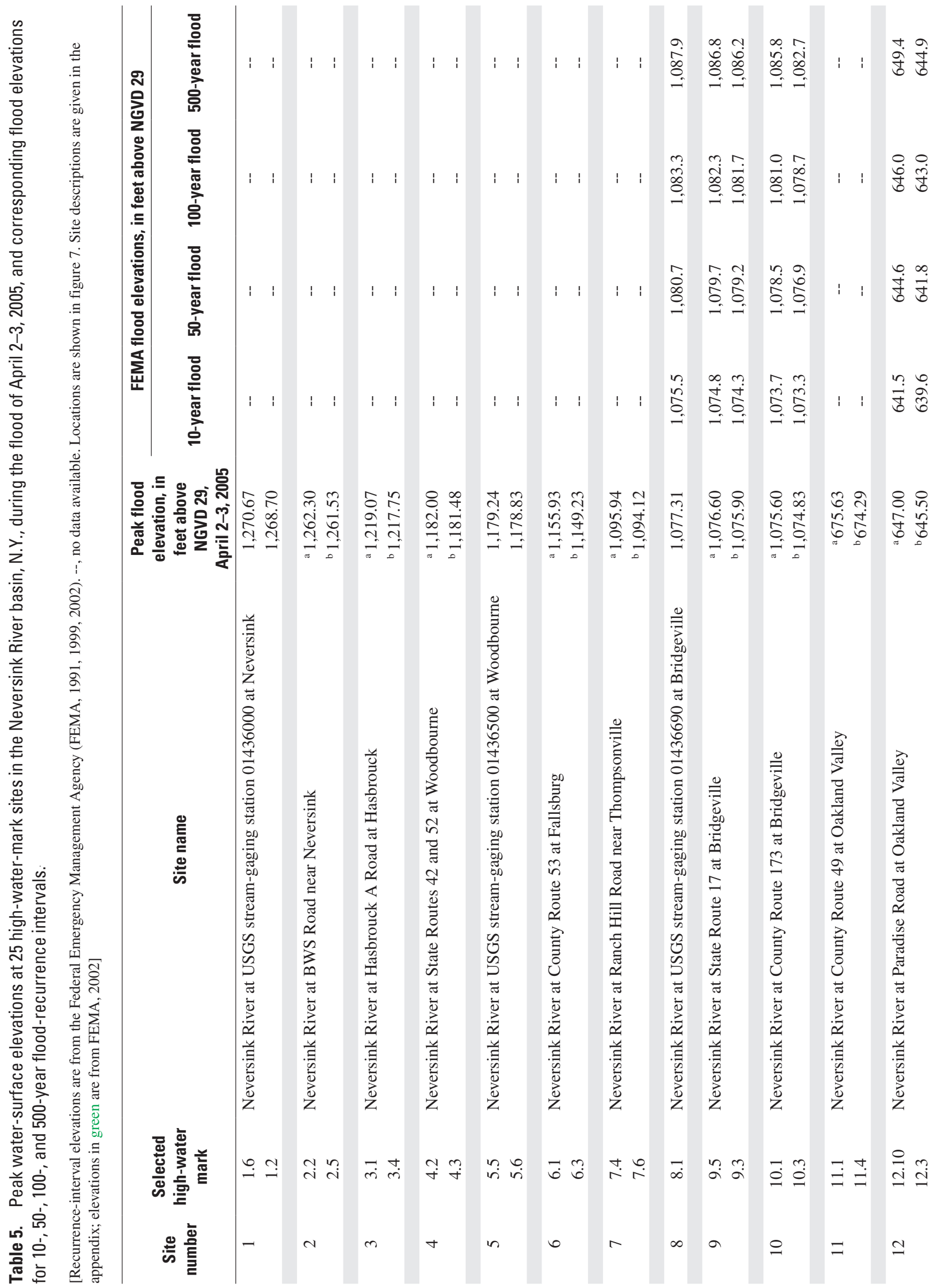




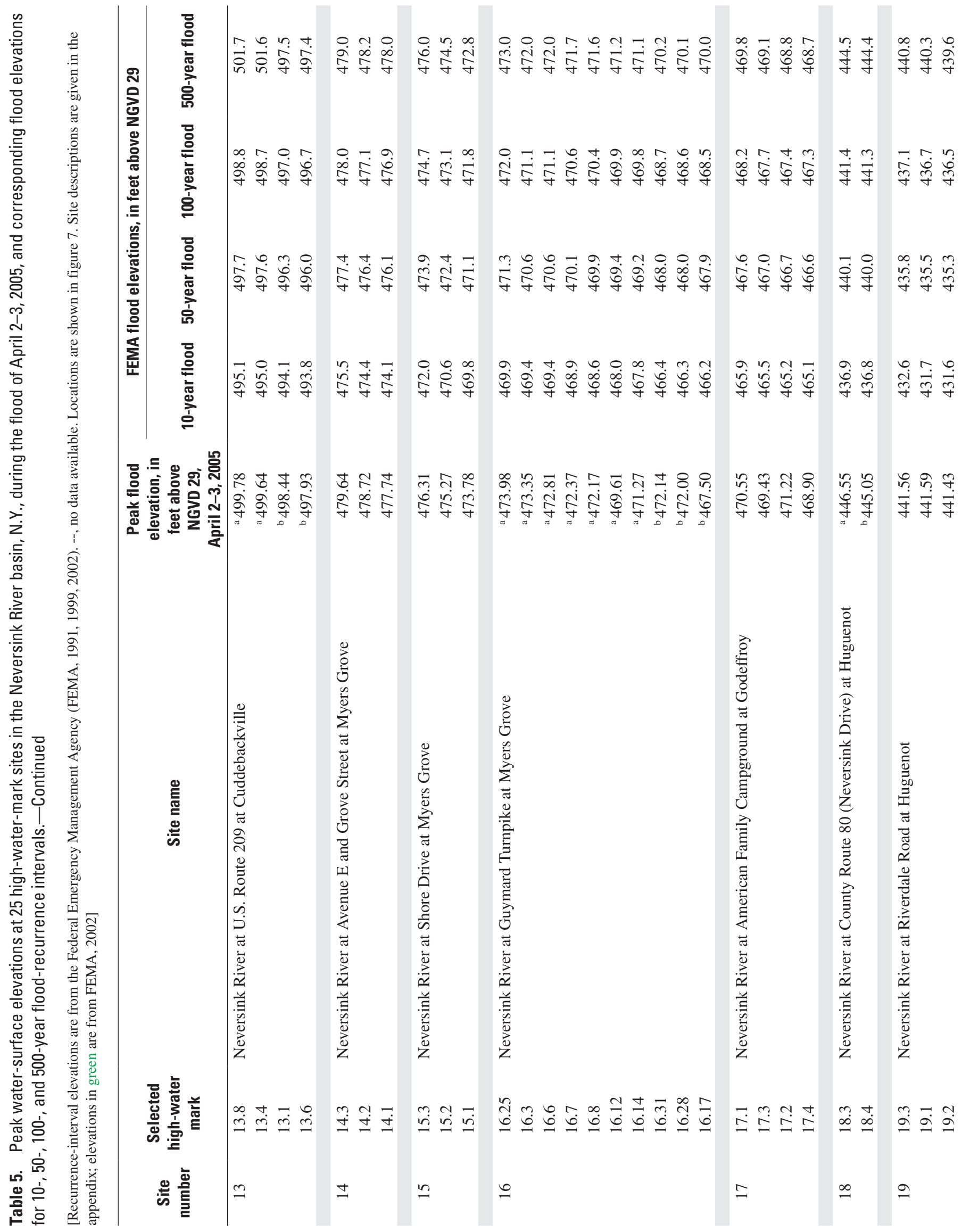




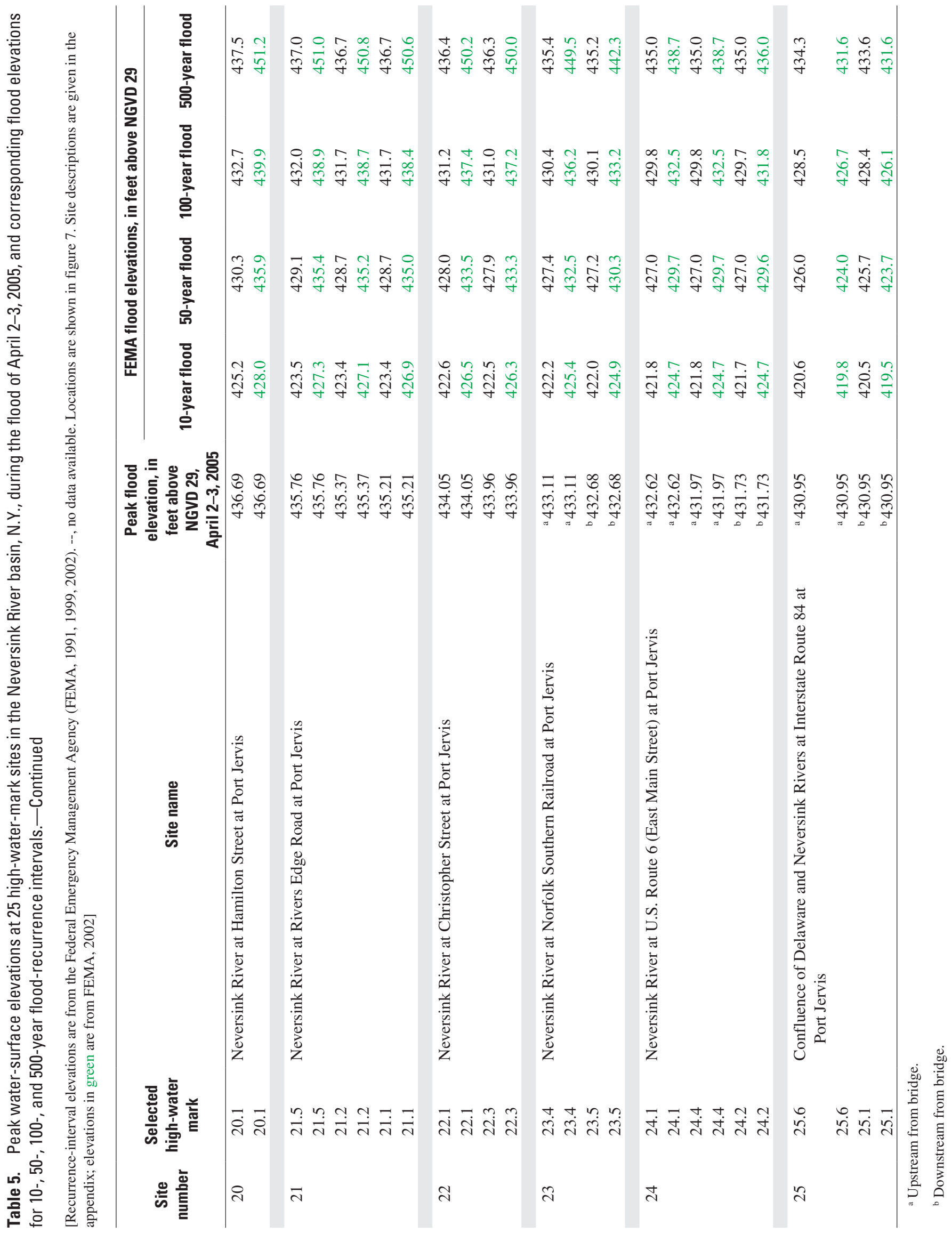



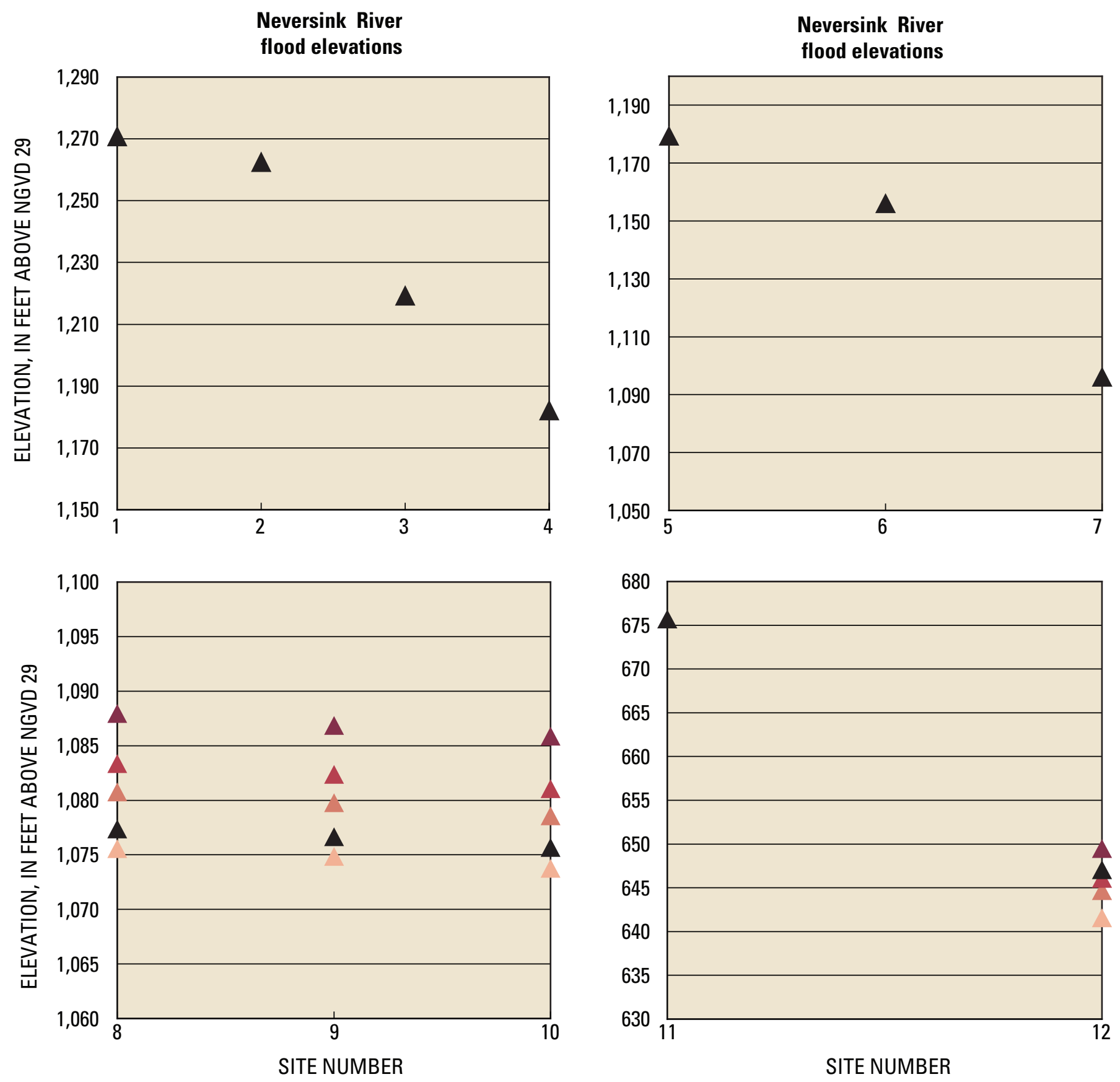

\section{EXPLANATION}

$\triangle 500$-year elevation (FEMA, 1991,1999)

$\triangle 100$-year elevation (FEMA, 1991,1999)

50-year elevation (FEMA, 1991,1999)

10-year elevation (FEMA, 1991,1999)

$\triangle$ April 2-3, 2005, flood elevation' (USGS)

Figure 8. Peak water-surface elevations at selected sites in the Neversink River basin, N.Y., during April 2-3, 2005, and floodrecurrence values from Federal Emergency Management Agency flood-insurance studies. Site names and locations are listed in table 5. 

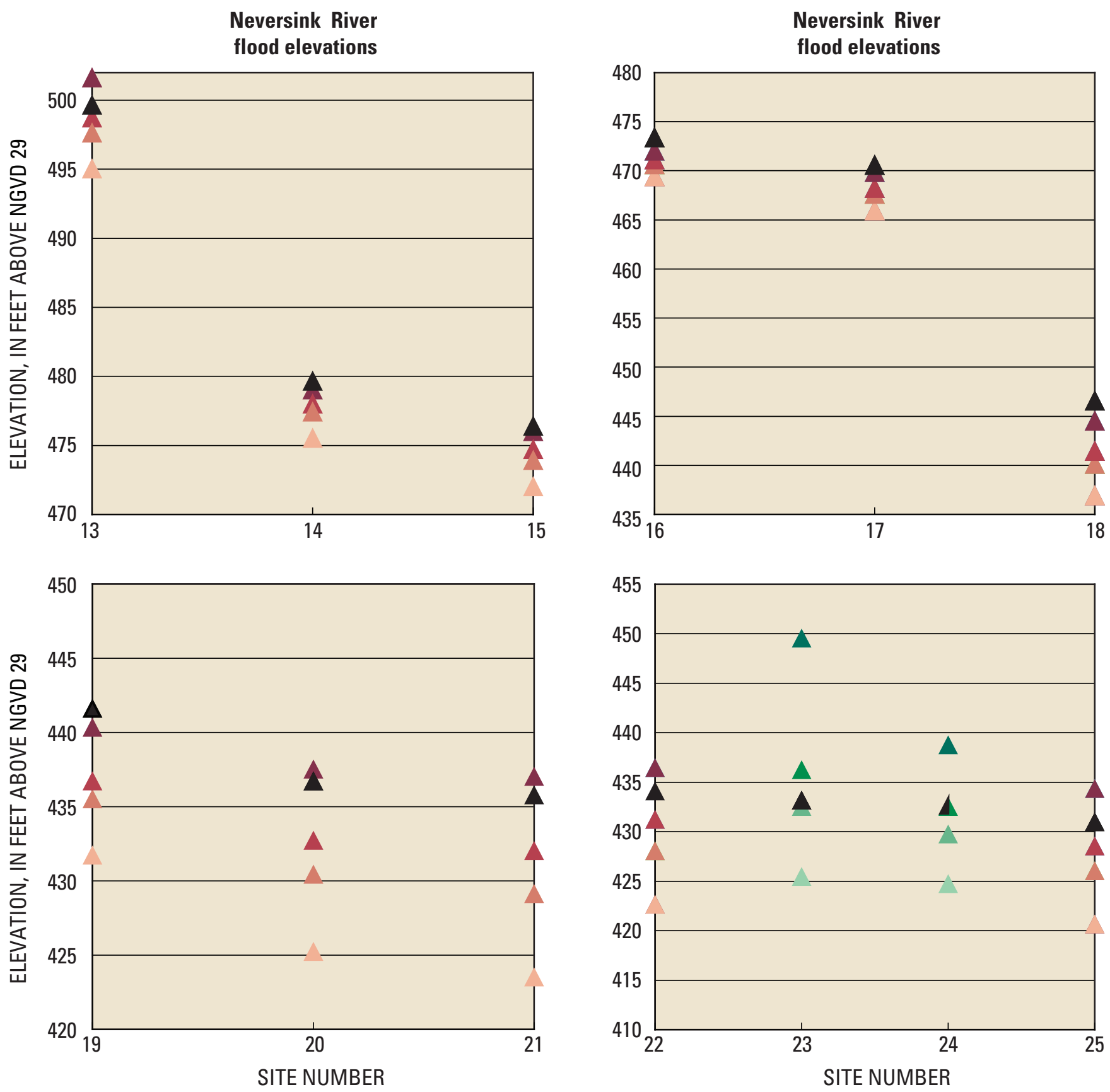

\500-year elevation (FEMA, 1991,1999) $\triangle 100$-year elevation (FEMA, 1991,1999) $\triangle 50$-year elevation (FEMA, 1991,1999) $\triangle 10$-year elevation (FEMA, 1991,1999)
$\Delta$ 500-year elevation (FEMA, 2002)
$\triangle 100$-year elevation (FEMA, 2002)
$\triangle 50$-year elevation (FEMA, 2002)
$\triangle 10$-year elevation (FEMA, 2002)

$\Delta$ April 2-3, 2005, flood elevation (USGS)

Figure 8. Peak water-surface elevations at selected sites in the Neversink River basin, N.Y., during April 2-3, 2005, and floodrecurrence values from Federal Emergency Management Agency flood-insurance studies. Site names and locations are listed in table 5.-Continued 


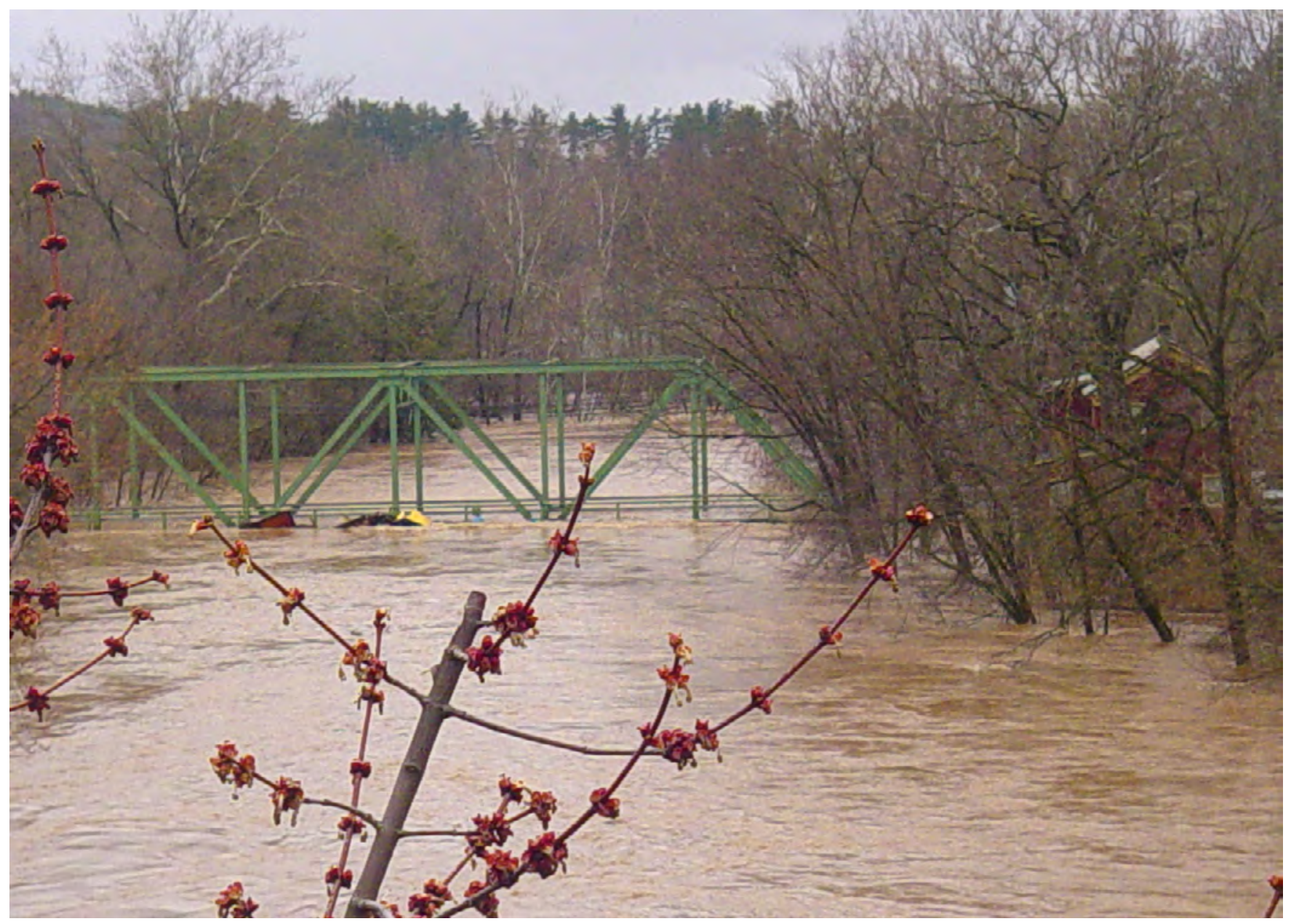

Figure 9. Main Street bridge (U.S. Route 6) over the Neversink River at Port Jervis, N.Y., April 3, 2005. Photograph by Laurie Fuller, Port Jervis, N.Y. 


\section{Summary}

Heavy rain in the region produced rainfall amounts of 3 inches to almost 6 inches within a 36-hour period from April 2 to 3, 2005. These rains came only days after the March 28-29, 2005, storm soaked the area with 1 to 2 inches of rain that left rivers and streams flowing at above base levels. The mean daily streamflow on April 1 at the USGS streamgaging station Neversink River at Claryville, N.Y., was at a level that is exceeded only 20 percent of the time or less. This storm produced peak water-surface elevations with recurrence intervals greater than 500 years, as indicated by flood elevations documented in FEMA flood-insurance studies. The Neversink Reservoir was at greater than 100 percent of capacity and already spilling at the start of this event. More than 1,000 people were asked to evacuate, and more than 150 homes were condemned due to flood damage. Orange and Sullivan Counties were among the 20 counties in New York declared as Federal disaster areas and eligible for assistance. Federal disaster assistance for this flood in New York was almost \$35 million. Some of the most devastating damage in the Neversink River basin was in the areas of Myers Grove and Godeffroy, N.Y.

Peak water-surface elevations at 25 study sites on the Neversink River were surveyed and, where possible, were compared to flood profiles in the flood-insurance studies published by FEMA. The recurrence intervals for the peak water-surface elevations at many of the study sites were determined to be greater than 100 years. The recurrence intervals for the peak water-surface elevations in the Myers Grove and Godeffroy areas were determined to be greater than 500 years. Several USGS stream-gaging stations on the Neversink River recorded the highest peak discharges since the Neversink Reservoir began operations in 1953. The USGS stream-gaging station Neversink River at Godeffroy, N.Y., has been in operation since 1937, and recorded a peak discharge within 1.5 percent of the historical peak-of-record maximum recorded in $1955\left(33,000 \mathrm{ft}^{3} / \mathrm{s}\right.$, August 19, 1955).

\section{Acknowledgments}

Thanks are extended to the USGS hydrologists and hydrologic technicians who collected the data for this report during and after the flood: L.T. Brooks, A.M. Gearwar, M.E. Hendricks, T.F. Hoffman, R. Lumia, K. McGrath, Kevin D. Reisig, and B.J. Zatorsky.

\section{Selected References}

Benson, M.A., and Dalrymple, Tate, 1967, General field and office procedures for indirect discharge measurements: U.S. Geological Survey Techniques of Water-Resources Investigations, book 3, chap. A1, $30 \mathrm{p}$.

Federal Emergency Management Agency, 1991, Flood insurance study, Town of Thompson, Sullivan County, New York: Federal Emergency Management Agency, Federal Insurance Administration, $21 \mathrm{p}$.

Federal Emergency Management Agency, 1999, Flood insurance study, Town of Deerpark, Orange County, New York: Federal Emergency Management Agency, Federal Insurance Administration, $22 \mathrm{p}$.

Federal Emergency Management Agency, 2002, Flood insurance study, City of Port Jervis, Orange County, New York: Federal Emergency Management Agency, Federal Insurance Administration, $19 \mathrm{p}$.

Federal Emergency Management Agency, 2005, News release, disaster assistance to New York nears \$35 million: Federal Emergency Management Agency, no. 1589-078.

Interagency Advisory Committee on Water Data, 1982, Guidelines for determining flood flow frequency, Bulletin 17B of the Hydrology Subcommittee: Reston, Va., U.S. Geological Survey, Office of Water Data Coordination, 183 p.

Lumia, Richard, 1998, Flood of January 19-20, 1996, in New York State: U.S. Geological Survey Water-Resources Investigations Report 97-4252, 61 p.

National Oceanic and Atmospheric Administration, 2005a, Climatological data, New York, March 2005: Asheville, N.C., National Climatic Data Center, v. 117, no. 4, 42 p.

National Oceanic and Atmospheric Administration, 2005b, Climatological data, New York, April 2005: Asheville, N.C., National Climatic Data Center, v. 117, no. 4, 42 p.

National Oceanic and Atmospheric Administration, 2005c, Hourly precipitation data, New York, April 2005: Asheville, N.C., National Climatic Data Center, v. 55, no. 4, $20 \mathrm{p}$.

National Oceanic and Atmospheric Administration, 2005d, New York climate, March 2005: Ithaca, N.Y., Northeast Regional Climate Center, Cornell University, v. 105, 13 p.

National Oceanic and Atmospheric Administration, 2005e, New York climate, April 2005: Ithaca, N.Y., Northeast Regional Climate Center, Cornell University, v. 105, 11 p. 
National Oceanic and Atmospheric Administration, 2005f, Flood of April 2005: Binghamton, N.Y., National Weather Service, accessed June 2005, at http://www.erh.noaa.gov/ bgm/WeatherEvents/Flood/april2005/.

National Oceanic and Atmospheric Administration, 2005g, North American Vertical Datum Conversion Utility: Silver Spring, Maryland, National Geodetic Survey, accessed November 2005, at http://www.ngs.noaa.gov/TOOLS/ Vertcon/vertcon.html.

Times Herald-Record, 2005a, Massive flooding: Middletown, N.Y., April 4.

Times Herald-Record, 2005b, Hundreds left homeless: Middletown, N.Y., April 6.

Times Herald-Record, 2005c, Flood Bill could be \$80M plus: Middletown, N.Y., April 7.
The River Reporter, 2005, Flood ravages valley: Narrowsburg, N.Y., April 7-13.

The Times Union, 2005, Flood victim found; emergencies declared: Albany, N.Y., April 6.

U.S. Geological Survey, 1960, Compilation of records of surface waters of the United States through September 1950, Part 1-B North Atlantic Slope Basins, New York to York River: U.S. Geological Survey Water-Supply Paper 1302, 679 p.

U.S. Geological Survey, 1964, Compilation of records of surface waters of the United States, October 1950 to September 1960, Part 1-B North Atlantic Slope Basins, New York to York River: U.S. Geological Survey Water-Supply Paper 1722,578 p.

U.S. Weather Bureau, 1961, Rainfall frequency atlas of the United States: Washington, D.C., Technical Paper no. 40, $115 \mathrm{p}$. 


\section{Appendix 1. Site Descriptions and High-Water Marks at Study Sites, Flood of April 2-3, 2005, in the Neversink River Basin, New York}

The term "quad map" in Appendix 1 refers to a USGS 7.5' Topographic Quadrangle Map.

High-water-marks listed in table 5 are shown on the maps in Appendix 1.

All horizontal location coordinates are referenced to the North American Datum of 1983

(NAD 83); lat, latitude; long, longitude. 
SITE DESCRIPTION

Site 1: Neversink River at USGS stream-gaging station 01436000 at Neversink, N.Y.

Site Location: USGS stream-gaging station 01436000 , lat $41^{\circ} 49^{\prime} 12^{\prime \prime}$, long $74^{\circ} 38^{\prime} 08^{\prime \prime}$, NAD 83

Town of Neversink, Sullivan County, N.Y.

Liberty East USGS 7.5' Topographic Quadrangle

High-Water Marks: Seven high-water marks were surveyed: seven debris lines.

Photos and GPS readings were taken at each high-water mark. Field notes are filed at the USGS office in Troy, N.Y.

Marks were surveyed and photos taken by T.P. Suro and K.D. Reisig on June 9, 2005.

High-water-mark elevations were surveyed from a reference mark that is the USGS stream-gaging station 01436000 reference mark RM 4. Elevation is 1,286.01 feet above NGVD 29. To convert to NAVD 88, subtract 0.57 feet from all elevations at this site.

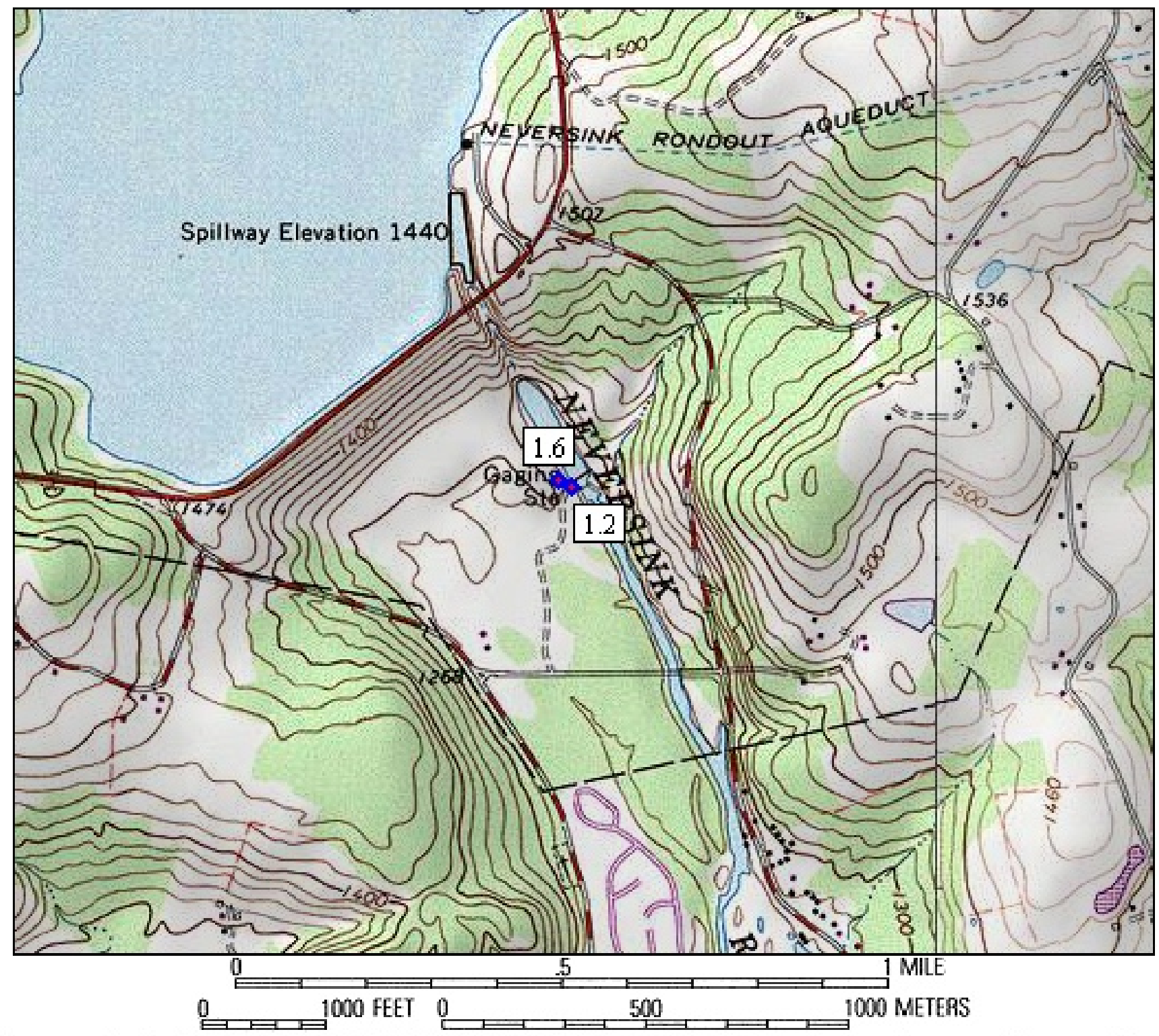

Map created with TOPO!(B) (02003 National Geographic (www.nationalgeographic.com/topo)

Liberty East quad map with location of site 1, Neversink River at USGS stream-gaging station 01436000 at Neversink, N.Y. 


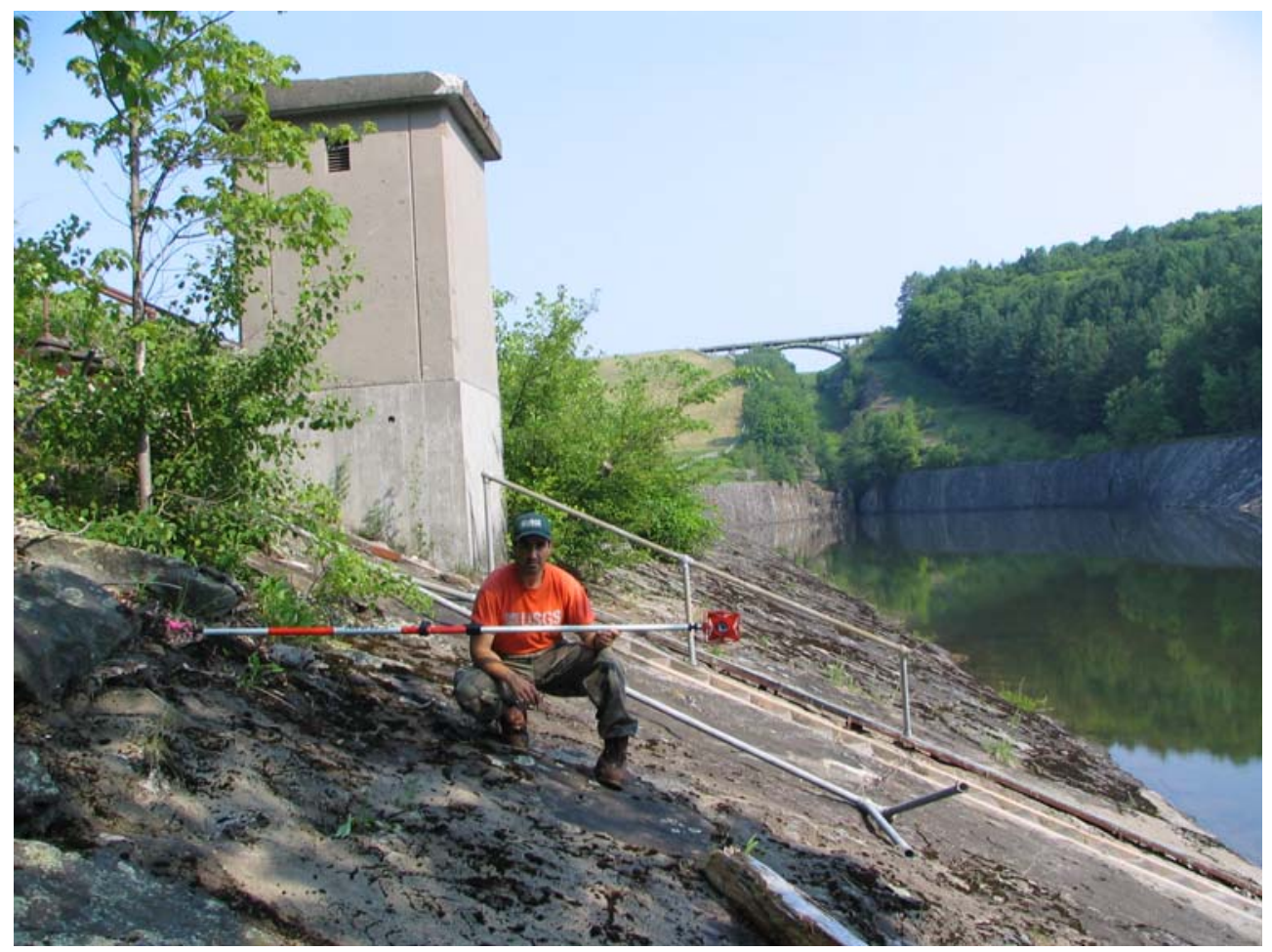

High-water mark 1.2 is a poor debris line on the ground, on the right bank, 50 feet downstream from the USGS stream-gaging station 01436000 , at elevation 1,268.70 feet above NGVD 29 (lat $41^{\circ} 49^{\prime} 12.5^{\prime \prime}$, long $74^{\circ} 38^{\prime} 07.5^{\prime \prime}$ ).

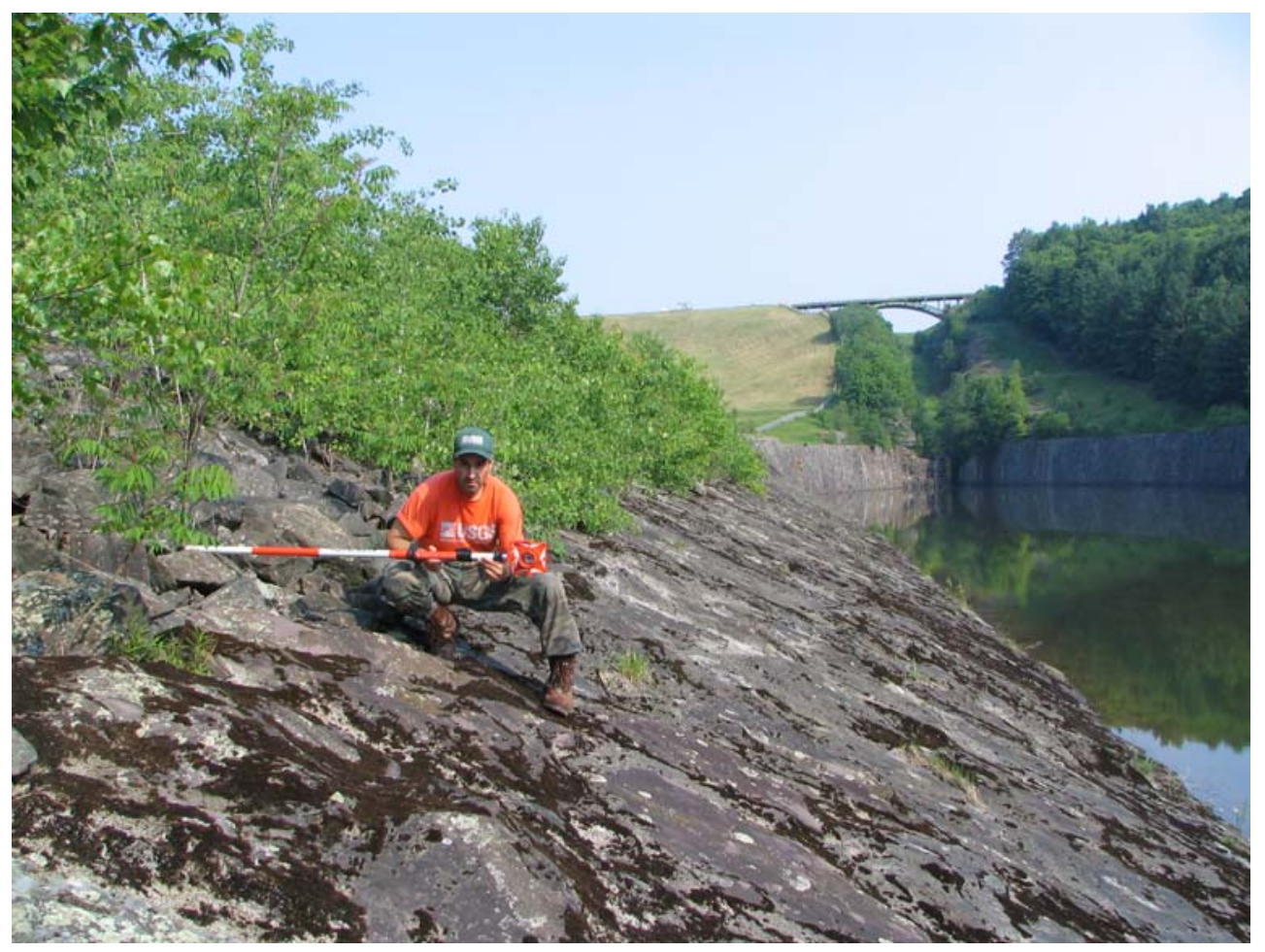

High-water mark 1.6 is a poor debris line on the ground, on the right bank, 40 feet upstream from the USGS stream-gaging station, at elevation 1,270.67 feet above NGVD 29 (lat $41^{\circ} 49^{\prime} 13.1^{\prime \prime}$, long $74^{\circ} 38^{\prime} 08.8^{\prime \prime}$ ). 
SITE DESCRIPTION

Site 2: Neversink River at BWS Road near Neversink, N.Y.

Site Location: Bridge on BWS Road, lat $41^{\circ} 48$ 57.9”, long $74^{\circ} 37^{\prime} 56.9^{\prime \prime}$, NAD 83

Town of Neversink, Sullivan County, N.Y.

Liberty East USGS 7.5' Topographic Quadrangle

High-Water Marks: Seven high-water marks were surveyed: seven debris lines.

Photos and GPS readings were taken at each high-water mark. Field notes are filed at the USGS office in Troy, N.Y.

Marks were surveyed and photos taken by T.P. Suro and K.D. Reisig on June 9, 2005.

High-water-mark elevations were surveyed from a reference mark that is the USGS stream-gaging station 01436000 reference mark RM 4. Elevation is 1,286.01 feet above NGVD 29. To convert to NAVD 88, subtract 0.57 feet from all elevations at this site.

Thalweg Elevation: 1,242.4 feet above NGVD 29.

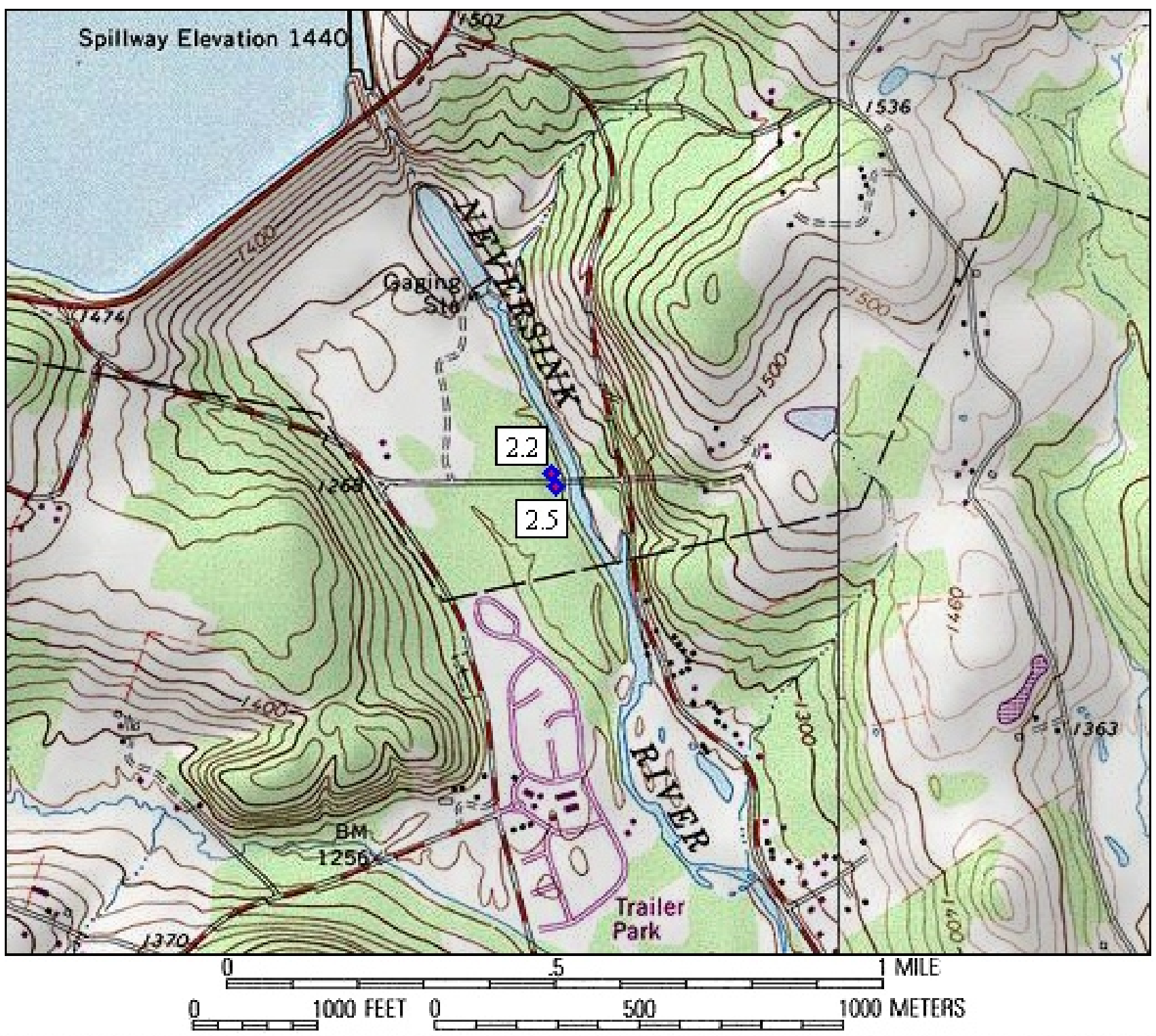

Map created with TOPO!(B) (02003 National Geographic (www.nationalgeographic.com/topo)

Liberty East quad map with location of site 2, Neversink River at BWS Road near Neversink, N.Y. 


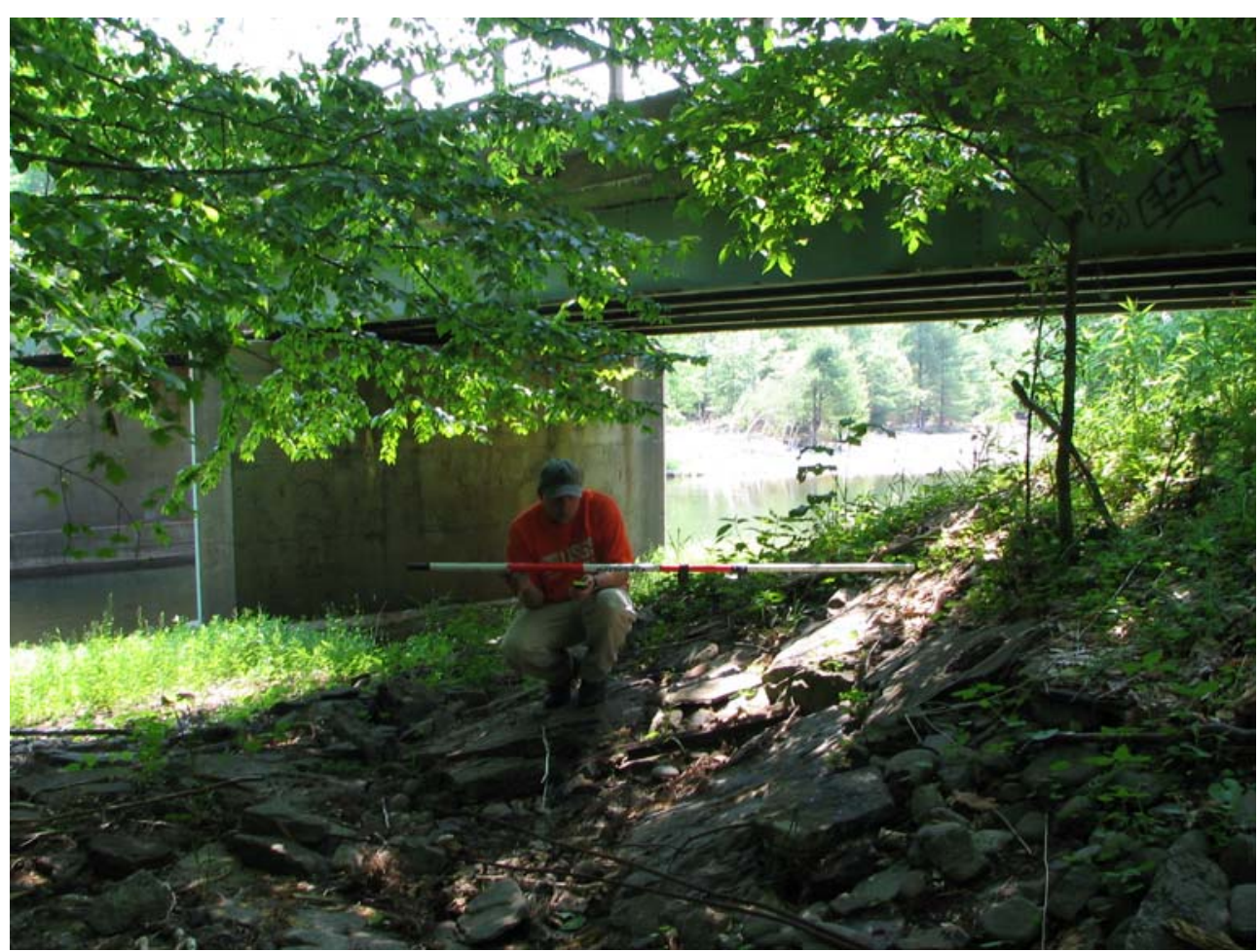

High-water mark 2.2 is a fair debris line on the ground, on the right bank, 20 feet upstream from the BWS Road bridge, at elevation 1,262.30 feet above NGVD 29 (lat $41^{\circ} 48^{\prime} 58.3^{\prime \prime}$, long $\left.74^{\circ} 37^{\prime} 58.9^{\prime \prime}\right)$.

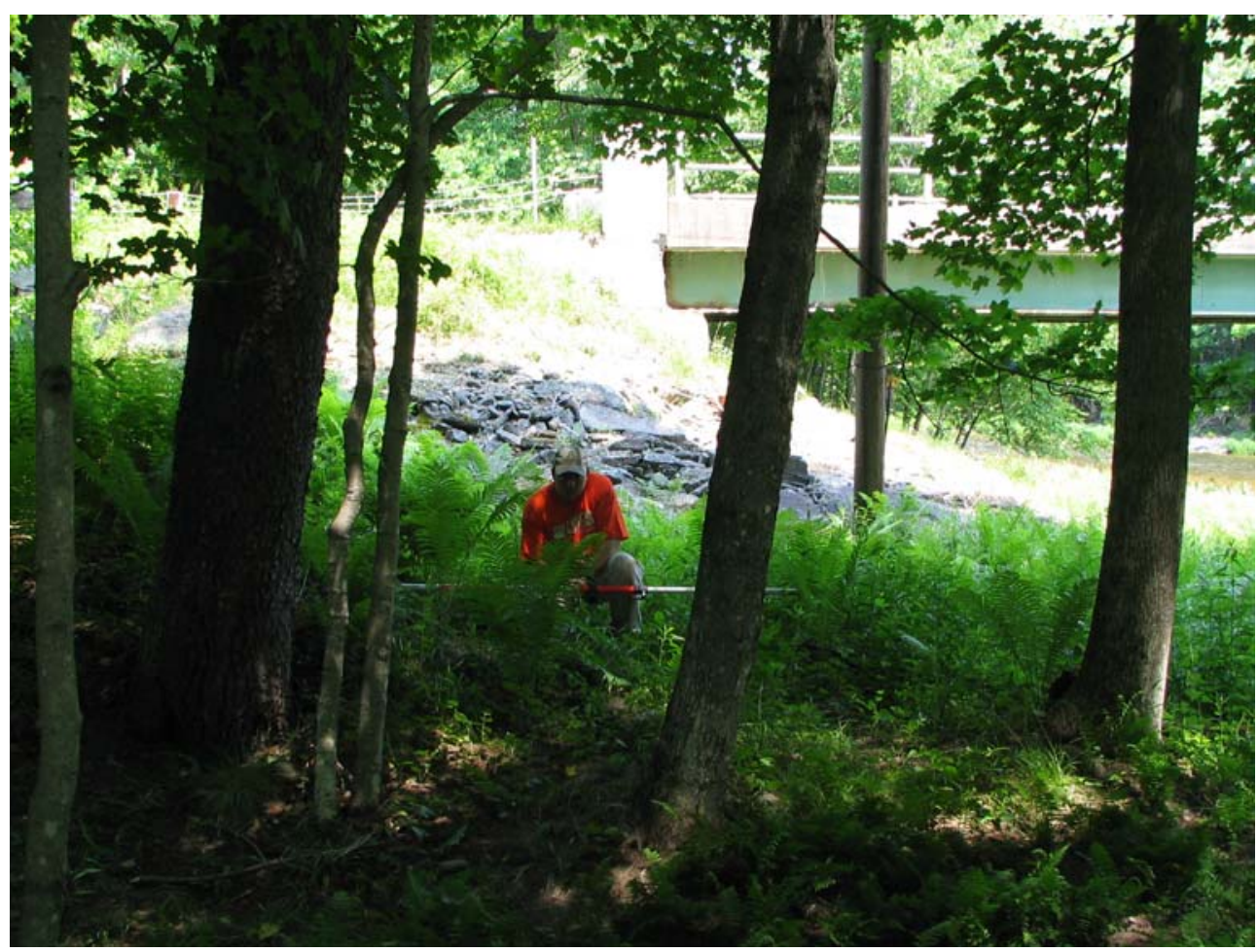

High-water mark 2.5 is a fair debris line on the ground, on the right bank, 40 feet downstream from the BWS Road bridge, at elevation 1,261.53 feet above NGVD 29 (lat $41^{\circ} 48^{\prime} 57.3$ ”, long $74^{\circ} 37^{\prime} 58.6^{\prime \prime}$ ). 
SITE DESCRIPTION

Site 3: Neversink River at Hasbrouck A Road at Hasbrouck, N.Y.

Site Location: Bridge on Hasbrouck A Road, lat $41^{\circ} 47^{\prime} 16.9^{\prime \prime}$, long $74^{\circ} 36^{\prime} 56.0^{\prime \prime}$, NAD 83

Town of Fallsburg, Sullivan County, N.Y.

Grahamsville USGS 7.5' Topographic Quadrangle

High-Water Marks: Five high-water marks were surveyed: five debris lines.

Photos and GPS readings were taken at each high-water mark. Field notes are filed at the USGS office in Troy, N.Y.

Marks were surveyed and photos taken by T.P. Suro and K.D. Reisig on June 8, 2005.

High-water-mark elevations were surveyed from a benchmark that is a USGS standard disk stamped 12FHK1961-1243 set in top of 8-foot-diameter boulder 2.3 miles north of post office along Hasbouck A Road and 100 feet west of road (disk is in yard of house 481). Elevation is 1,242.53 feet above NGVD 29. To convert to NAVD 88, subtract 0.59 feet from all elevations at this site.

Thalweg Elevation: 1,200.3 feet above NGVD 29.

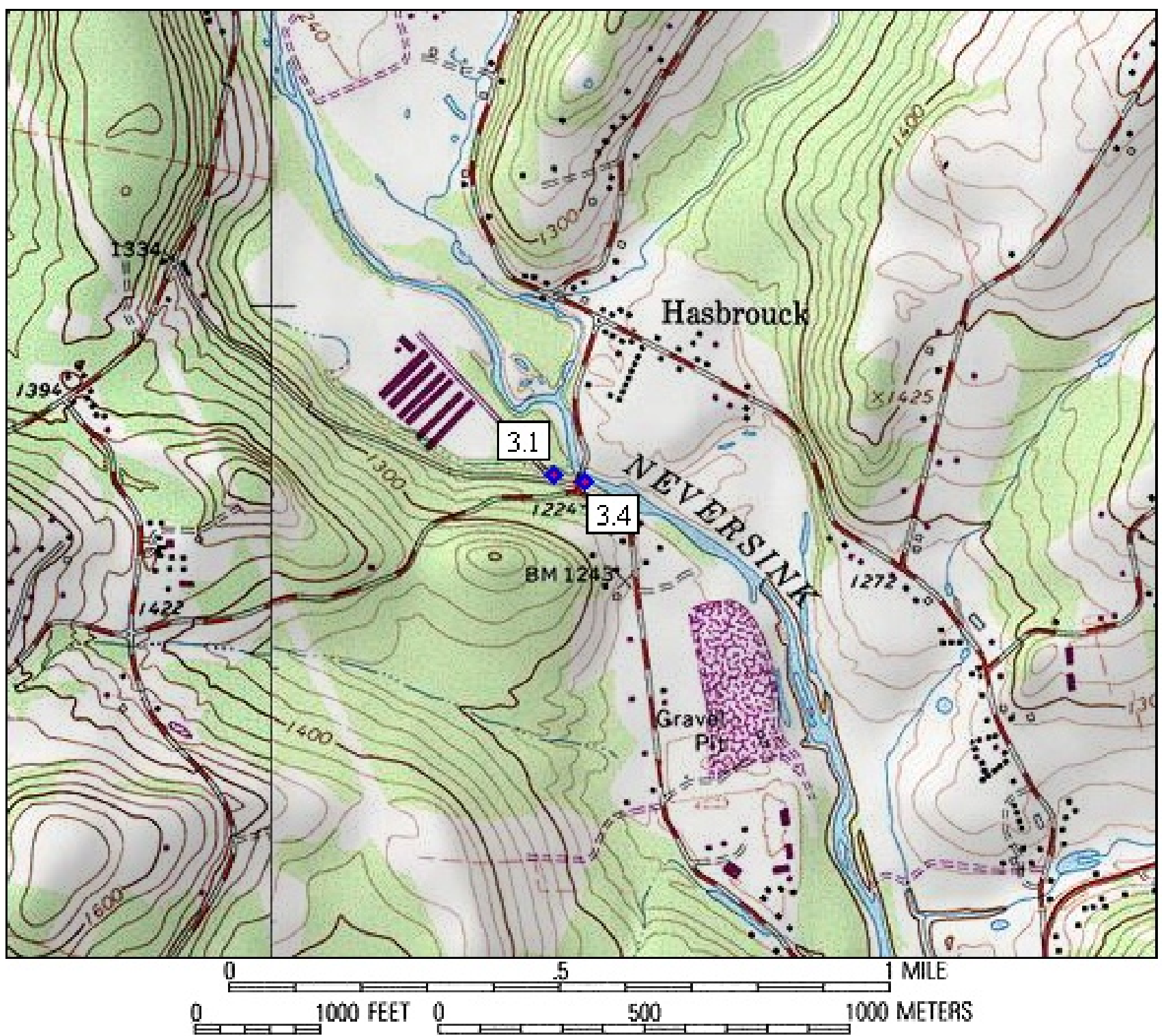

Map created with TOPO!(B) (02003 National Geographic (www nationalgeographic.com/topo)

Grahamsville quad map with location of site 3, Neversink River at Hasbrouck A Road at Hasbrouck, N.Y. 


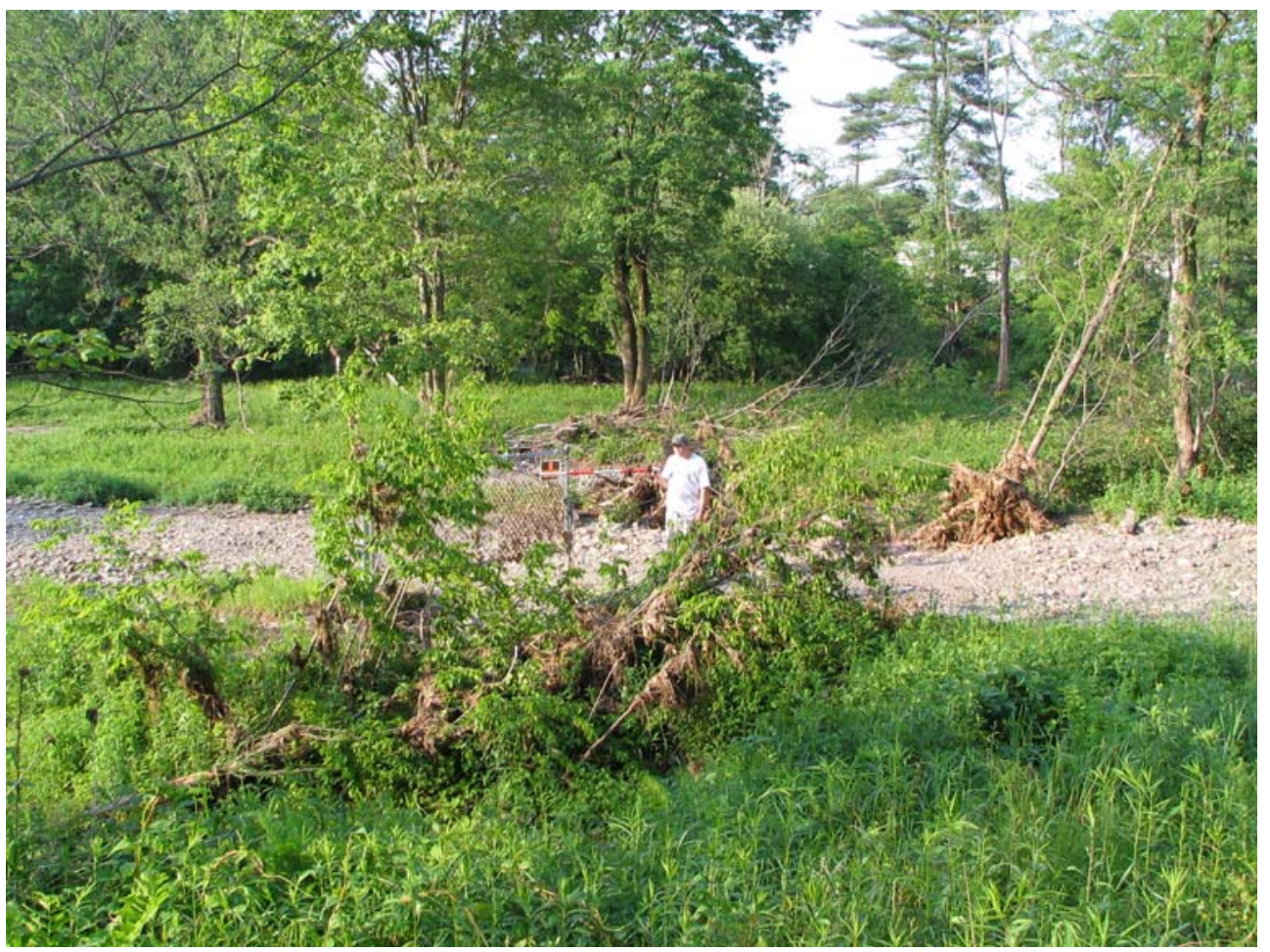

High-water mark 3.1 is a fair debris line 4.4 feet above the ground, on the side of a metal fence on the right bank, 170 feet

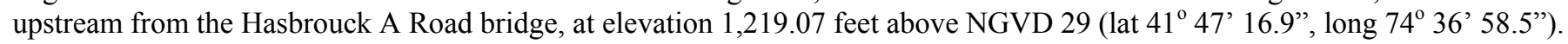

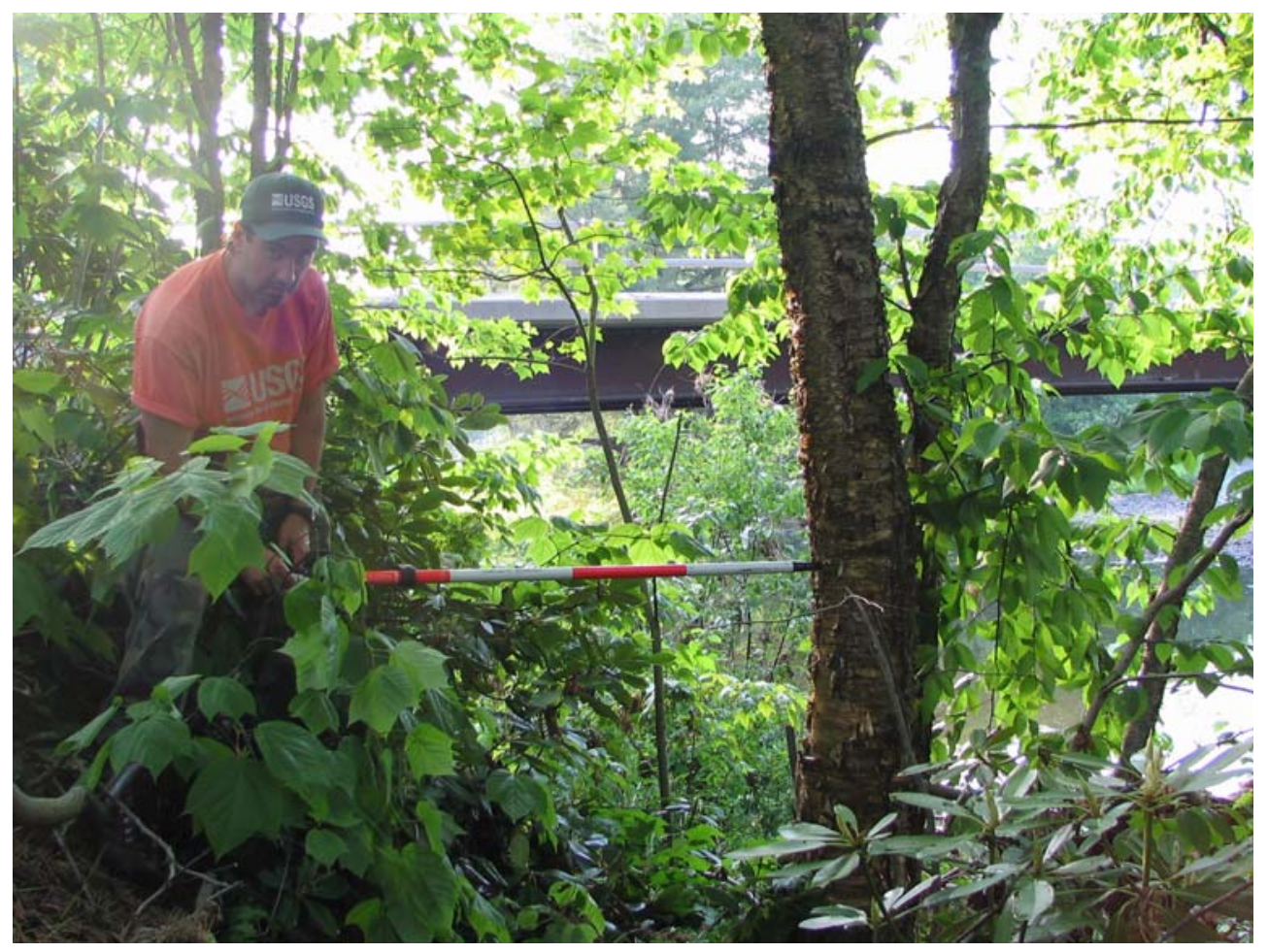

High-water mark 3.4 is a fair debris line 3.6 feet above the ground, on a tree on the right bank, 40 feet downstream from the

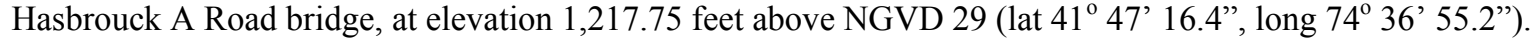


SITE DESCRIPTION

Site 4: Neversink River at State Routes 42 and 52 at Woodbourne, N.Y.

Site Location: Bridge on State Routes 42 and 52, lat $41^{\circ} 45^{\prime} 35.6$ ”, long $74^{\circ} 35^{\prime}$ 58.5”, NAD 83

Town of Fallsburg, Sullivan County, N.Y.

Grahamsville USGS 7.5' Topographic Quadrangle

High-Water Marks: Four high-water marks were surveyed: four debris lines.

Photos and GPS readings were taken at each high-water mark. Field notes are filed at the USGS office in Troy, N.Y. Marks were surveyed and photos taken by T.P. Suro and K.D. Reisig on June 8, 2005.

High-water-mark elevations were surveyed from a benchmark that is a USGS standard disk stamped 11FHK1961-RESET

1982 set in the northwest end of southwest concrete bridge abutment of the State Routes 42 and 52 bridge. Elevation is

1,189.55 feet above NGVD 29, from NYS DOT bridge plans, BIN 1024990. To convert to NAVD 88, subtract 0.60 feet from all elevations at this site.

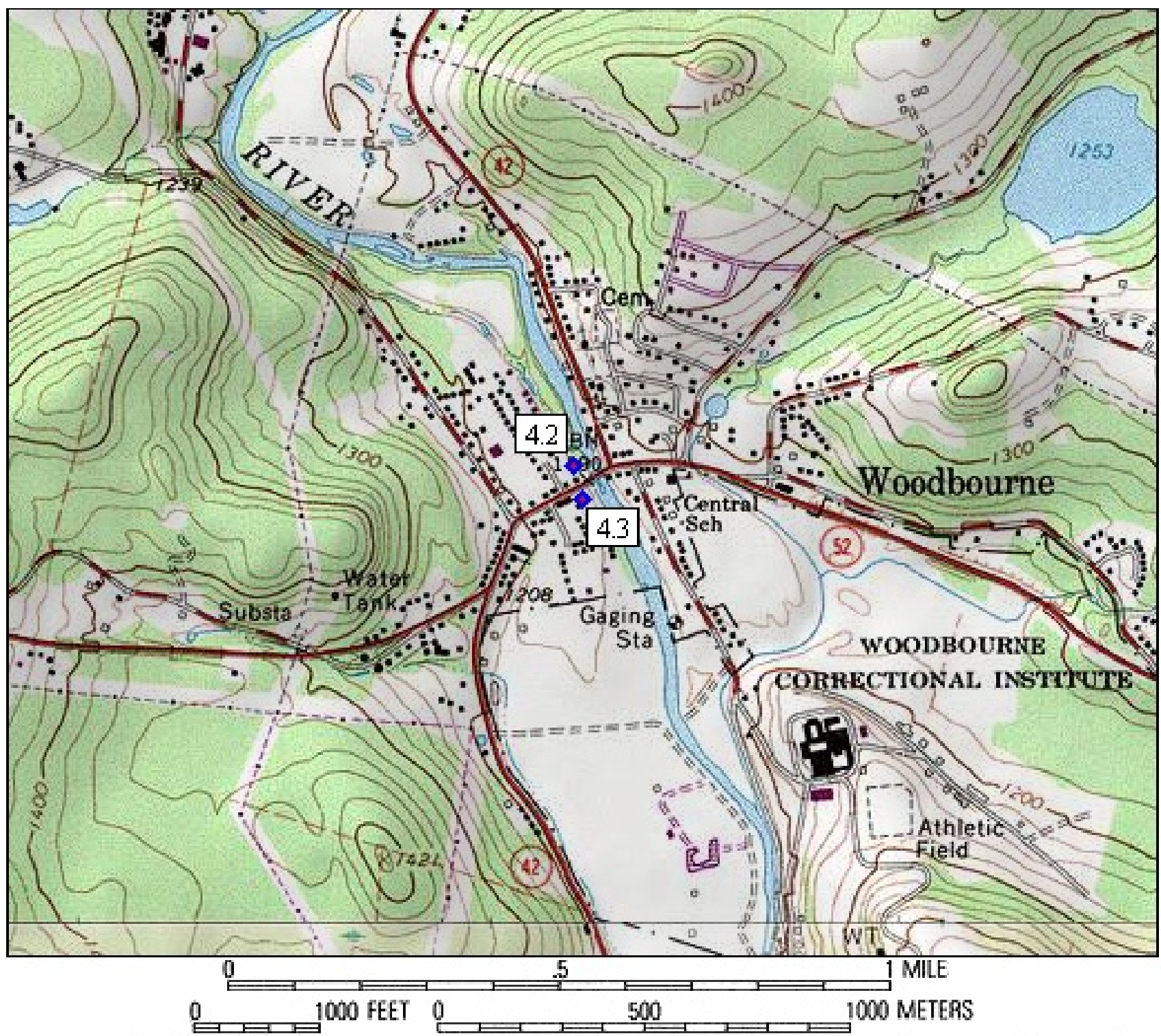

Map created with TOPO!( (]2003 National Geographic (www nationalgeographic.com/topo)

Grahamsville quad map with location of site 4, Neversink River at State Routes 42 and 52 at Woodbourne, N.Y. 


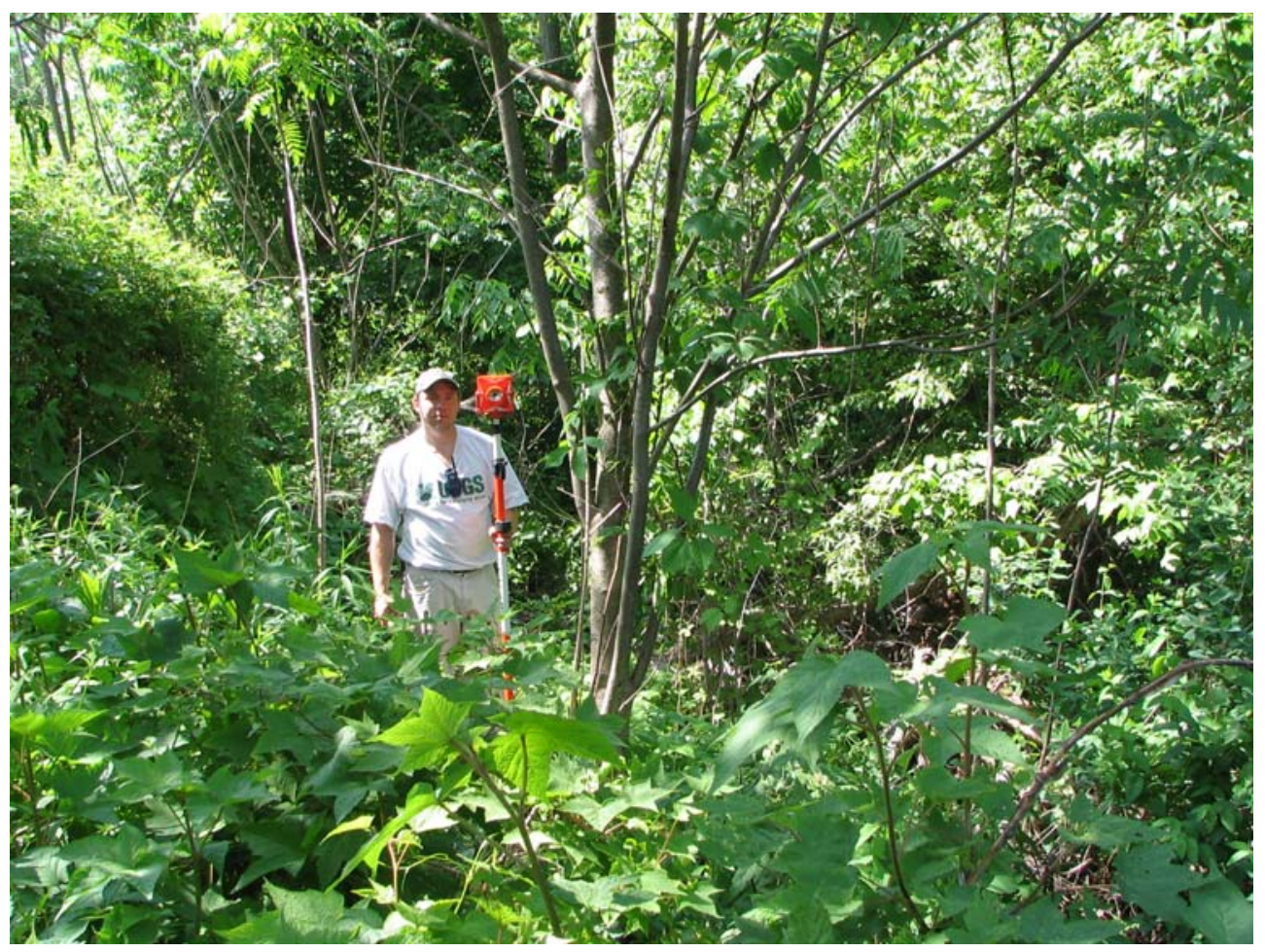

High-water mark 4.2 is a poor debris line on the ground, on the right bank, 120 feet upstream from the State Routes 42 and 52 bridge, at elevation 1,182.00 feet above NGVD 29 (lat $41^{\circ} 45^{\prime} 36.4^{\prime \prime}$, long $74^{\circ} 36^{\prime} 00.6^{\prime \prime}$ ).

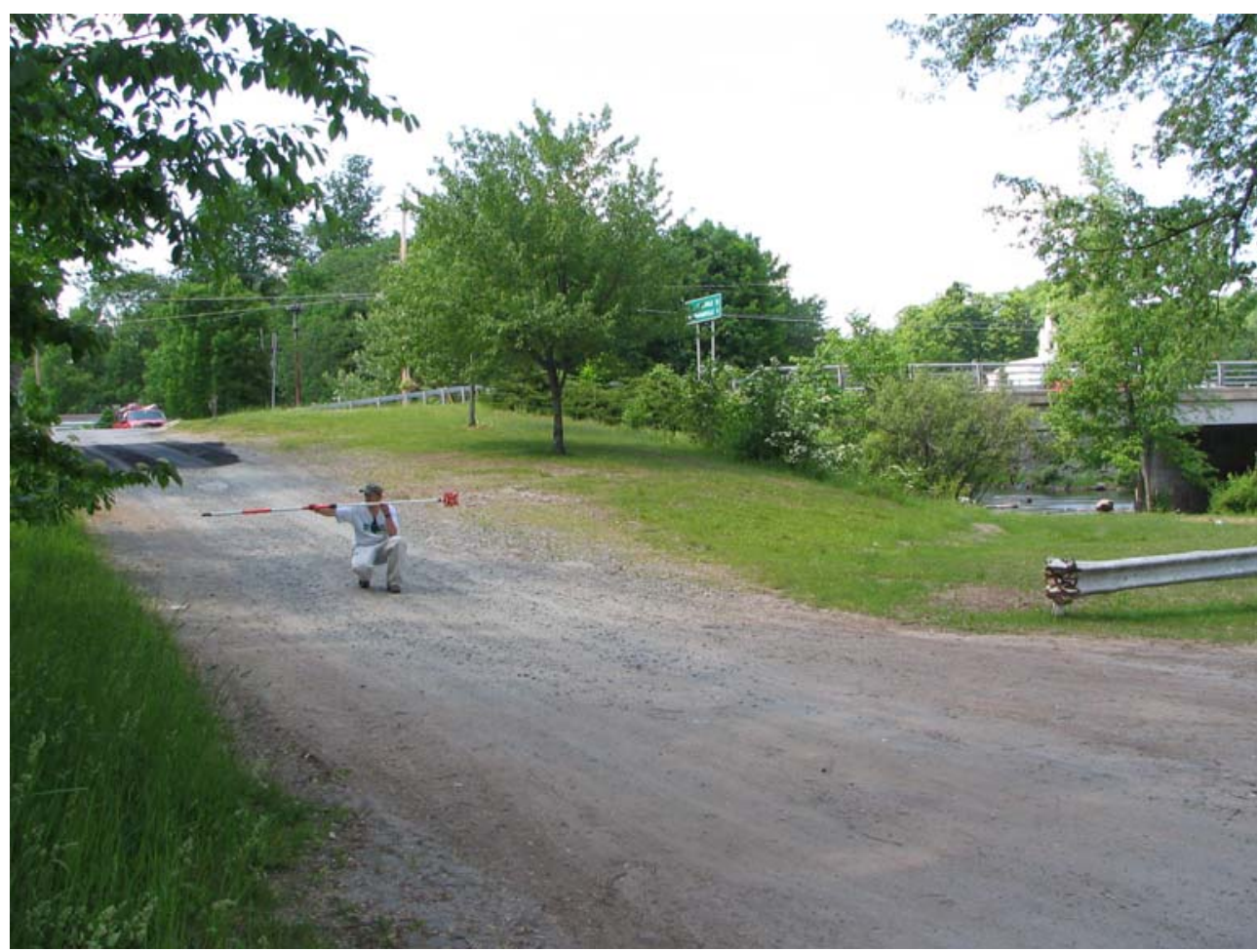

High-water mark 4.3 is a fair debris line on remains of old concrete wall, on the right bank, 120 feet downstream from the State Routes 42 and 52 bridge, at elevation 1,181.48 feet above NGVD 29 (lat $41^{\circ} 45^{\prime} 33.7^{\prime \prime}$, long $74^{\circ} 35^{\prime} 59.8^{\prime \prime}$ ). 
SITE DESCRIPTION

Site 5: Neversink River at USGS stream-gaging station 01436500 at Woodbourne, N.Y.

Site Location: USGS stream-gaging station 04365000 (discontinued), lat $41^{\circ} 45^{\prime} 24.0^{\prime \prime}$, long $74^{\circ} 35^{\prime} 49.8^{\prime \prime}$, NAD 83

Town of Fallsburg, Sullivan County, N.Y.

Grahamsville USGS 7.5' Topographic Quadrangle

High-Water Marks: Eight high-water marks were surveyed: eight debris lines.

Photos and GPS readings were taken at each high-water mark. Field notes are filed at the USGS office in Troy, N.Y.

Marks were surveyed and photos taken by T.P. Suro and K.D. Reisig on June 8, 2005.

High-water-mark elevations were surveyed from a benchmark that is a USGS standard disk stamped 11FHK1961-RESET

1982 set in the northwest end of southwest concrete bridge abutment of the State Routes 42 and 52 bridge. Elevation is

1,189.55 feet above NGVD 29, from NYS DOT bridge plans, BIN 1024990. To convert to NAVD 88, subtract 0.60 feet from all elevations at this site.

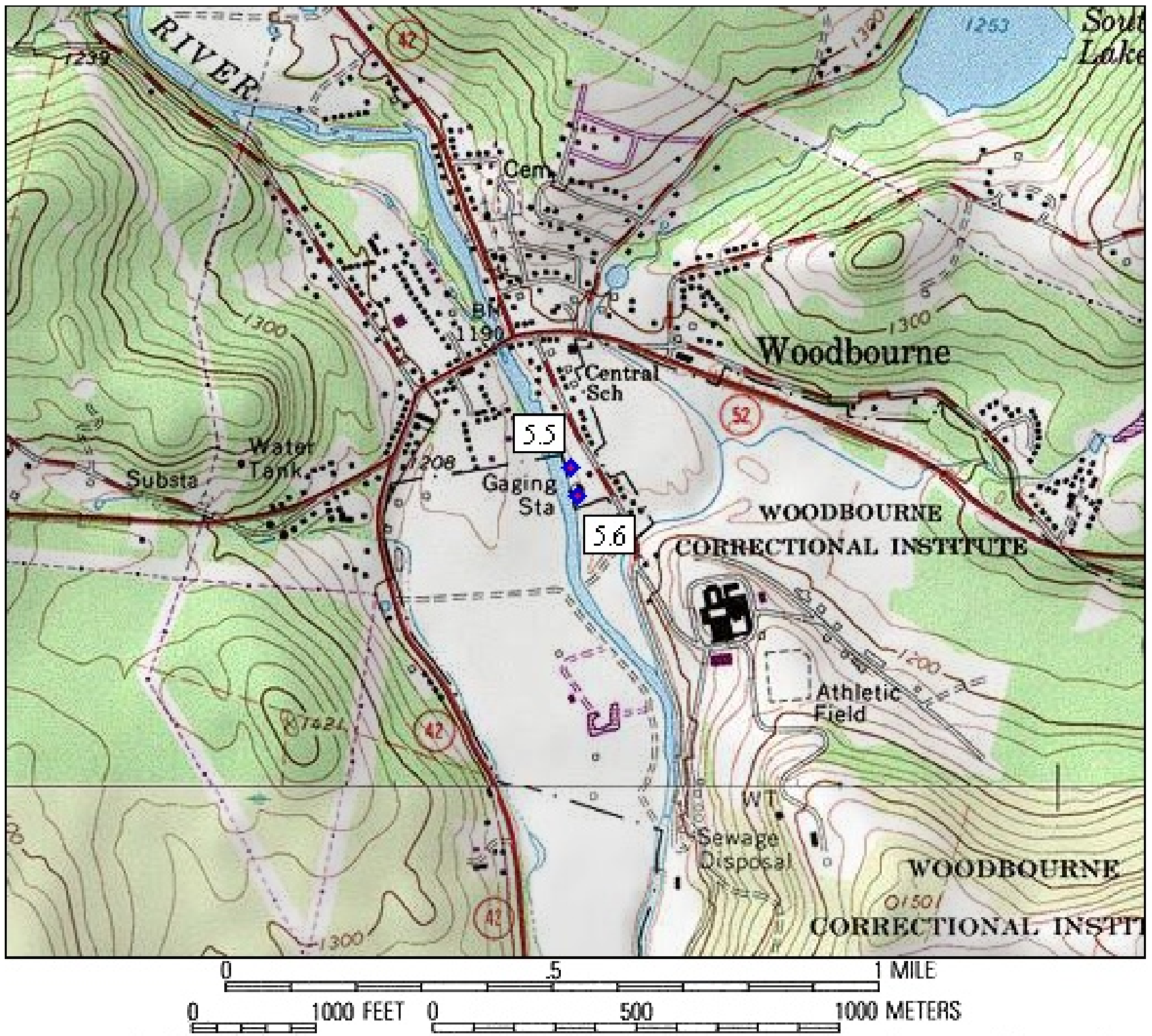

Map created with TOPO!( (02003 National Geographic (www nationalgeographic.com/topo)

Grahamsville quad map with location of site 5, Neversink River at USGS stream-gaging station 01436500 at Woodbourne, N.Y. 


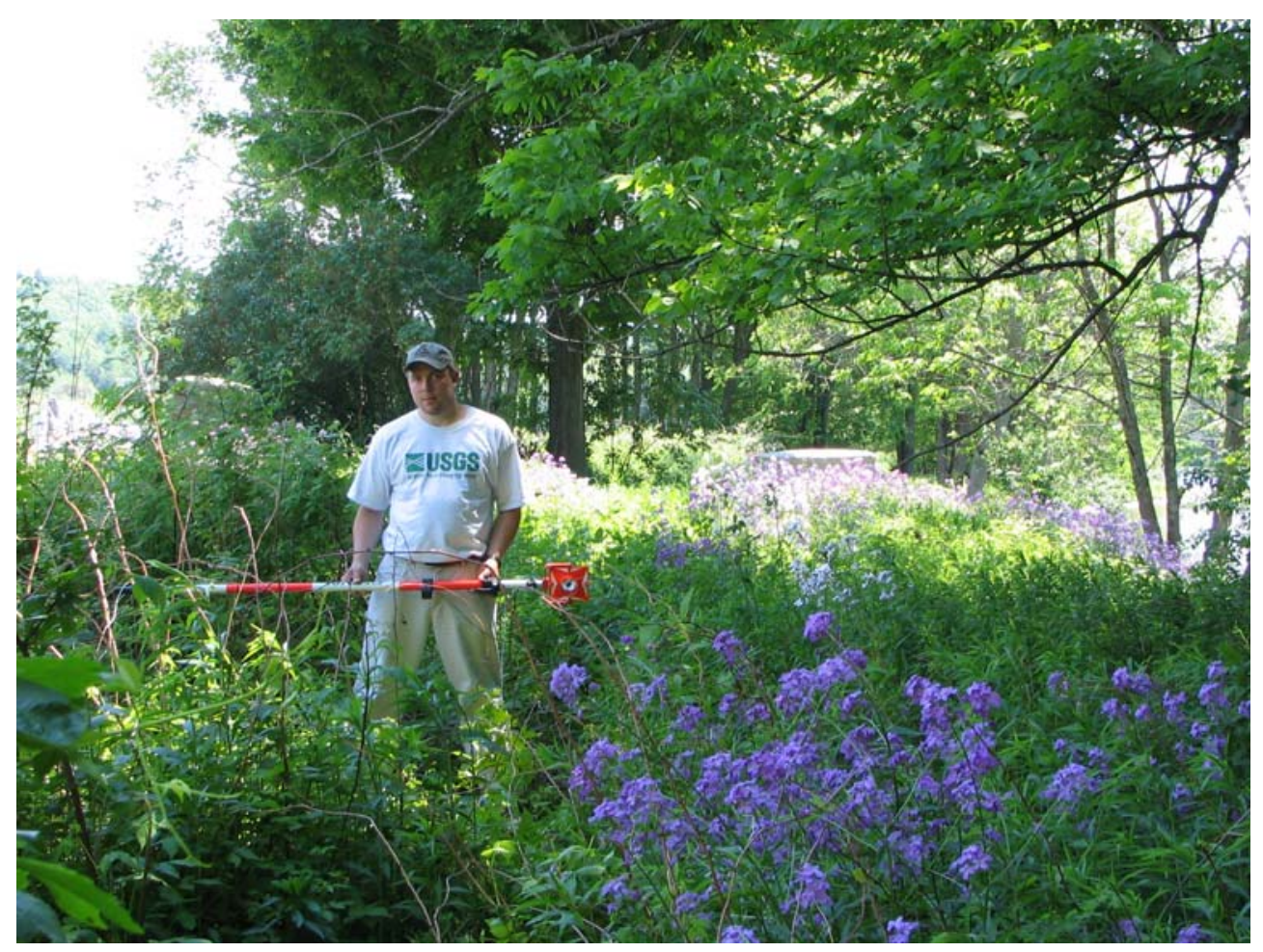

High-water mark 5.5 is a fair debris line on the ground, on the left bank, 170 feet upstream from the USGS stream-gaging station, at elevation 1,179.24 feet above NGVD 29 (lat $41^{\circ} 45^{\prime} 25.8^{\prime \prime}$, long $74^{\circ} 35^{\prime} 50.5^{\prime \prime}$ ).

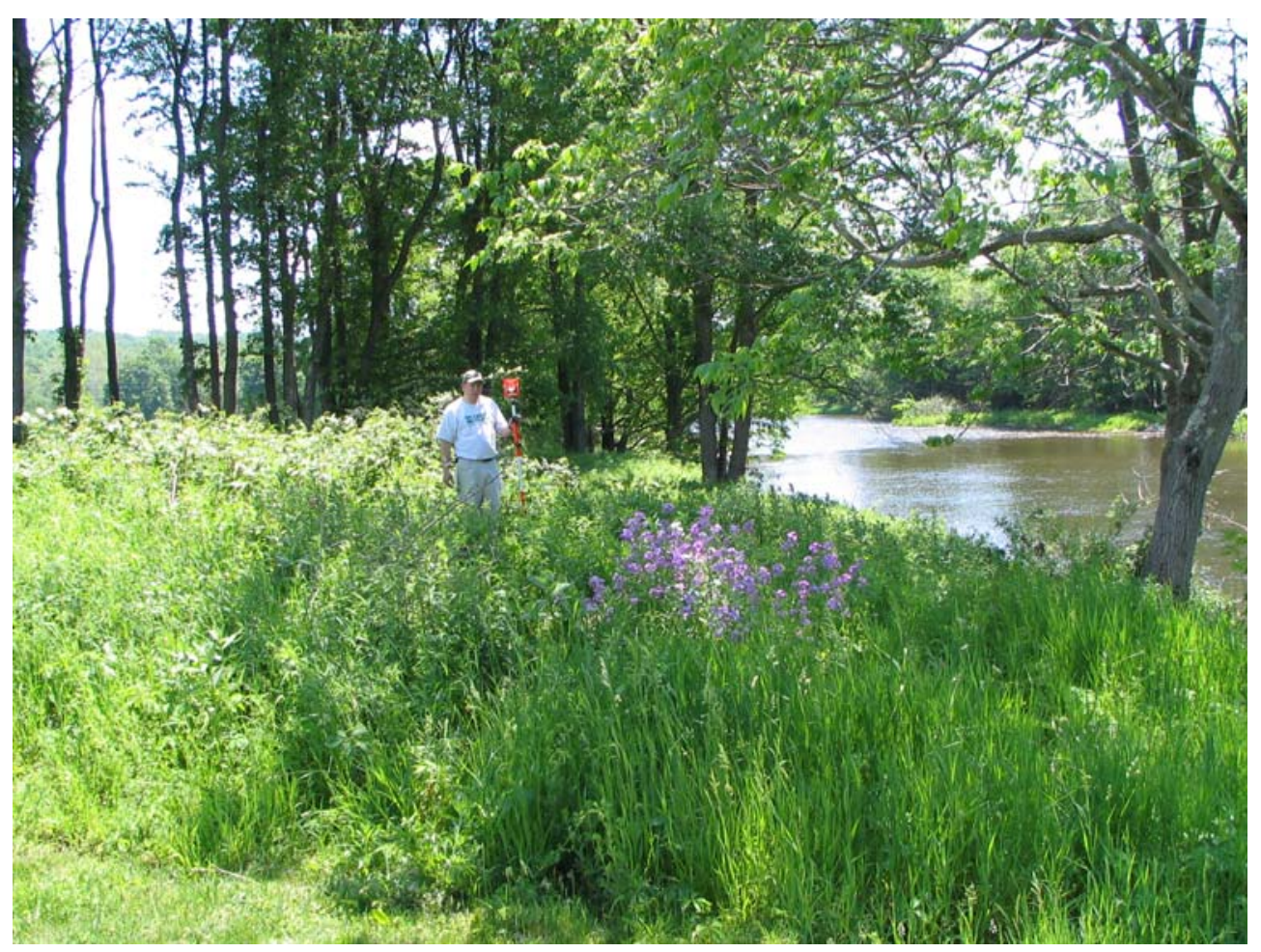

High-water mark 5.6 is a fair debris line on the ground, on the left bank, 42 feet downstream from the USGS stream-gaging station, at elevation 1,178.83 feet above NGVD 29 (lat $41^{\circ} 45^{\prime} 23.6^{\prime \prime}$, long $74^{\circ} 35^{\prime} 49.8^{\prime \prime}$ ). 


\begin{tabular}{|c|}
\hline SITE DESCRIPTION \\
\hline Site 6: Neversink River at County Route 53 at Fallsburg, N.Y. \\
\hline Site Location: Bridge on County Route 53, lat $41^{\circ} 43^{\prime} 49.1^{\prime \prime}$, long $74^{\circ} 36^{\prime} 14.0^{\prime \prime}$, NAD 83 \\
\hline Town of Fallsburg, Sullivan County, N.Y. \\
\hline Woodridge USGS 7.5' Topographic Quadrangle \\
\hline High-Water Marks: Five high-water marks were surveyed: five debris lines. \\
\hline Photos and GPS readings were taken at each high-water mark. Field notes are filed at the USGS office in Troy, N.Y. \\
\hline Marks were surveyed and photos taken by T.P. Suro and K.D. Reisig on June 8, 2005. \\
\hline $\begin{array}{l}\text { High-water-mark elevations were surveyed from a benchmark that is a USGS standard disk stamped 10FHK1961-1243 set in } \\
\text { west end of south sidewalk of County Route } 53 \text { bridge. Elevation is } 1,162.33 \text { feet above NGVD 29. To convert to NAVD } 88 \text {, } \\
\text { subtract } 0.61 \text { feet from all elevations at this site. }\end{array}$ \\
\hline
\end{tabular}

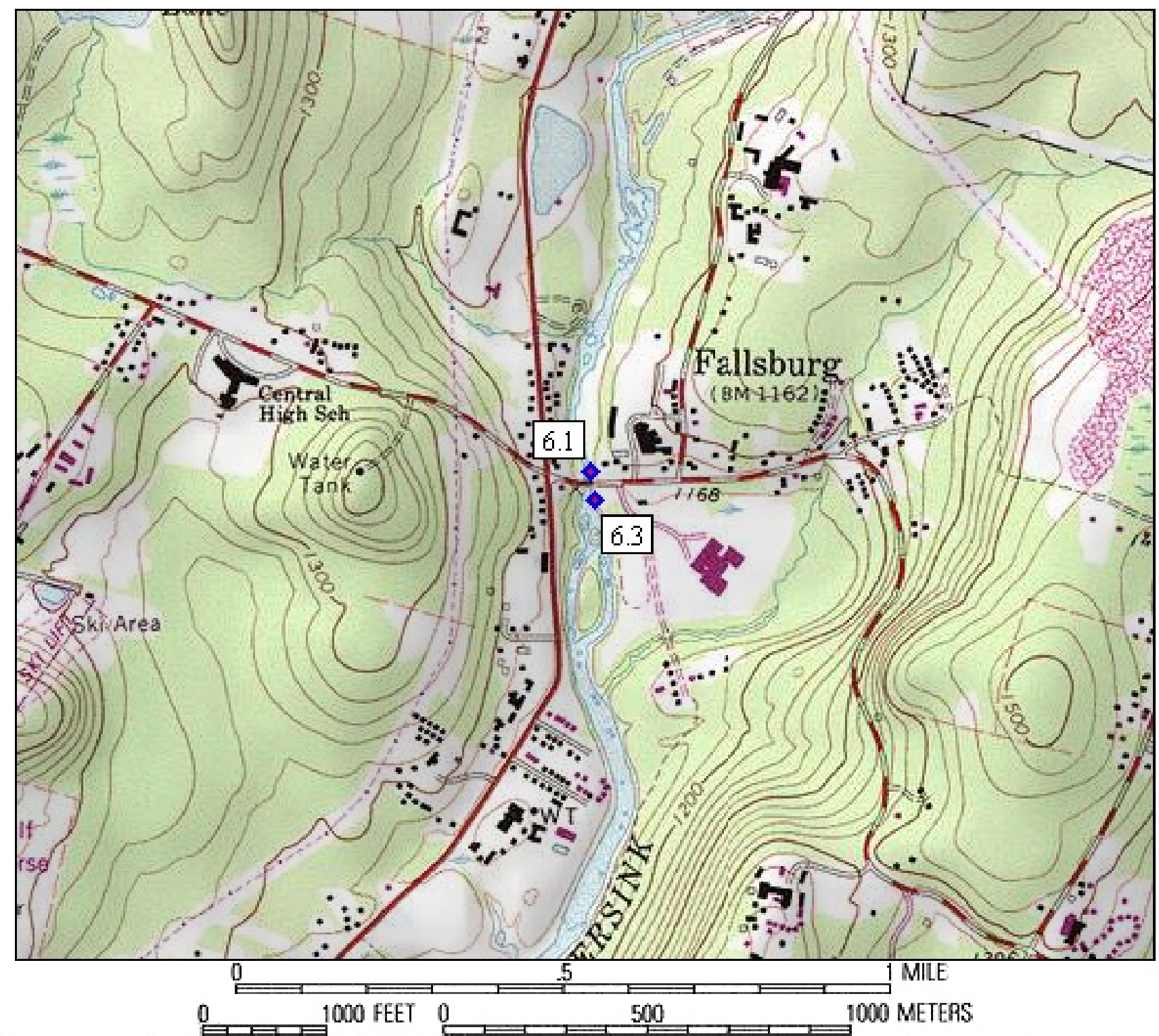

Map created with TOPO!() (02003 National Geographic (www nationalgeographic.com/topo)

Woodridge quad map with location of site 6, Neversink River at County Route 53 at Fallsburg, N.Y. 


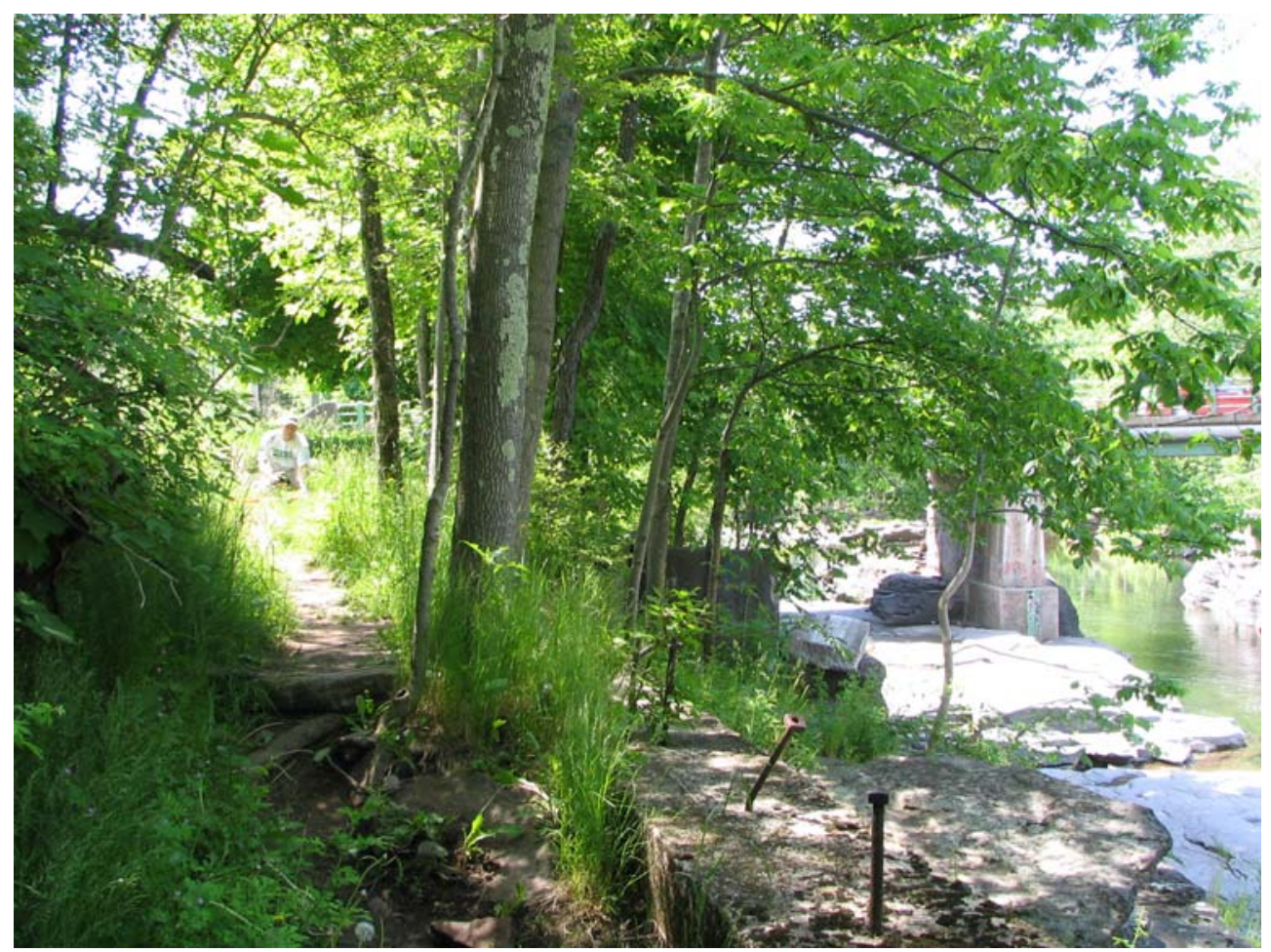

High-water mark 6.1 is a fair debris line on the ground, on the left bank, 69 feet upstream from the County Route 53 bridge, at elevation $1,155.93$ feet above NGVD 29 (lat $41^{\circ} 43^{\prime} 50.0^{\prime \prime}$, long $74^{\circ} 36^{\prime} 13.3^{\prime \prime}$ ).

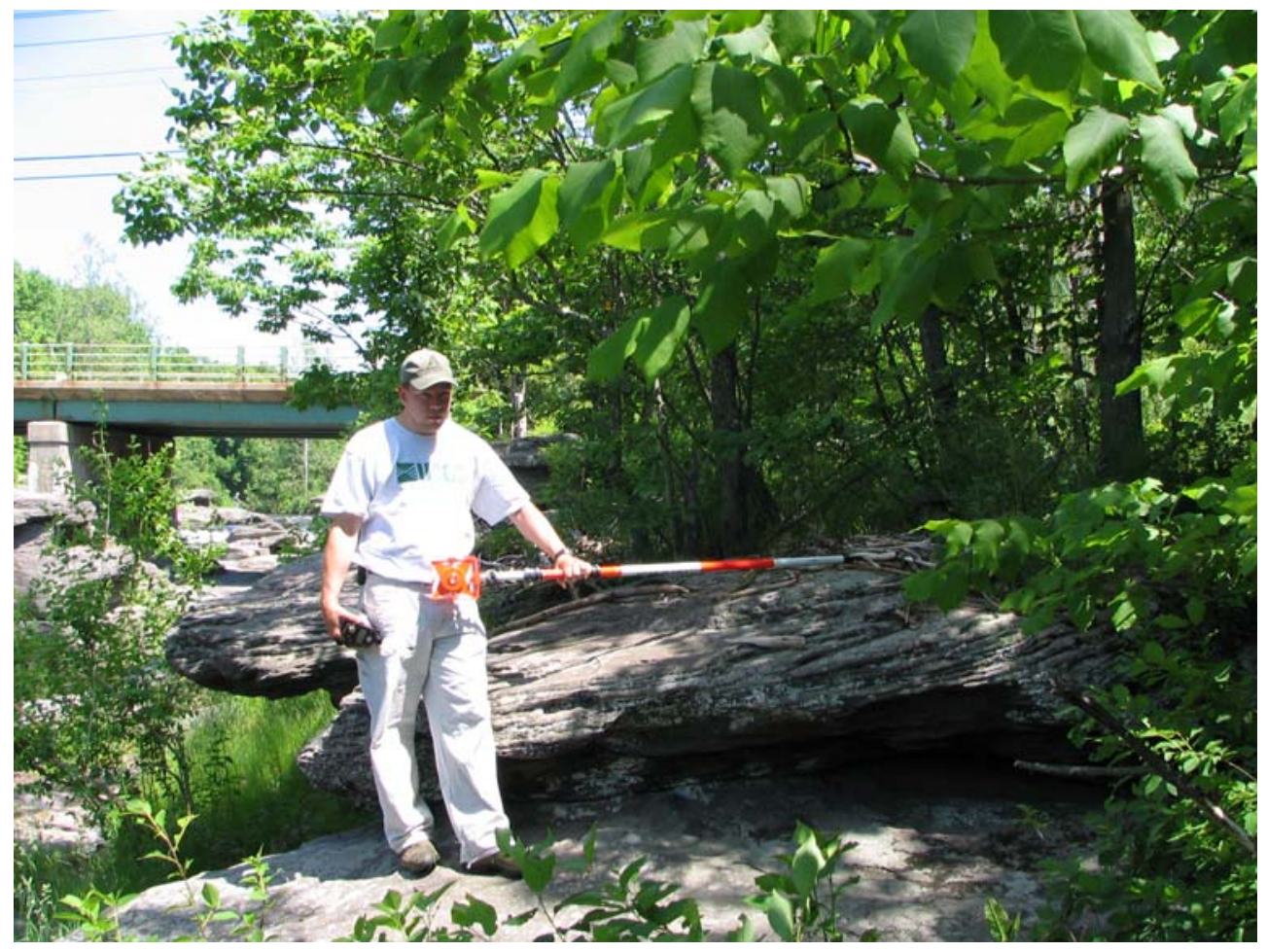

High-water mark 6.3 is a fair debris line on the ground, on the left bank, 110 feet downstream from the County Route 53 bridge, at elevation 1,149.23 feet above NGVD 29 (lat 41 ${ }^{\circ} 43^{\prime} 47.7^{\prime \prime}$, long $74^{\circ} 36^{\prime} 13.0^{\prime \prime}$ ). 
SITE DESCRIPTION

Site 7: Neversink River at Ranch Hill Road near Thompsonville, N.Y.

Site Location: Bridge on Ranch Hill Road, lat $41^{\circ} 40^{\prime} 39.3^{\prime \prime}$, long $74^{\circ} 35^{\prime}$ 53.9”, NAD 83

Town of Thompson, Sullivan County, N.Y.

Woodridge USGS 7.5' Topographic Quadrangle

High-Water Marks: Five high-water marks were surveyed: five debris lines.

Photos and GPS readings were taken at each high-water mark. Field notes are filed at the USGS office in Troy, N.Y.

Marks were surveyed and photos taken by T.P. Suro and T.F. Hoffman on June 3, 2005.

High-water-mark elevations were surveyed from a benchmark that is a USGS standard disk stamped 39 FHK1961-1435 set in top of north corner of boulder, 0.2 miles north of Old Glenwild Road along Glenwild Road (County Route 58) and 24 feet west of the centerline of road. Elevation is $1,434.72$ feet above NGVD 29. To convert to NAVD 88, subtract 0.61 feet from all elevations at this site.

Thalweg Elevation: 1,080.1 feet above NGVD 29.

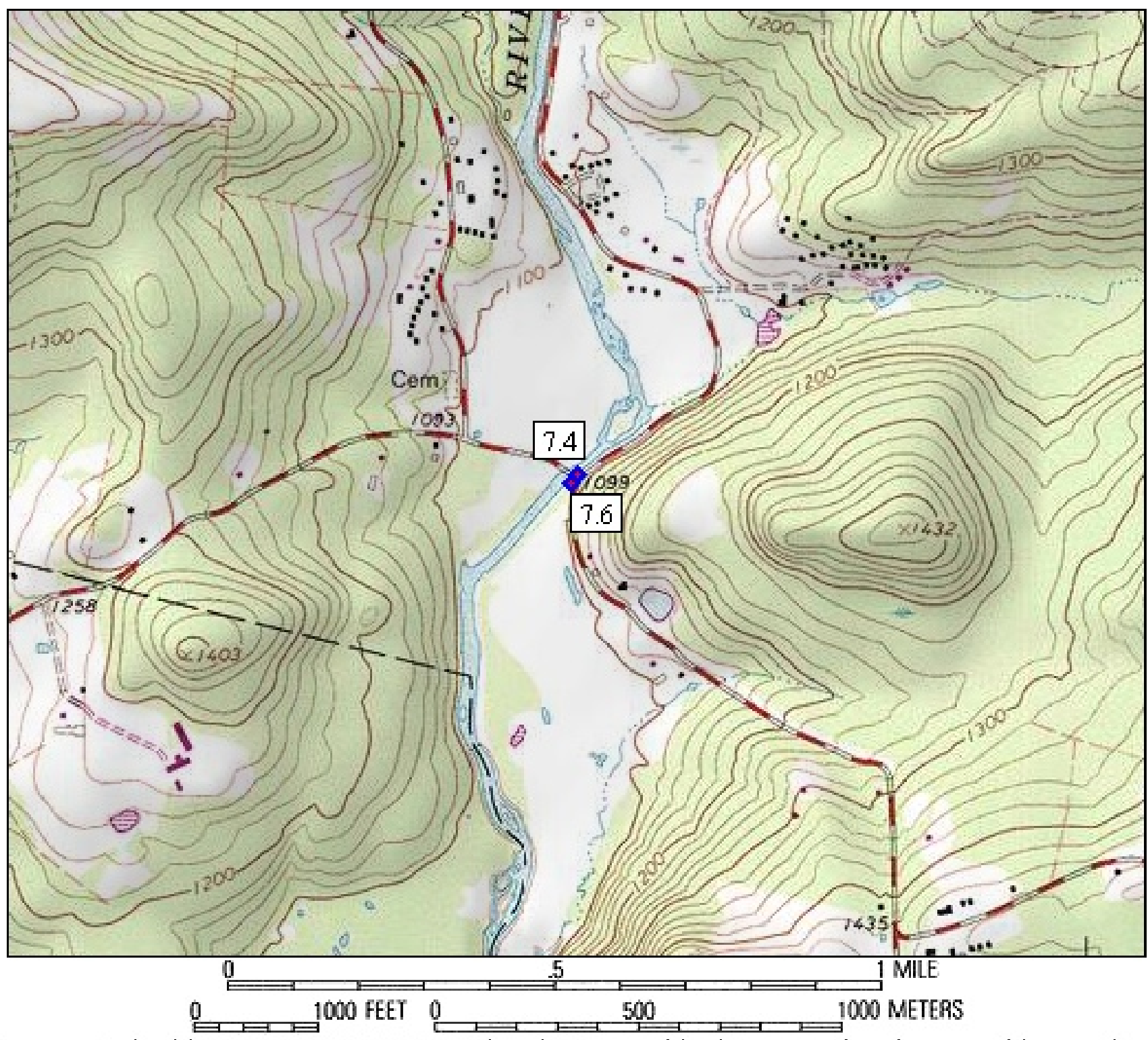

Map created with TOPO!(B) (02003 National Geographic (www.nationalgeographic.com/topo)

Woodridge quad map with location of site 7, Neversink River at Ranch Hill Road near Thompsonville, N.Y. 


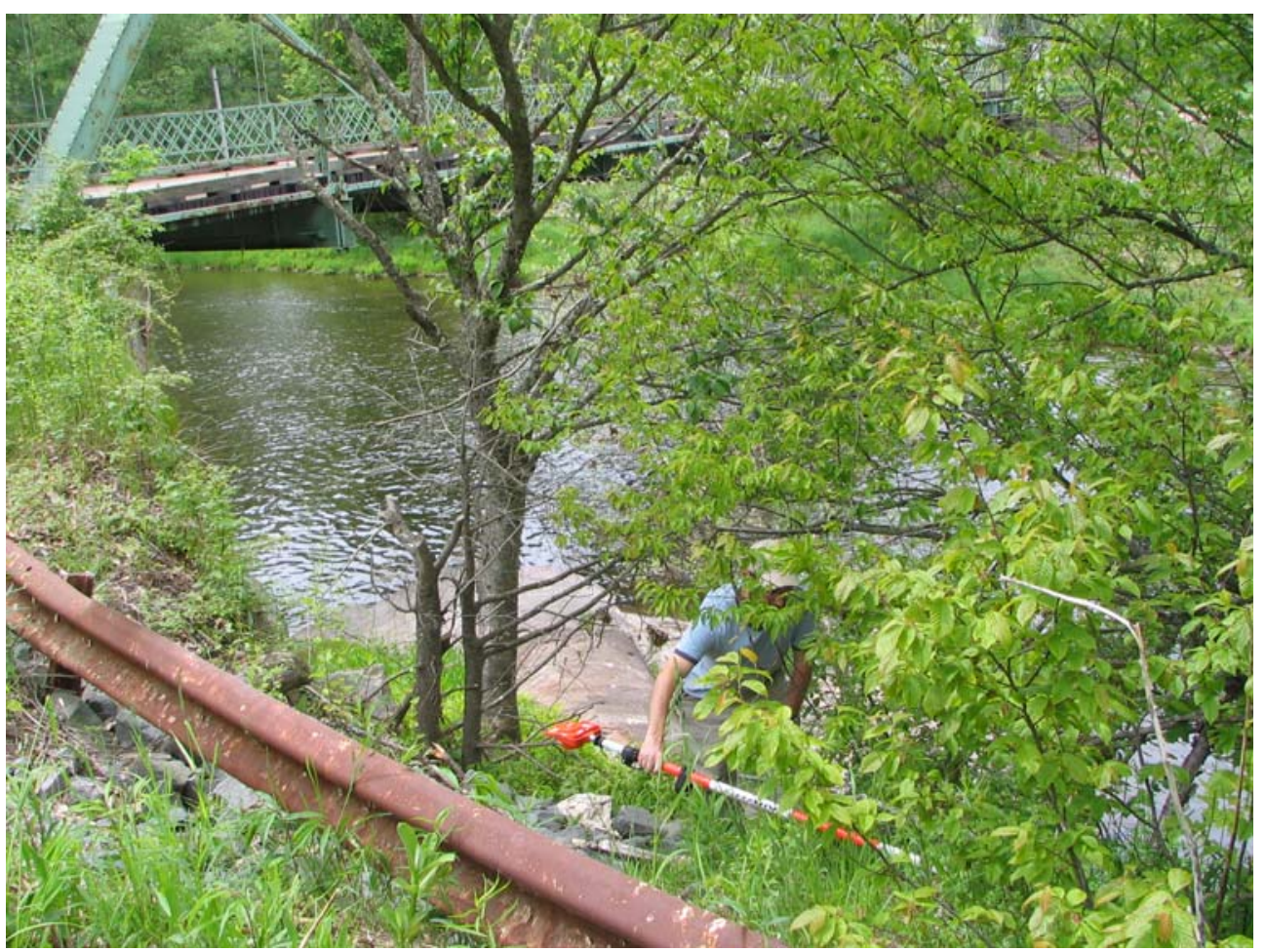

High-water mark 7.4 is a fair debris line on the ground, on the left bank, 45 feet upstream from the Ranch Hill Road bridge, at elevation 1,095.94 feet above NGVD 29 (lat $41^{\circ} 40^{\prime} 39.1^{\prime \prime}$, long $74^{\circ} 35^{\prime} 52.9^{\prime \prime}$ ).

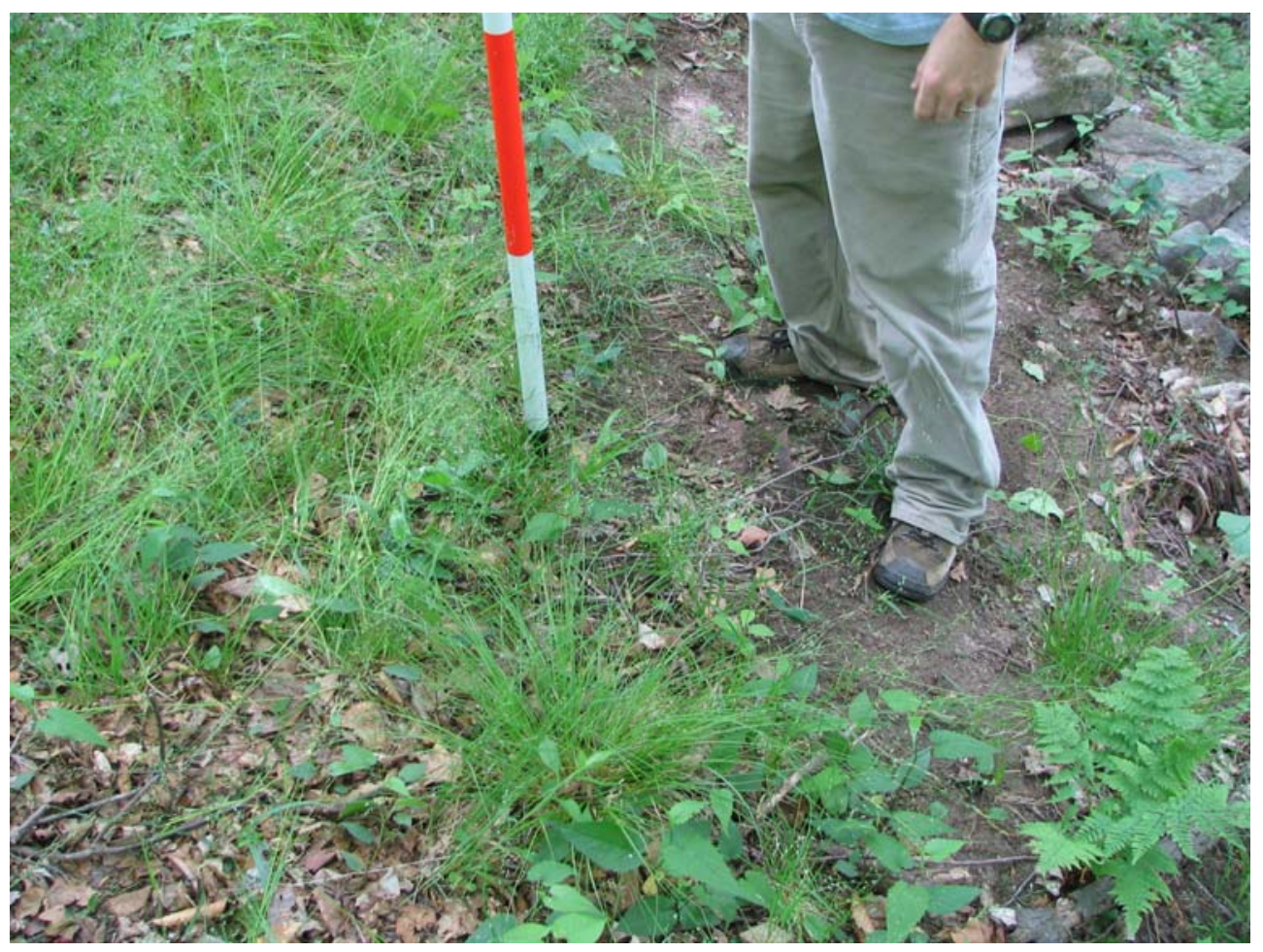

High-water mark 7.6 is a fair debris line on the ground, on the left bank, 150 feet downstream from the Ranch Hill Road bridge, at elevation 1,094.12 feet above NGVD 29 (lat $41^{\circ} 40^{\prime} 38.2^{\prime \prime}$, long $74^{\circ} 35^{\prime} 53.8^{\prime \prime}$ ). 
SITE DESCRIPTION

Site 8: Neversink River at USGS stream-gaging station 01436690 at Bridgeville, N.Y.

Site Location: USGS stream-gaging station 01436690, lat $41^{\circ} 38^{\prime} 16.7^{\prime \prime}$, long $74^{\circ} 37^{\prime} 02.2^{\prime \prime}$, NAD 83

Town of Thompson, Sullivan County, N.Y.

Woodridge USGS 7.5' Topographic Quadrangle

High-Water Marks: Three high-water marks were surveyed: two debris lines and one seed line.

Photos and GPS readings were taken at each high-water mark. Field notes are filed at the USGS office in Troy, N.Y.

Marks were surveyed and photos taken by T.P. Suro and T.F. Hoffman on June 2, 2005.

High-water-mark elevations were surveyed from a reference mark that is a chiseled square on top of foundation at corner of

State Route 17 overpass column on east side of Edwards Road and north of State Route 17. This is RM 14 in the Town of

Thompson FEMA flood-insurance study. Elevation is 1,081.44 feet above NGVD 29. To convert to NAVD 88, subtract 0.58

feet from all elevations at this site.

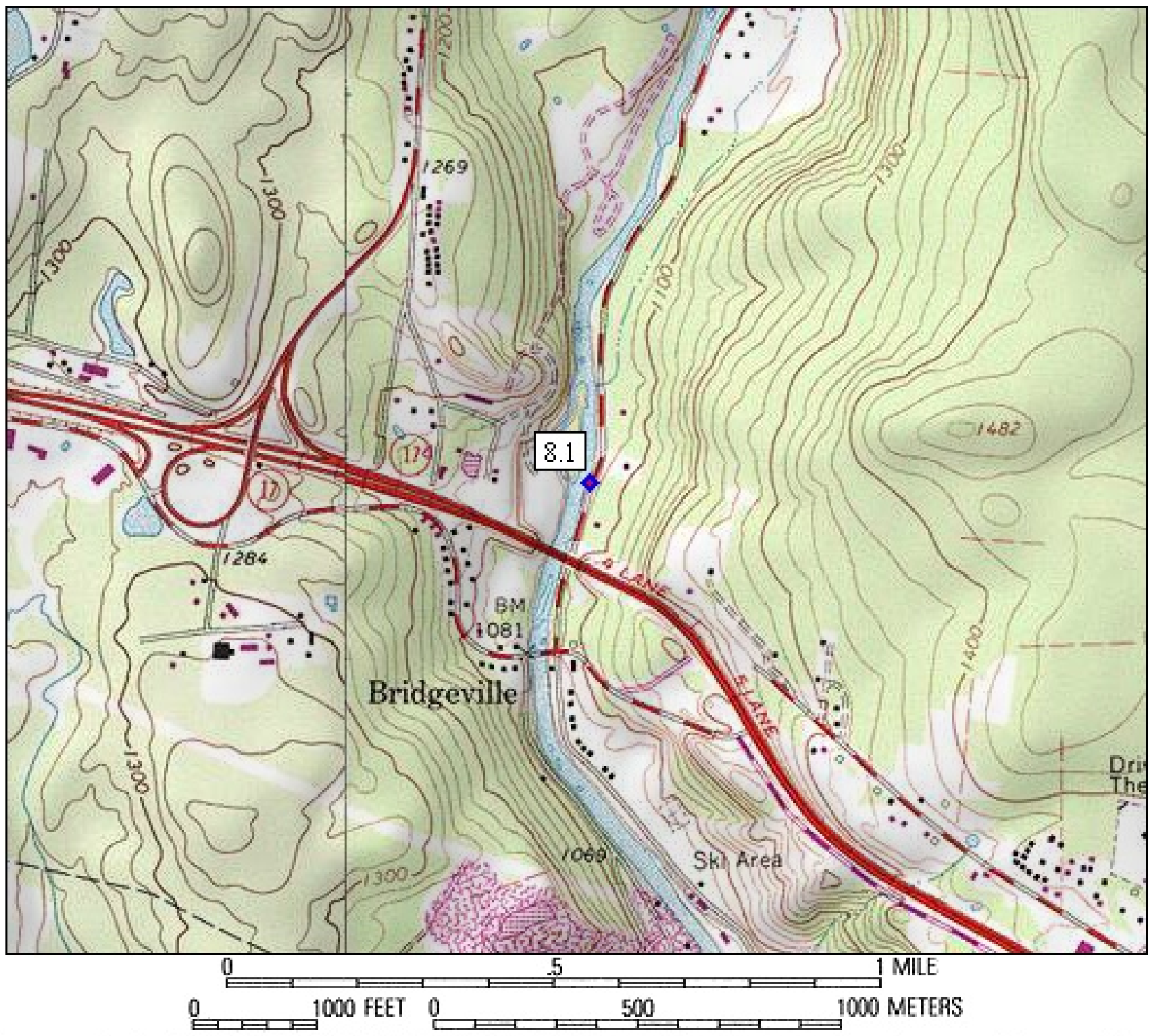

Map created with TOPO!(B) (G003 National Geographic (www.nationalgeographic.com/topo)

Woodridge quad map with location of site 8, Neversink River at USGS stream-gaging station 01436690 at Bridgeville, N.Y. 


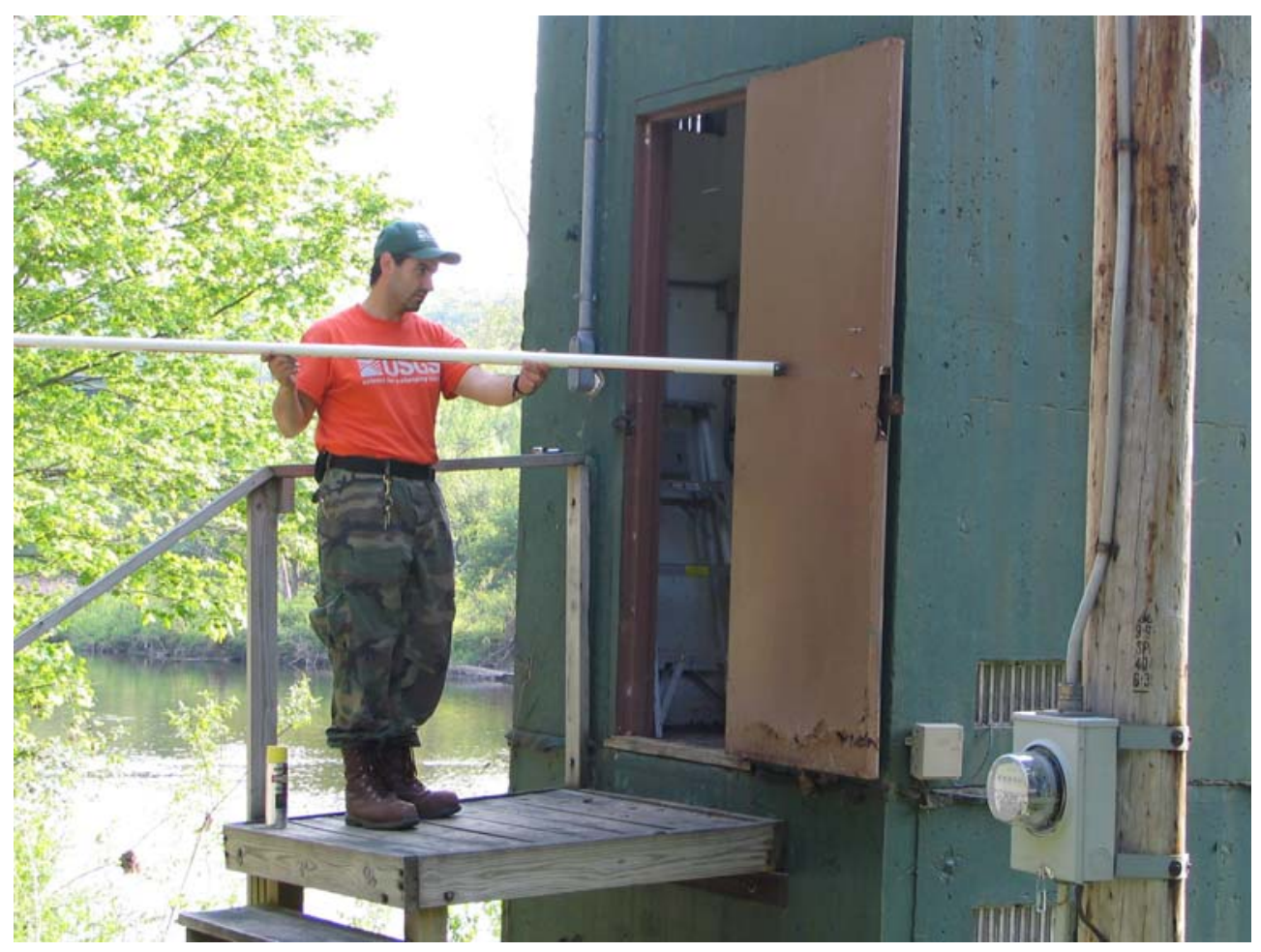

High-water mark 8.1 is an excellent seed line about 8 feet above the ground, on the landward side of the USGS stream-gaging station, on the left bank, at elevation 1,077.31 feet above NGVD 29 (lat $41^{\circ} 38^{\prime} 16.7^{\prime \prime}$, long $74^{\circ} 37^{\prime} 02.2^{\prime \prime}$ ). 


\section{SITE DESCRIPTION}

Site 9: Neversink River at State Route 17 at Bridgeville, N.Y.

Site Location: Bridge on State Route 17, lat $41^{\circ} 38^{\prime} 10.9^{\prime \prime}$, long $74^{\circ} 37^{\prime}$ 06.0”, NAD 83

Town of Thompson, Sullivan County, N.Y.

Woodridge USGS 7.5' Topographic Quadrangle

High-Water Marks: Seven high-water marks were surveyed: seven debris lines.

Photos and GPS readings were taken at each high-water mark. Field notes are filed at the USGS office in Troy, N.Y. Marks were surveyed and photos taken by T.P. Suro and T.F. Hoffman on June 2, 2005.

High-water-mark elevations were surveyed from a reference mark that is a chiseled square on top of foundation at corner of State Route 17 overpass column on east side of Edwards Road and north of State Route 17. This is RM 14 in the Town of Thompson FEMA flood-insurance study. Elevation is 1,081.44 feet above NGVD 29. To convert to NAVD 88, subtract 0.57 feet from all elevations at this site.

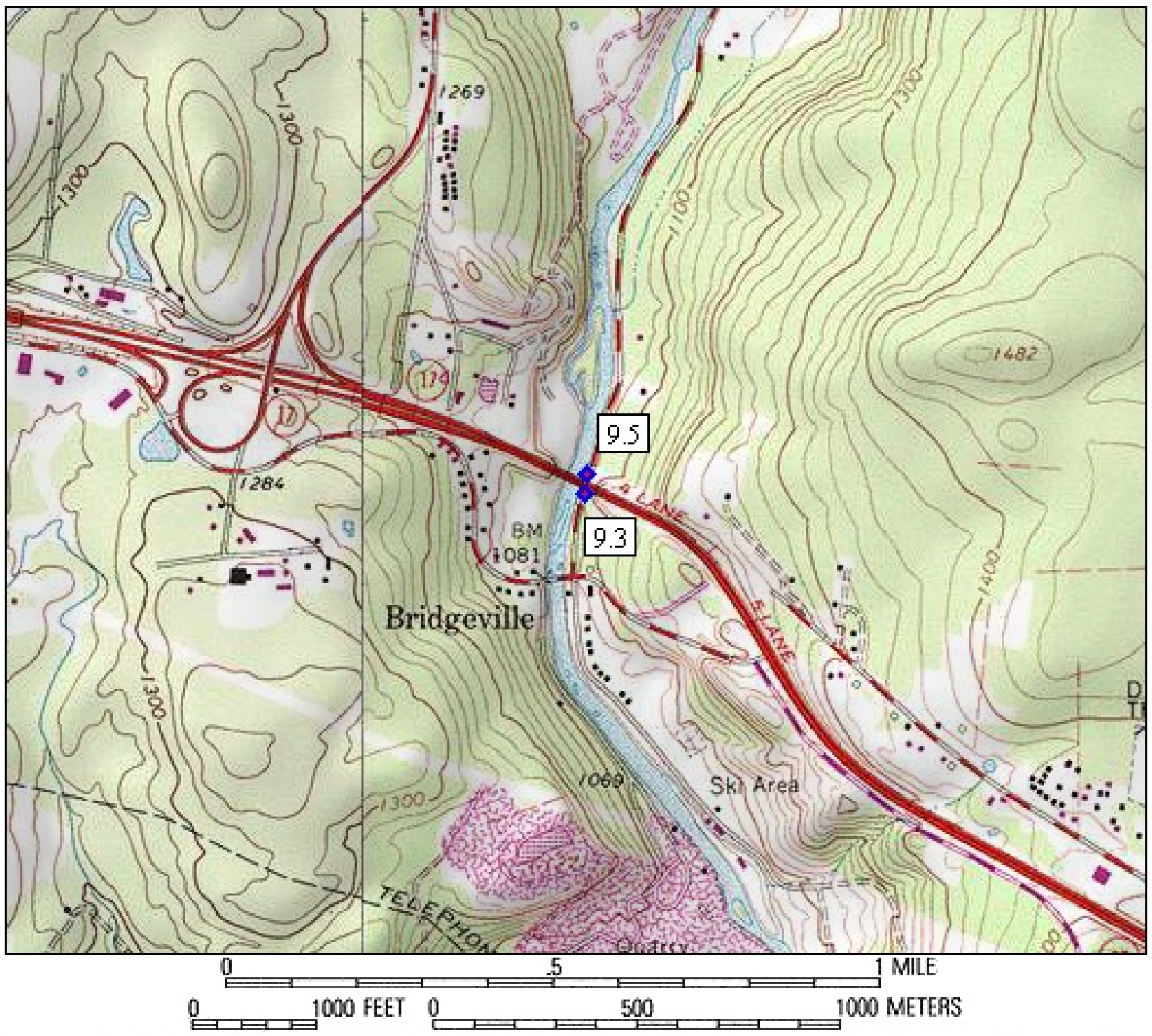

Map created with TOPO!(B) (02003 National Geographic (www.nationalgeographic. com/topo)

Woodridge quad map with location of site 9, Neversink River at State Route 17 at Bridgeville, N.Y. 


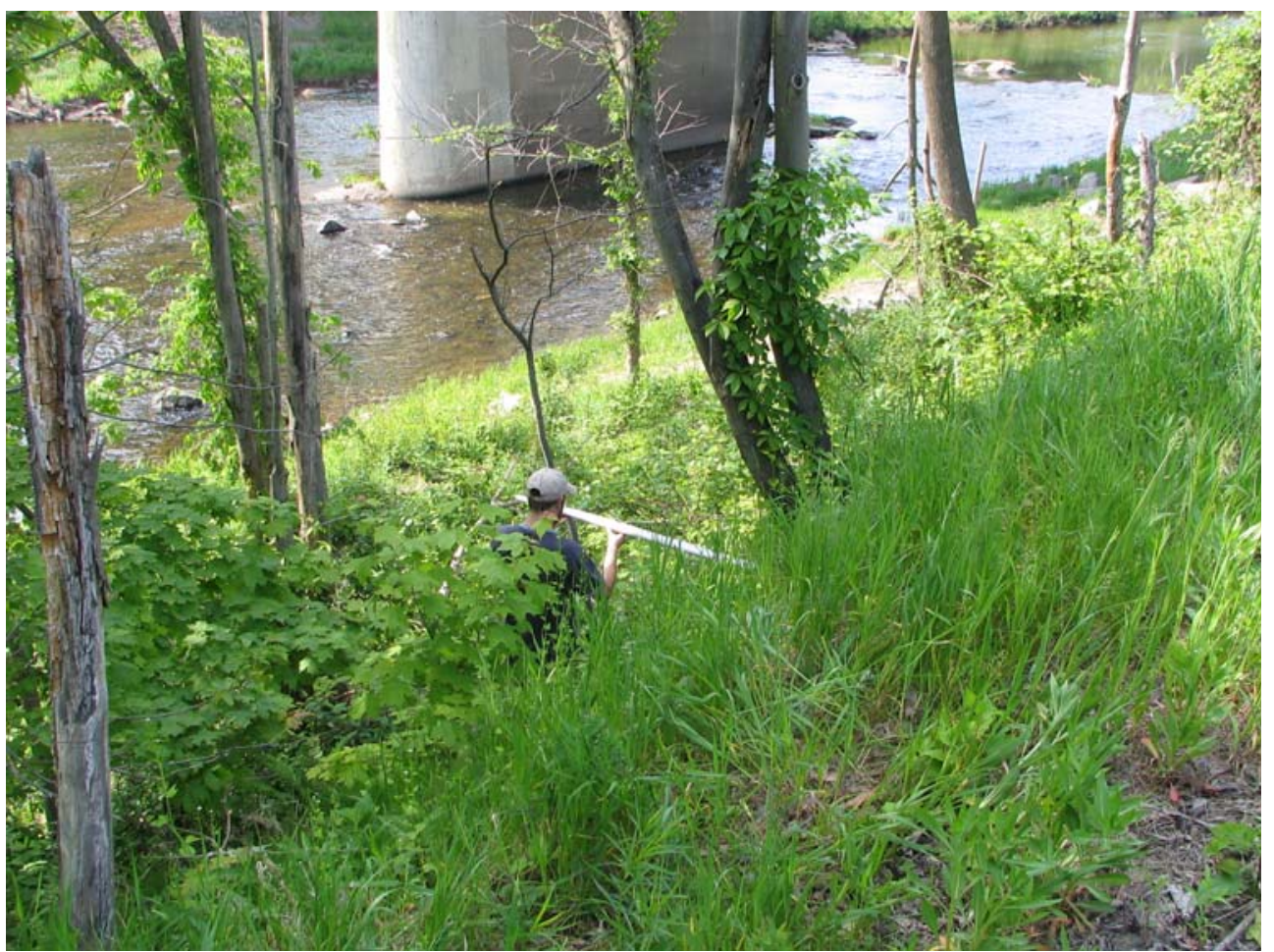

High-water mark 9.3 is a poor debris line on the ground, on the left bank, 40 feet downstream from the State Route 17 bridge, at elevation 1,075.90 feet above NGVD 29 (lat $41^{\circ} 38^{\prime} 09.8^{\prime \prime}$, long $74^{\circ} 37^{\prime} 04.7^{\prime \prime}$ ).

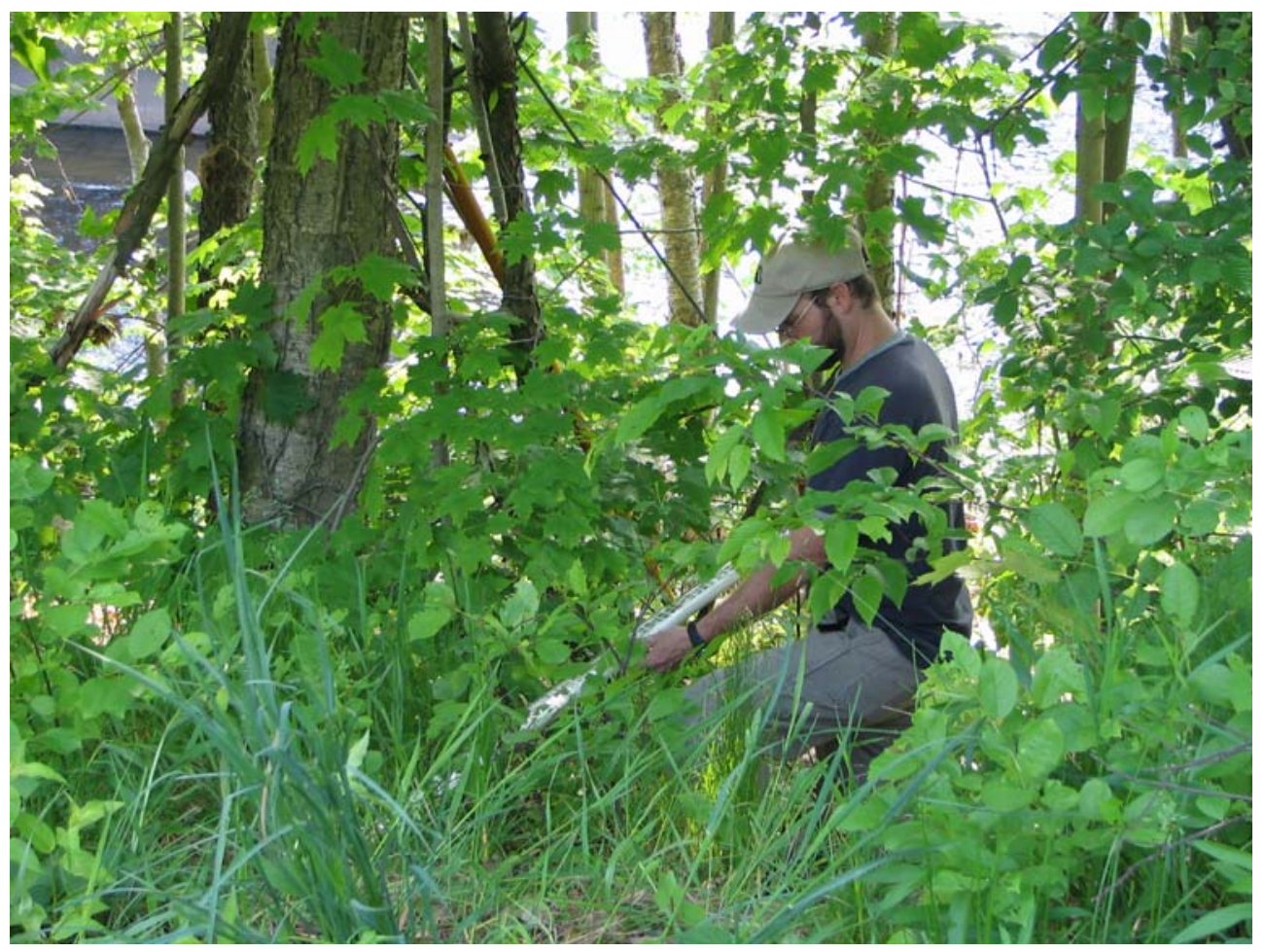

High-water mark 9.5 is a poor debris line on the ground, on the left bank, 75 feet upstream from the State Route 17 bridge, at elevation 1,076.60 feet above NGVD 29 (lat $41^{\circ} 38^{\prime} 11.5^{\prime \prime}$, long $74^{\circ} 37^{\prime} 04.5^{\prime \prime}$ ). 


\section{SITE DESCRIPTION}

Site 10: Neversink River at County Route 173 at Bridgeville, N.Y.

Site Location: Bridge on County Route 173, lat $41^{\circ} 38^{\prime}$ 03.1”, long $74^{\circ} 37^{\prime} 07.7^{\prime \prime}$, NAD 83

Town of Thompson, Sullivan County, N.Y.

Woodridge USGS 7.5' Topographic Quadrangle

High-Water Marks: Seven high-water marks were surveyed: seven debris lines.

Photos and GPS readings were taken at each high-water mark. Field notes are filed at the USGS office in Troy, N.Y. Marks were surveyed and photos taken by T.P. Suro and T.F. Hoffman on June 2, 2005.

High-water-mark elevations were surveyed from a reference mark that is a chiseled square on the northwest wingwall at angle point on north side of County Route 173 bridge. This is RM 15 in the Town of Thompson FEMA flood-insurance study. Elevation is $1,080.76$ feet above NGVD 29. To convert to NAVD 88, subtract 0.57 feet from all elevations at this site.

Thalweg Elevation: 1,055.5 feet above NGVD 29.

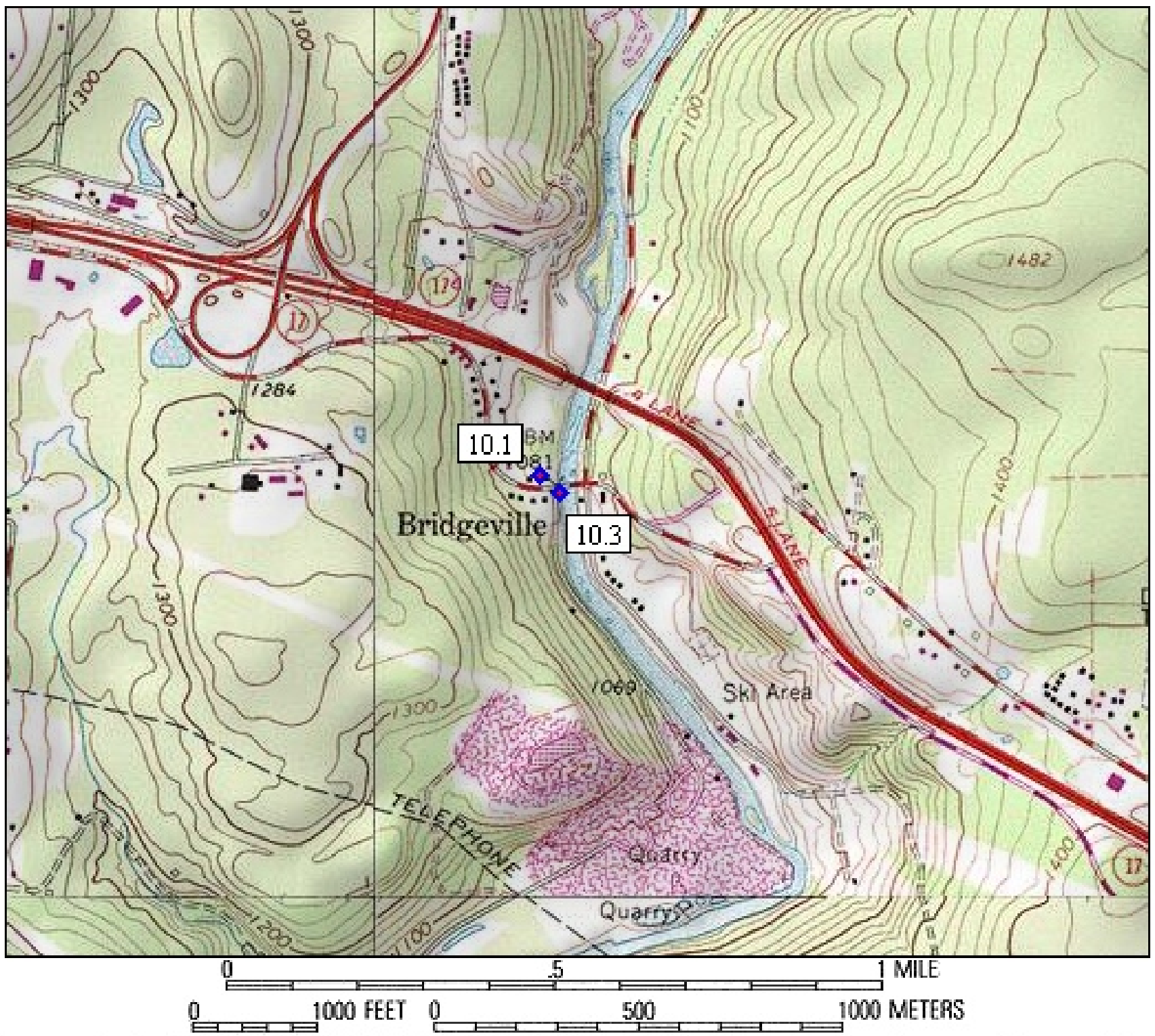

Map created with TOPO! ( 82003 National Geographic (www.nationalgeographic.com/topo)

Woodridge quad map with location of site 10, Neversink River at County Route 173 at Bridgeville, N.Y. 


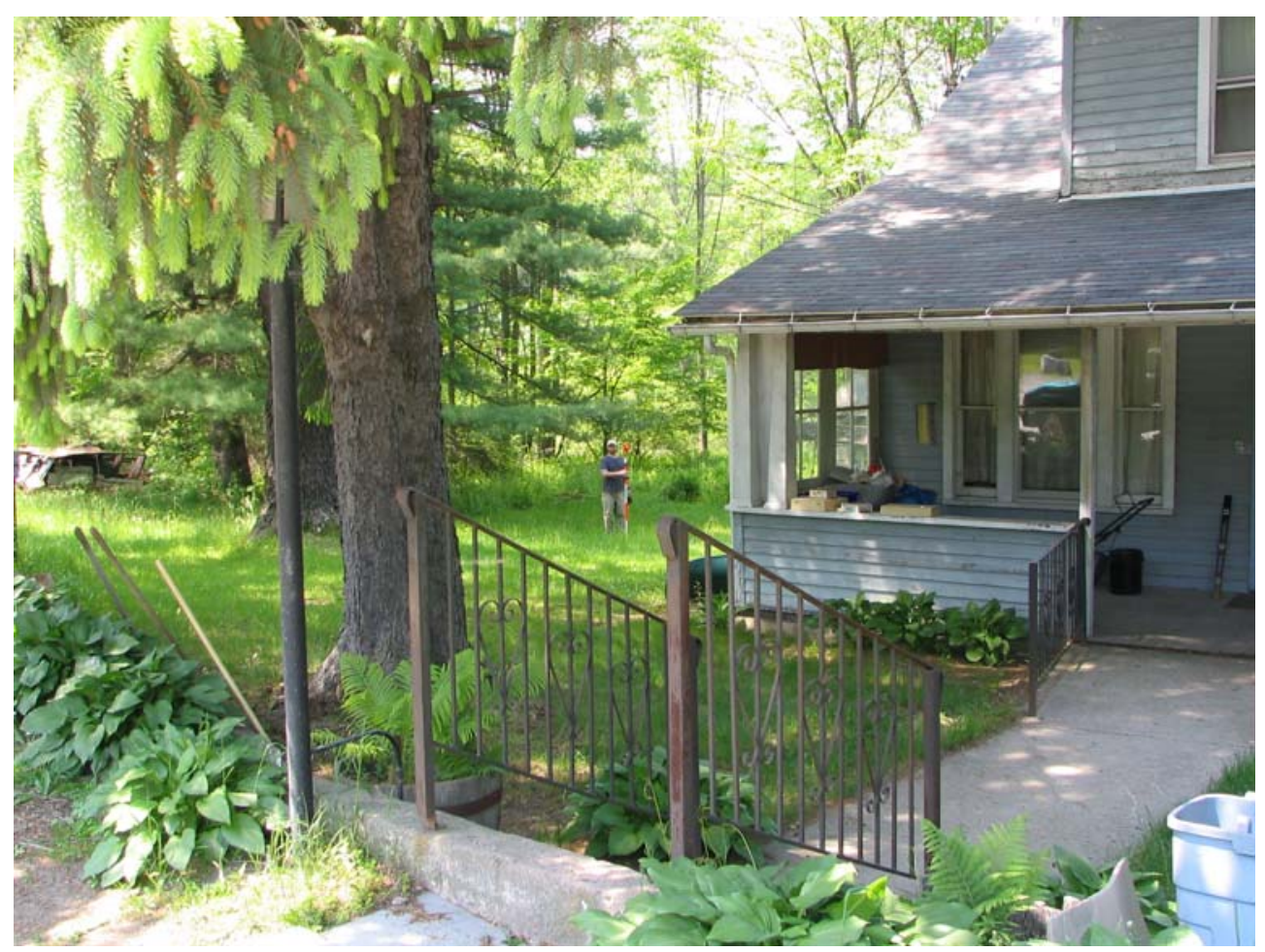

High-water mark 10.1 is a fair debris line on the ground, in the side yard of house 447 on County Route 173, on the right bank, 65 feet upstream from the County Route 173 bridge, at elevation 1,075.60 feet above NGVD 29 (lat $41^{\circ} 38^{\prime} 03.8^{\prime \prime}$, long $74^{\circ} 37^{\prime}$ $10.9 ")$.

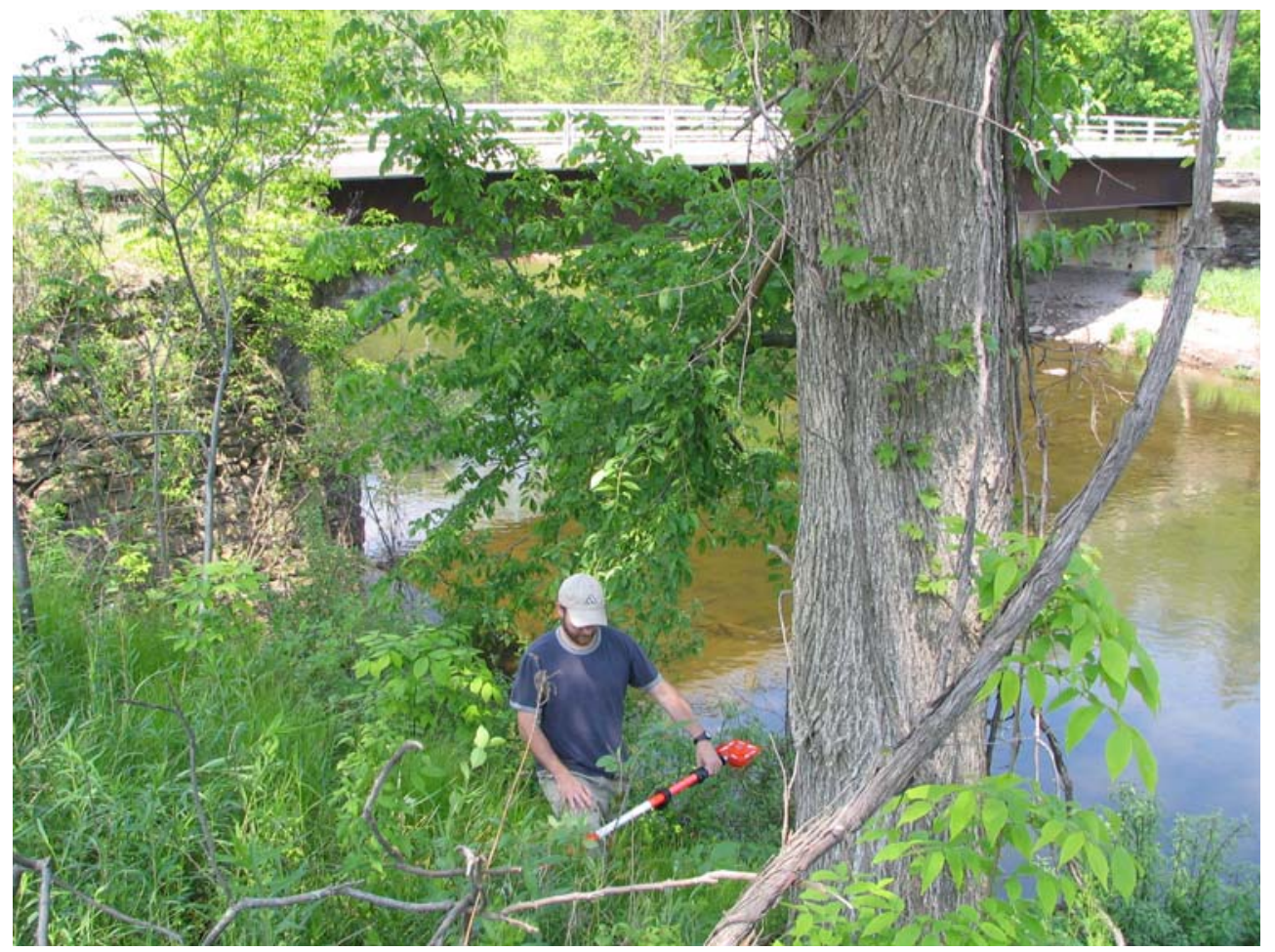

High-water mark 10.3 is a poor debris line on the ground, on the right bank, 66 feet downstream from the County Route 173 bridge, at elevation 1,074.83 feet above NGVD 29 (lat $41^{\circ} 38^{\prime} 02.3^{\prime \prime}$, long $74^{\circ} 37^{\prime} 08.8^{\prime \prime}$ ). 
SITE DESCRIPTION

Site 11: Neversink River at County Route 49 at Oakland Valley, N.Y.

Site Location: Bridge on County Route 49, lat $41^{\circ} 30^{\prime} 16.5^{\prime \prime}$, long $74^{\circ} 38^{\prime} 51.8^{\prime \prime}$, NAD 83

Town of Forestburg, Sullivan County, N.Y.

Hartwood USGS 7.5' Topographic Quadrangle

High-Water Marks: Five high-water marks were surveyed: five debris lines.

Photos and GPS readings were taken at each high-water mark. Field notes are filed at the USGS office in Troy, N.Y.

Marks were surveyed and photos taken by T.P. Suro and T.F. Hoffman on June 2, 2005.

High-water-mark elevations were surveyed from a benchmark that is a USGS standard disk stamped 686 ALBANY ADJ 1903

set in ledge rock cliff 34 feet southeast of the centerline of the south abutment of the old bridge over the Neversink River (old

bridge deck has been removed). Elevation is 685.37 feet above NGVD 29. To convert to NAVD 88, subtract 0.56 feet from all elevations at this site.

Thalweg Elevation: 660.2 feet above NGVD 29.

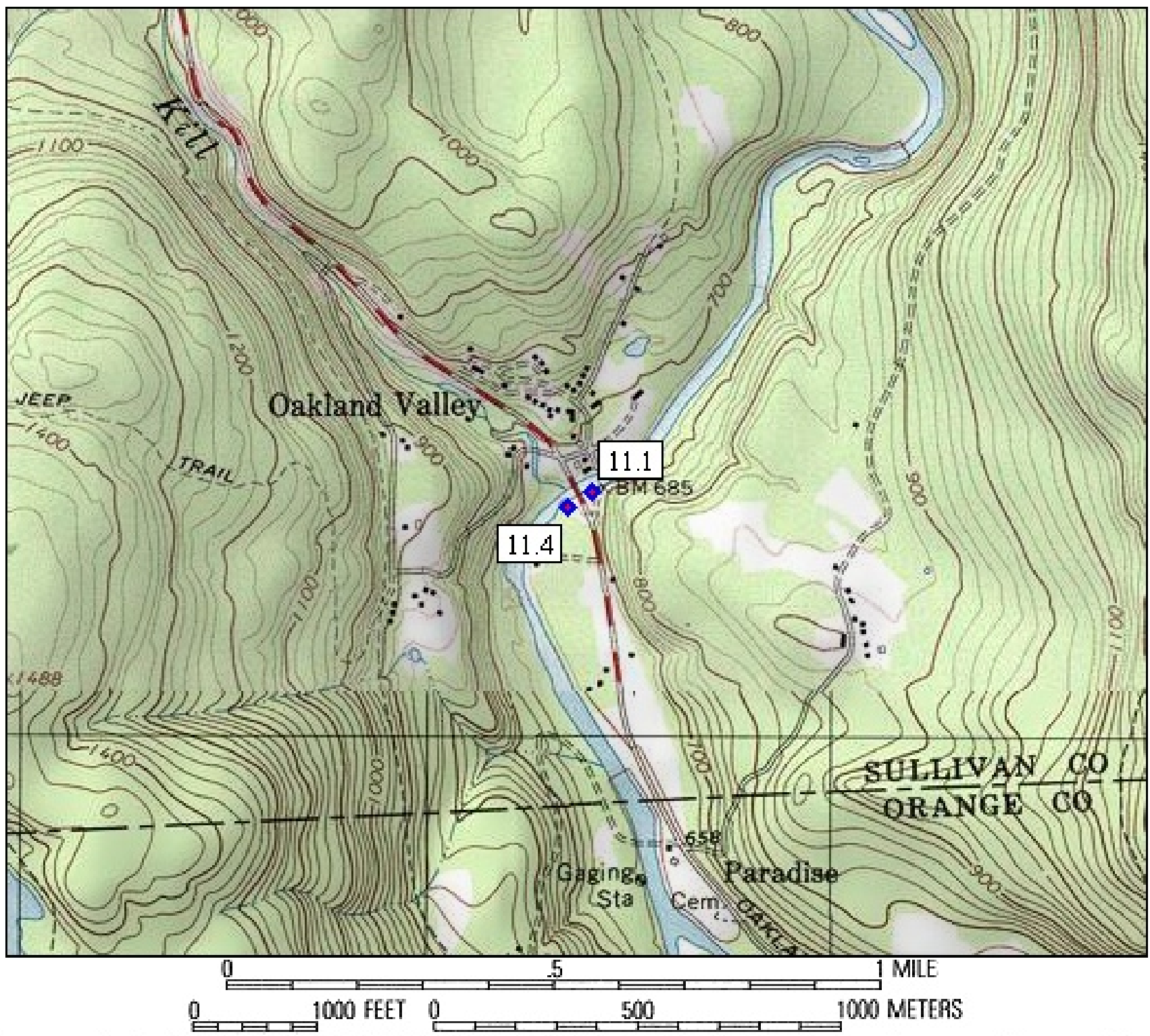

Map created with TOPO! (62003 National Geographic (www nationalgeographic.com/topo)

Hartwood quad map with location of site 11, Neversink River at County Route 49 at Oakland Valley, N.Y. 


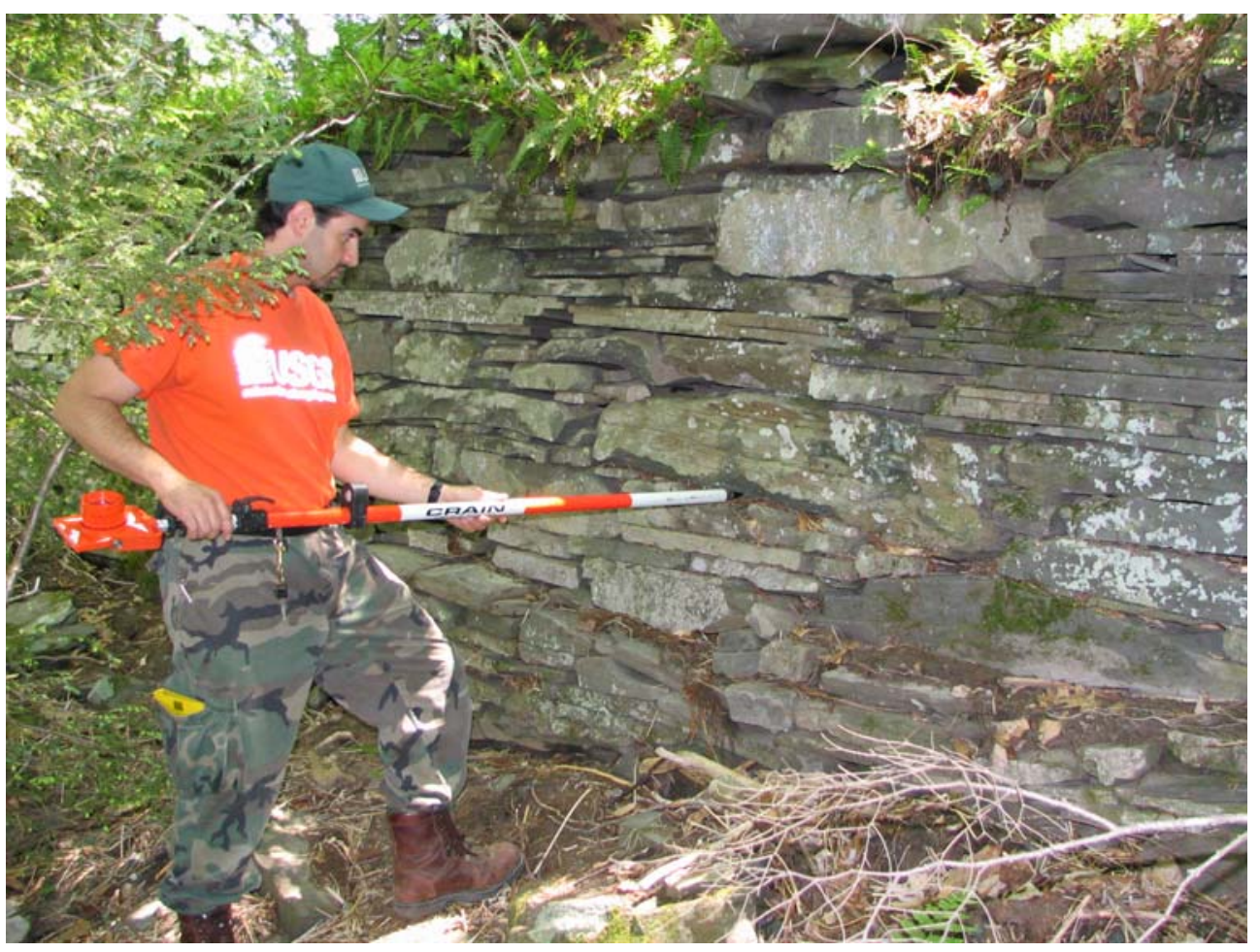

High-water mark 11.1 is a good debris line 2.6 feet above the ground, on the streamward side of a stone wall, on the left bank, 175 feet upstream from the County Route 49 bridge, at elevation 675.63 feet above NGVD 29 (lat $41^{\circ} 30^{\prime} 16.3^{\prime \prime}$, long $74^{\circ} 38^{\prime}$ $50.0 ")$.

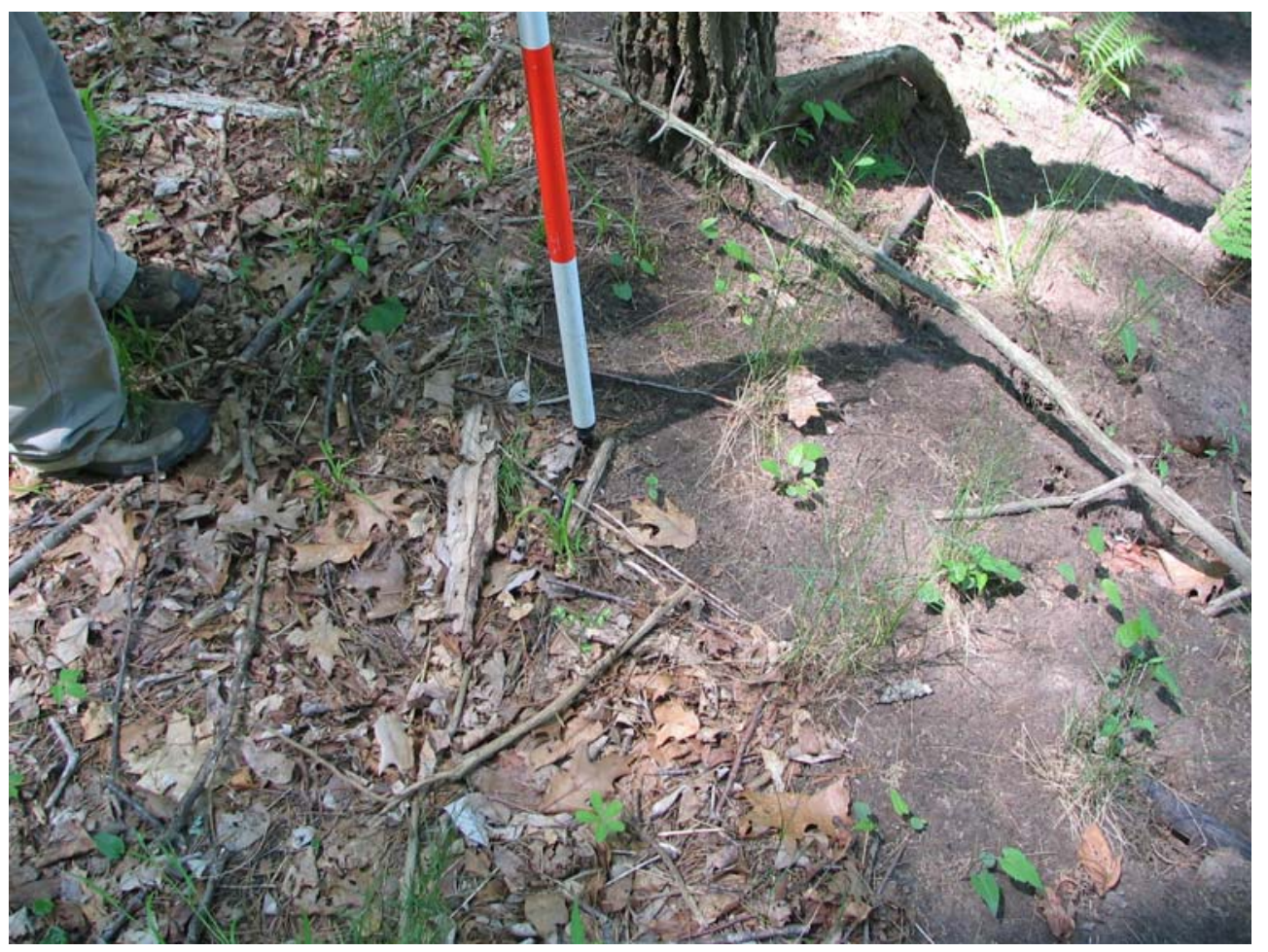

High-water mark 11.4 is a poor debris line on the ground, on the left bank, 100 feet downstream from the County Route 49 bridge, at elevation 674.29 feet above NGVD 29 (lat $41^{\circ} 30^{\prime} 15.1^{\prime \prime}$, long $74^{\circ} 38^{\prime} 52.5^{\prime \prime}$ ). 
SITE DESCRIPTION

Site 12: Neversink River at Paradise Road at Oakland Valley, N.Y.

Site Location: Bridge on Paradise Road, lat $41^{\circ} 29^{\prime} 48.2^{\prime \prime}$, long $74^{\circ} 38^{\prime} 44.3^{\prime \prime}$, NAD 83

Town of Deerpark, Orange County, N.Y.

Port Jervis North USGS 7.5' Topographic Quadrangle

High-Water Marks: Thirteen high-water marks were surveyed: 13 debris lines.

Photos and GPS readings were taken at each high-water mark. Field notes are filed at the USGS office in Troy, N.Y.

Marks were surveyed and photos taken by T.P. Suro and K.D. Reisig on June 9, 2005, and T.P. Suro and A.M. Gearwar on November 15, 2005.

High-water-mark elevations were surveyed from a reference mark that is the USGS stream-gaging station 01437000

(discontinued) reference mark RM 1. Elevation is 641.84 feet above NGVD 29. To convert to NAVD 88, subtract 0.57 feet from all elevations at this site.

Thalweg Elevation: 624.8 feet above NGVD 29.

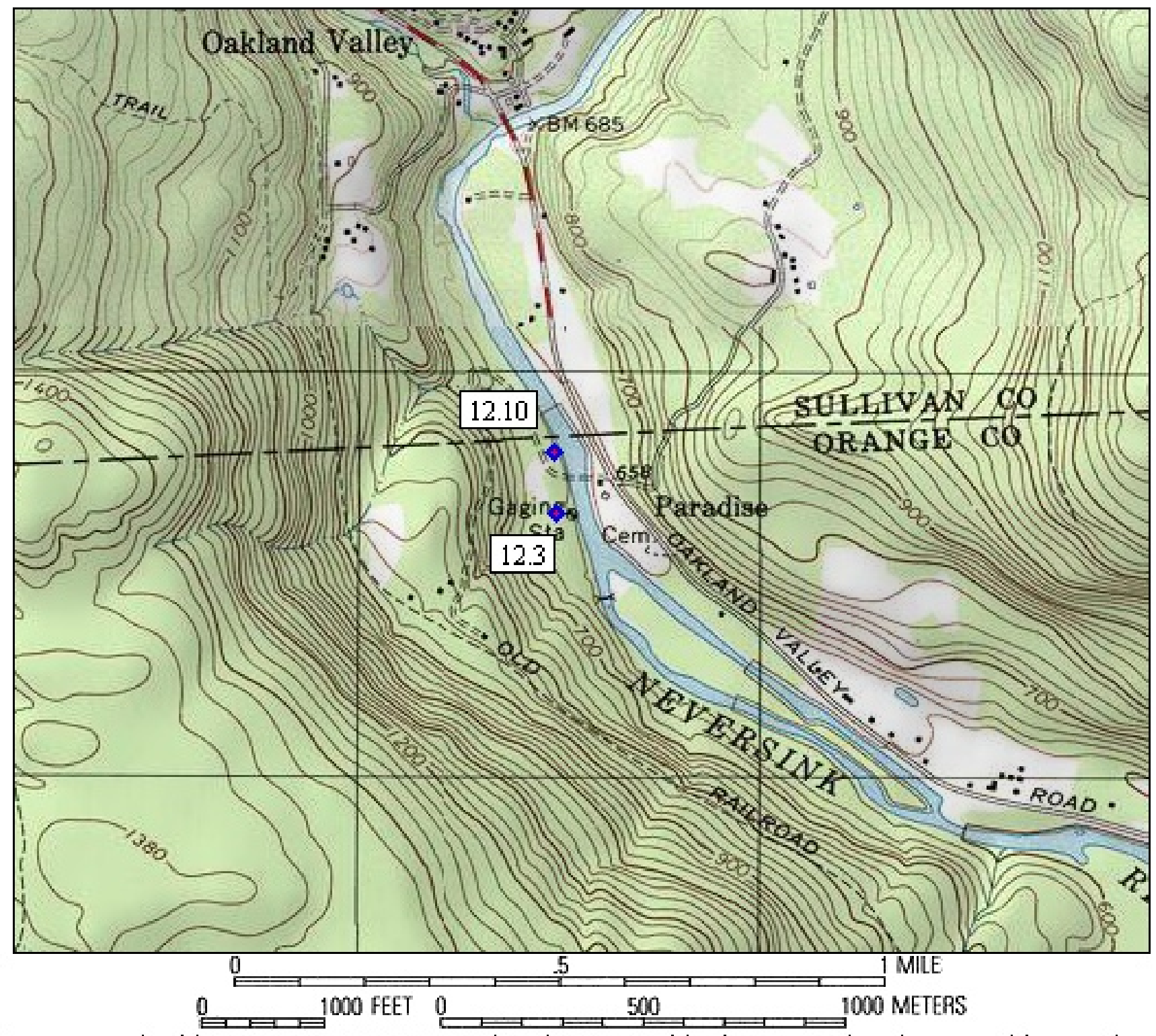

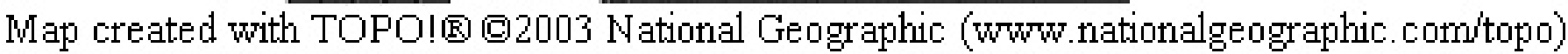

Port Jervis North quad map with location of site 12, Neversink River at Paradise Road at Oakland Valley, N.Y. 


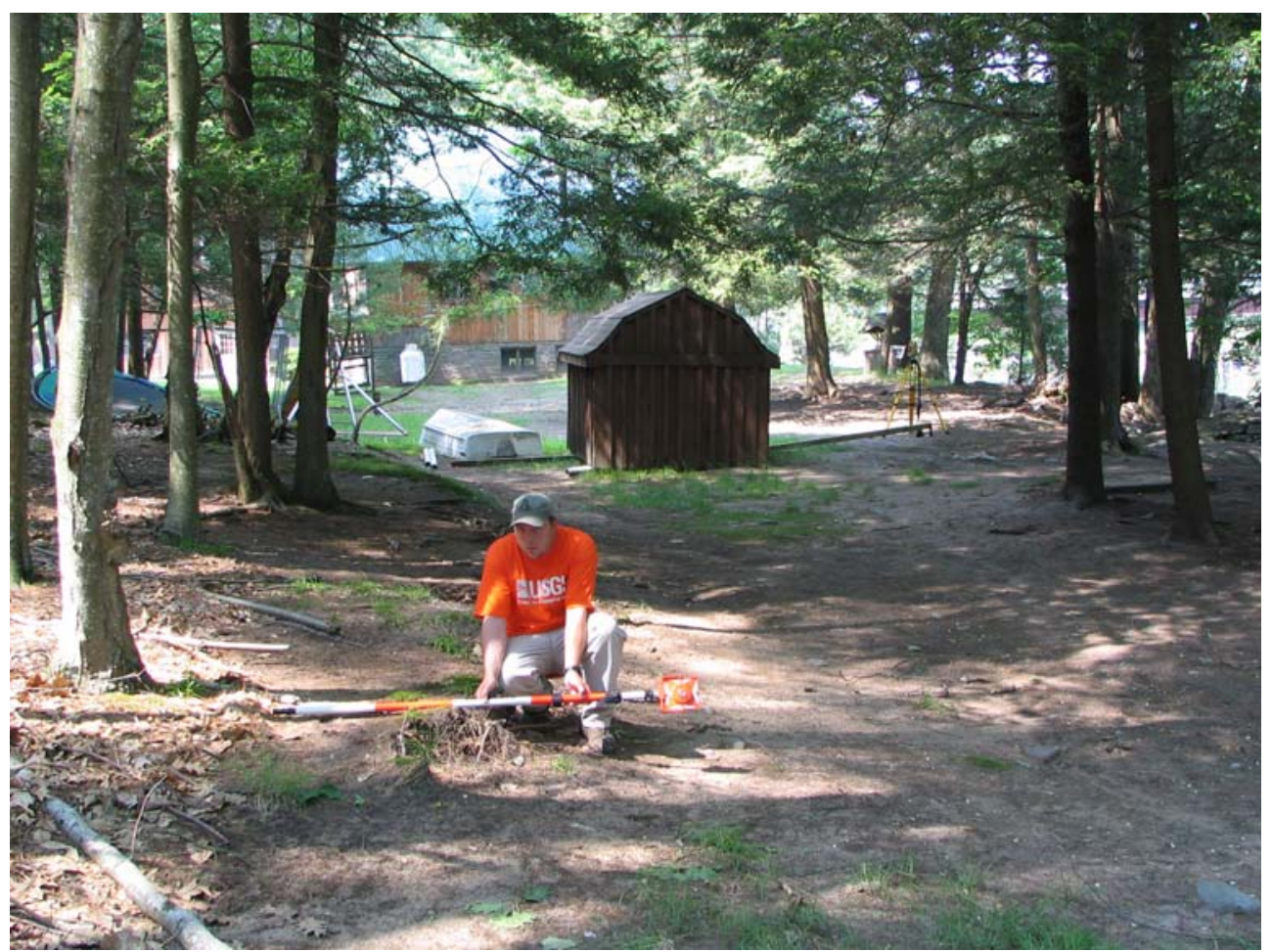

High-water mark 12.3 is a fair debris line on the ground, on the right bank, 275 feet downstream from the Paradise Road bridge, at elevation 645.50 feet above NGVD 29 (lat $41^{\circ} 29^{\prime} 45.4^{\prime \prime}$, long $74^{\circ} 38^{\prime} 46.5^{\prime \prime}$ ).

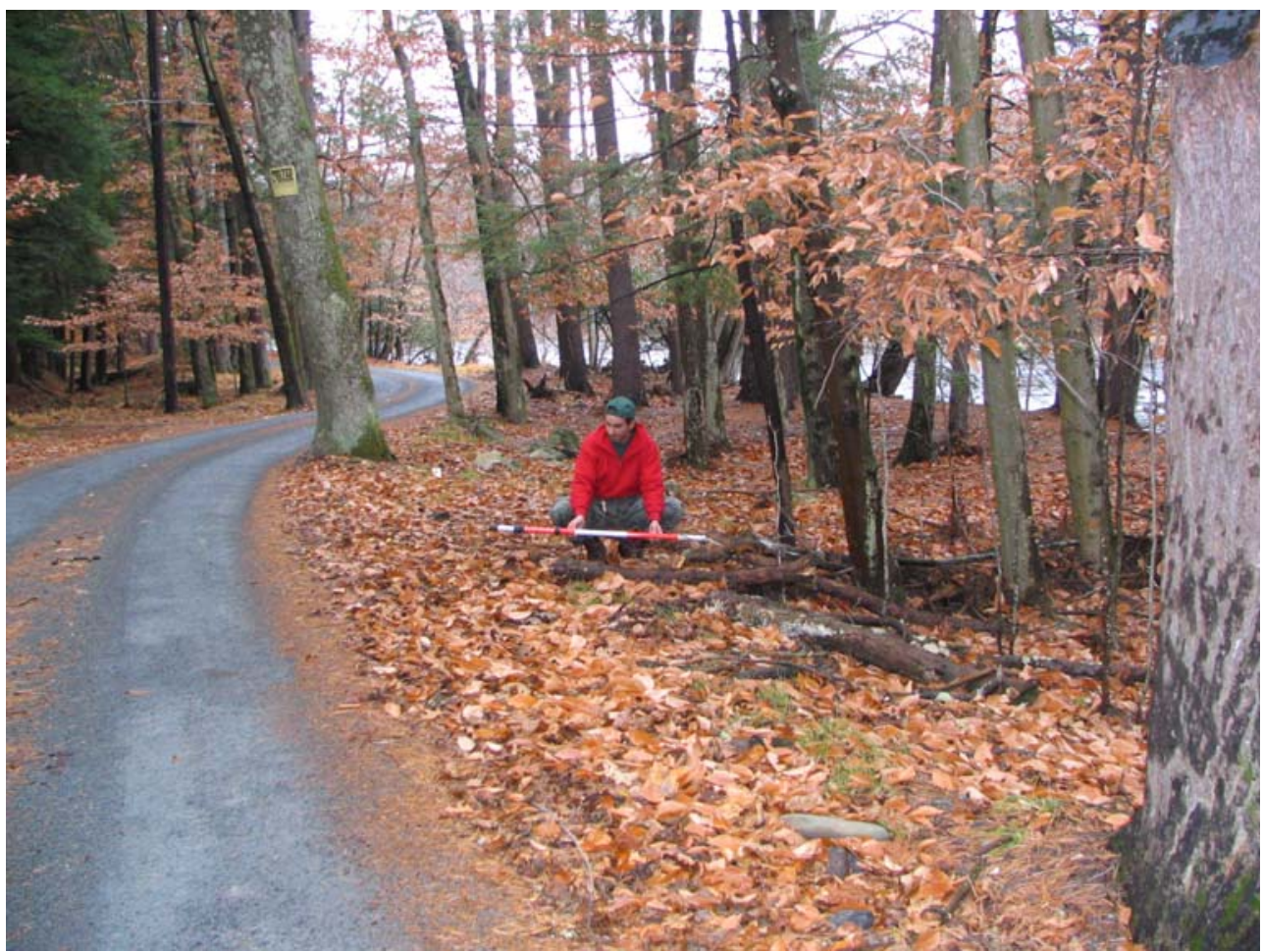

High-water mark 12.10 is a poor debris line on the ground, on the right bank, 210 feet upstream from the Paradise Road bridge, at elevation 647.00 feet above NGVD 29 (lat $41^{\circ} 29^{\prime} 50.2^{\prime \prime}$, long $\left.74^{\circ} 38^{\prime} 46.7^{\prime \prime}\right)$. 
SITE DESCRIPTION

Site 13: Neversink River at U.S. Route 209 at Cuddebackville, N.Y.

Site Location: Bridge on U.S. Route 209, lat $41^{\circ} 27^{\prime} 20.4^{\prime \prime}$, long $74^{\circ} 36^{\prime} 01.2^{\prime \prime}$, NAD 83

Town of Deerpark, Orange County, N.Y.

Otisville USGS 7.5' Topographic Quadrangle

High-Water Marks: Nine high-water marks were surveyed: six seed lines and three debris lines.

Photos and GPS readings were taken at each high-water mark. Field notes are filed at the USGS office in Troy, N.Y.

Marks were surveyed and photos taken by G.D. Firda, R. Lumia, and B.J. Zatorsky on April 12, 2005, and G.D. Firda and

A.M. Gearwar on June 9, 2005.

High-water-mark elevations were surveyed from a benchmark that is an NGS standard disk stamped H 4151978 set in top of the southwest end of abutment of the southwest end of the U.S. Route 209 bridge, NGS PID LY2072. This is RM 15 in the Town of Deerpark FEMA flood-insurance study. Elevation is 508.91 feet above NGVD 29. To convert to NAVD 88, subtract 0.62 feet from all elevations at this site.

Thalweg Elevation: 487.3 feet above NGVD 29.

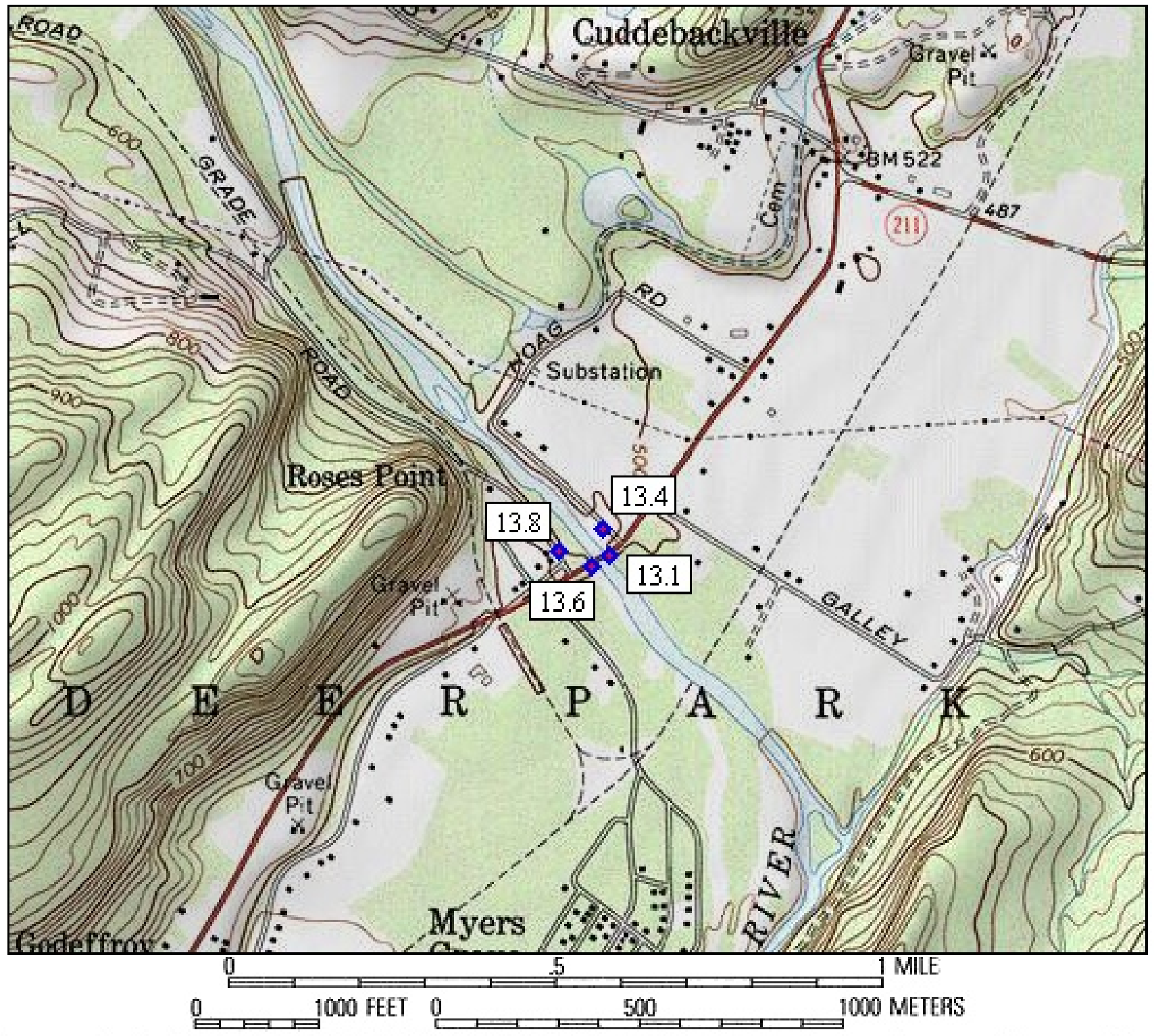

Map created with TOPO!(B) (02003 National Geographic (www.nationalgeographic.com/topo)

Otisville quad map with location of site 13, Neversink River at U.S. Route 209 at Cuddebackville, N.Y. 


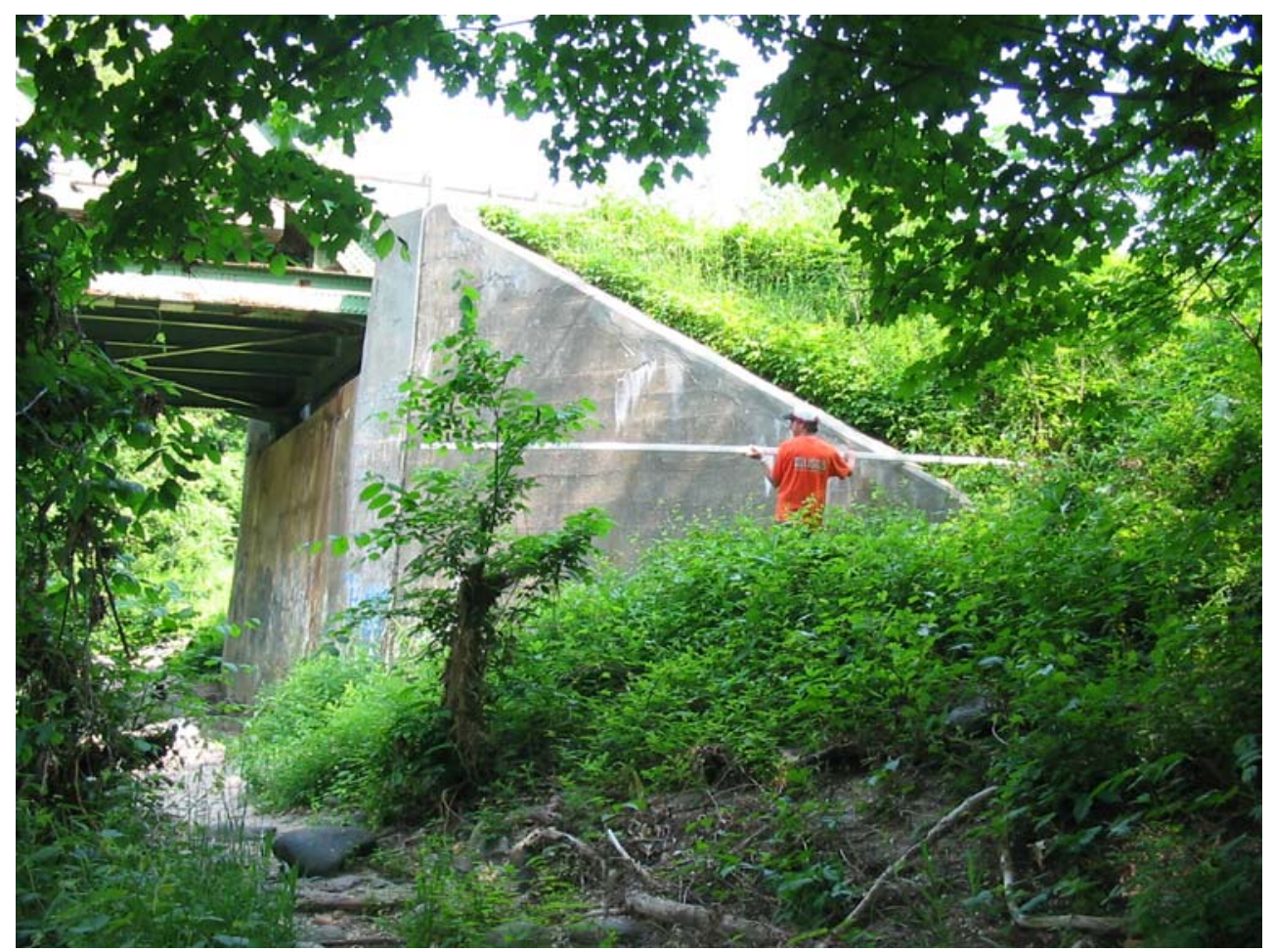

High-water mark 13.1 is an excellent seed line on the ground, on the left bank, 20 feet downstream from the U.S. Route 209 bridge, at elevation 498.44 feet above NGVD 29 (lat $41^{\circ} 27^{\prime} 20.9^{\prime \prime}$, long $\left.74^{\circ} 35^{\prime} 59.9^{\prime \prime}\right)$.

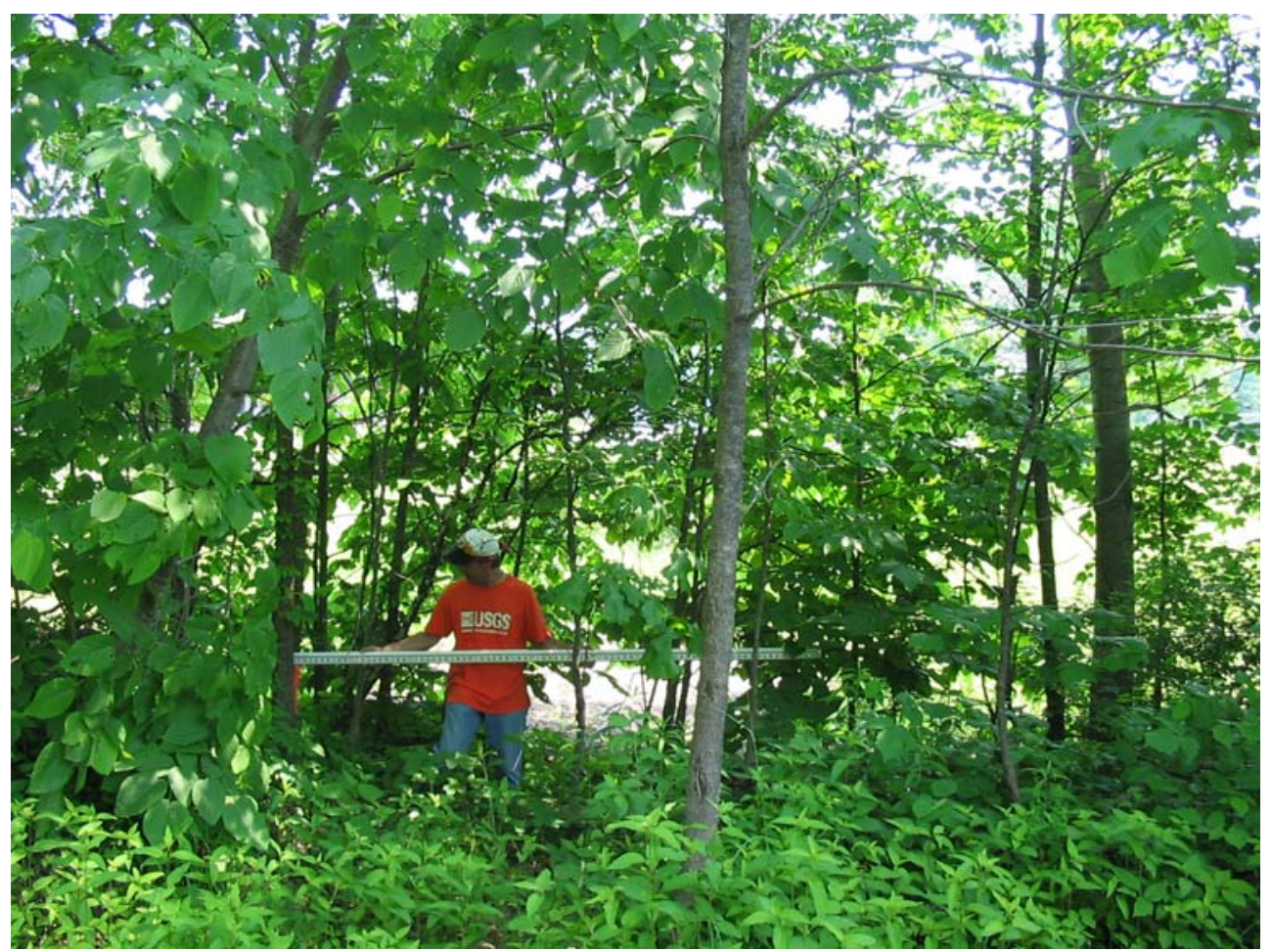

High-water mark 13.4 is an excellent seed line about 3 feet above the ground, on a tree on the left bank, 125 feet upstream from the U.S. Route 209 bridge, at elevation 499.64 feet above NGVD 29 (lat $41^{\circ} 27^{\prime} 23.0^{\prime \prime}$, long $74^{\circ} 36^{\prime} 00.7^{\prime \prime}$ ). 


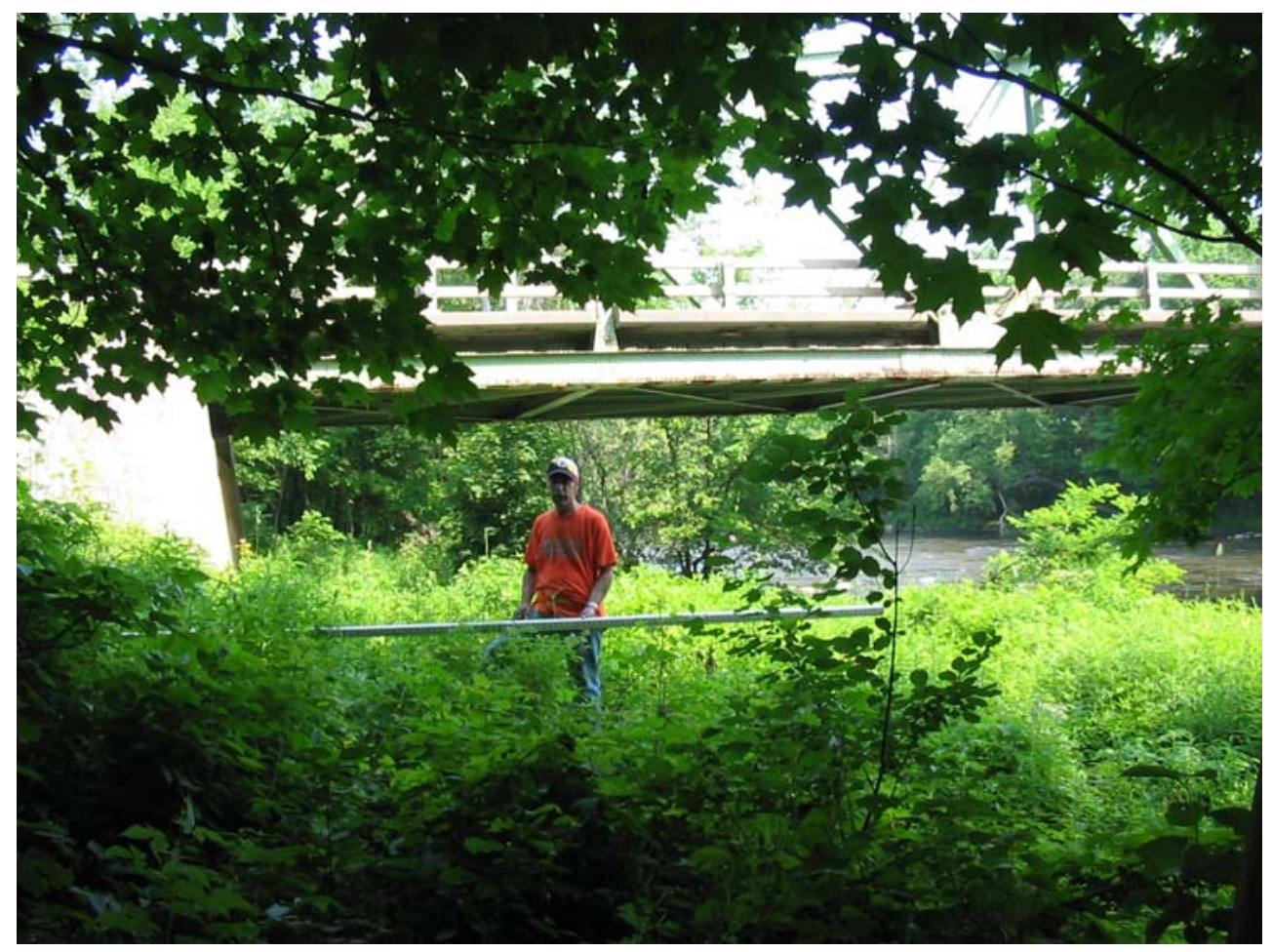

High-water mark 13.6 is a good debris line on the ground, on the right bank, 50 feet downstream from the U.S. Route 209 bridge, at elevation 497.93 feet above NGVD 29 (lat $41^{\circ} 27^{\prime} 20.0^{\prime \prime}$, long $74^{\circ} 36^{\prime} 01.9^{\prime \prime}$ ).

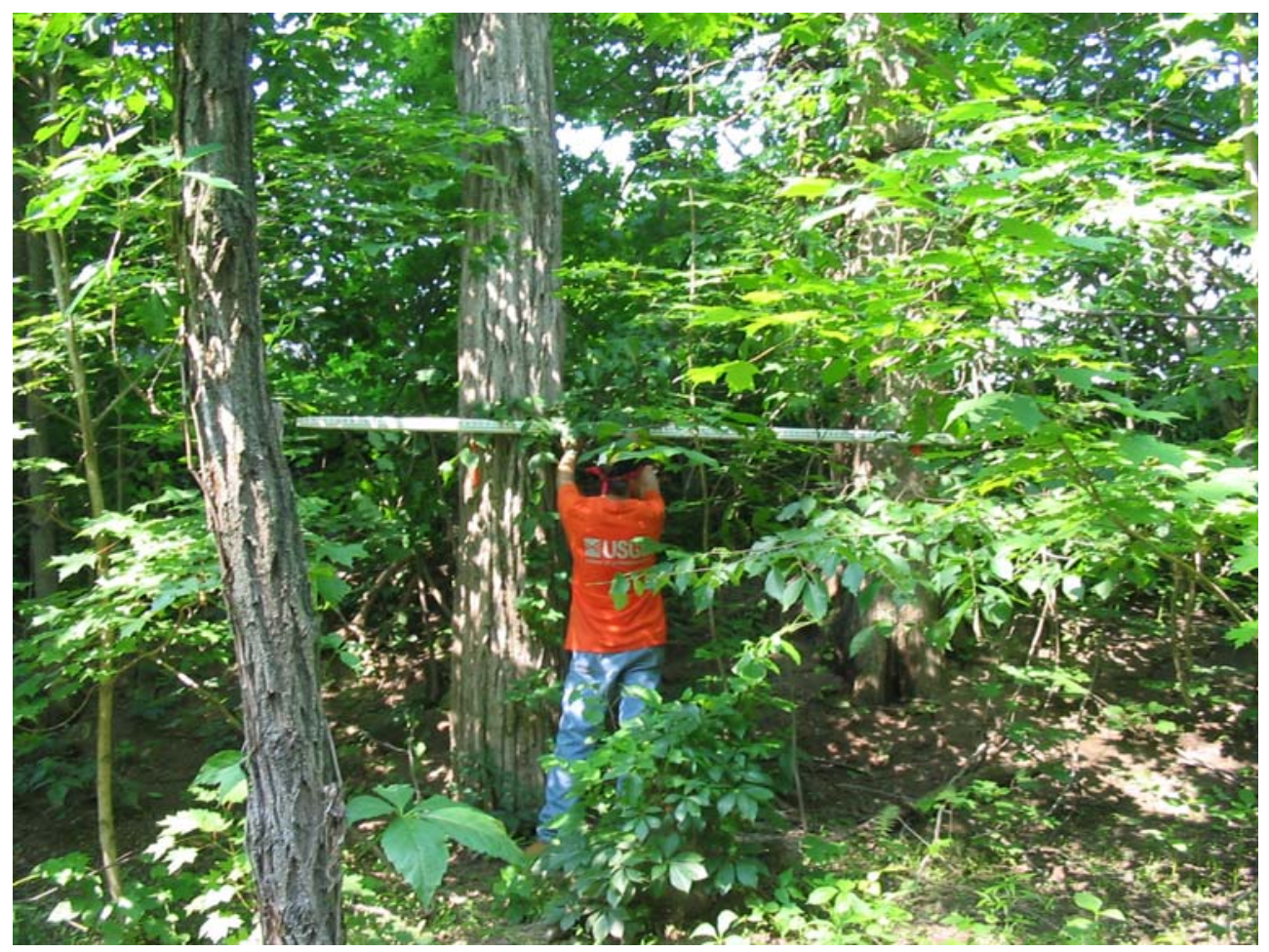

High-water mark 13.8 is an excellent seed line about 5 feet above the ground, on a tree on the right bank, 165 feet upstream from the U.S. Route 209 bridge, at elevation 499.78 feet above NGVD 29 (lat $41^{\circ} 27^{\prime} 21.2^{\prime \prime}$, long $74^{\circ} 36^{\prime} 05.3^{\prime \prime}$ ). 


\section{Page left intentionally blank}




\begin{tabular}{|l|}
\hline \multicolumn{1}{|c|}{ SITE DESCRIPTION } \\
\hline Site 14: Neversink River at Avenue E and Grove Street at Myers Grove, N.Y. \\
\hline Site Location: Avenue E and Grove Street, lat $41^{\circ} 26^{\prime} 44.1^{\prime}$, long $74^{\circ} 35^{\prime}$ 53.6”, NAD 83 \\
\hline Town of Deerpark, Orange County, N.Y. \\
\hline Otisville USGS 7.5' Topographic Quadrangle \\
\hline High-Water Marks: Three high-water marks were surveyed: two mud lines and one seed line. \\
\hline Photos and GPS readings were taken at each high-water mark. Field notes are filed at the USGS office in Troy, N.Y. \\
\hline Marks were surveyed and photos taken by G.D. Firda and A.M. Gearwar on June 9, 2005. \\
\hline $\begin{array}{l}\text { High-water-mark elevations were surveyed from a reference mark that is the USGS stream-gaging station } 01437500 \text { reference } \\
\text { mark RM 10. Elevation is 474.72 feet above NGVD 29. To convert to NAVD 88, subtract } 0.62 \text { feet from all elevations at this } \\
\text { site. }\end{array}$ \\
\hline
\end{tabular}

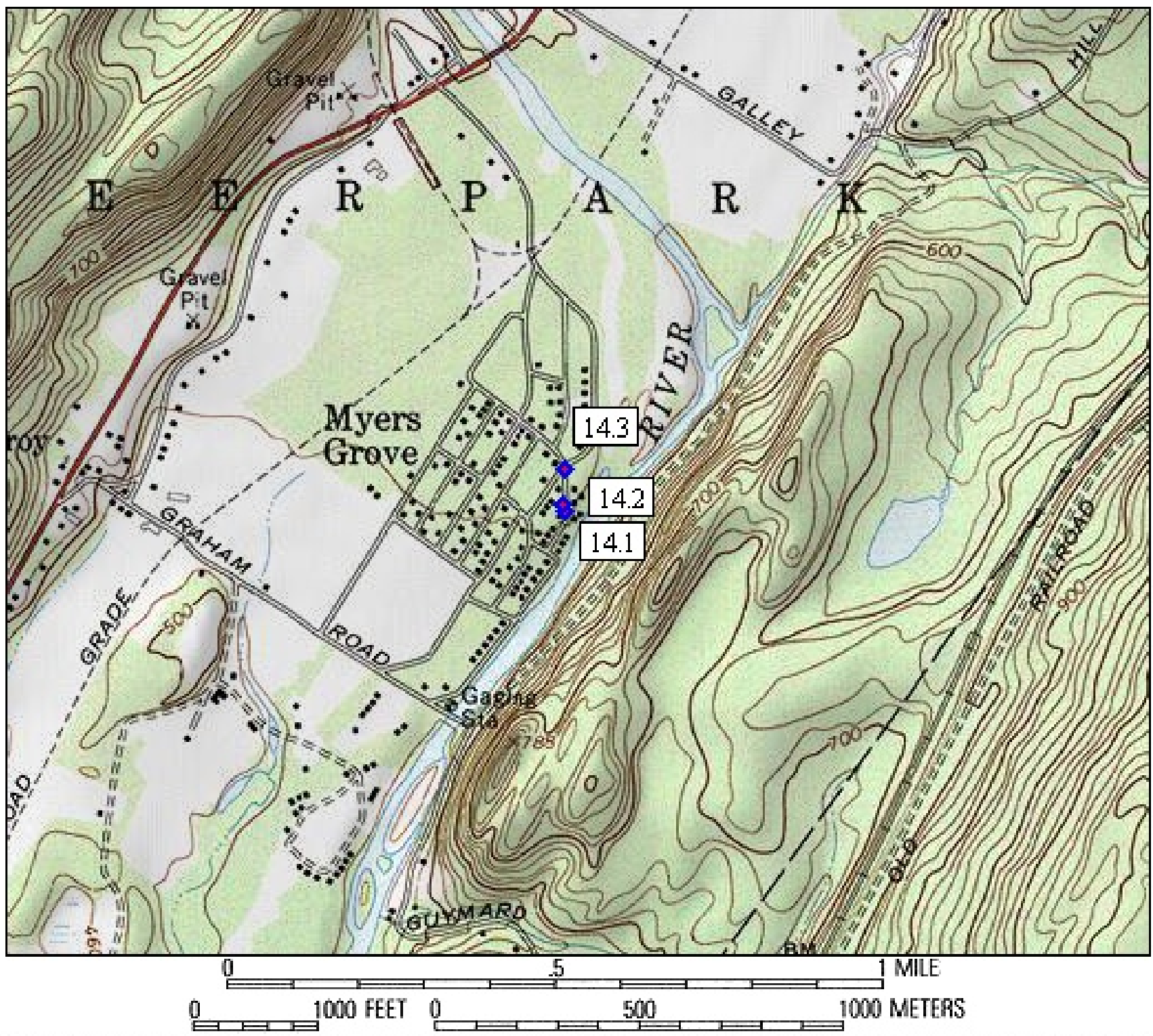

Map created with TOPO!(B) (02003 National Geographic (www.nationalgeographic. com/topo)

Otisville quad map with location of site 14, Neversink River at Avenue E and Grove Street at Myers Grove, N.Y. 


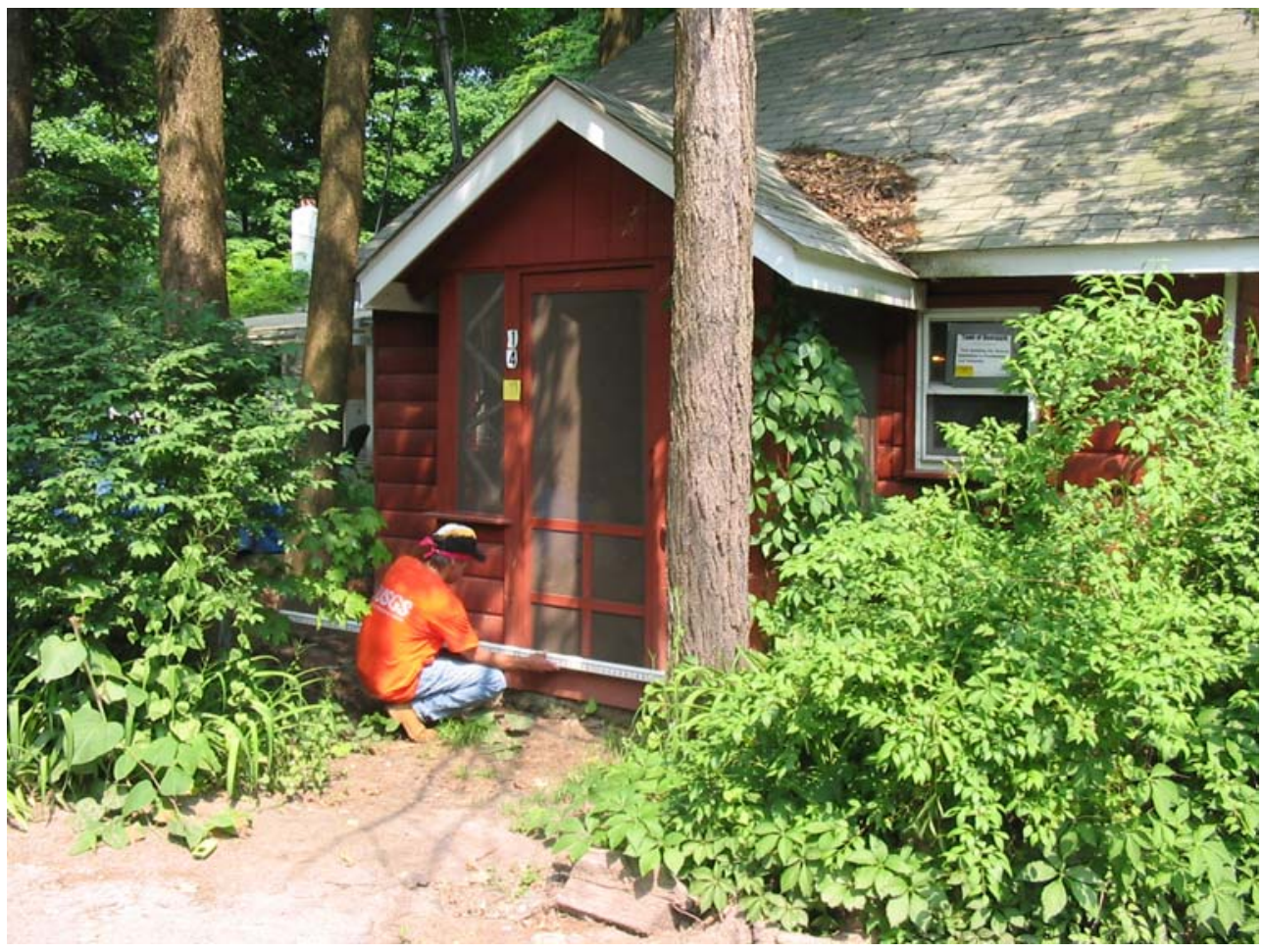

High-water mark 14.1 is a good seed line about 1 foot above the ground, on the landward side of house 14 on Avenue E, on the right bank, at elevation 477.74 feet above NGVD 29 (lat $41^{\circ} 26^{\prime} 44.1^{\prime \prime}$, long $74^{\circ} 35^{\prime} 53.6^{\prime \prime}$ ).

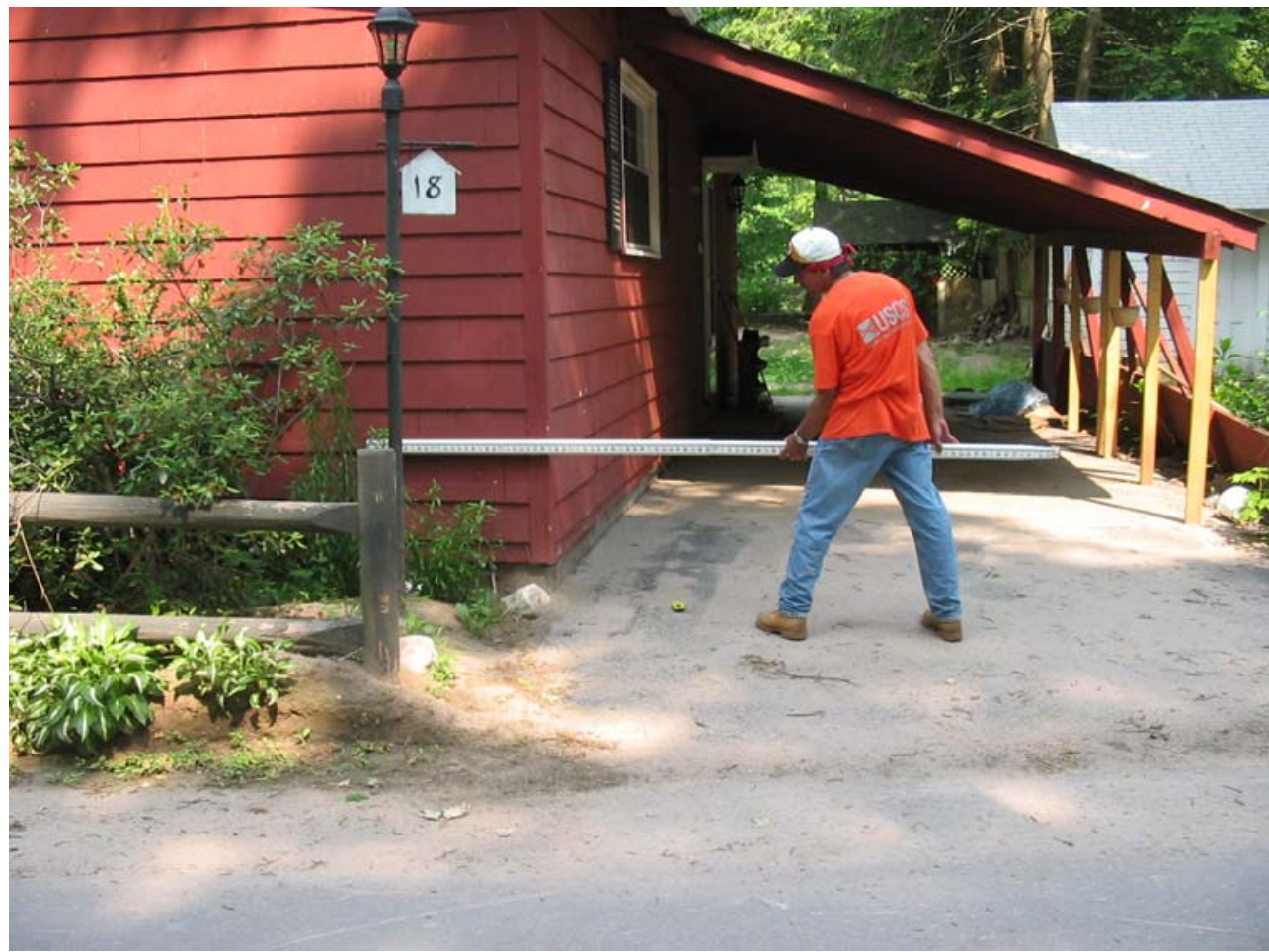

High-water mark 14.2 is a good mud line about 2.5 feet above the ground, on the landward side of house 18 on Avenue E, on the right bank, at elevation 478.72 feet above NGVD 29 (lat $41^{\circ} 26^{\prime} 44.7^{\prime \prime}$, long $74^{\circ} 35^{\prime} 53.8^{\prime \prime}$ ). 


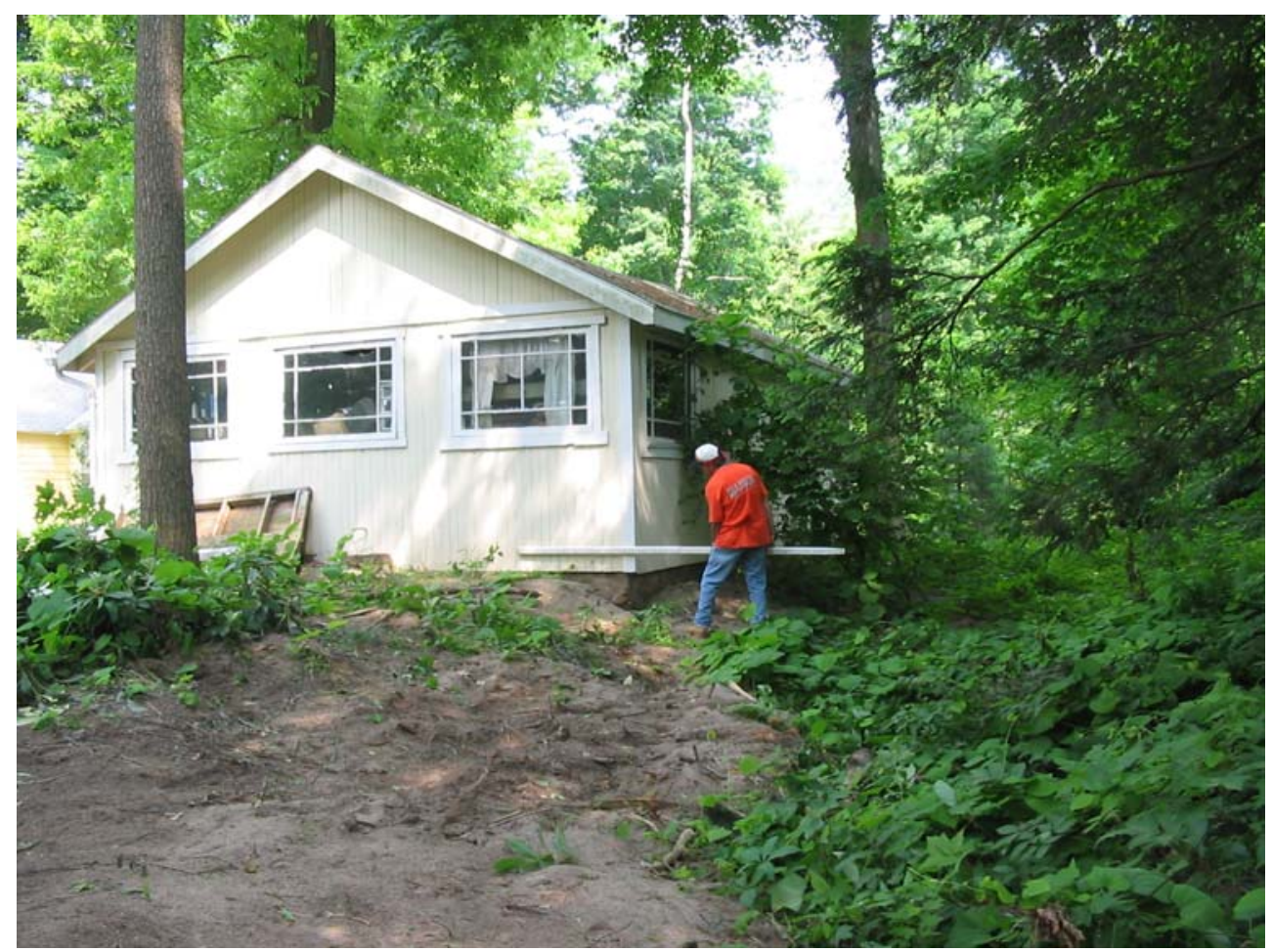

High-water mark 14.3 is a good mud line about 1 foot above the ground, on the landward side of a detached garage downstream from house 14 on Grove Street, on the right bank, at elevation 479.64 feet above NGVD 29 (lat $41^{\circ} 26^{\prime} 47.5^{\prime \prime}$, long $74^{\circ} 35^{\prime}$ 53.6”). 
Page left intentionally blank 


\begin{tabular}{|l|}
\hline \multicolumn{1}{|c|}{ SITE DESCRIPTION } \\
\hline Site 15: Neversink River at Shore Drive at Myers Grove, N.Y. \\
\hline Site Location: Shore Drive, lat $41^{\circ} 26^{\prime} 32.9^{\prime}$, long $74^{\circ}$ 36' 04.4’, NAD 83 \\
\hline Town of Deerpark, Orange County, N.Y. \\
\hline Otisville USGS 7.5' Topographic Quadrangle \\
\hline High-Water Marks: Three high-water marks were surveyed: three mud lines. \\
\hline Photos and GPS readings were taken at each high-water mark. Field notes are filed at the USGS office in Troy, N.Y. \\
\hline Marks were surveyed and photos taken by G.D. Firda and A.M. Gearwar on June 9, 2005. \\
\hline $\begin{array}{l}\text { High-water-mark elevations were surveyed from a reference mark that is the USGS stream-gaging station } 01437500 \text { reference } \\
\text { mark RM 10. Elevation is } 474.72 \text { feet above NGVD 29. To convert to NAVD 88, subtract 0.61 feet from all elevations at this } \\
\text { site. }\end{array}$ \\
\hline
\end{tabular}

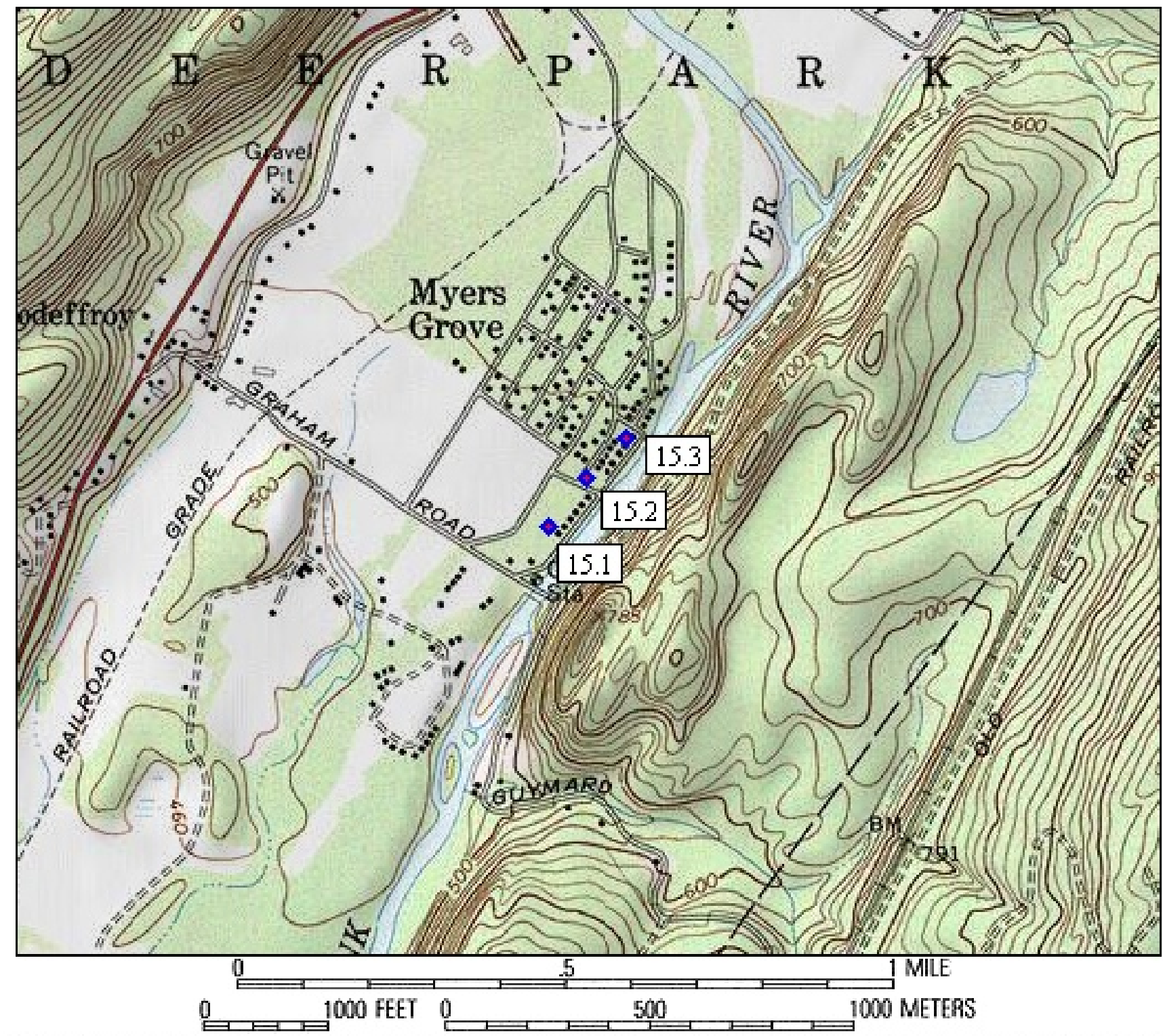

Map created with TOPO!(B) (02003 National Geographic (www.nationalgeographic. com/topo)

Otisville quad map with location of site 15, Neversink River at Shore Drive at Myers Grove, N.Y. 


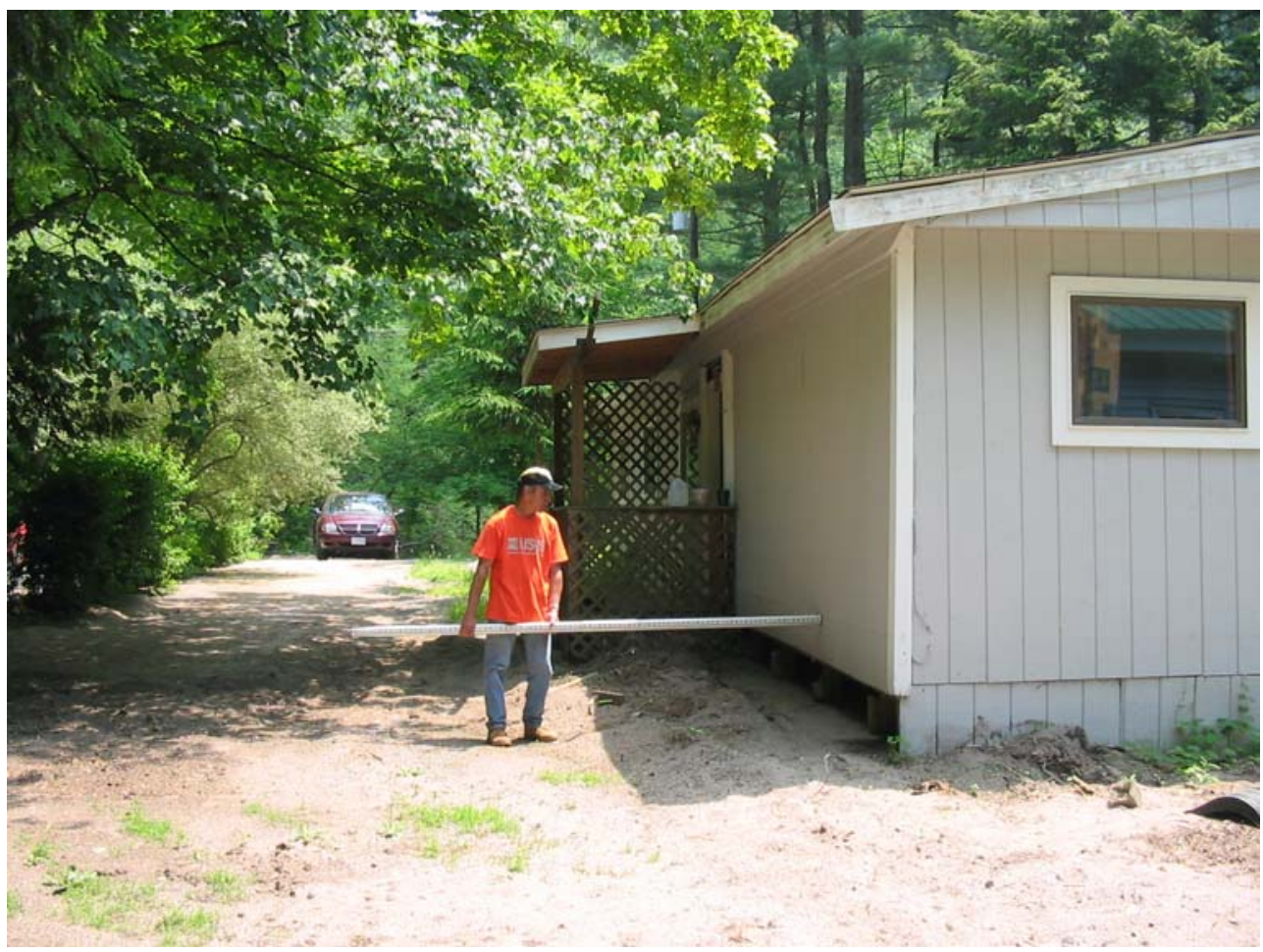

High-water mark 15.1 is an excellent mud line about 2 feet above the ground, on the upstream side of unnumbered house just downstream from house 23 on Shore Drive, on the right bank, at elevation 473.78 feet above NGVD 29 (lat $41^{\circ} 26^{\prime} 32.9^{\prime \prime}$, long $\left.74^{\circ} 36^{\prime} 04.4^{\prime \prime}\right)$.

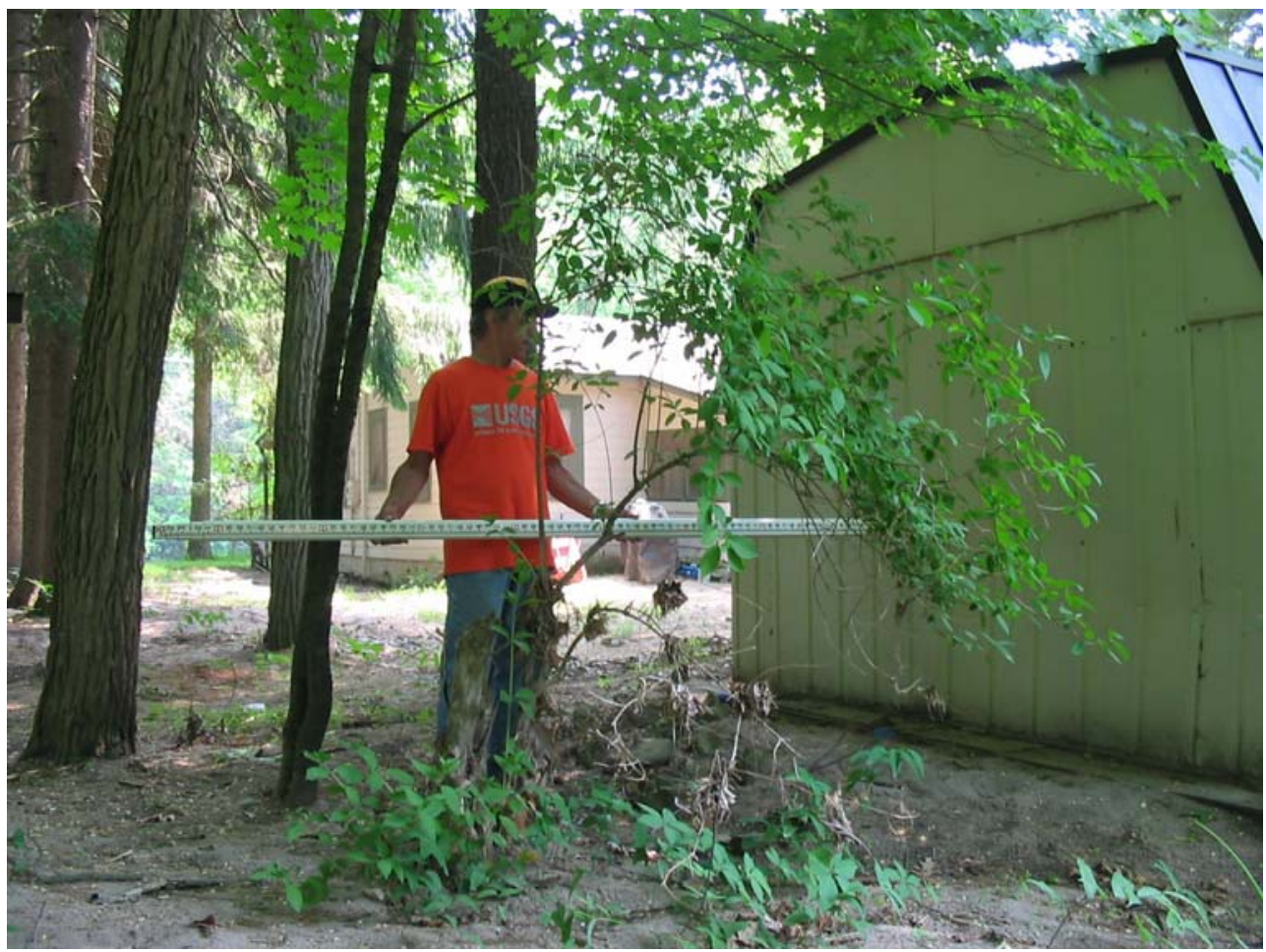

High-water mark 15.2 is a fair mud line about 3 feet above the ground, on the upstream side of a storage shed landward from

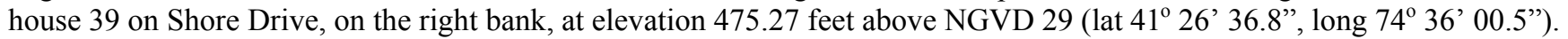




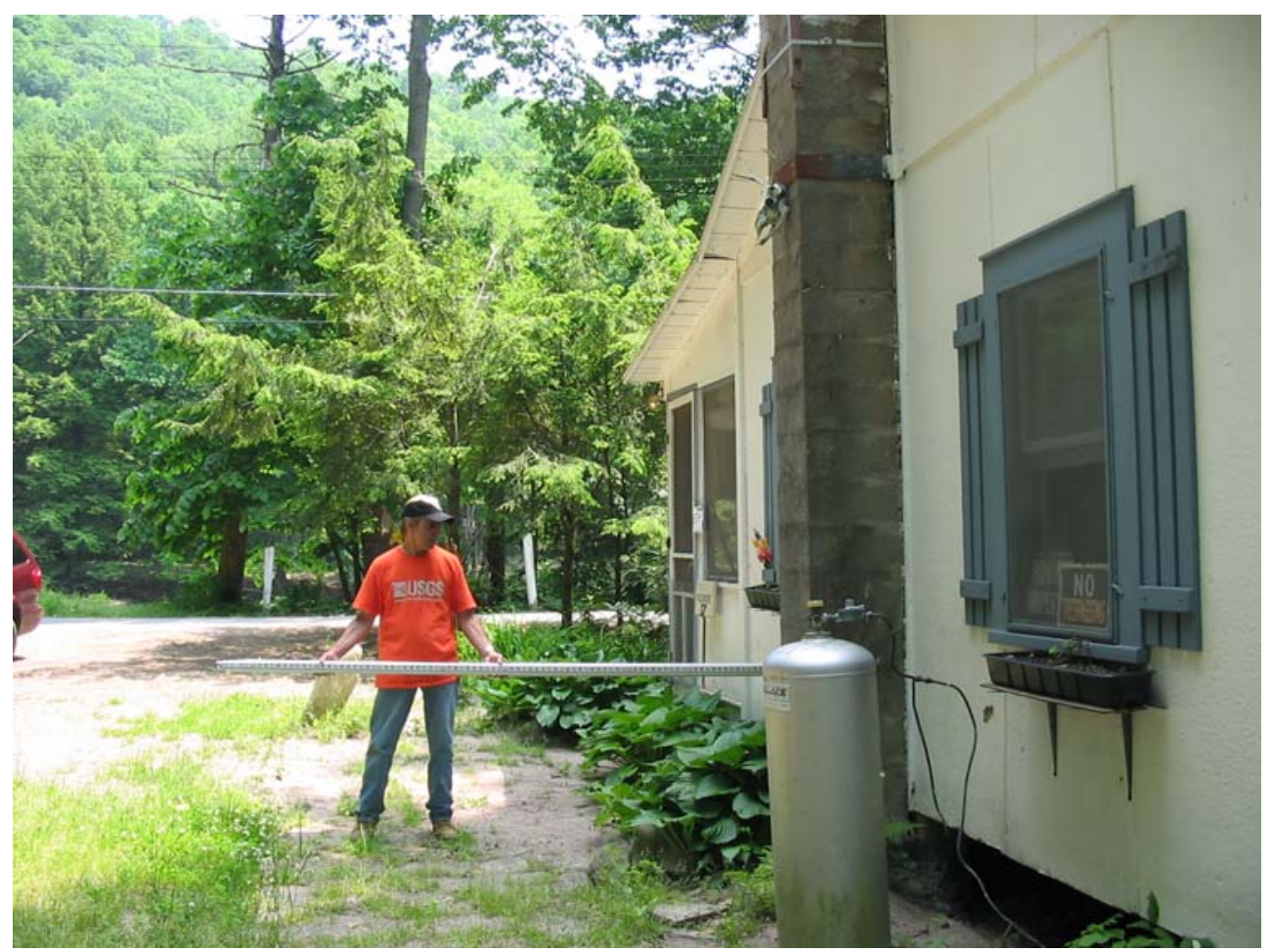

High-water mark 15.3 is a fair seed line about 3 feet above the ground, on the upstream side of house 57 on Shore Drive, on the right bank, at elevation 476.31 feet above NGVD 29 (lat $41^{\circ} 26^{\prime} 39.9^{\prime \prime}$, long $74^{\circ} 35^{\prime} 56.3$ ”). 
Page left intentionally blank 
SITE DESCRIPTION

Site 16: Neversink River at Guymard Turnpike at Myers Grove, N.Y.

Site Location: Bridge on Guymard Turnpike, lat $41^{\circ} 26^{\prime} 27.0^{\prime \prime}$, long $74^{\circ} 36^{\prime} 05.4^{\prime \prime}$, NAD 83

Town of Deerpark, Orange County, N.Y.

Otisville USGS 7.5' Topographic Quadrangle

High-Water Marks: Thirty-one high-water marks were surveyed: 18 seed lines, 12 debris lines, and 1 mud line.

Photos and GPS readings were taken at most high-water marks. Field notes are filed at the USGS office in Troy, N.Y.

Marks were surveyed and photos taken by G.D. Firda, R. Lumia, and B.J. Zatorsky on April 11-12, 2005, G.D. Firda, C.L.

Gazoorian, and R. Lumia on April 19, 2005, and G.D. Firda and A.M. Gearwar on June 9, 2005.

High-water-mark elevations were surveyed from a reference mark that is the USGS stream-gaging station 01437500 reference mark RM 10. Elevation is 474.72 feet above NGVD 29. To convert to NAVD 88, subtract 0.61 feet from all elevations at this site.

Thalweg Elevation: 458.0 feet above NGVD 29

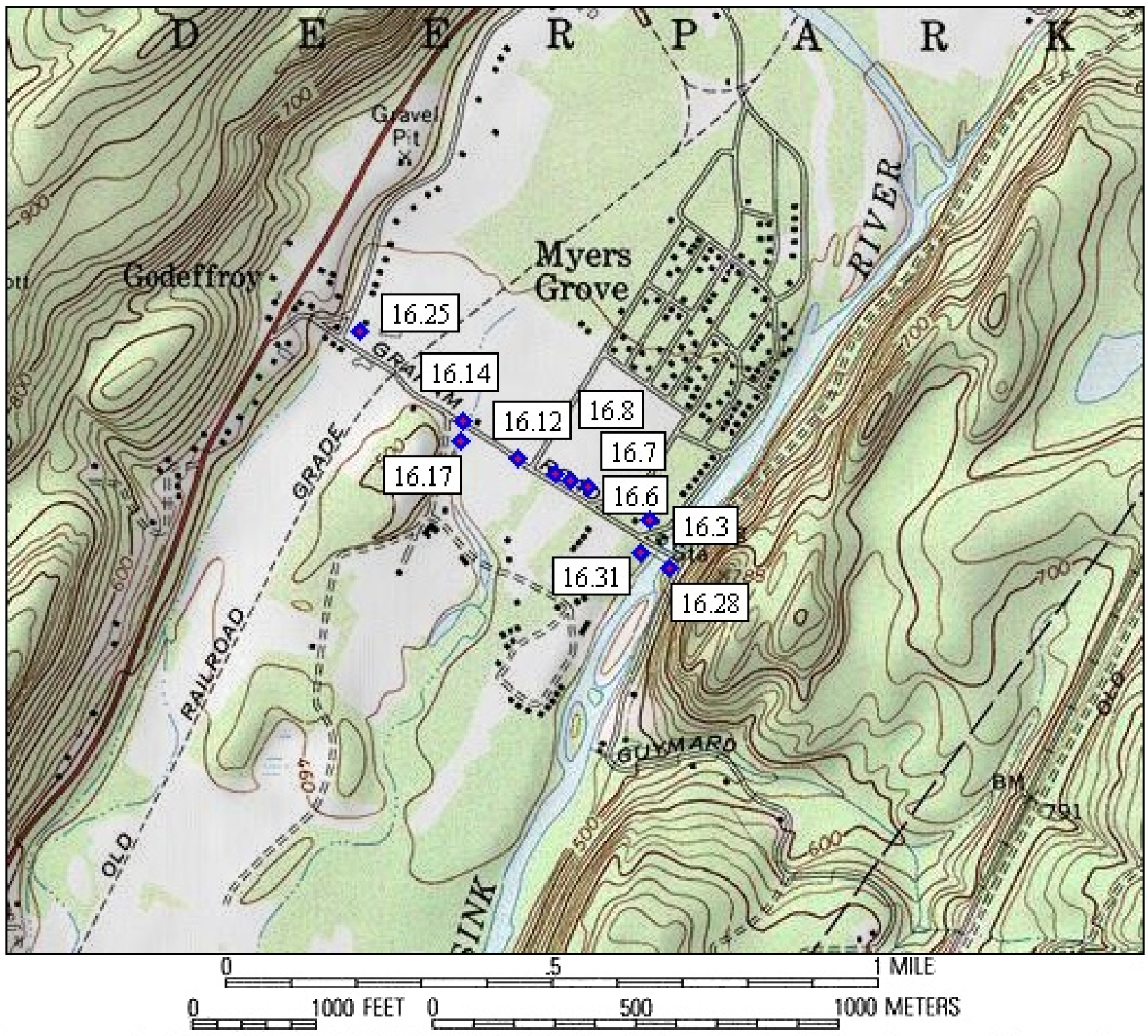

Map created with TOPO! (G2003 National Geographic (www.nationalgeographic.com/topo)

Otisville quad map with location of site 16, Neversink River at Guymard Turnpike at Myers Grove, N.Y. 


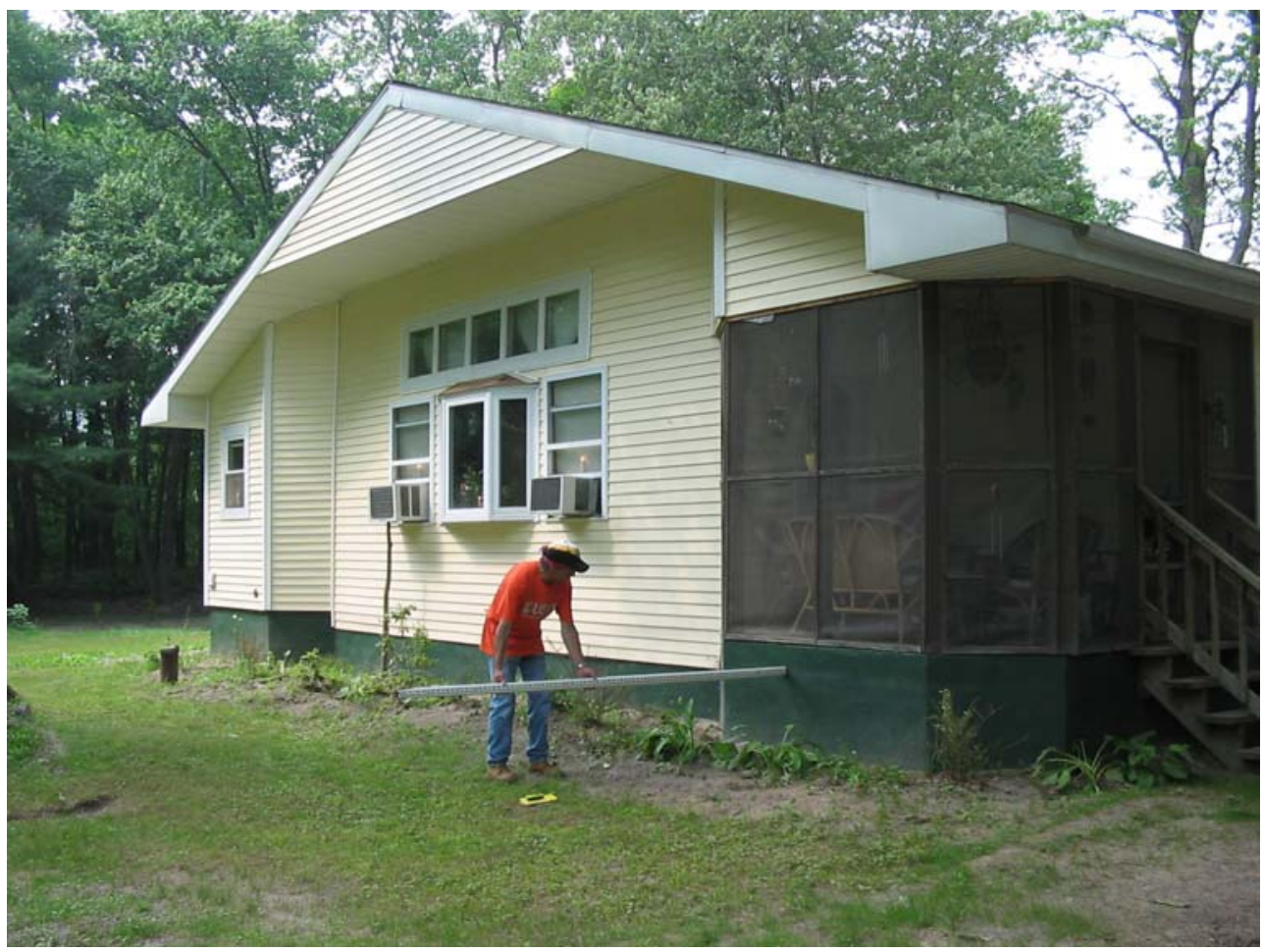

High-water mark 16.3 is a good mud line about 2 feet above the ground, on the downstream side of house 7 on Shore Drive, on the right bank, 155 feet upstream and 75 feet landward from the Guymard Turnpike bridge right abutment, at elevation 473.35 feet above NGVD 29 (lat $41^{\circ} 26^{\prime} 30.2^{\prime \prime}$, long $74^{\circ} 36^{\prime} 06.9^{\prime \prime}$ ).

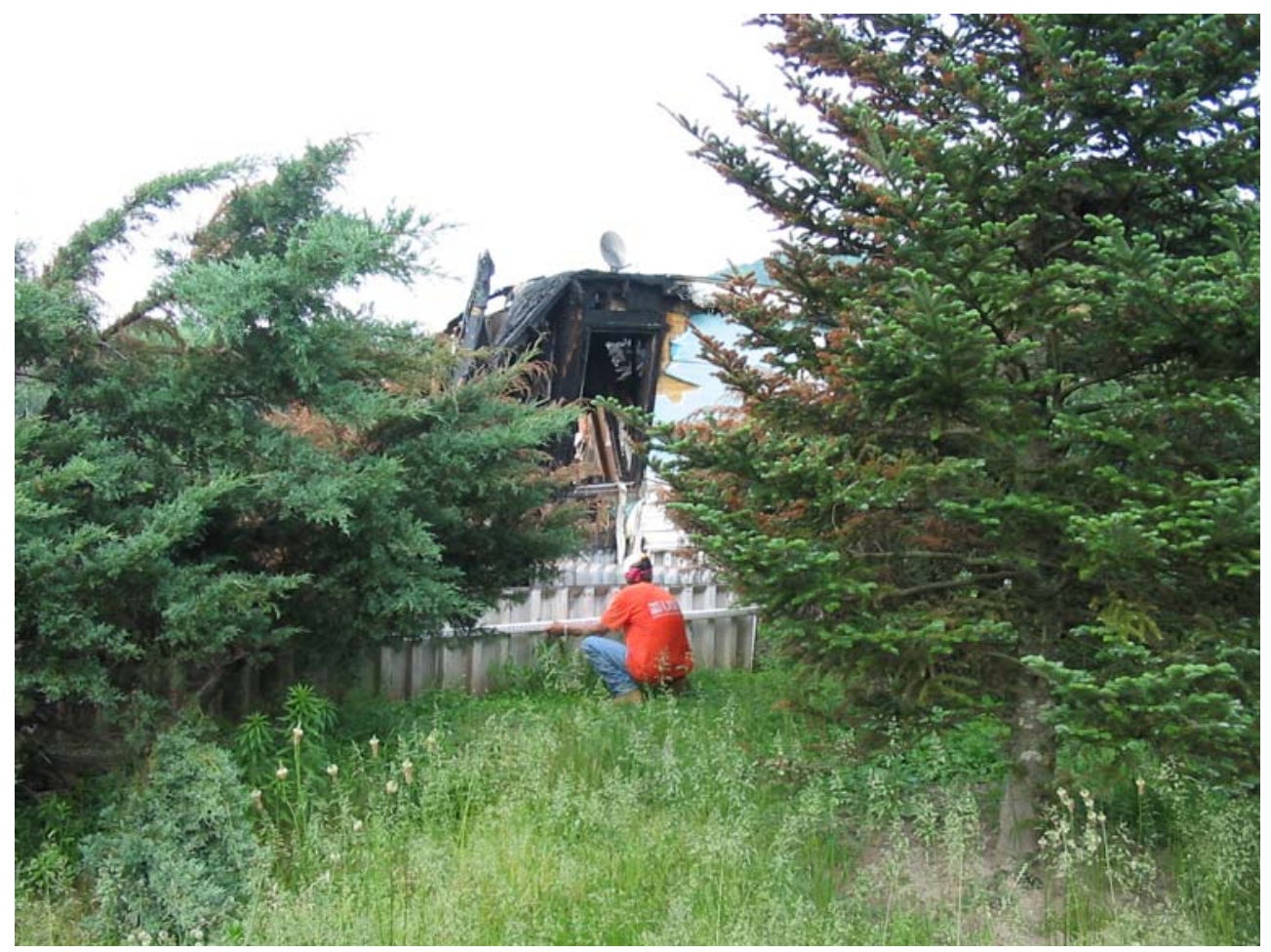

High-water mark 16.6 is an excellent seed line about 2 feet above the ground, on the downstream side of unnumbered house just streamward from house 123 on Guymard Turnpike, on the right bank, 150 feet upstream and 670 feet landward from the Guymard Turnpike bridge right abutment, at elevation 472.81 feet above NGVD 29 (lat $41^{\circ} 26^{\prime} 32.8^{\prime \prime}$, long $74^{\circ} 36^{\prime}$ '13.4”). 


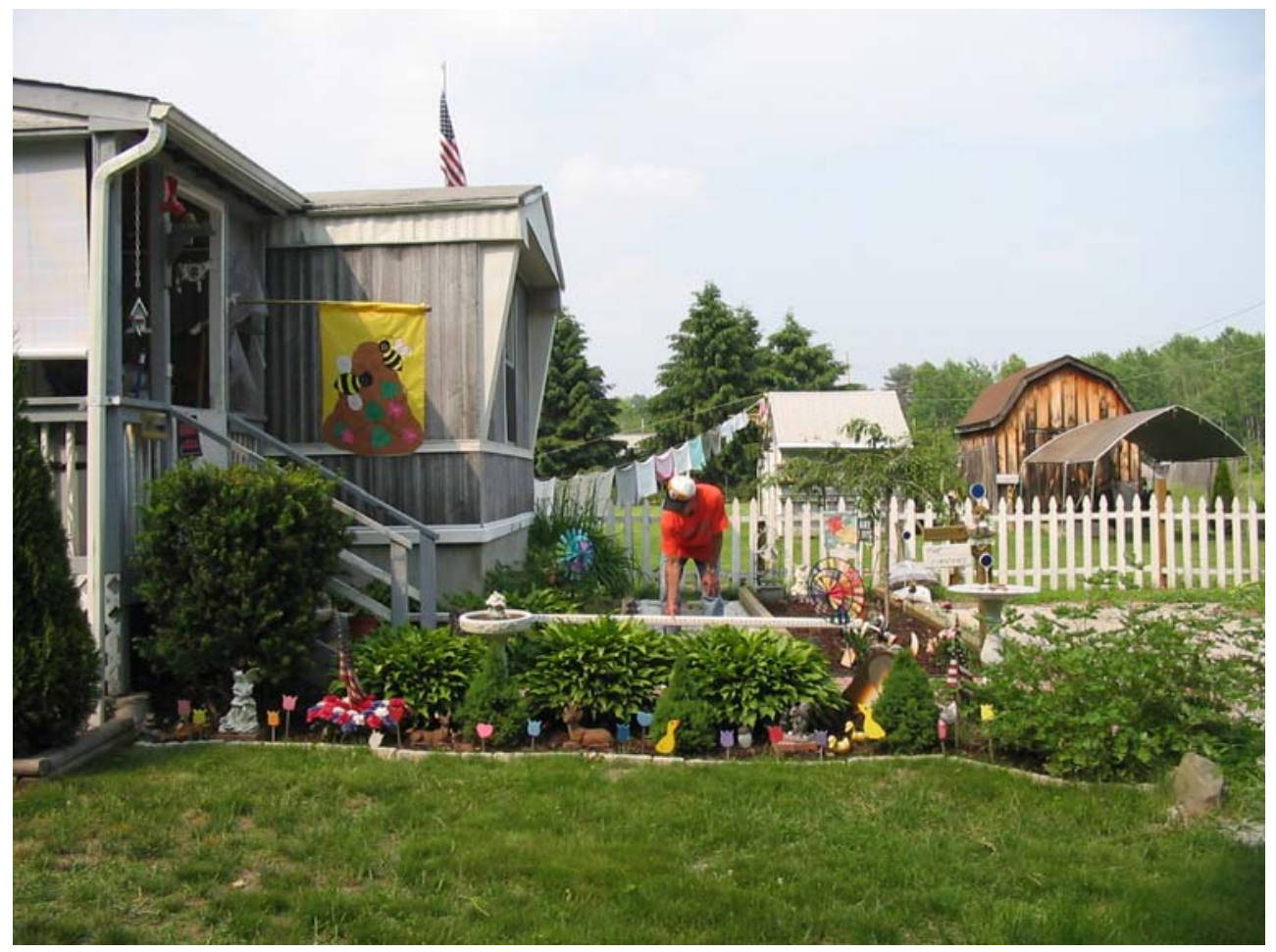

High-water mark 16.7 is a good seed line about 1 foot above the ground, on the downstream side of house 123 on Guymard Turnpike, on the right bank, 90 feet upstream and 815 feet landward from the Guymard Turnpike bridge right abutment, at elevation 472.37 feet above NGVD 29 (lat $41^{\circ} 26^{\prime} 33.3^{\prime \prime}$, long $74^{\circ} 36^{\prime} 15.4^{\prime \prime}$ ).

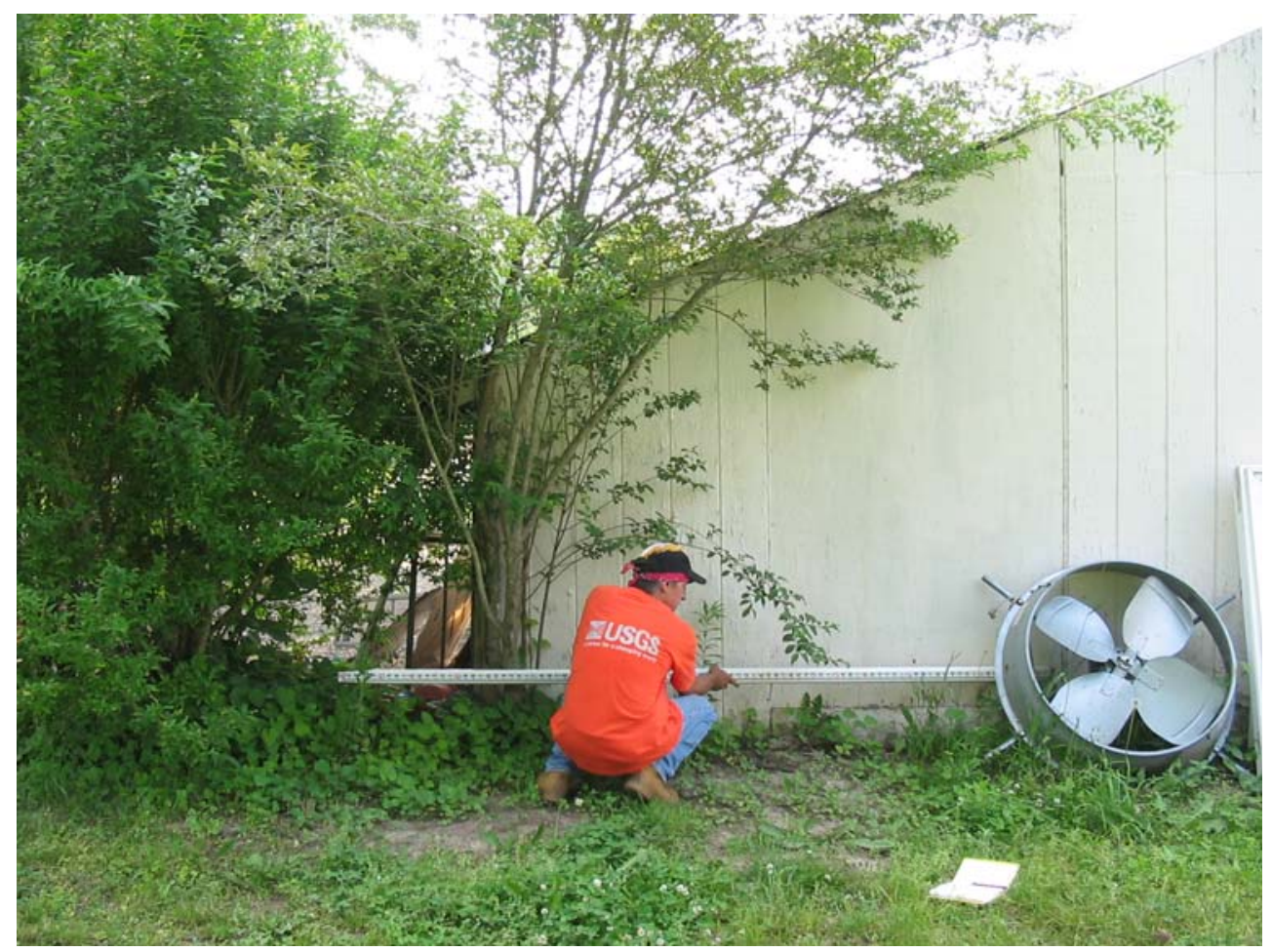

High-water mark 16.8 is an excellent seed line about 1 foot above the ground, on the streamward side of a detached garage streamward from house 119 on Guymard Turnpike, on the right bank, 80 feet upstream and 965 feet landward from the Guymard Turnpike bridge right abutment, at elevation 472.17 feet above NGVD 29 (lat 41 ${ }^{\circ} 26^{\prime} 33.9^{\prime \prime}$, long $74^{\circ} 36^{\prime} 17.1^{\prime \prime}$ ). 


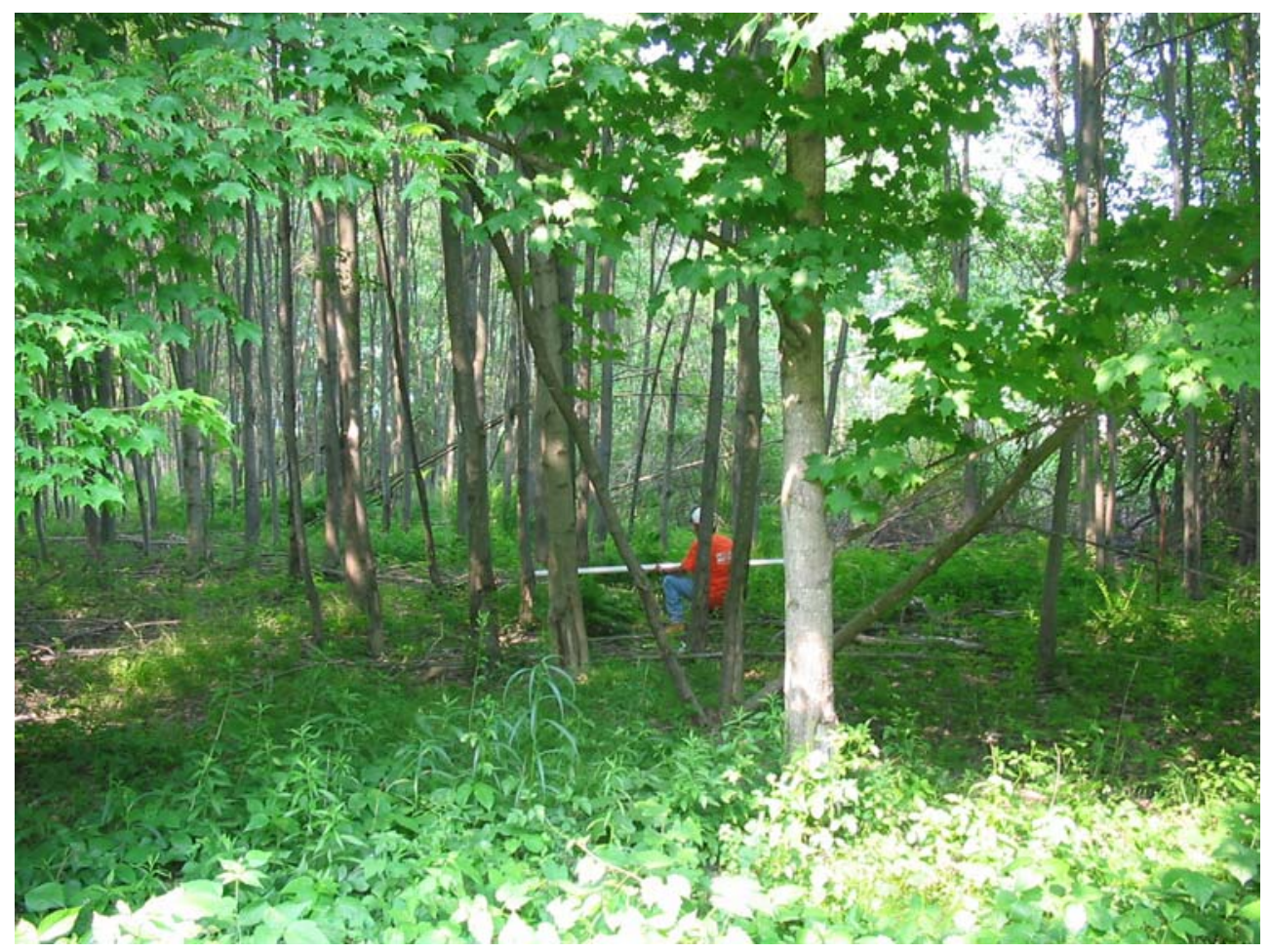

High-water mark 16.12 is an excellent seed line about 2 feet above the ground, on a tree on the right bank, 50 feet upstream and 1,330 feet landward from the Guymard Turnpike bridge right abutment, at elevation 469.61 feet above NGVD 29 (lat $41^{\circ} 26^{\prime}$ $35.2^{\prime \prime}$, long $\left.74^{\circ} 36^{\prime} 21.0^{\prime \prime}\right)$.

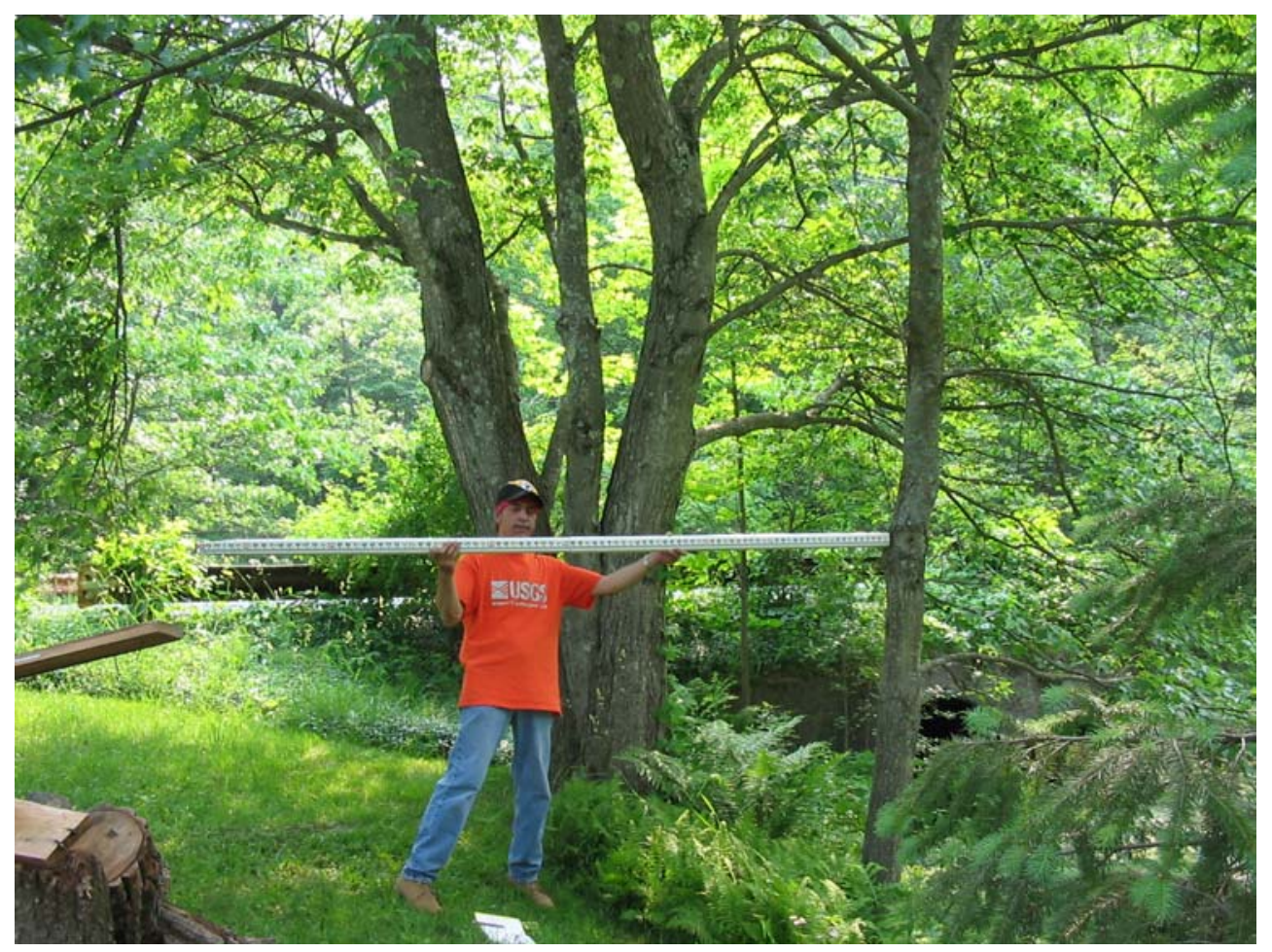

High-water mark 16.14 is an excellent seed line about 6 feet above the ground, on a tree on the right bank, 35 feet upstream and 1,815 feet landward from the Guymard Turnpike bridge right abutment, at elevation 471.27 feet above NGVD 29 (lat $41^{\circ} 26^{\prime}$ $38.1^{\prime \prime}$, long $\left.74^{\circ} 36^{\prime} 26.8^{\prime \prime}\right)$. 
No photos were taken of high-water mark 16.17. High-water mark 16.17 is a fair debris line on the ground, on the right bank, 60 feet downstream and 1,800 feet landward from the Guymard Turnpike bridge right abutment, at elevation 467.50 feet above NGVD 29 (lat $41^{\circ} 26^{\prime} 36.6^{\prime \prime}$, long $74^{\circ} 36^{\prime} 27.0^{\prime \prime}$ ).

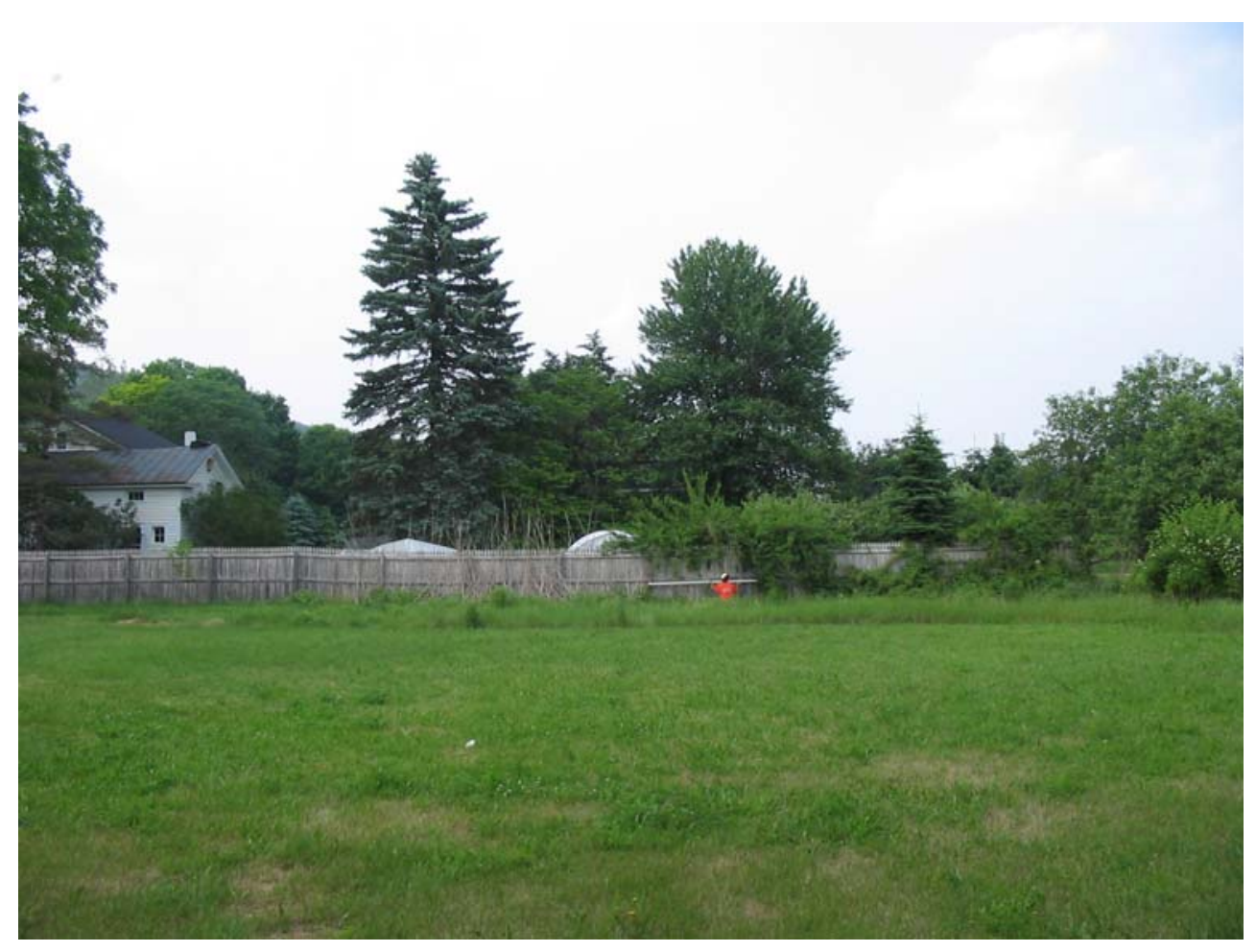

High-water mark 16.25 is an excellent seed line about 3 feet above the ground, on the downstream side of a fence, on the right bank, 150 feet upstream and 2,895 feet landward from the Guymard Turnpike bridge right abutment, at elevation 473.98 feet above NGVD 29 (lat $41^{\circ} 26^{\prime} 45.3^{\prime \prime}$, long $74^{\circ} 36^{\prime} 37.7^{\prime \prime}$ ).

No photos were taken of high-water mark 16.28. High-water mark 16.28 is a fair debris line on the ground, on the left bank, 30 feet downstream and 30 feet landward from the Guymard Turnpike bridge left abutment, at elevation 472.00 feet above NGVD 29 (lat $41^{\circ} 26^{\prime} 26.4^{\prime \prime}$, long $\left.74^{\circ} 36^{\prime} 04.8^{\prime \prime}\right)$.

No photos were taken of high-water mark 16.31. High-water mark 16.31 is a poor seed line about 3 feet above the ground, on a tree on the right bank, 20 feet downstream and 100 feet landward from the Guymard Turnpike bridge right abutment, at elevation 472.14 feet above NGVD 29 (lat $41^{\circ} 26^{\prime} 27.6^{\prime \prime}$, long $74^{\circ} 36^{\prime} 07.8^{\prime \prime}$ ). 
Page left intentionally blank 


\begin{tabular}{|l|}
\hline \multicolumn{1}{|c|}{ SITE DESCRIPTION } \\
\hline Site 17: Neversink River at American Family Campground at Godeffroy, N.Y. \\
\hline Site Location: American Family Campground, lat 41 ${ }^{\circ} 26^{\prime} 27.8^{\prime \prime}$, long $74^{\circ} 36^{\prime} 12.1^{\prime \prime}$, NAD 83 \\
\hline Town of Deerpark, Orange County, N.Y. \\
\hline Otisville USGS 7.5' Topographic Quadrangle \\
\hline High-Water Marks: Four high-water marks were surveyed: three mud lines and one seed line. \\
\hline Photos and GPS readings were taken at each high-water mark. Field notes are filed at the USGS office in Troy, N.Y. \\
\hline Marks were surveyed and photos taken by G.D. Firda and A.M. Gearwar on June 10, 2005. \\
\hline $\begin{array}{l}\text { High-water-mark elevations were surveyed from a reference mark that is the USGS stream-gaging station } 01437500 \text { reference } \\
\text { mark RM 10. Elevation is } 474.72 \text { feet above NGVD 29. To convert to NAVD 88, subtract } 0.61 \text { feet from all elevations at this } \\
\text { site. }\end{array}$ \\
\hline
\end{tabular}

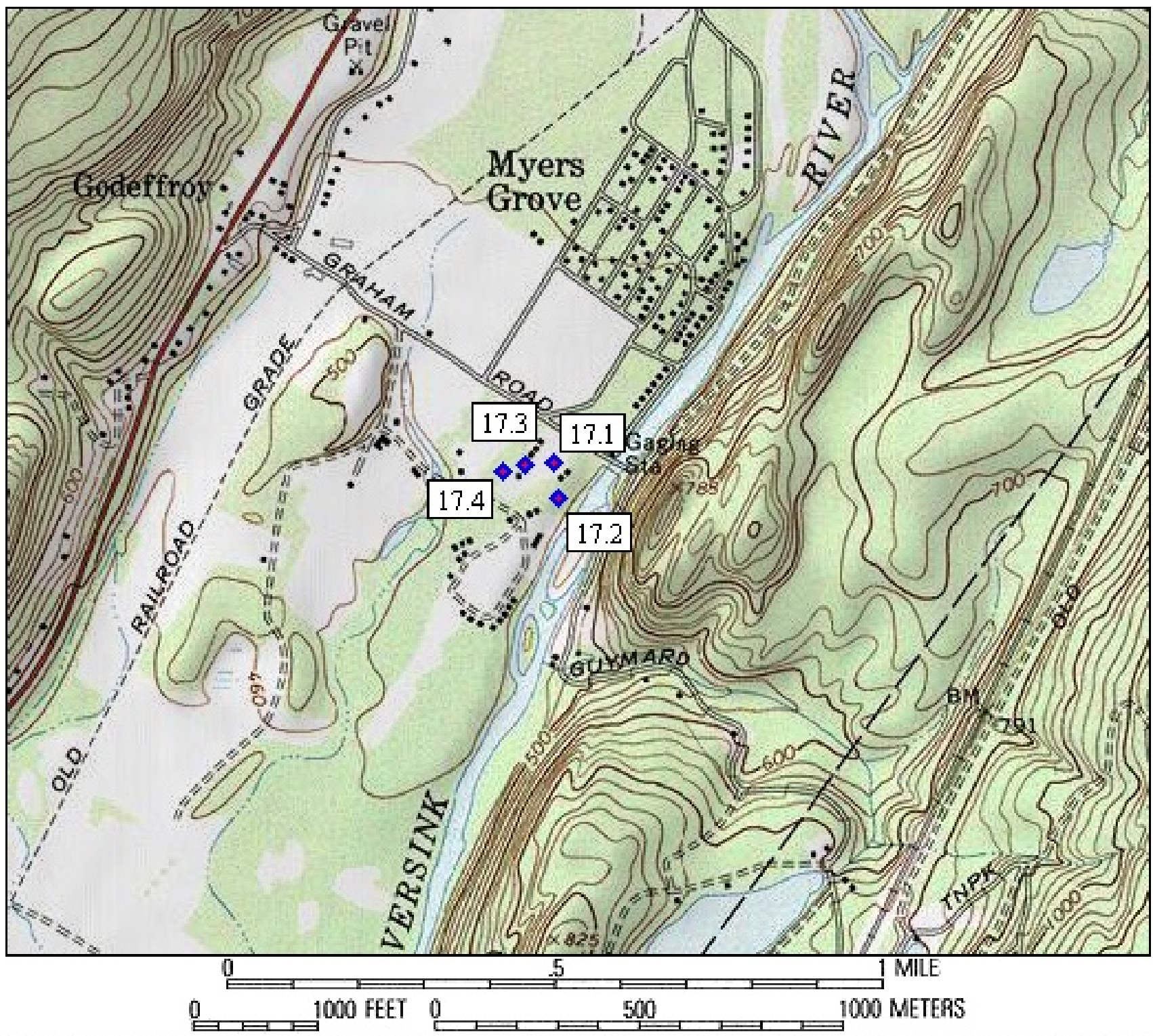

Map created with TOPO!(B) (02003 National Geographic (www.nationalgeographic. com/topo)

Otisville quad map with location of site 17, Neversink River at American Family Campground at Godeffroy, N.Y. 


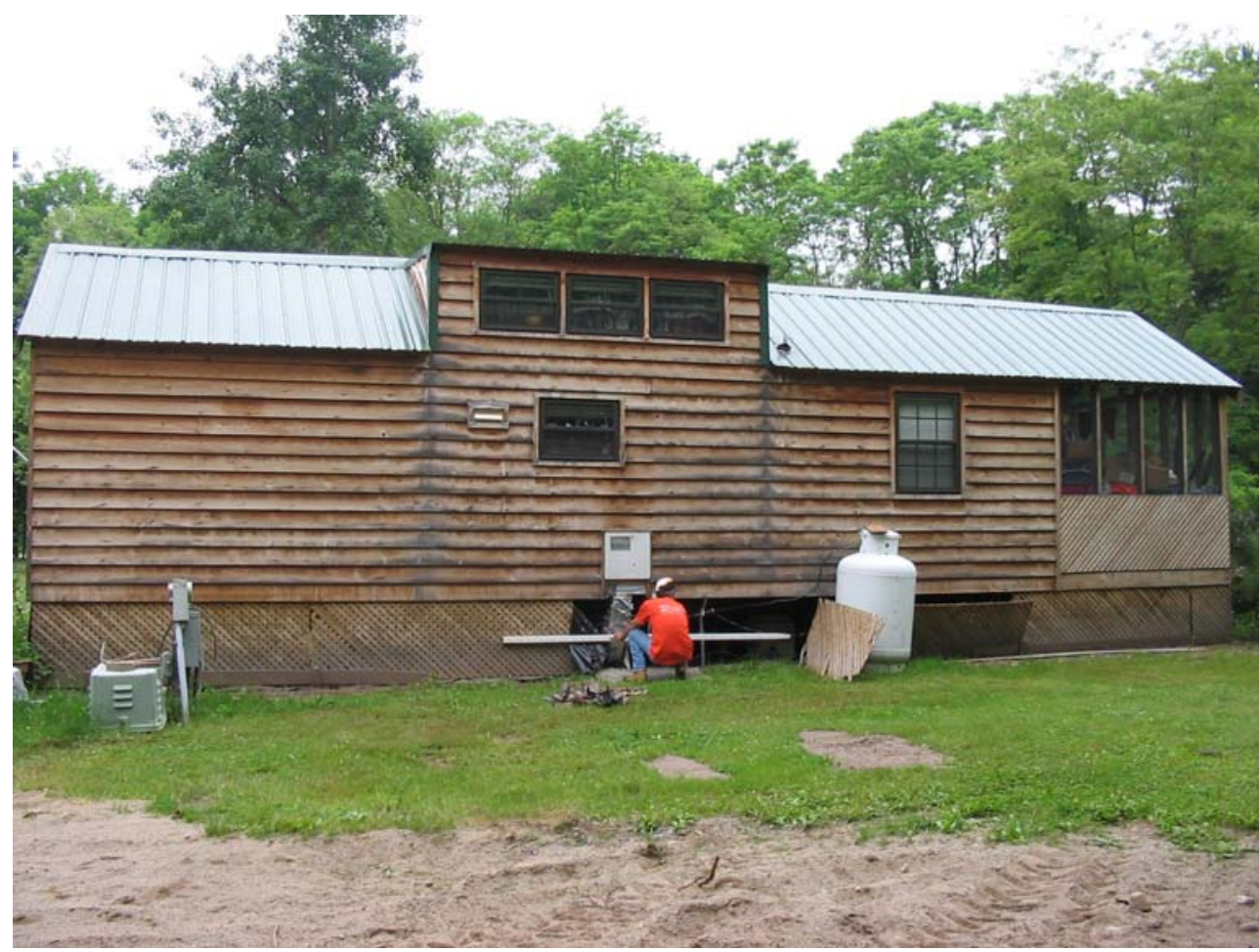

High-water mark 17.1 is a good mud line about 1 foot above the ground, on the streamward side of a cabin located on campsite 53, on the right bank, at elevation 470.55 feet above NGVD 29 (lat $41^{\circ} 26^{\prime} 27.8^{\prime \prime}$, long $74^{\circ} 36^{\prime} 12.1^{\prime \prime}$ ).

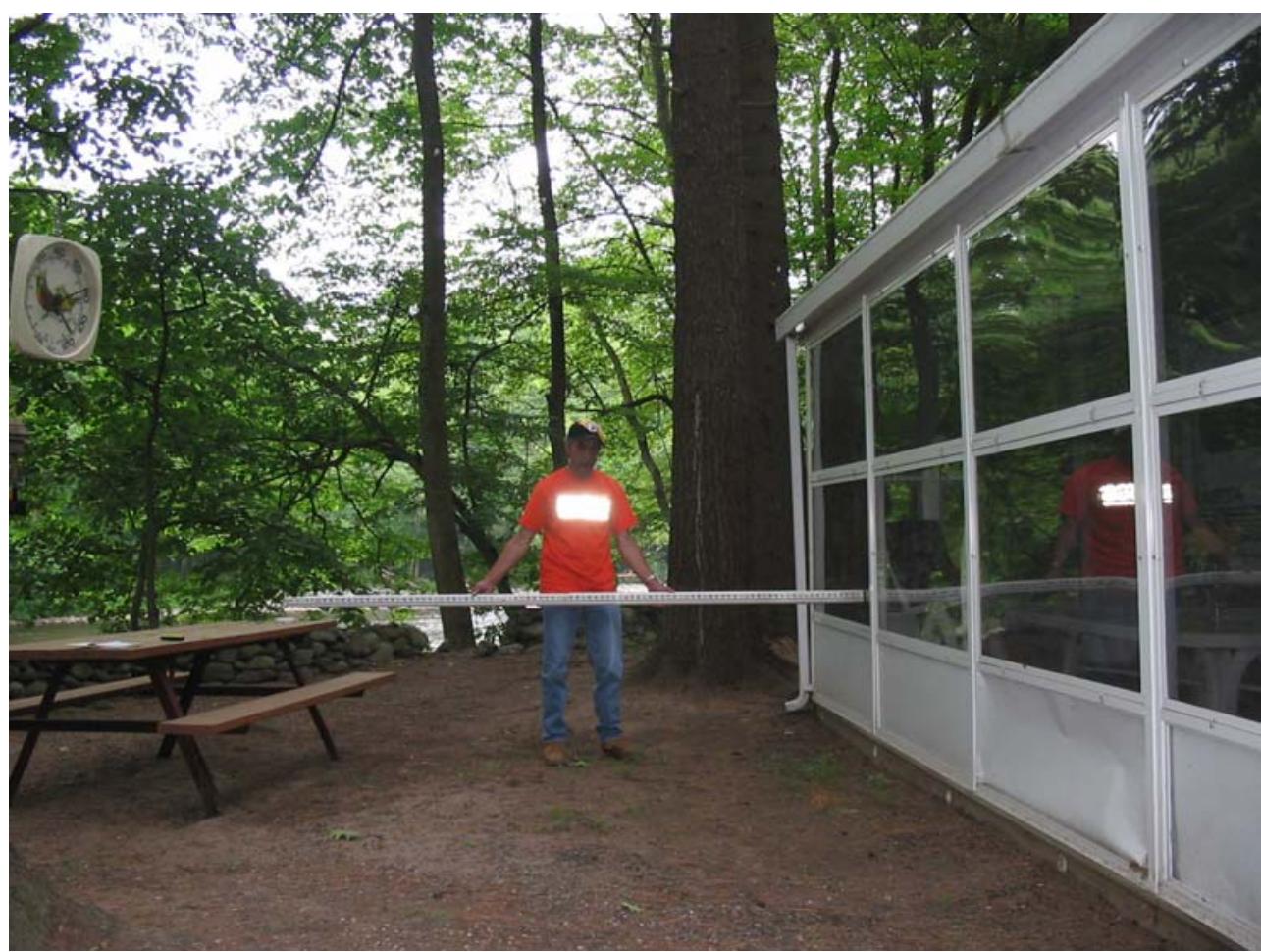

High-water mark 17.2 is a good mud line about 3 feet above the ground, on the streamward side of a cabin located on campsite 58 , on the right bank, at elevation 471.22 feet above NGVD 29 (lat $41^{\circ} 26^{\prime} 25.0^{\prime \prime}$, long $74^{\circ} 36^{\prime} 11.6^{\prime \prime}$ ). 


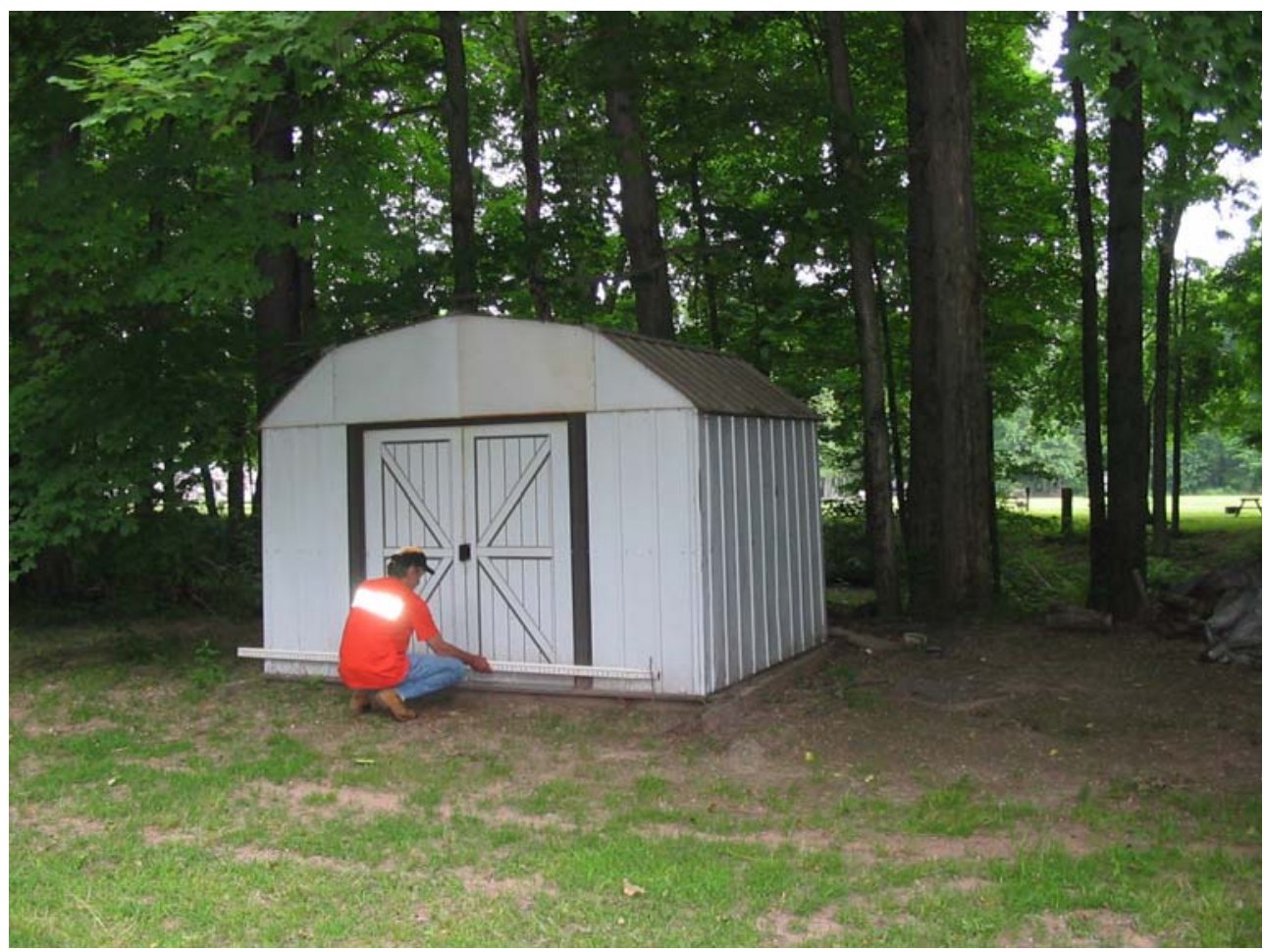

High-water mark 17.3 is a good seed line about 1 foot above the ground, on the streamward side of a storage shed located on campsite 43, on the right bank, at elevation 469.43 feet above NGVD 29 (lat $41^{\circ} 26^{\prime} 27.6^{\prime \prime}$, long $74^{\circ} 36^{\prime} 15.1^{\prime \prime}$ ).

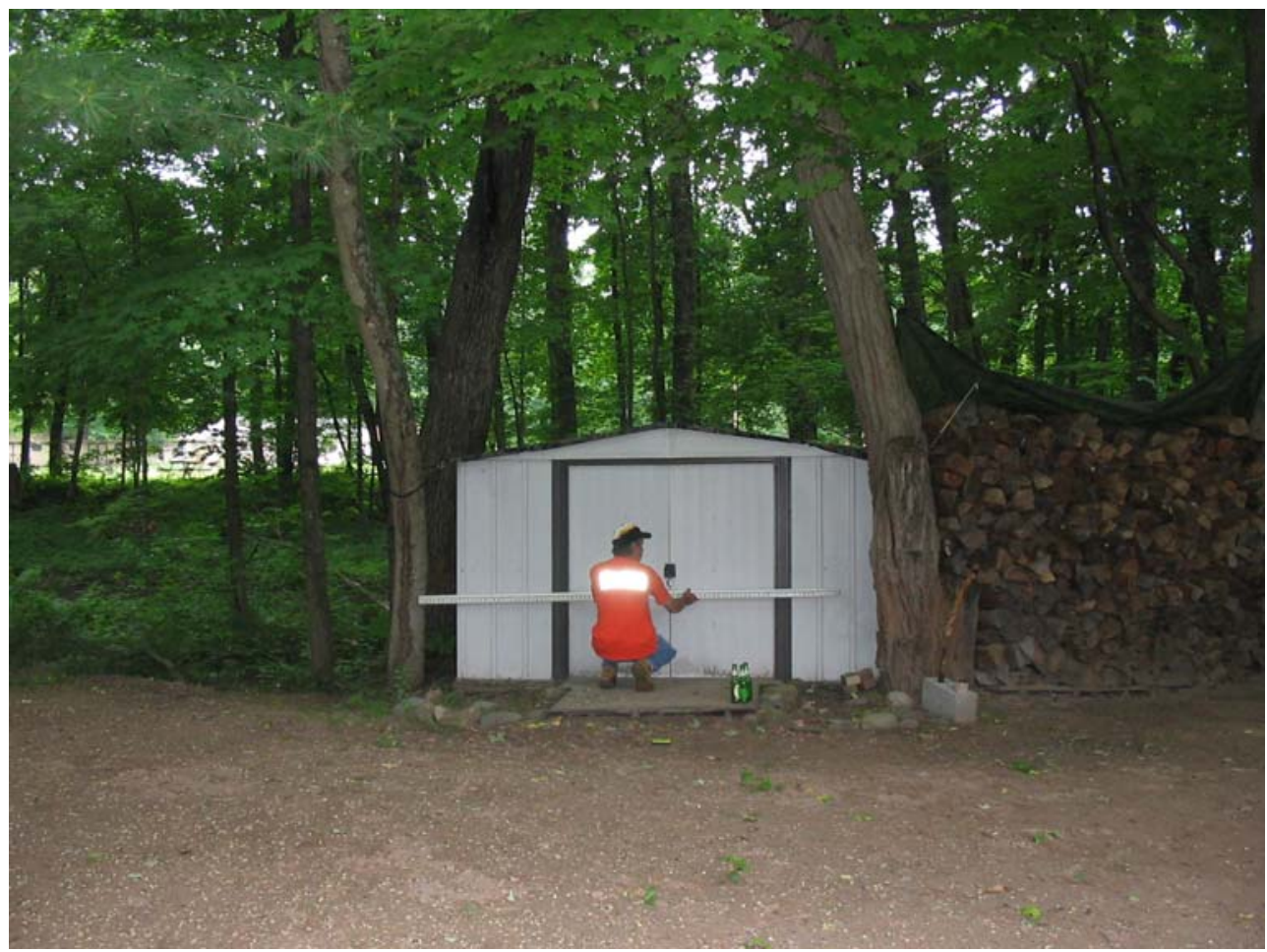

High-water mark 17.4 is an excellent mud line about 2 feet above the ground, on the streamward side of a storage shed located on campsite 37, on the right bank, at elevation 468.90 feet above NGVD 29 (lat $41^{\circ} 26^{\prime} 27.0^{\prime \prime}$, long $74^{\circ} 36^{\prime} 17.4^{\prime \prime}$ ). 
Page left intentionally blank 


\section{SITE DESCRIPTION}

Site 18: Neversink River at County Route 80 (Neversink Drive) at Huguenot, N.Y.

Site Location: Bridge on County Route 80, lat $41^{\circ} 24^{\prime} 24.0^{\prime \prime}$, long $74^{\circ} 38^{\prime} 02.4^{\prime \prime}$, NAD 83

Town of Deerpark, Orange County, N.Y.

Port Jervis North USGS 7.5' Topographic Quadrangle

High-Water Marks: Five high-water marks were surveyed: five seed lines.

Photos and GPS readings were taken at each high-water mark. Field notes are filed at the USGS office in Troy, N.Y.

Marks were surveyed and photos taken by G.D. Firda, C.L. Gazoorian, and R. Lumia on April 18, 2005, and G.D. Firda and

A.M. Gearwar on June 8, 2005.

High-water-mark elevations were surveyed from a reference mark that is a chiseled $\mathrm{X}$ on the northwest corner of the concrete curbing of the Neversink Drive bridge over the Neversink River. This is RM 10 in the Town of Deerpark FEMA flood-

insurance study. Elevation is 458.90 feet above NGVD 29. To convert to NAVD 88, subtract 0.59 feet from all elevations at this site.

Thalweg Elevation: 425.5 feet above NGVD 29.

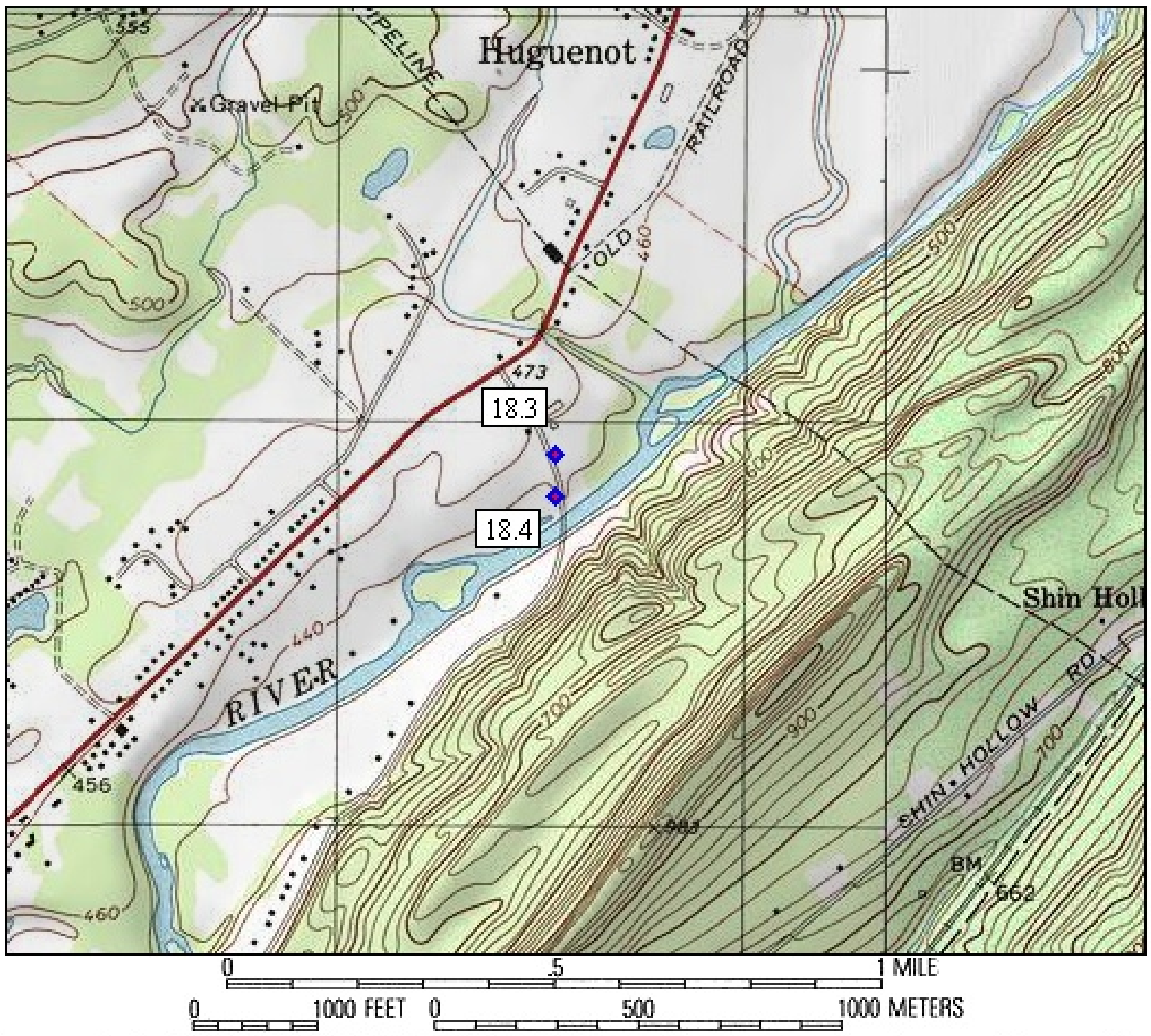

Map created with TOPO!(B) (G003 National Geographic (www.nationalgeographic.com/topo)

Port Jervis North quad map with location of site 18, Neversink River at County Route 80 (Neversink Drive) at Huguenot, N.Y. 


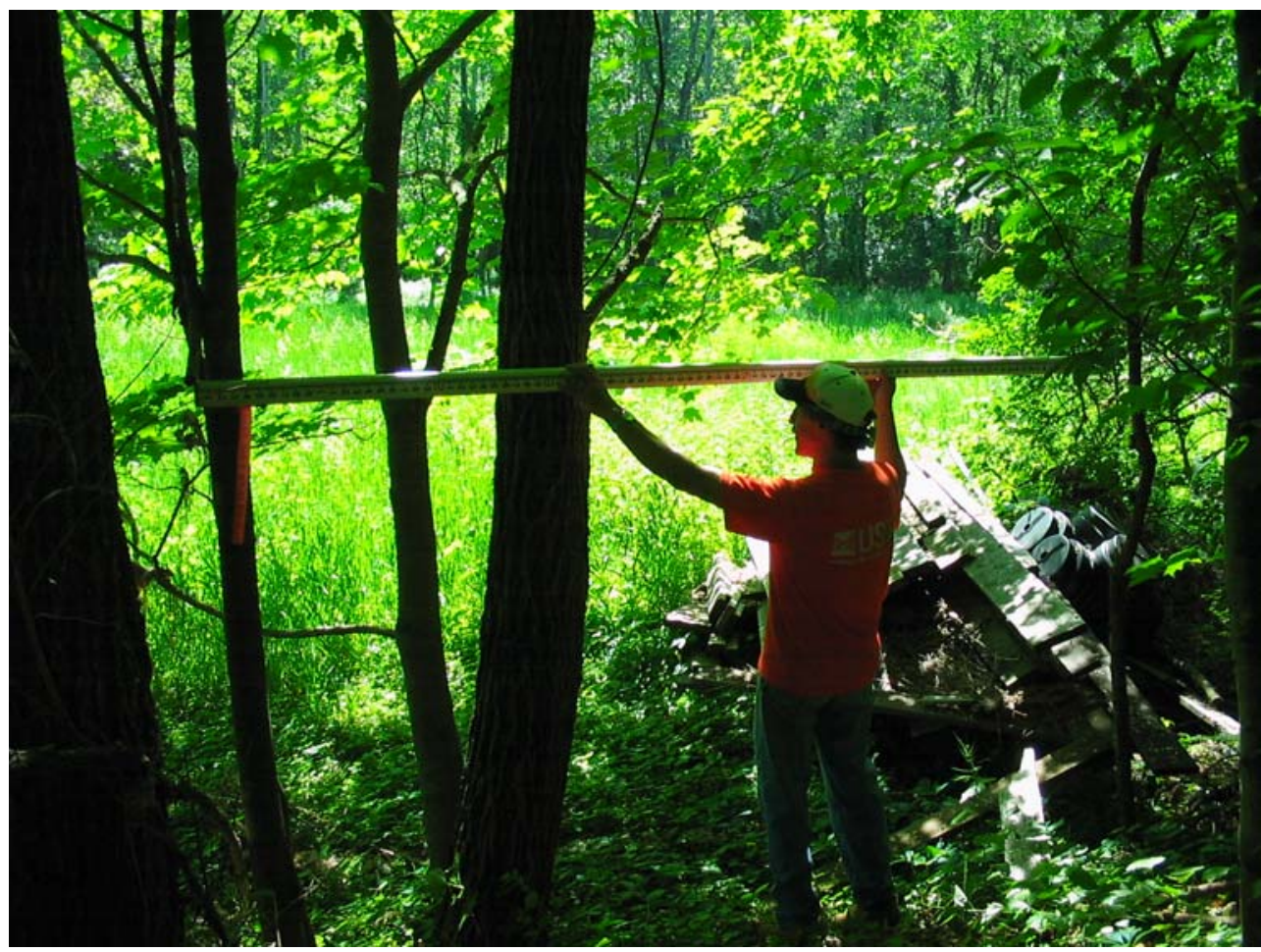

High-water mark 18.3 is an excellent seed line about 6 feet above the ground, on a tree on the right bank, 30 feet upstream from the Neversink Drive bridge, at elevation 446.55 feet above NGVD 29 (lat $41^{\circ} 24^{\prime} 29.5^{\prime \prime}$, long $74^{\circ} 38^{\prime} 03.6^{\prime \prime}$ ).

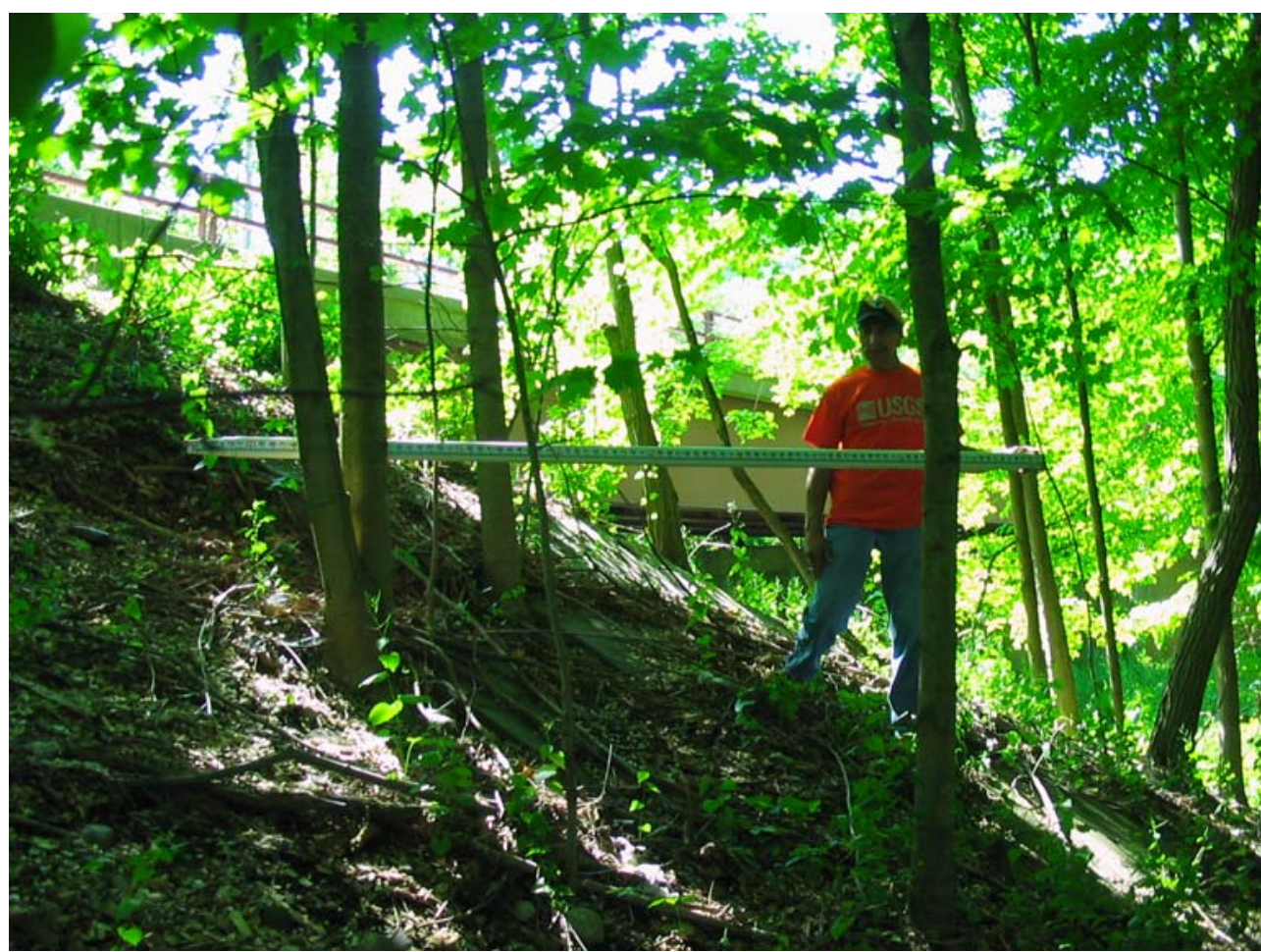

High-water mark 18.4 is a good seed line about 2 feet above the ground, on a tree on the right bank, 25 feet downstream from the Neversink Drive bridge, at elevation 445.05 feet above NGVD 29 (lat $41^{\circ} 24^{\prime} 26.2^{\prime \prime}$, long $74^{\circ} 38^{\prime} 03.6^{\prime \prime}$ ). 


\begin{tabular}{|l|}
\hline \multicolumn{1}{|c|}{ SITE DESCRIPTION } \\
\hline Site 19: Neversink River at Riverdale Road at Huguenot, N.Y. \\
\hline Site Location: Riverdale Road, lat $41^{\circ} 23^{\prime}$ 59.5', long $74^{\circ} 38^{\prime} 40.8^{\prime \prime}$, NAD 83 \\
\hline Town of Deerpark, Orange County, N.Y. \\
\hline Port Jervis North USGS 7.5' Topographic Quadrangle \\
\hline High-Water Marks: Three high-water marks were surveyed: two mud lines and one seed line. \\
\hline Photos and GPS readings were taken at each high-water mark. Field notes are filed at the USGS office in Troy, N.Y. \\
\hline Marks were surveyed and photos taken by G.D. Firda and A.M. Gearwar on June 8, 2005. \\
\hline $\begin{array}{l}\text { High-water-mark elevations were surveyed from a reference mark that is a chiseled X on the northwest corner of the concrete } \\
\text { curbing of the Neversink Drive bridge over the Neversink River. This is RM } 10 \text { in the Town of Deerpark FEMA flood- } \\
\text { insurance study. Elevation is 458.90 feet above NGVD 29. To convert to NAVD 88, subtract } 0.60 \text { feet from all elevations at } \\
\text { this site. }\end{array}$ \\
\hline
\end{tabular}

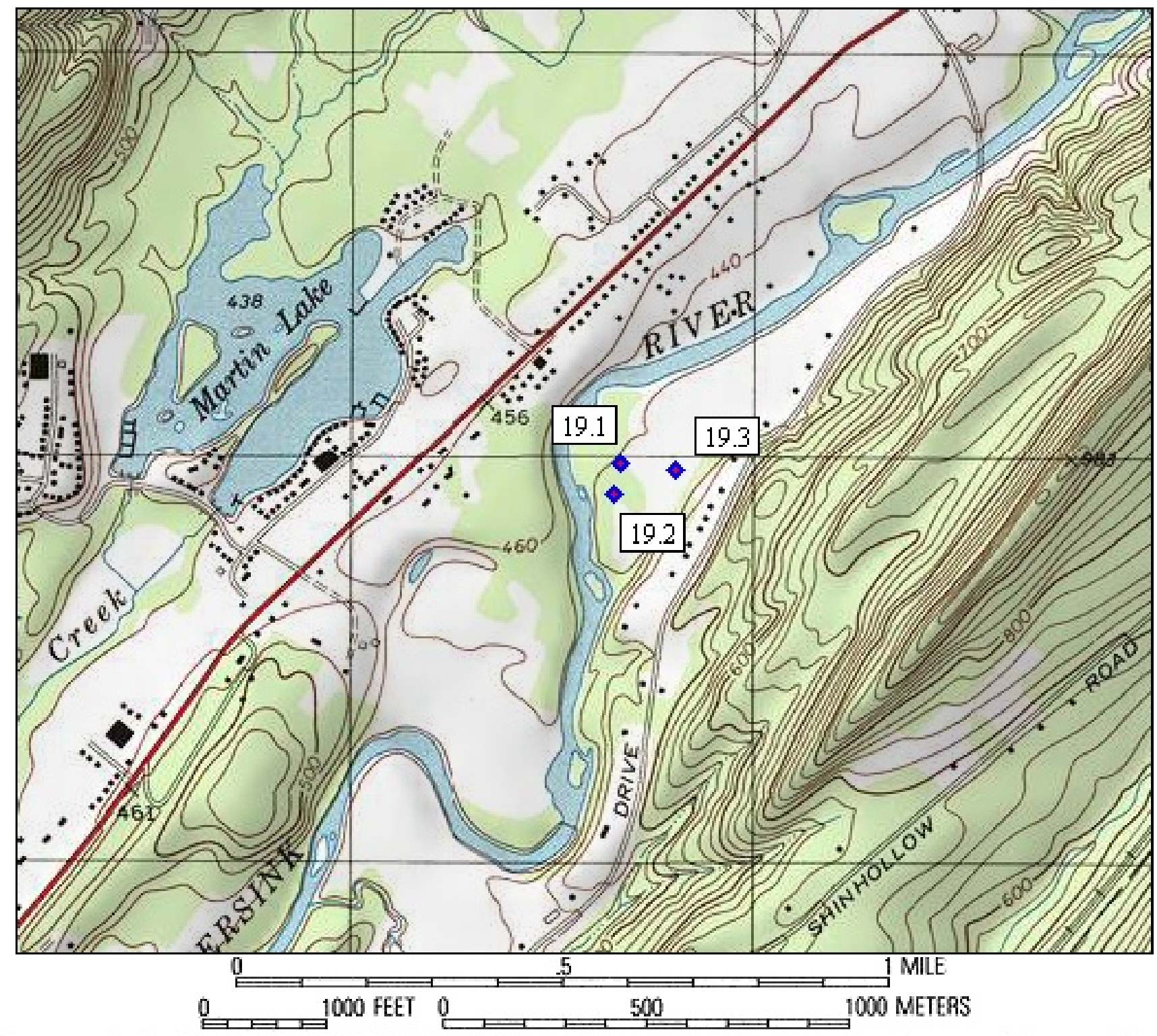

Map created with TOPO!(B) (02003 National Geographic (www.nationalgeographic. com/topo)

Port Jervis North quad map with location of site 19, Neversink River at Riverdale Road at Huguenot, N.Y. 


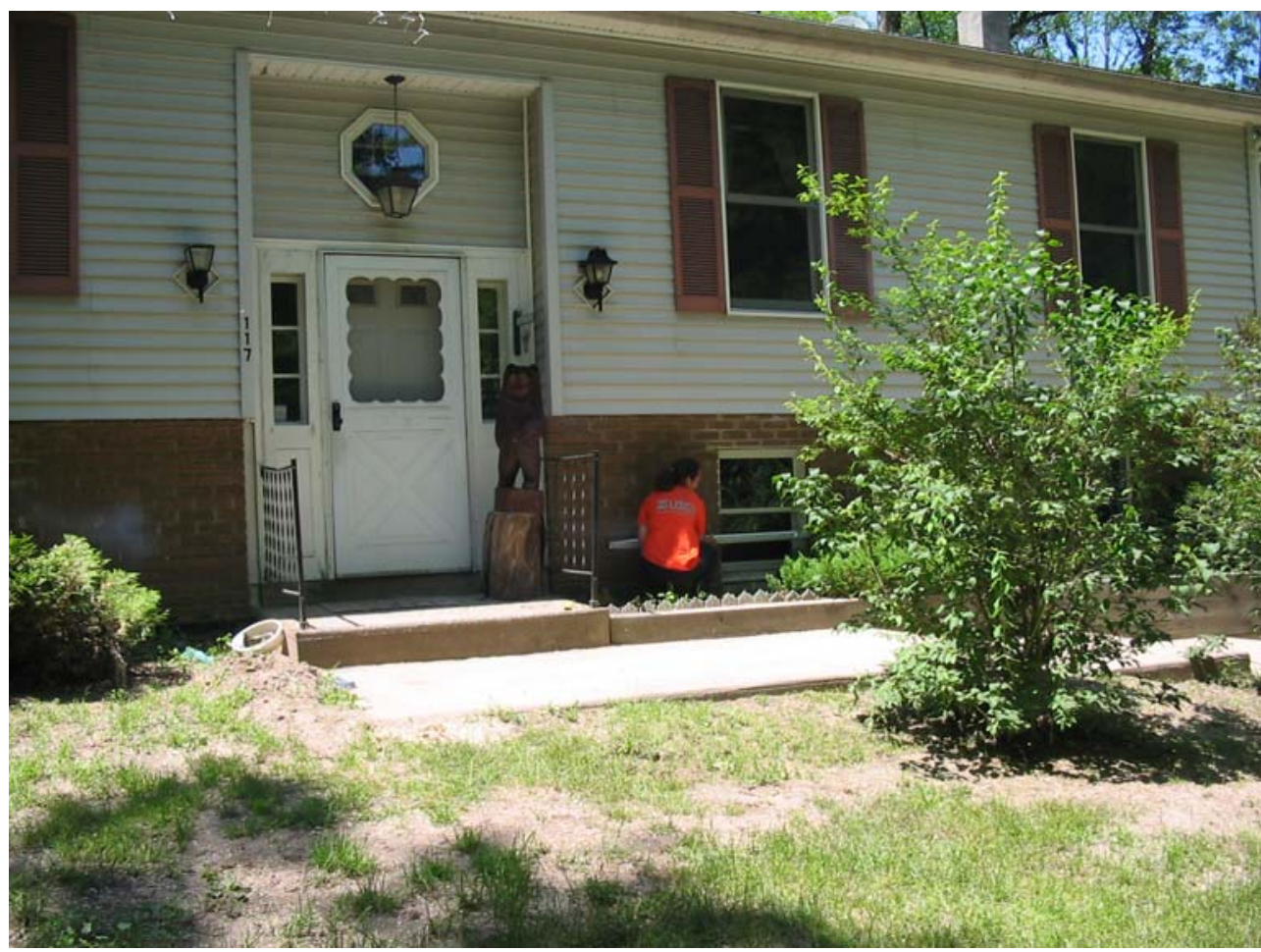

High-water mark 19.1 is an excellent mud line about 2 feet above the ground, on the landward side of house 117 on Riverdale Road, on the left bank, at elevation 441.59 feet above NGVD 29 (lat $41^{\circ} 23^{\prime} 59.5^{\prime \prime}$, long $74^{\circ} 38^{\prime} 40.8^{\prime \prime}$ ).

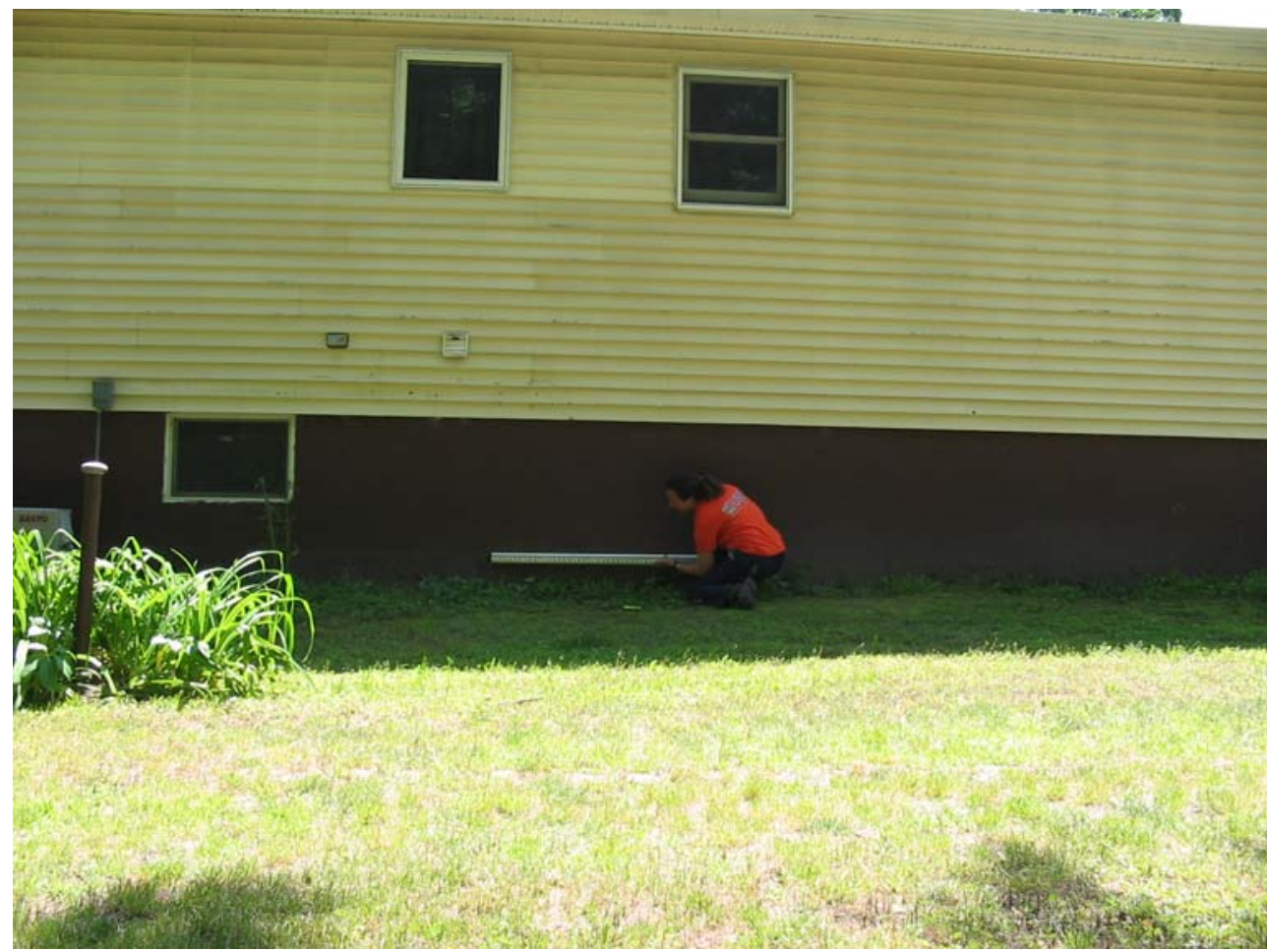

High-water mark 19.2 is an excellent mud line about 1 foot above the ground, on the landward side of house just downstream from house 100 on Riverdale Road, on the left bank, at elevation 441.43 feet above NGVD 29 (lat $41^{\circ} 23^{\prime}$ '56.9”, long 74 38' $41.5 ”)$. 


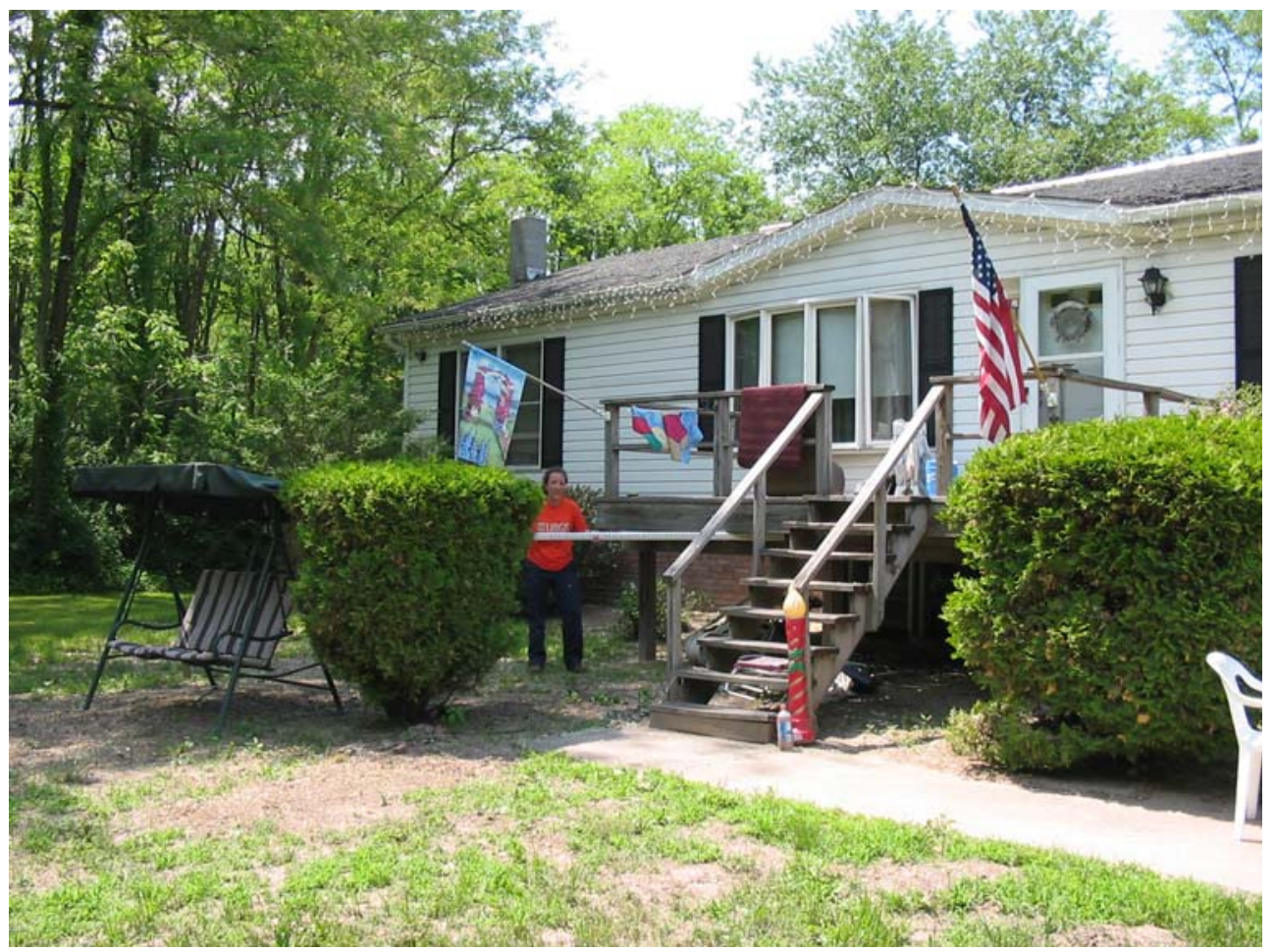

High-water mark 19.3 is an excellent seed line about 4 feet above the ground, on the landward side of house 26 on Riverdale Road, on the left bank, at elevation 441.56 feet above NGVD 29 (lat $41^{\circ} 23^{\prime} 58.9^{\prime \prime}$, long $74^{\circ} 38^{\prime} 35.0^{\prime \prime}$ ). 
Page left intentionally blank 
SITE DESCRIPTION

Site 20: Neversink River at Hamilton Street at Port Jervis, N.Y.

Site Location: Hamilton Street, lat $41^{\circ} 22^{\prime} 34.4^{\prime \prime}$, long $74^{\circ} 40^{\prime} 34.8^{\prime \prime}$, NAD 83

City of Port Jervis, Town of Deerpark, Orange County, N.Y.

Port Jervis North USGS 7.5' Topographic Quadrangle

High-Water Marks: Two high-water marks were surveyed: two seed lines.

Photos and GPS readings were taken at each high-water mark. Field notes are filed at the USGS office in Troy, N.Y.

Marks were surveyed and photos taken by G.D. Firda and A.M Gearwar on June 7, 2005.

High-water-mark elevations were surveyed from a reference mark that is a chiseled $\mathrm{X}$ on the northwest concrete abutment of the Hamilton Street bridge over Gold Creek. This is RM 6 in the Town of Deerpark FEMA flood-insurance study. Elevation is 428.68 feet above NGVD 29. To convert to NAVD 88, subtract 0.57 feet from all elevations at this site.

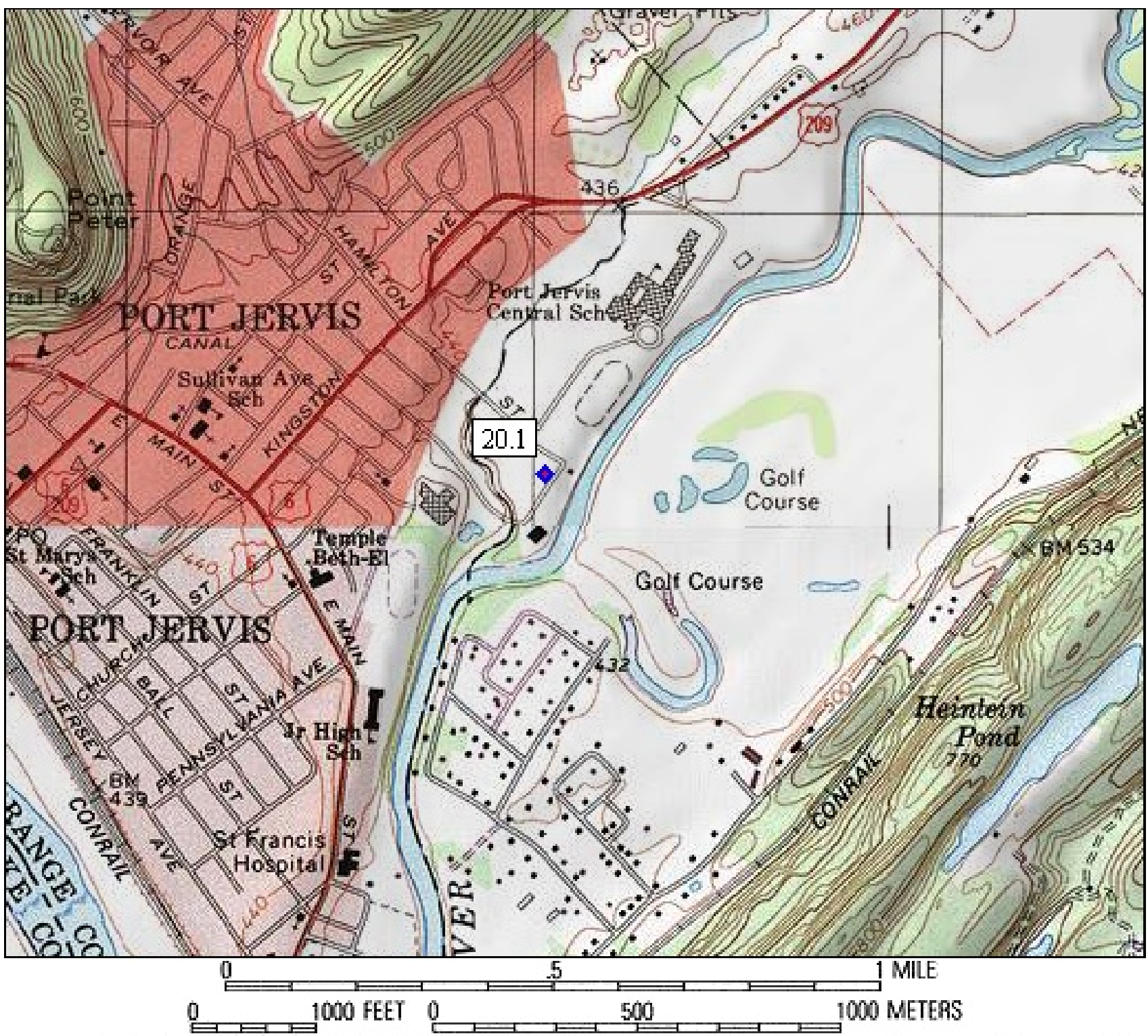

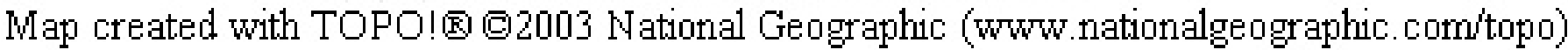

Port Jervis North quad map with location of site 20, Neversink River at Hamilton Street at Port Jervis, N.Y. 


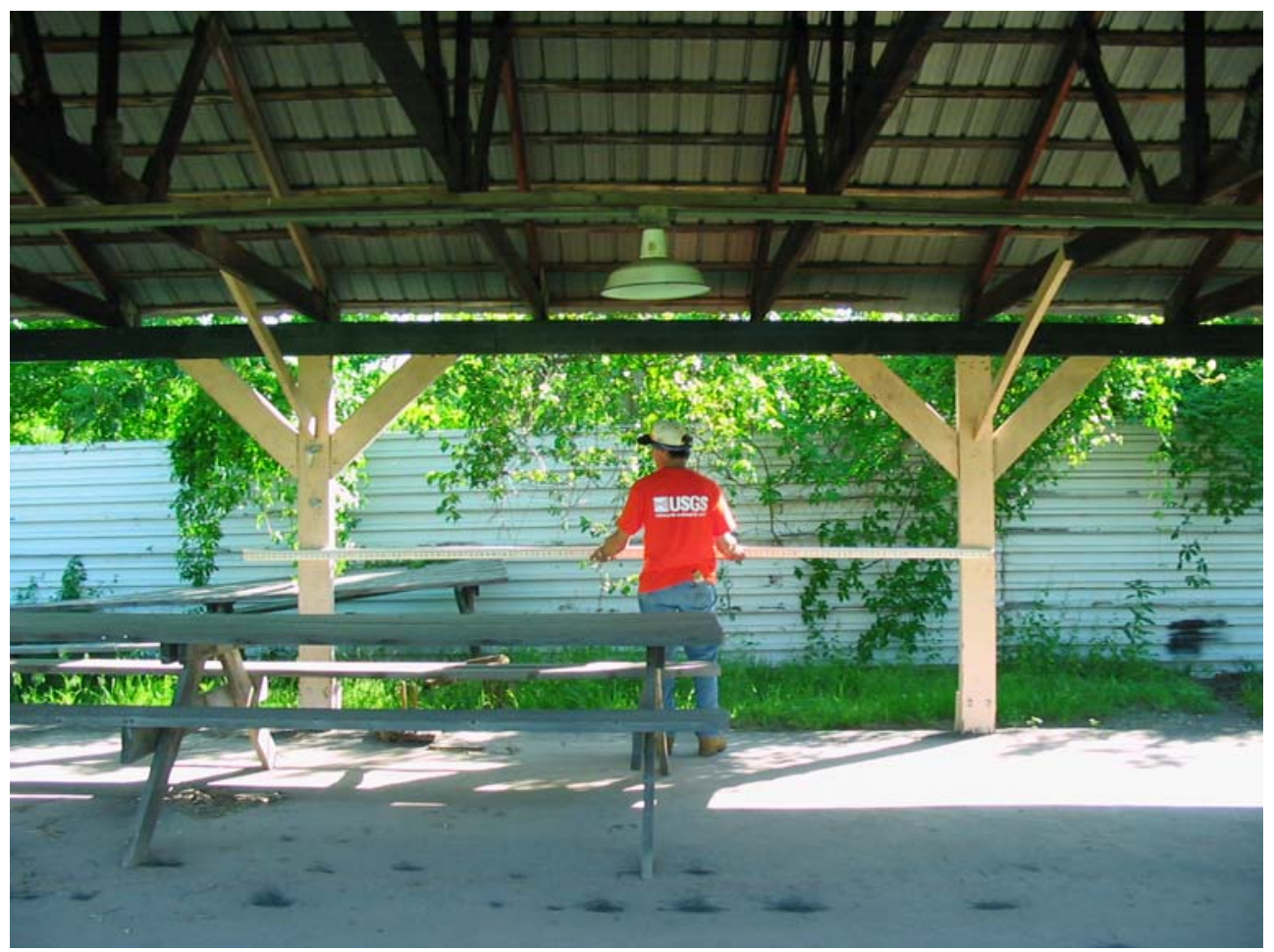

High-water mark 20.1 is an excellent seed line about 4 feet above the ground, on the Chief Donald E. DeVore Training Center pavilion support posts, on the right bank, at elevation 436.69 feet above NGVD 29 (lat $41^{\circ} 22^{\prime} 34.4^{\prime \prime}$, long $74^{\circ} 40^{\prime} 34.8^{\prime \prime}$ ). 
SITE DESCRIPTION

Site 21: Neversink River at Rivers Edge Road at Port Jervis, N.Y.

Site Location: Rivers Edge Road, lat $41^{\circ} 22^{\prime} 10.8^{\prime \prime}$, long $74^{\circ} 40^{\prime} 48.2^{\prime \prime}$, NAD 83

City of Port Jervis, Town of Deerpark, Orange County, N.Y.

Port Jervis South USGS 7.5' Topographic Quadrangle

High-Water Marks: Five high-water marks were surveyed: four mud lines and one seed line.

Photos and GPS readings were taken at each high-water mark. Field notes are filed at the USGS office in Troy, N.Y.

Marks were surveyed and photos taken by G.D. Firda and A.M. Gearwar on June 7, 2005.

High-water-mark elevations were surveyed from a benchmark that is an NGS standard disk stamped 431.623 NEVERSINK

1933 on East Main Street bridge over the Neversink River at Port Jervis on the south concrete backwall, NGS PID LY0728.

Elevation is 431.62 feet above NGVD 29. To convert to NAVD 88, subtract 0.57 feet from all elevations at this site.

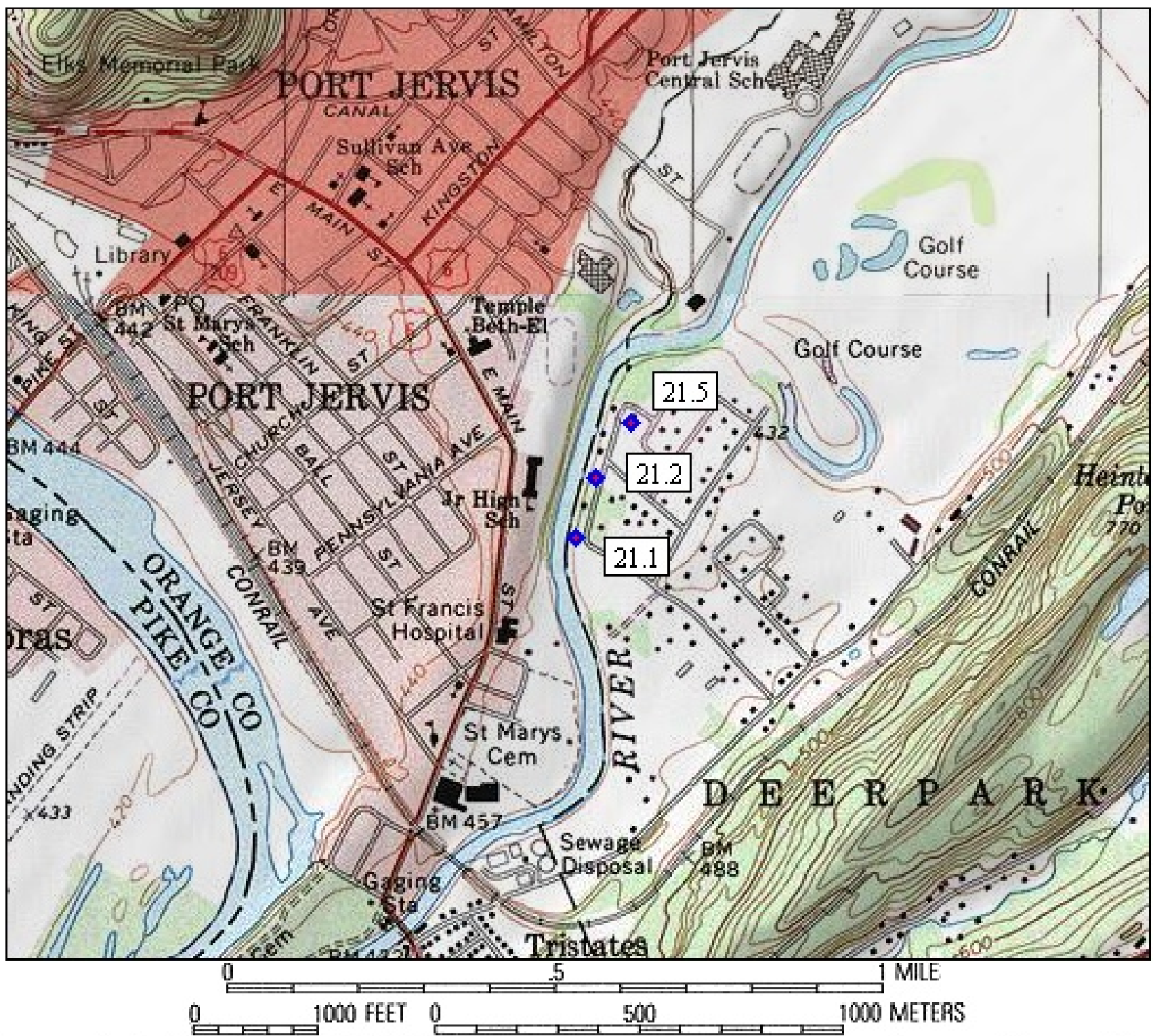

Map created with TOPO!(B) (C)03 National Geographic (www nationalgeographic.com/topo)

Port Jervis South quad map with location of site 21, Neversink River at Rivers Edge Road at Port Jervis, N.Y. 


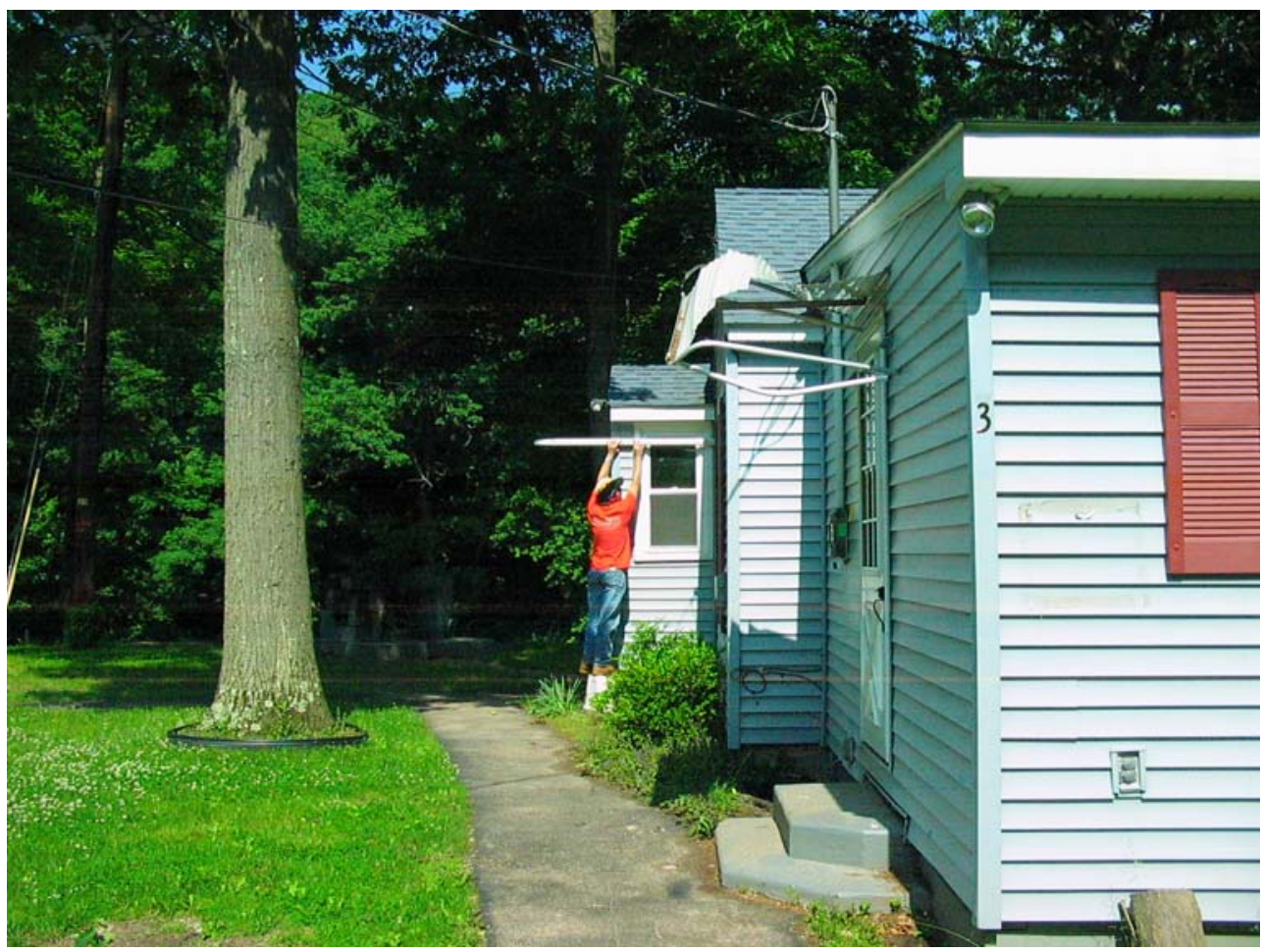

High-water mark 21.1 is an excellent mud line about 9 feet above the ground, on the landward side of house 3 on Rivers Edge Road, on the left bank, at elevation 435.21 feet above NGVD 29 (lat $41^{\circ} 22^{\prime} 10.8^{\prime \prime}$, long $74^{\circ} 40^{\prime} 48.2^{\prime \prime}$ ).

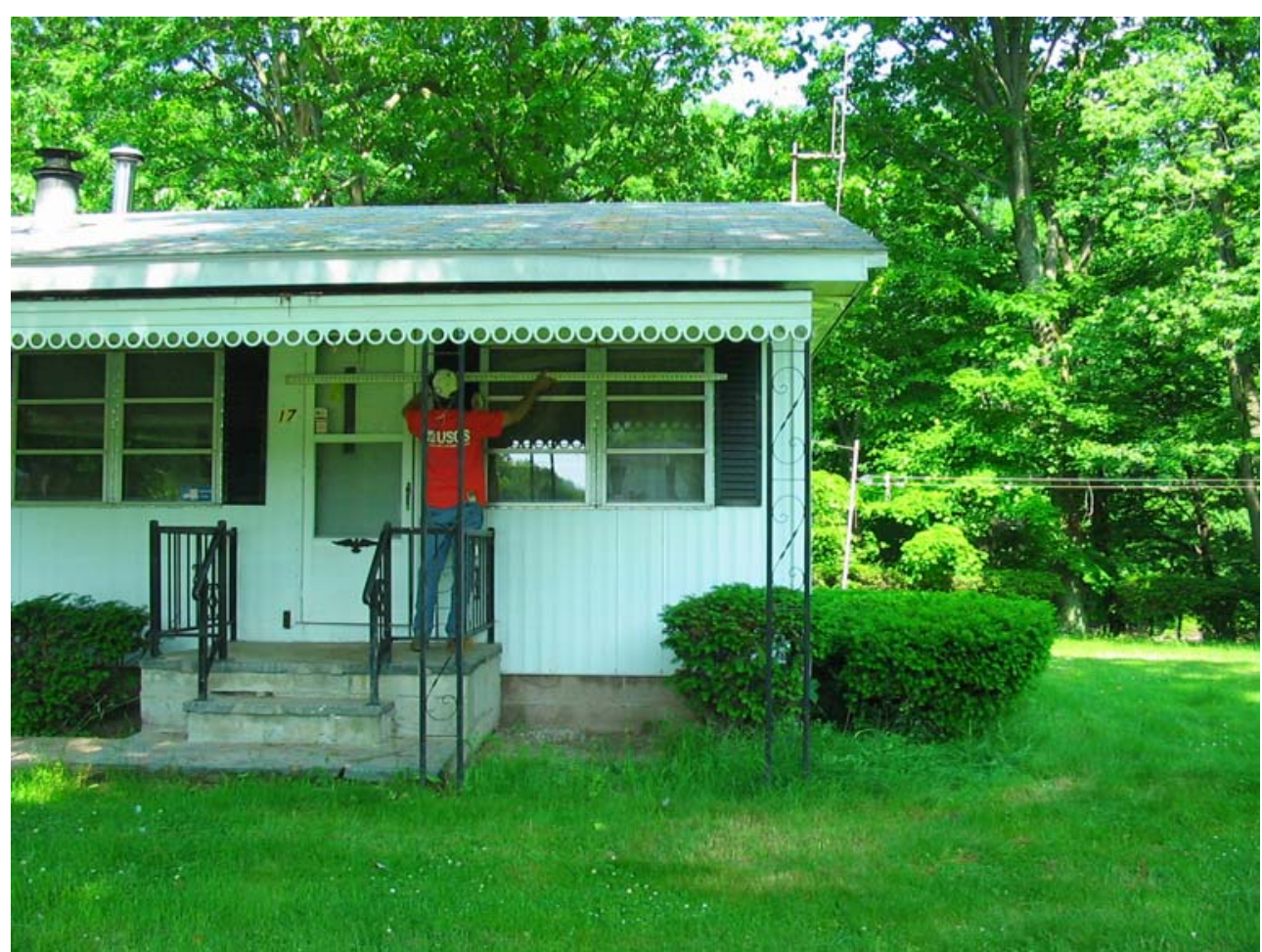

High-water mark 21.2 is an excellent mud line about 8 feet above the ground, on the landward side of house 17 on Rivers Edge Road, on the left bank, at elevation 435.37 feet above NGVD 29 (lat $41^{\circ} 22^{\prime} 15.6^{\prime \prime}$, long $74^{\circ} 40^{\prime} 46.3^{\prime \prime}$ ). 


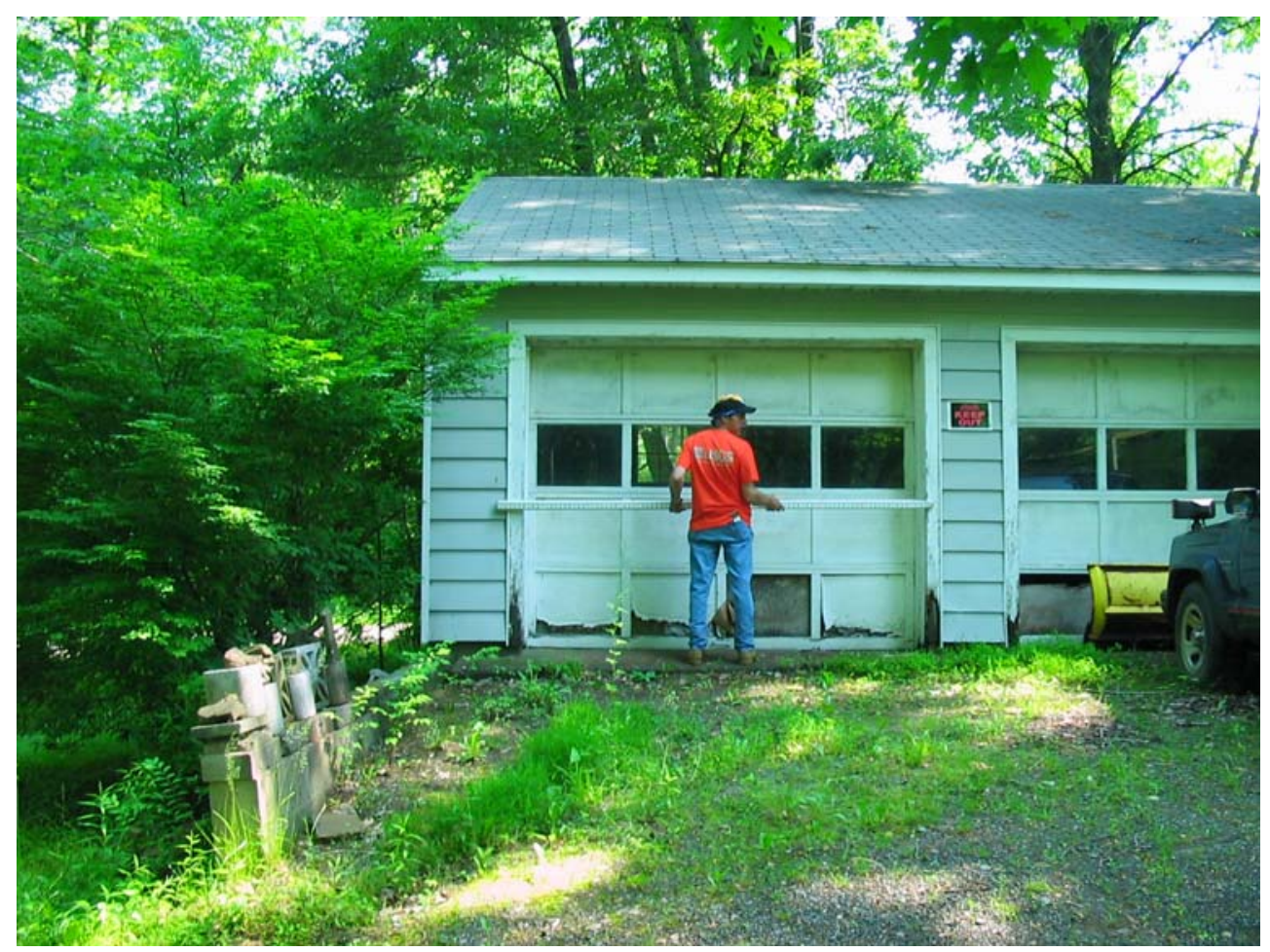

High-water mark 21.5 is an excellent seed line about 4 feet above the ground, on the downstream side of a detached garage upstream from house 30 on Rivers Edge Road, on the left bank, at elevation 435.76 feet above NGVD 29 (lat $41^{\circ} 22^{\prime} 20.0^{\prime \prime}$, long $\left.74^{\circ} 40^{\prime} 42.4^{\prime \prime}\right)$. 
Page left intentionally blank 
SITE DESCRIPTION

Site 22: Neversink River at Christopher Street at Port Jervis, N.Y.

Site Location: Christopher Street, lat $41^{\circ} 21^{\prime}$ 54.4”, long $74^{\circ} 40^{\prime} 44.5^{\prime \prime}$, NAD 83

City of Port Jervis, Town of Deerpark, Orange County, N.Y.

Port Jervis South USGS 7.5' Topographic Quadrangle

High-Water Marks: Three high-water marks were surveyed: three debris lines.

Photos and GPS readings were taken at each high-water mark. Field notes are filed at the USGS office in Troy, N.Y.

Marks were surveyed and photos taken by G.D. Firda and A.M Gearwar on June 7, 2005.

High-water-mark elevations were surveyed from a benchmark that is an NGS standard disk stamped 431.623 NEVERSINK

1933 on East Main Street bridge over the Neversink River at Port Jervis on the south concrete backwall, NGS PID LY0728.

Elevation is 431.62 feet above NGVD 29. To convert to NAVD 88, subtract 0.57 feet from all elevations at this site.

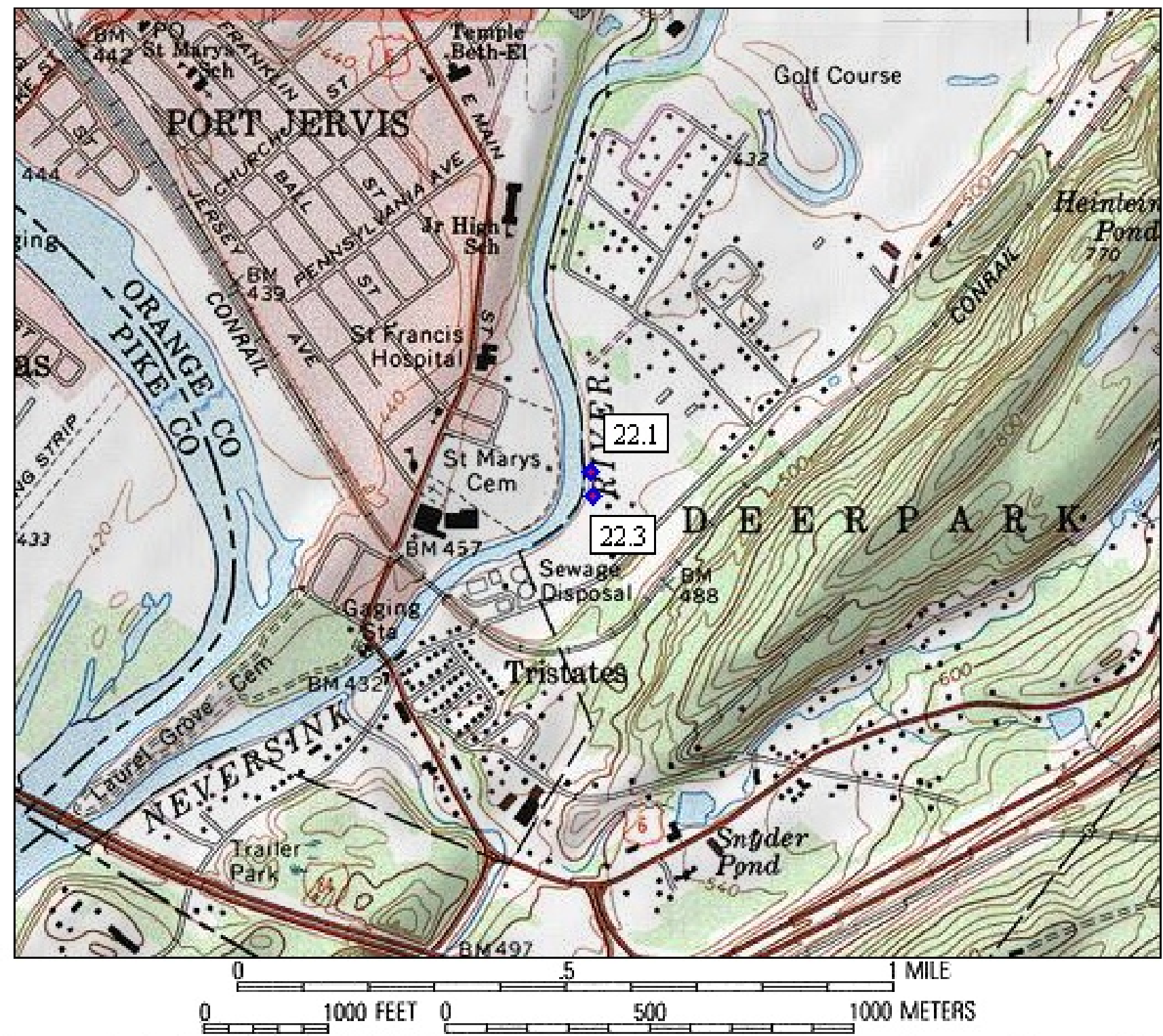

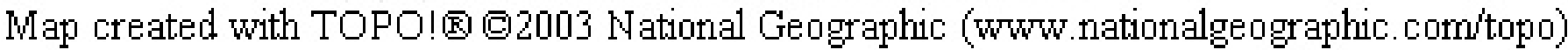

Port Jervis South quad map with location of site 22, Neversink River at Christopher Street at Port Jervis, N.Y. 


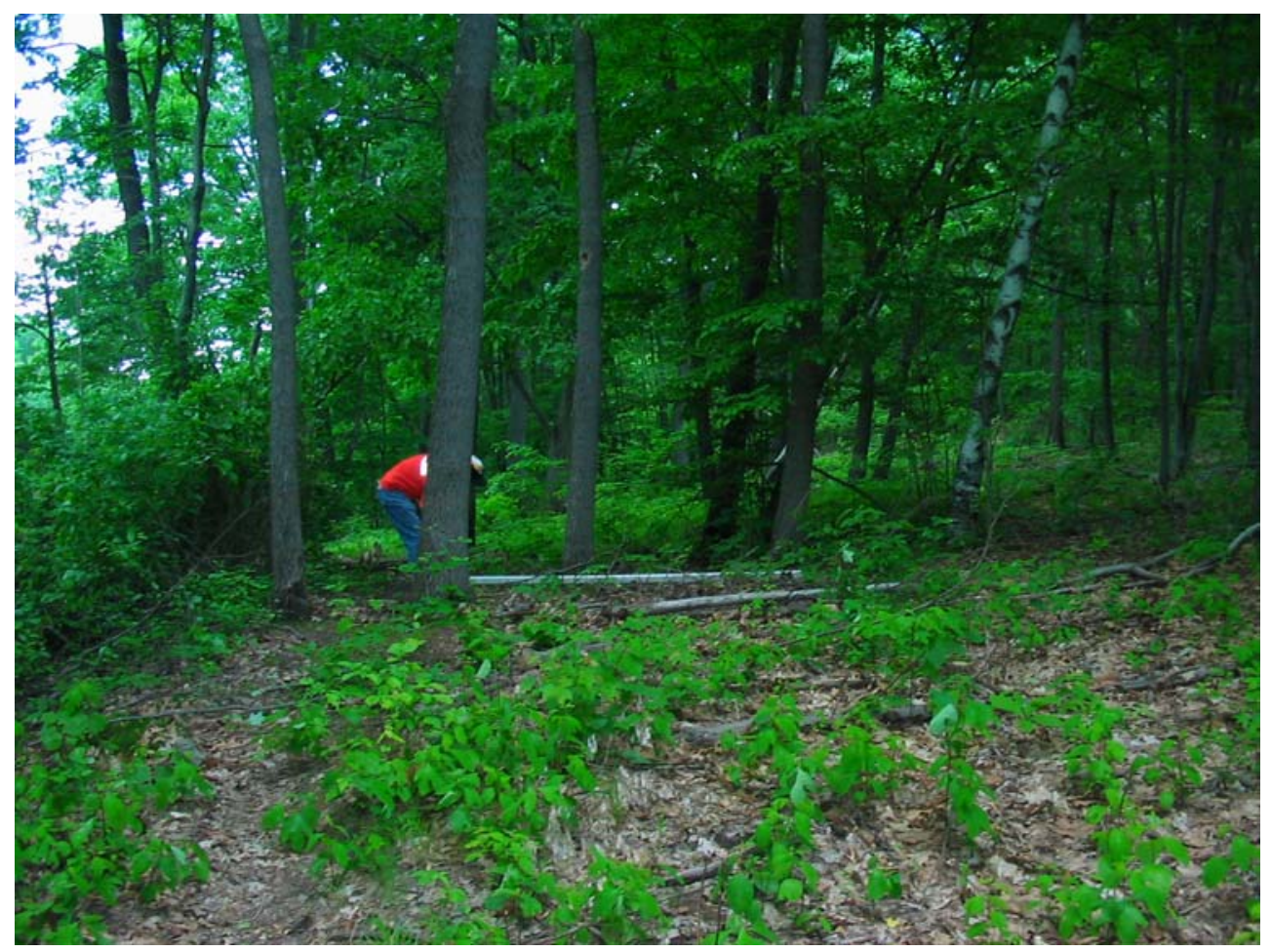

High-water mark 22.1 is a fair debris line on the ground, on the left bank, 200 feet upstream from house 11 on Christopher Street, at elevation 434.05 feet above NGVD 29 (lat $41^{\circ} 21^{\prime} 54.4^{\prime \prime}$, long $74^{\circ} 40^{\prime} 44.5^{\prime \prime}$ ).

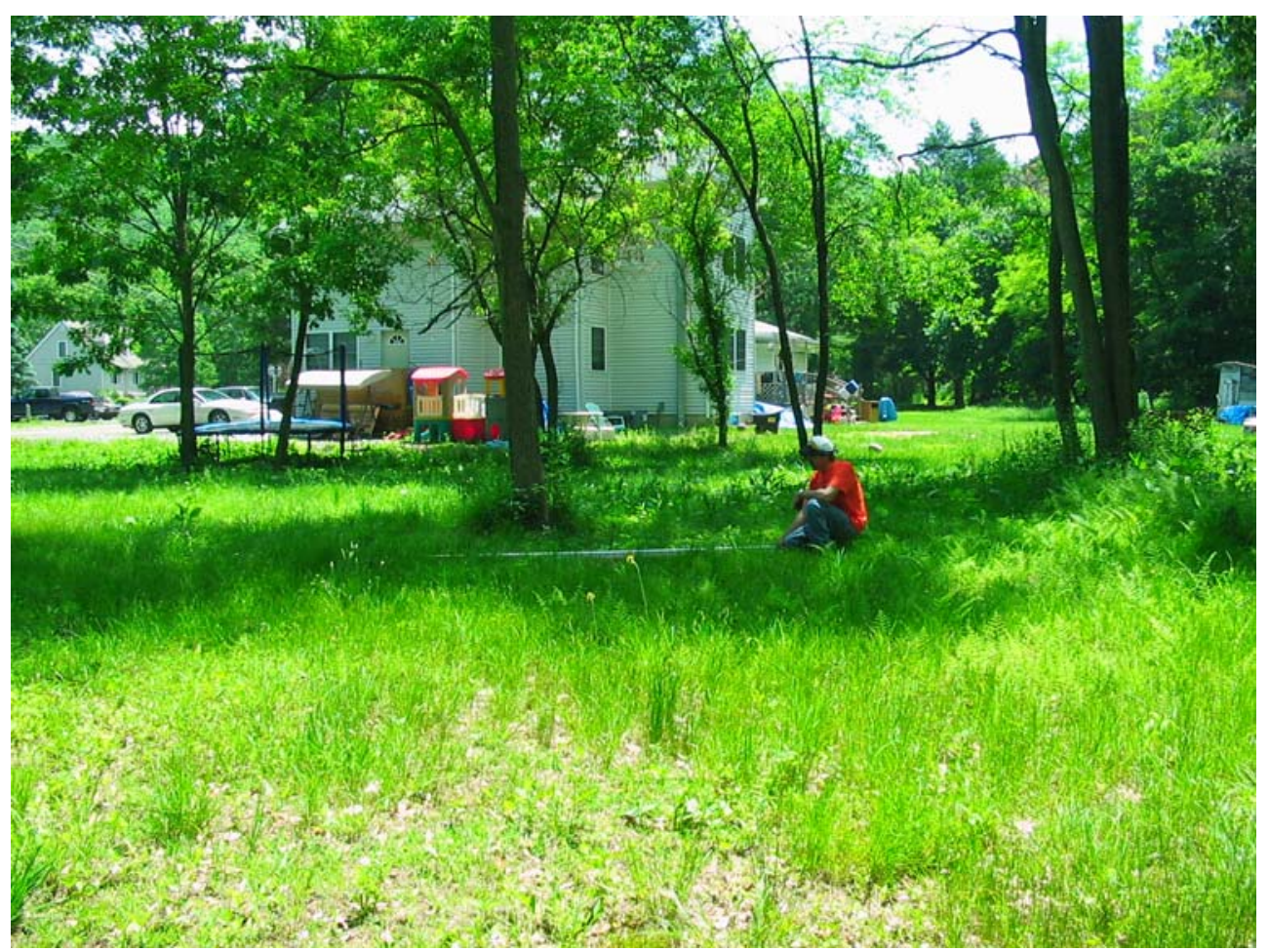

High-water mark 22.3 is a fair debris line on the ground, on the left bank, 60 feet streamward from house 11 on Christopher Street, at elevation 433.96 feet above NGVD 29 (lat $41^{\circ} 21^{\prime} 52.3^{\prime \prime}$, long $74^{\circ} 40^{\prime} 44.3^{\prime \prime}$ ). 


\begin{tabular}{|l|}
\hline \multicolumn{1}{|c|}{ SITE DESCRIPTION } \\
\hline Site 23: Neversink River at Norfolk Southern Railroad at Port Jervis, N.Y. \\
\hline Site Location: Bridge on Norfolk Southern Railroad, lat 41 ${ }^{\circ} 21^{\prime} 45.6^{\prime}$, long $74^{\circ} 41^{\prime}$ '01.2”, NAD 83 \\
\hline City of Port Jervis, Town of Deerpark, Orange County, N.Y. \\
\hline Port Jervis South USGS 7.5' Topographic Quadrangle \\
\hline High-Water Marks: Five high-water marks were surveyed: four debris lines and one mud line. \\
\hline Photos and GPS readings were taken at each high-water mark. Field notes are filed at the USGS office in Troy, N.Y. \\
\hline Marks were surveyed and photos taken by G.D. Firda and A.M. Gearwar on June 7, 2005. \\
\hline $\begin{array}{l}\text { High-water-mark elevations were surveyed from a benchmark that is an NGS standard disk stamped 431.623 NEVERSINK } \\
\text { 1933 on East Main Street bridge over the Neversink River at Port Jervis on the south concrete backwall, NGS PID LY0728. } \\
\text { Elevation is 431.62 feet above NGVD 29. To convert to NAVD 88, subtract 0.57 feet from all elevations at this site. }\end{array}$ \\
\hline
\end{tabular}

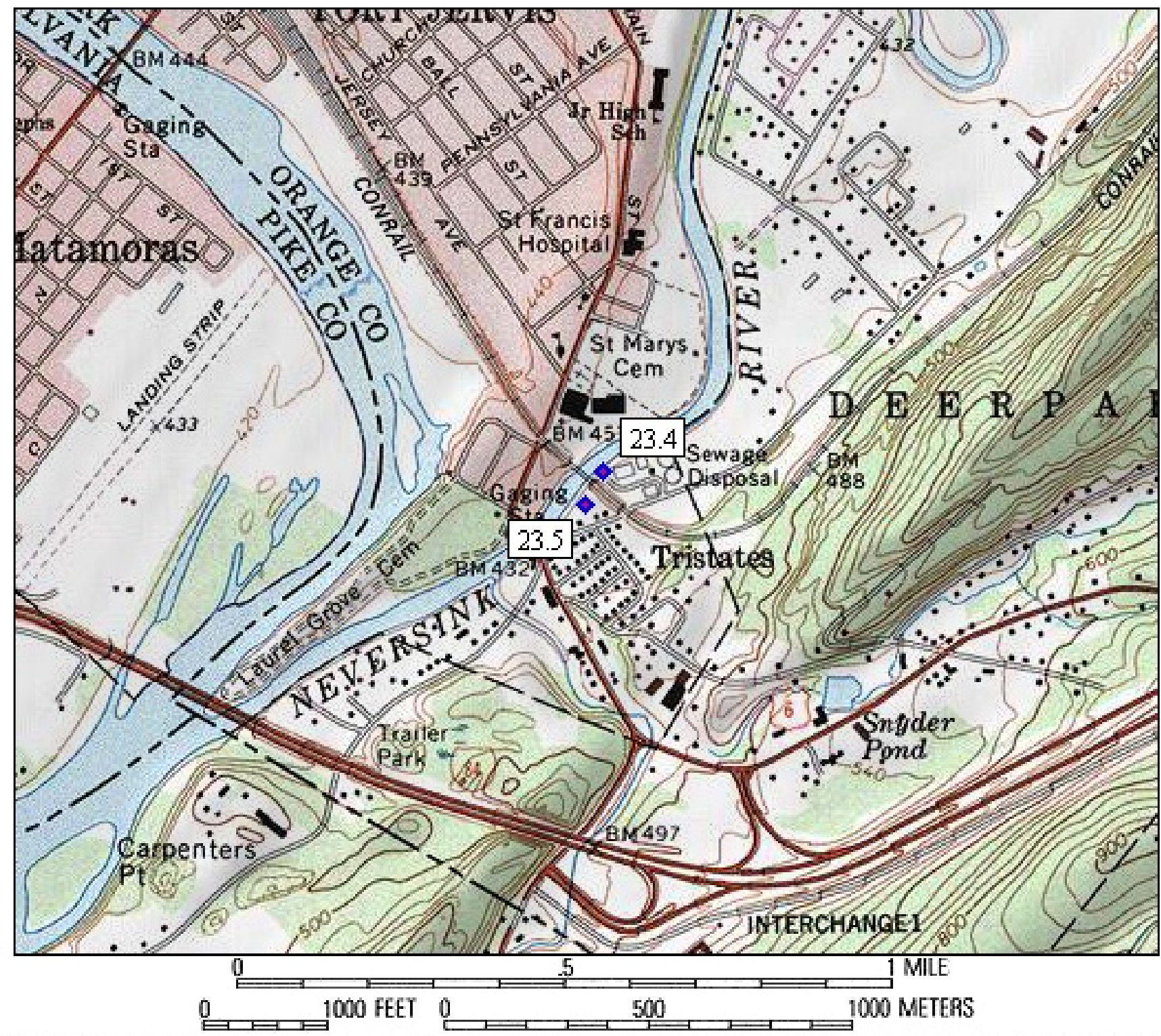

Map created with TOPO!(B) (1003 National Geographic (www.nationalgeographic. com/topo)

Port Jervis South quad map with location of site 23, Neversink River at Norfolk Southern Railroad at Port Jervis, N.Y. 


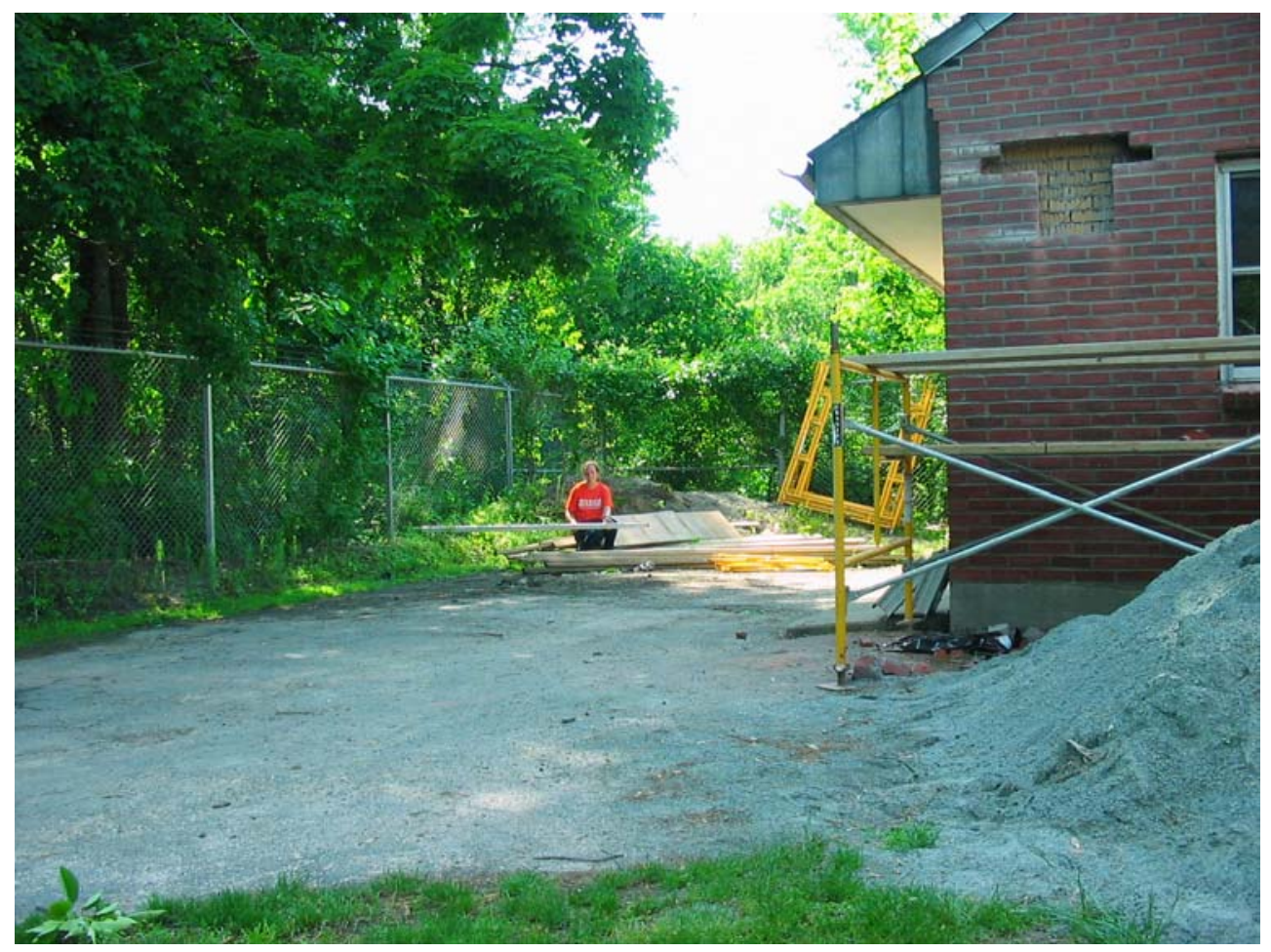

High-water mark 23.4 is a good debris line about 2 feet above the ground, on the Port Jervis Wastewater Treatment Plant downstream security fence, on the left bank, 80 feet upstream from the Norfolk Southern Railroad bridge, at elevation 433.11 feet above NGVD 29 (lat $41^{\circ} 21^{\prime} 45.1^{\prime \prime}$, long $74^{\circ} 40^{\prime} 58.8^{\prime \prime}$ ).

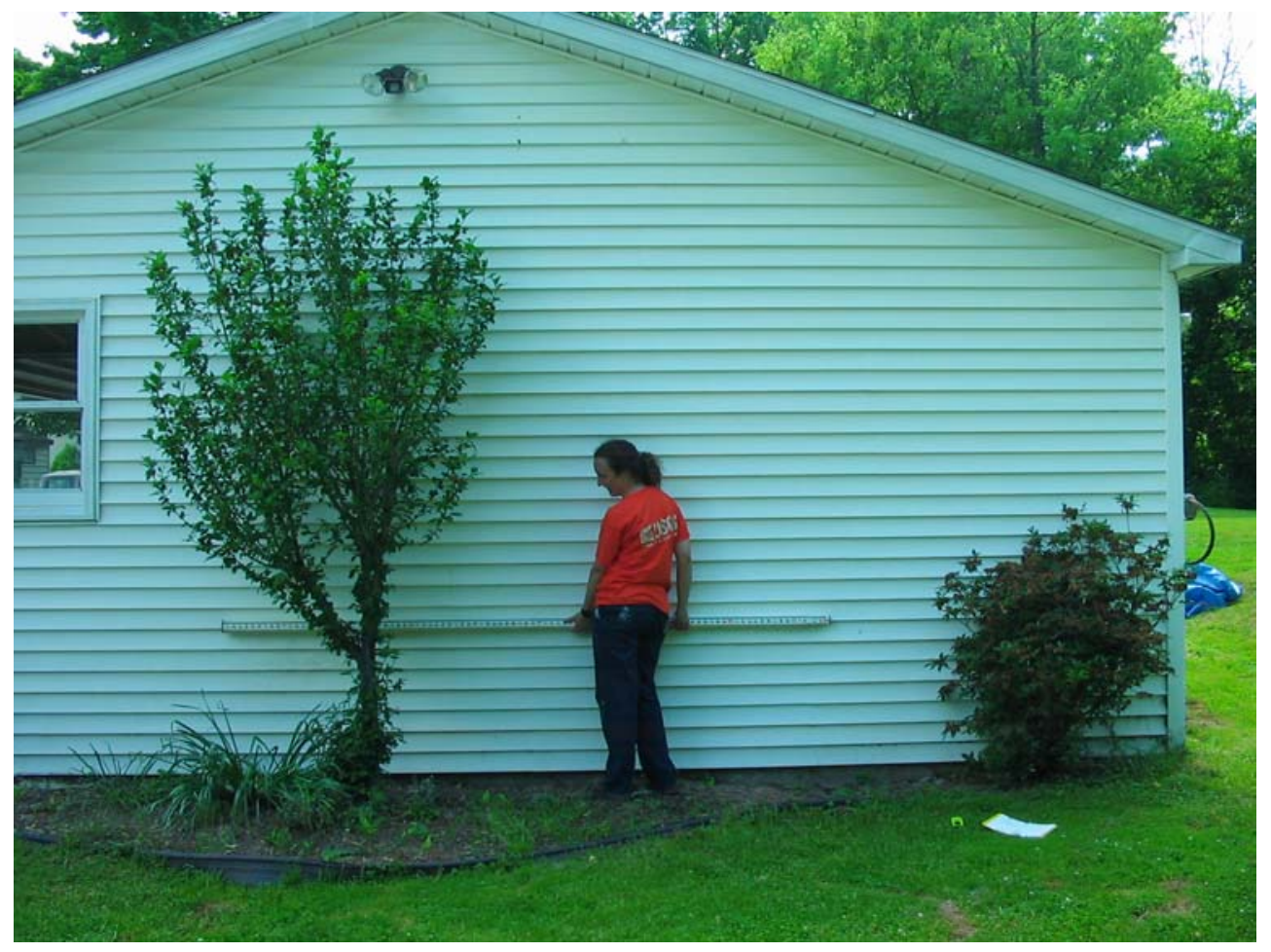

High-water mark 23.5 is an excellent mud line about 3 feet above the ground, on the upstream side of a detached garage streamward from house 26 on North Maple Avenue, on the left bank, 190 feet downstream from the Norfolk Southern Railroad bridge, at elevation 432.68 feet above NGVD 29 (lat $41^{\circ} 21^{\prime} 42.5^{\prime \prime}$, long $74^{\circ} 41^{\prime} 00.6^{\prime \prime}$ ). 
SITE DESCRIPTION

Site 24: Neversink River at U.S. Route 6 (East Main Street) at Port Jervis, N.Y.

Site Location: Bridge on U.S. Route 6, lat $41^{\circ} 21^{\prime} 40.2^{\prime \prime}$, long $74^{\circ} 41^{\prime}$ 06.6”, NAD 83

City of Port Jervis, Town of Deerpark, Orange County, N.Y.

Port Jervis South USGS 7.5' Topographic Quadrangle

High-Water Marks: Four high-water marks were surveyed: two debris lines and two mud lines.

Photos and GPS readings were taken at each high-water mark. Field notes are filed at the USGS office in Troy, N.Y.

Marks were surveyed and photos taken by G.D. Firda, C.L. Gazoorian, and R. Lumia on April 19, 2005, and G.D. Firda and

A.M. Gearwar on June 6, 2005.

High-water-mark elevations were surveyed from a benchmark that is an NGS standard disk stamped 431.623 NEVERSINK 1933 on East Main Street bridge over the Neversink River at Port Jervis on the south concrete backwall, NGS PID LY0728.

Elevation is 431.62 feet above NGVD 29. To convert to NAVD 88, subtract 0.57 feet from all elevations at this site.

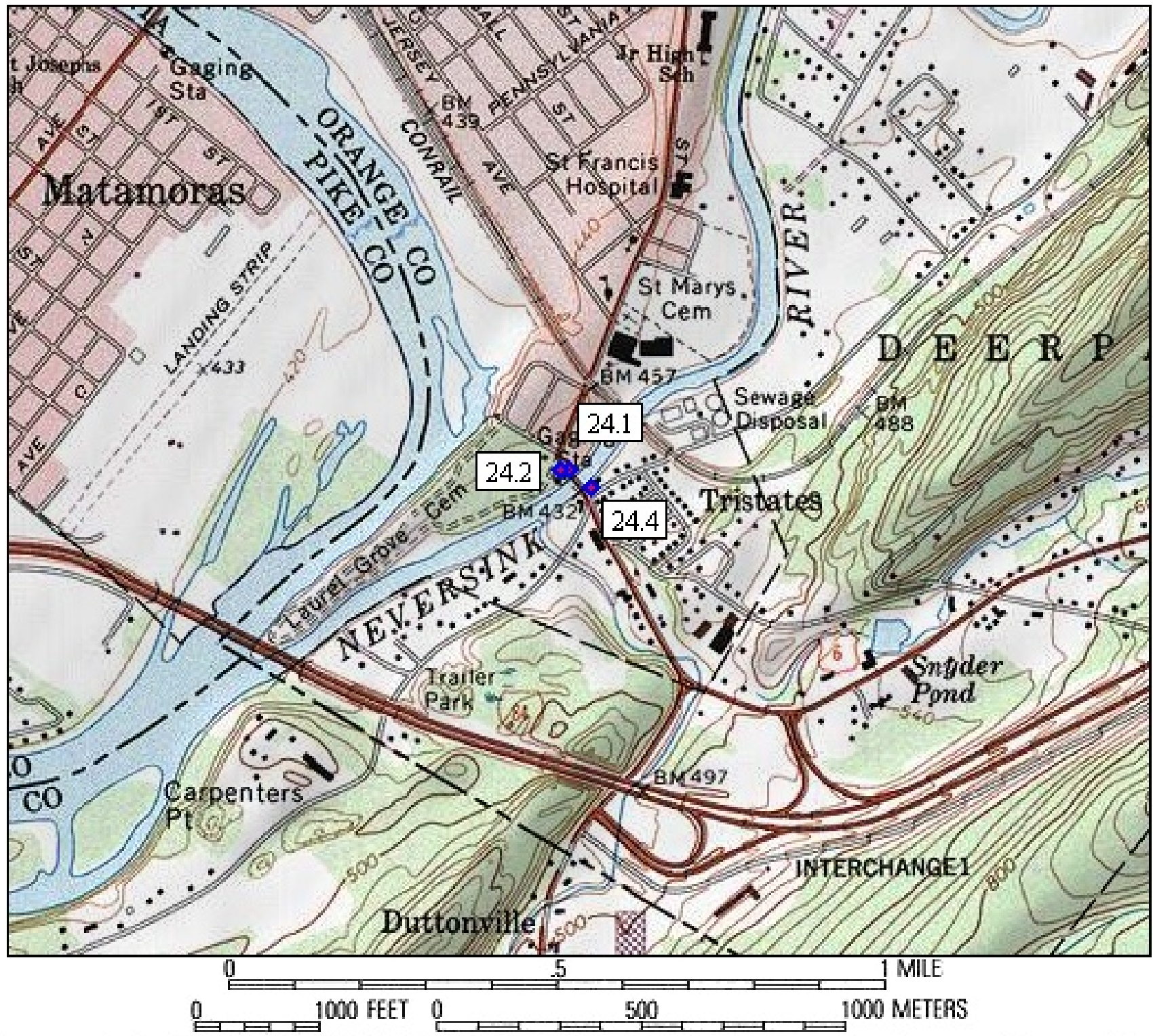

Map created with TOPO!(G) (G003 National Geographic (www.nationalgeographic.com/topo)

Port Jervis South quad map with location of site 24, Neversink River at U.S. Route 6 (East Main Street) at Port Jervis, N.Y. 


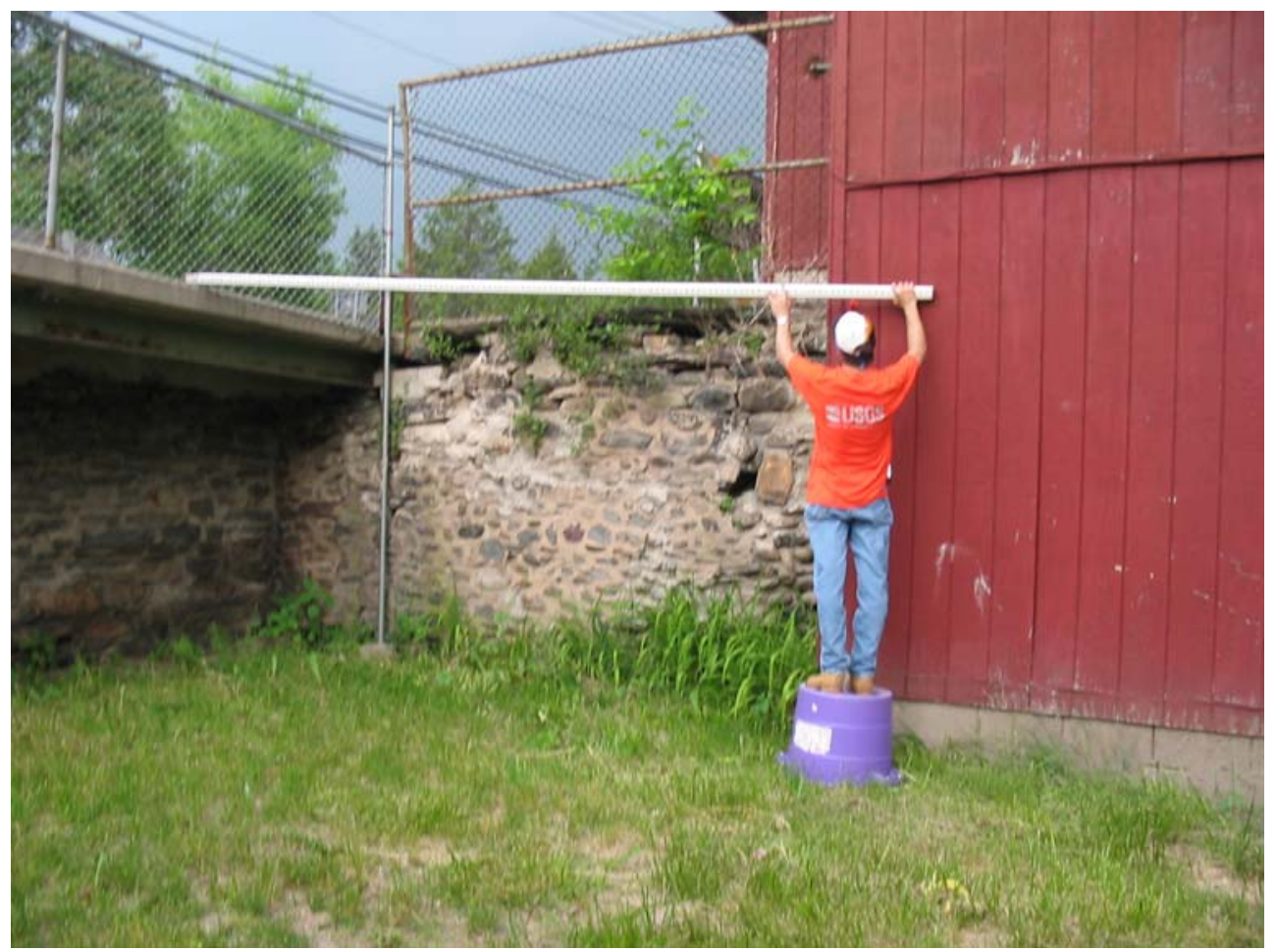

High-water mark 24.1 is an excellent mud line about 8 feet above the ground, on the streamward side of house 246 on East Main Street, on the right bank, 10 feet upstream from the East Main Street bridge, at elevation 432.62 feet above NGVD 29 (lat $41^{\circ} 21^{\prime} 40.8^{\prime \prime}$, long $\left.74^{\circ} 41^{\prime} 07.4^{\prime \prime}\right)$.

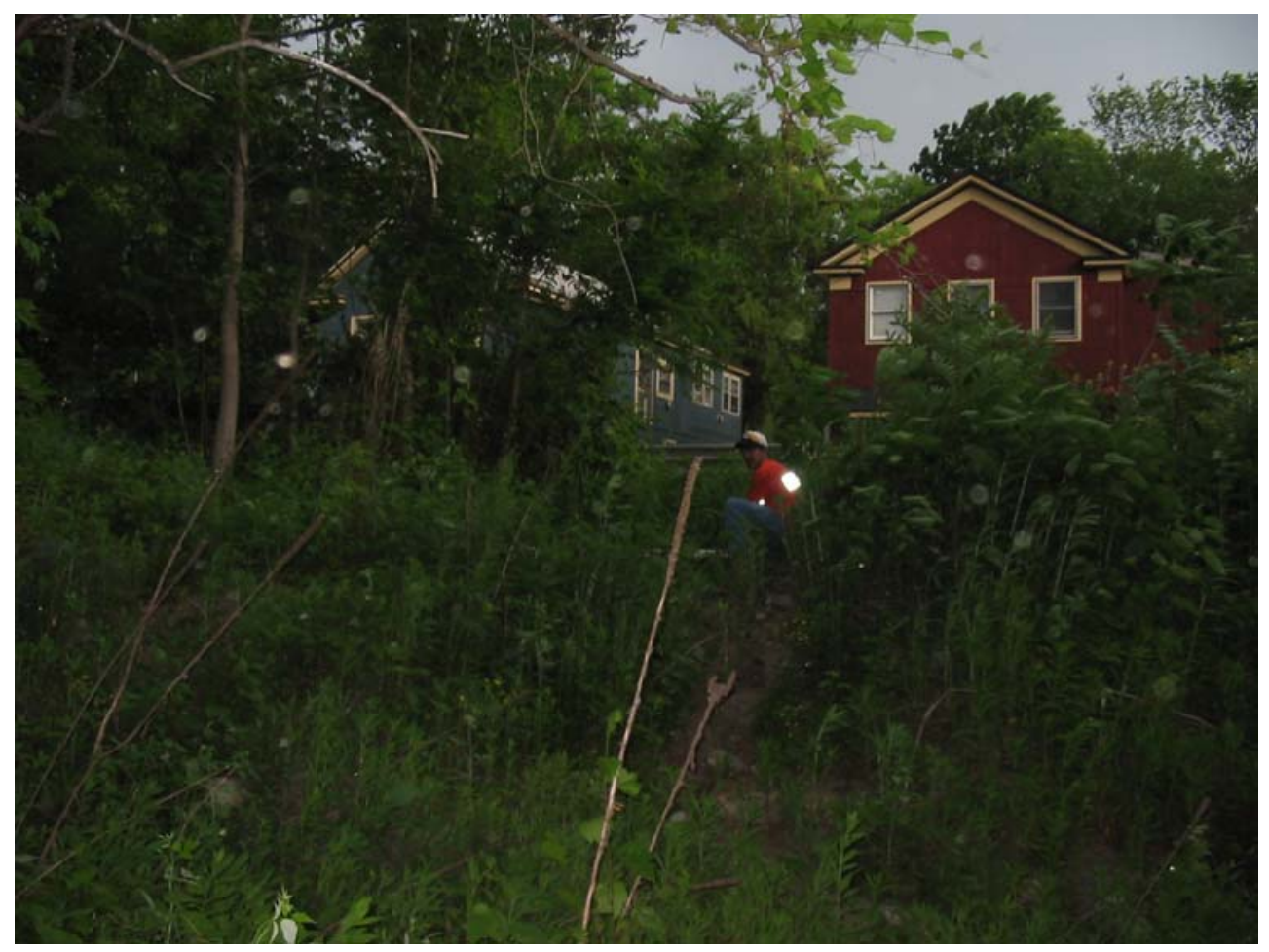

High-water mark 24.2 is a good debris line on the ground, on the right bank, 25 feet downstream from the East Main Street bridge, at elevation 431.73 feet above NGVD 29 (lat $41^{\circ} 21^{\prime}$ '40.7”, long $74^{\circ} 41^{\prime} 08.3^{\prime \prime}$ ). 


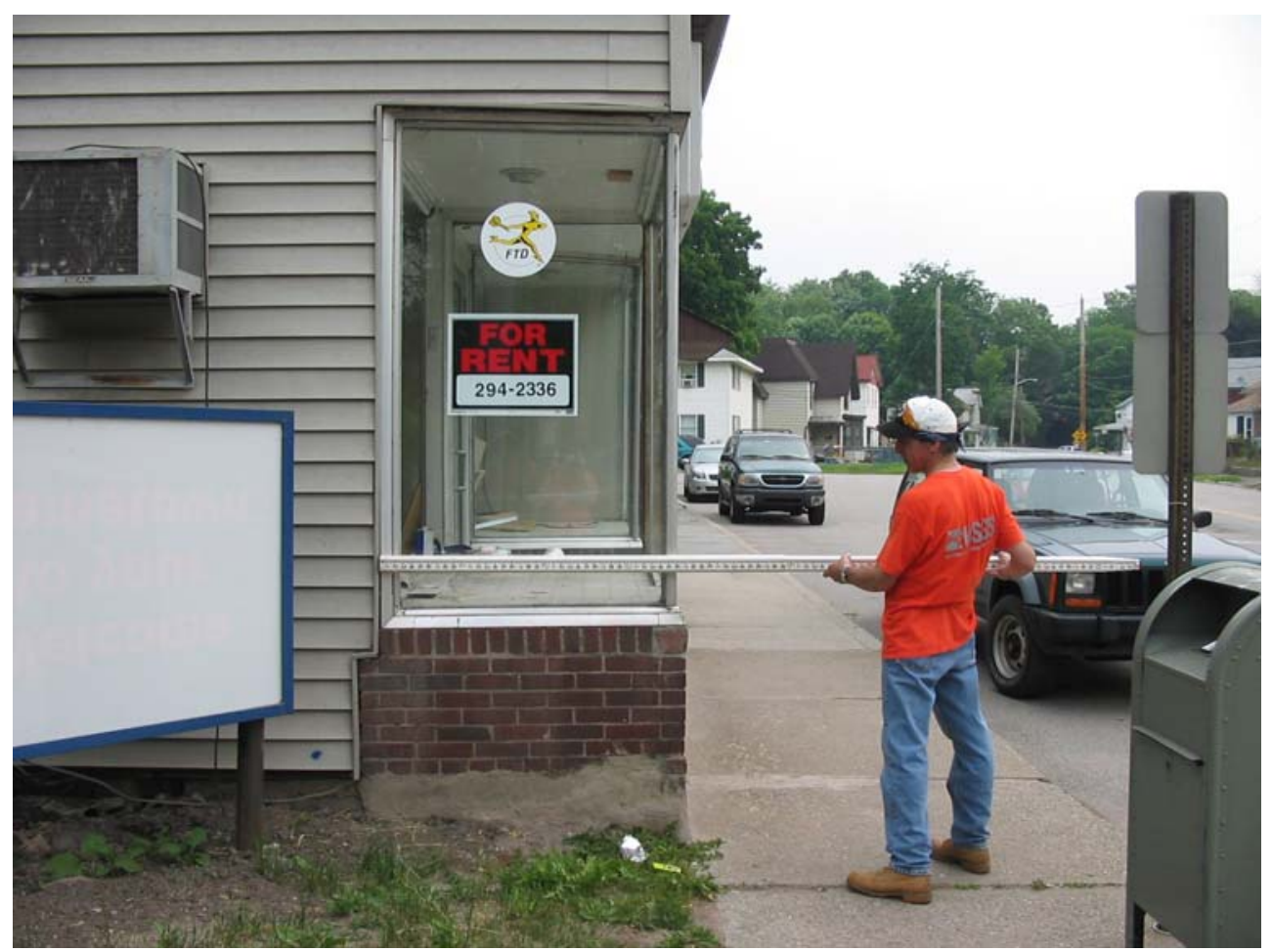

High-water mark 24.4 is a good mud line about 4 feet above the ground, on the downstream side of building 4 on North Maple Avenue, on the left bank, 10 feet upstream from the East Main Street bridge, at elevation 431.97 feet above NGVD 29 (lat $41^{\circ}$ 21'39.4", long 74 41'05.2'). 
Page left intentionally blank 
SITE DESCRIPTION

Site 25: Confluence of Delaware and Neversink Rivers at Interstate Route 84 at Port Jervis, N.Y.

Site Location: Bridges on Interstate Route 84, lat $41^{\circ} 21^{\prime} 28.2^{\prime \prime}$, long $74^{\circ} 41^{\prime} 43.8^{\prime \prime}$, NAD 83

City of Port Jervis, Town of Deerpark, Orange County, N.Y.

Port Jervis South USGS 7.5' Topographic Quadrangle

High-Water Marks: Six high-water marks were surveyed: three seed lines and three debris lines.

Photos and GPS readings were taken at each high-water mark. Field notes are filed at the USGS office in Troy, N.Y.

Marks were surveyed and photos taken by G.D. Firda, C.L. Gazoorian, and R. Lumia on April 19, 2005, and G.D. Firda and

A.M. Gearwar on June 6, 2005.

High-water-mark elevations were surveyed from a benchmark that is an NGS standard disk stamped 431.623 NEVERSINK 1933 on East Main Street bridge over the Neversink River at Port Jervis on the south concrete backwall, NGS PID LY0728.

Elevation is 431.62 feet above NGVD 29. To convert to NAVD 88, subtract 0.57 feet from all elevations at this site.

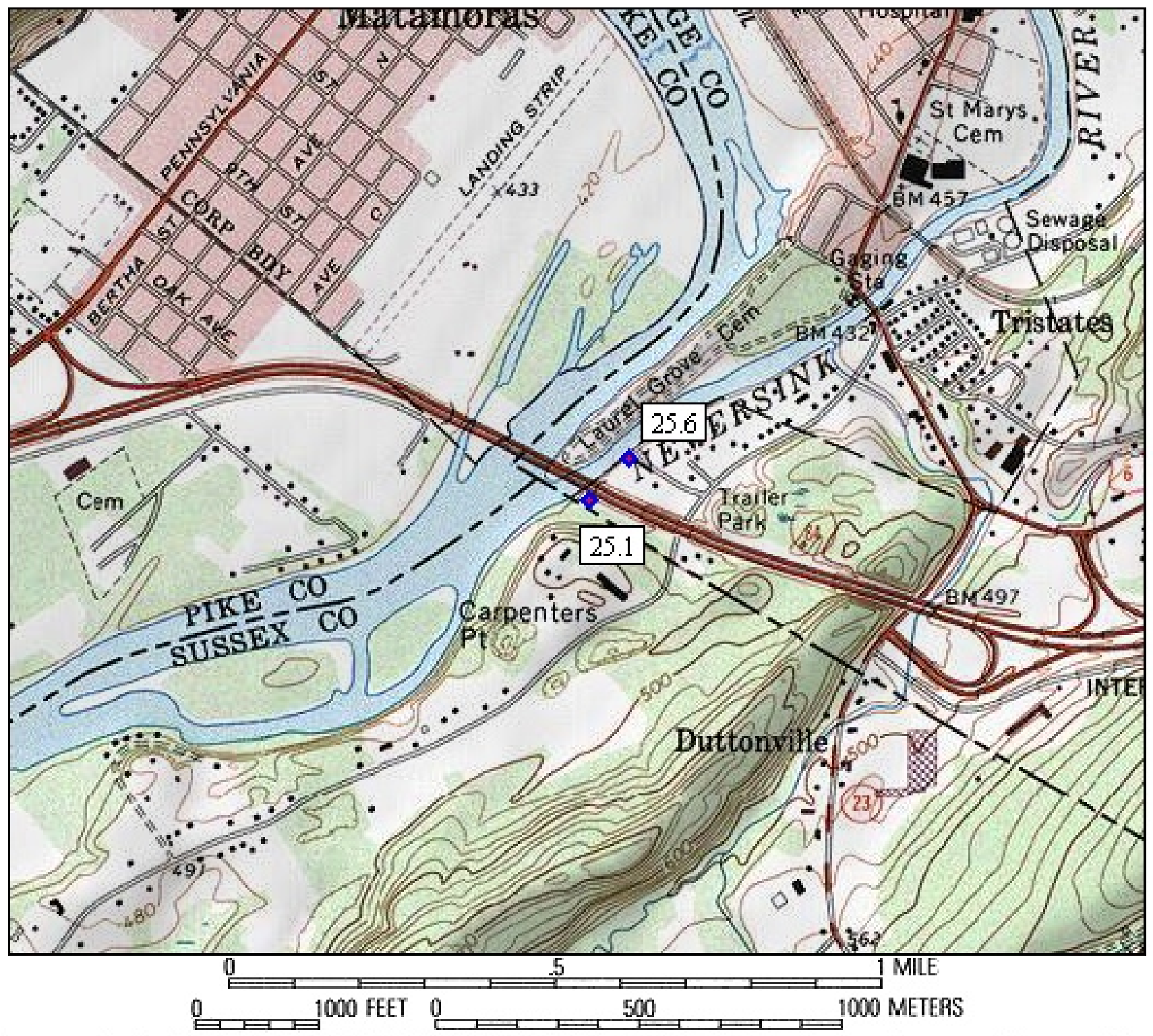

Map created with TOPO!(B) (02003 National Geographic (www.nationalgeographic.com/topo)

Port Jervis South quad map with location of site 25, Confluence of Delaware and Neversink Rivers at Interstate Route 84 at Port Jervis, N.Y. 


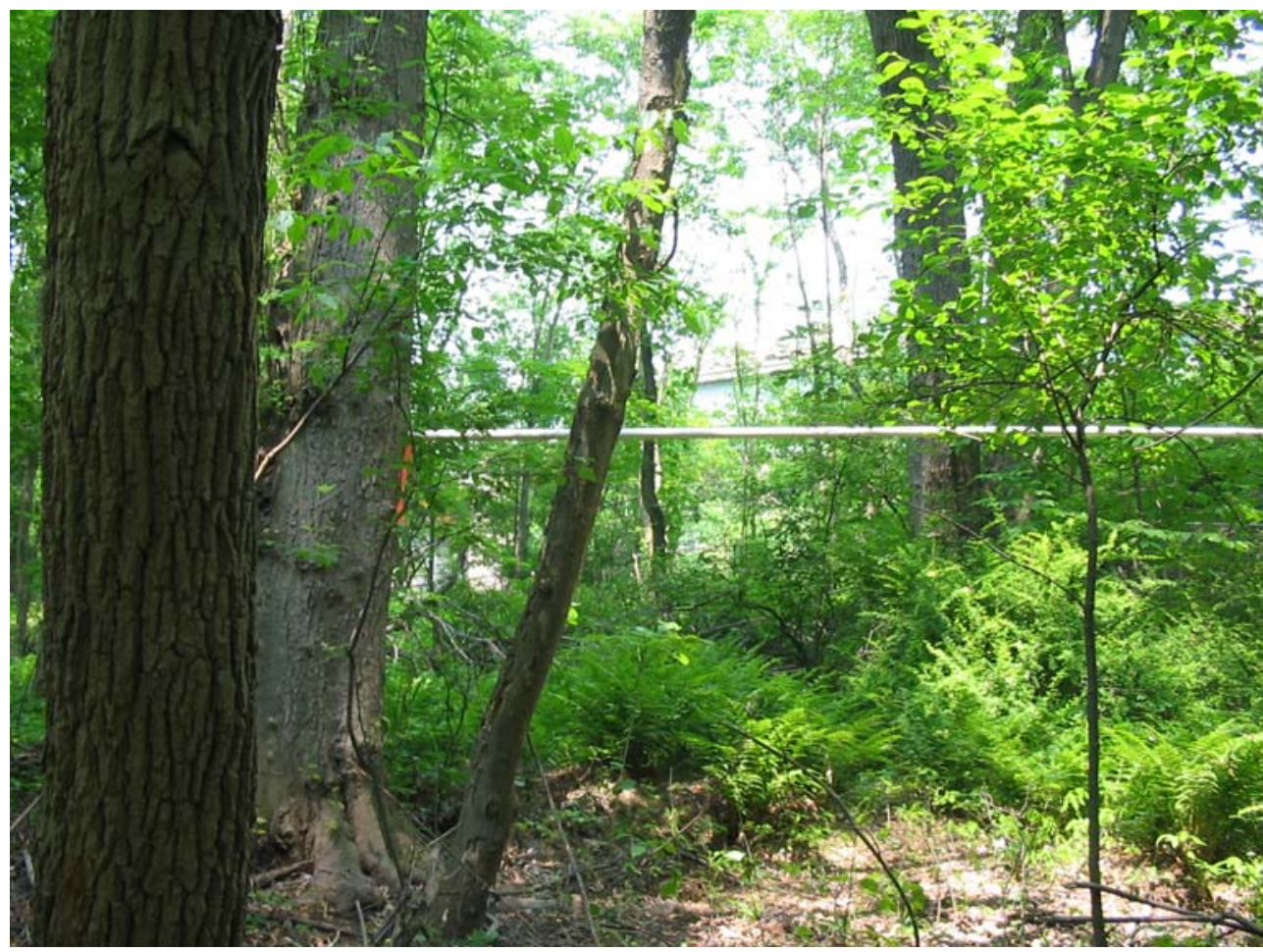

High-water mark 25.1 is an excellent seed line about 6 feet above the ground, on a tree on the left bank, 100 feet downstream from the eastbound (downstream) Interstate Route 84 bridge, at elevation 430.95 feet above NGVD 29 (lat $41^{\circ} 21^{\prime} 24.0^{\prime \prime}$, long $\left.74^{\circ} 41^{\prime} 36.3^{\prime \prime}\right)$.

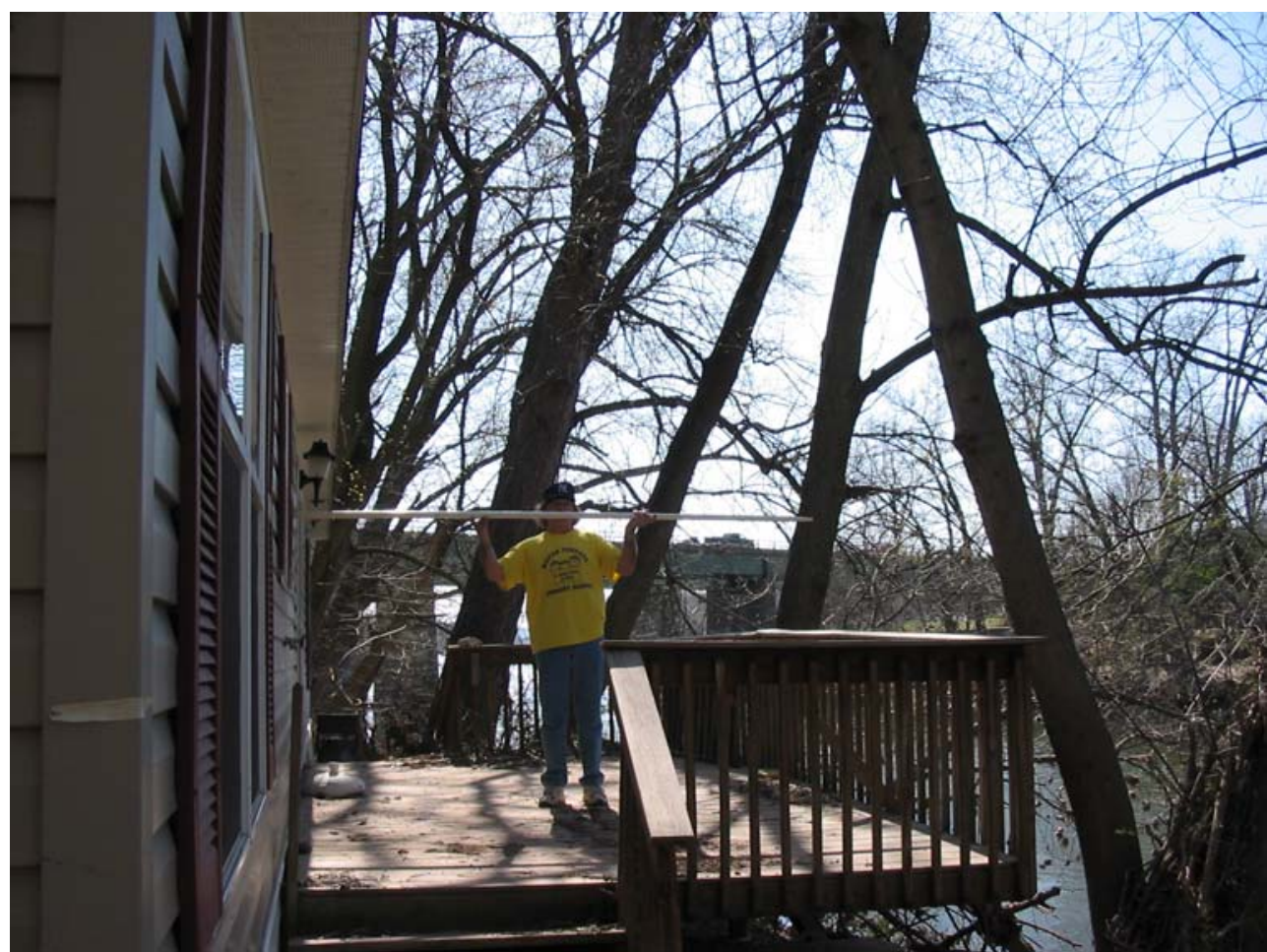

High-water mark 25.6 is an excellent seed line about 8 feet above the ground, on the streamward side of house 25 on Butler Road, on the left bank, 430 feet upstream from the westbound (upstream) Interstate Route 84 bridge, at elevation 430.95 feet above NGVD 29 (lat $41^{\circ} 21^{\prime} 28.0^{\prime \prime}$, long $74^{\circ} 41^{\prime} 33.1^{\prime \prime}$ ). 



\section{Appendix 2. Selected Photographs of Flood Damage During the Flood of April 2-3, 2005, in the Neversink River Basin and Surrounding Areas}




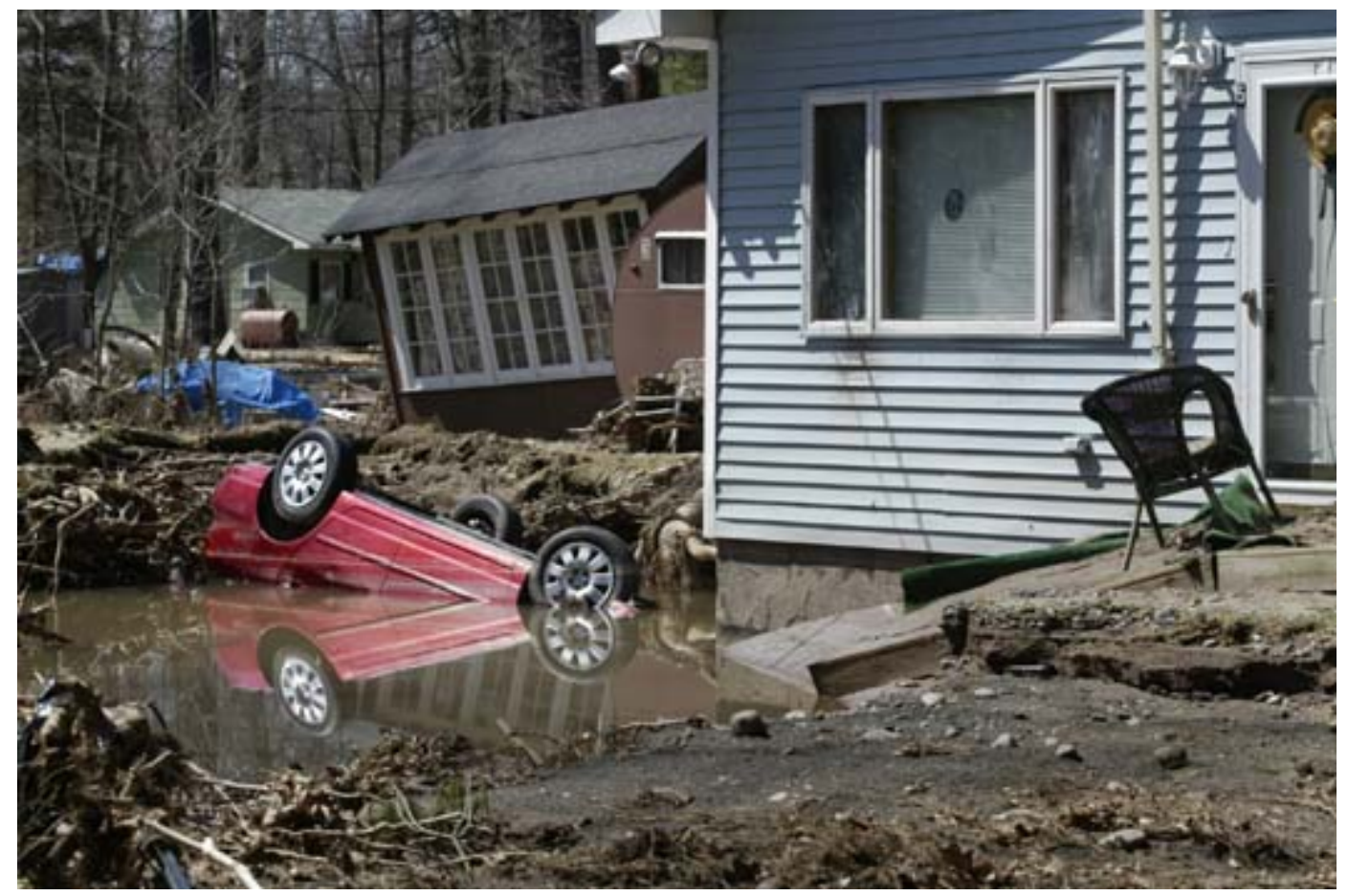

Flood damage caused by the Neversink River in Myers Grove. Photo courtesy of Times Herald-Record, taken by staff photographer Tom Bushey.

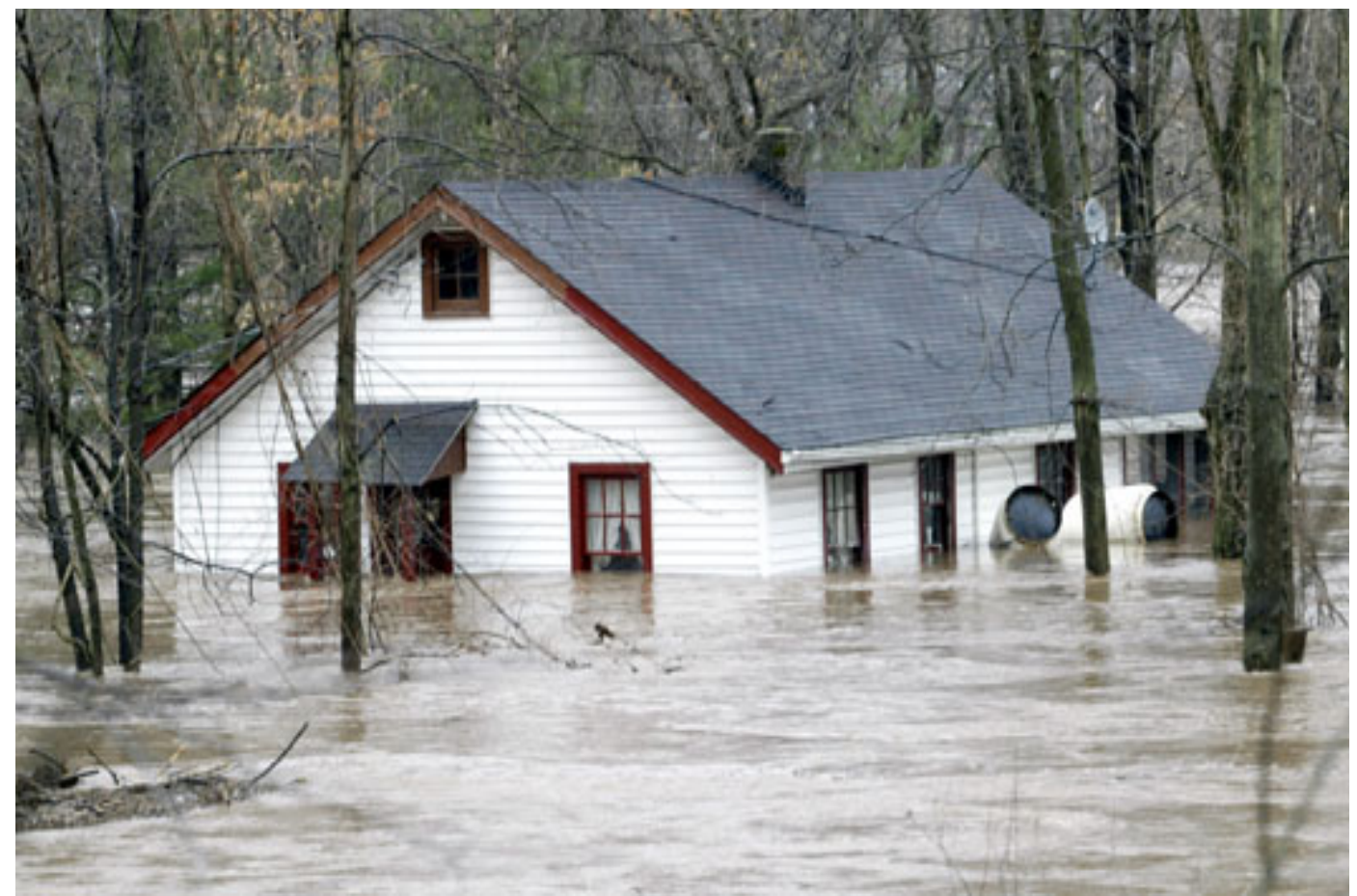

Home on Shawney Drive in Deerpark, New York flooded by the Neversink River on April 3, 2005. Photo courtesy of Times Herald-Record, taken by staff photographer Michele Haskell. 


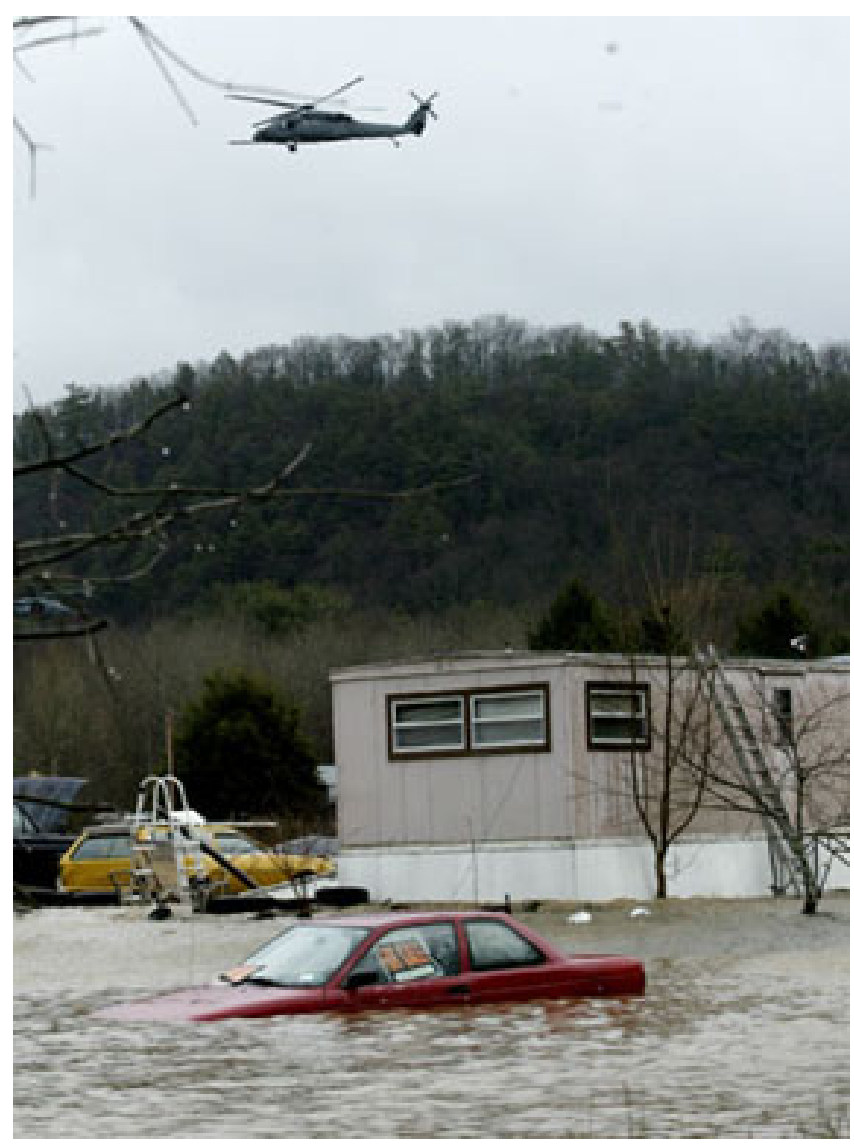

Blackhawk helicopter hovers above residents stranded in their homes on Shore Drive in Myers Grove, New York on April 3, 2005. Photo courtesy of Times Herald-Record, taken by staff photographer Michele Haskell. 


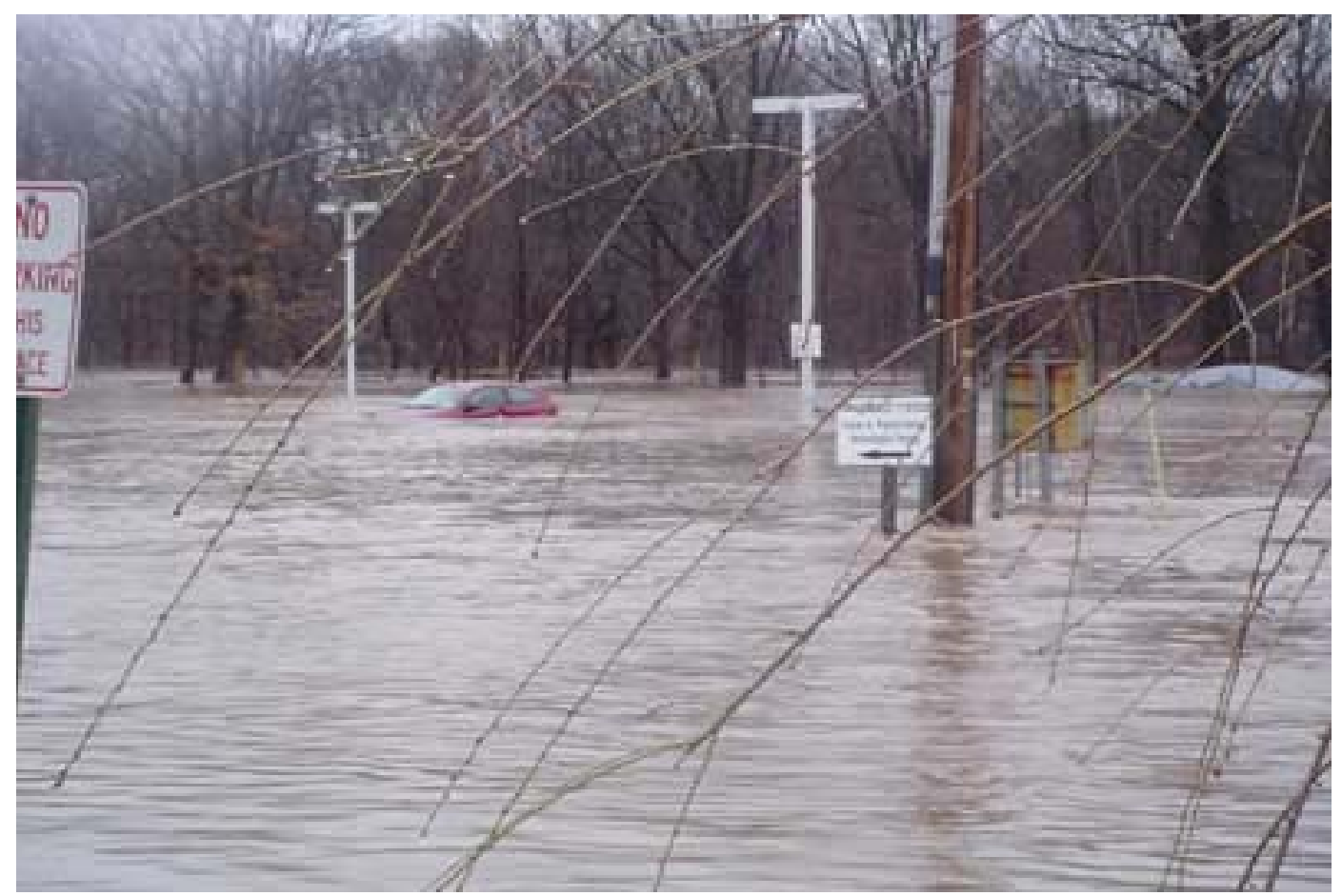

Parking lot behind Bon Secour Hospital on April 3, 2005, Port Jervis, New York. Photo courtesy of Times Herald-Record.

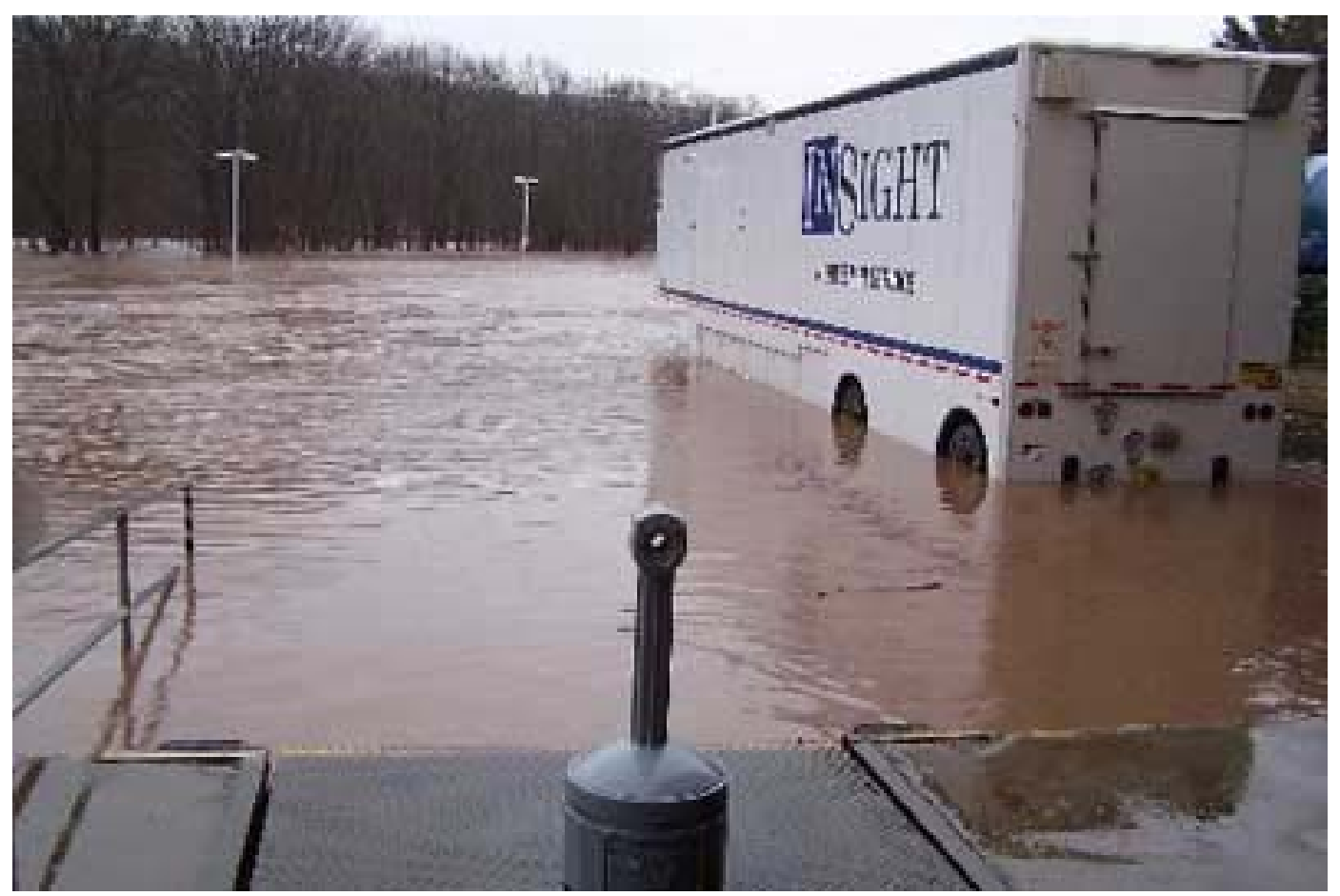

Magnetic resonance imaging (MRI) trailer at the Bon Secour Hospital on April 3, 2005. Photo courtesy of Times Herald-Record. 


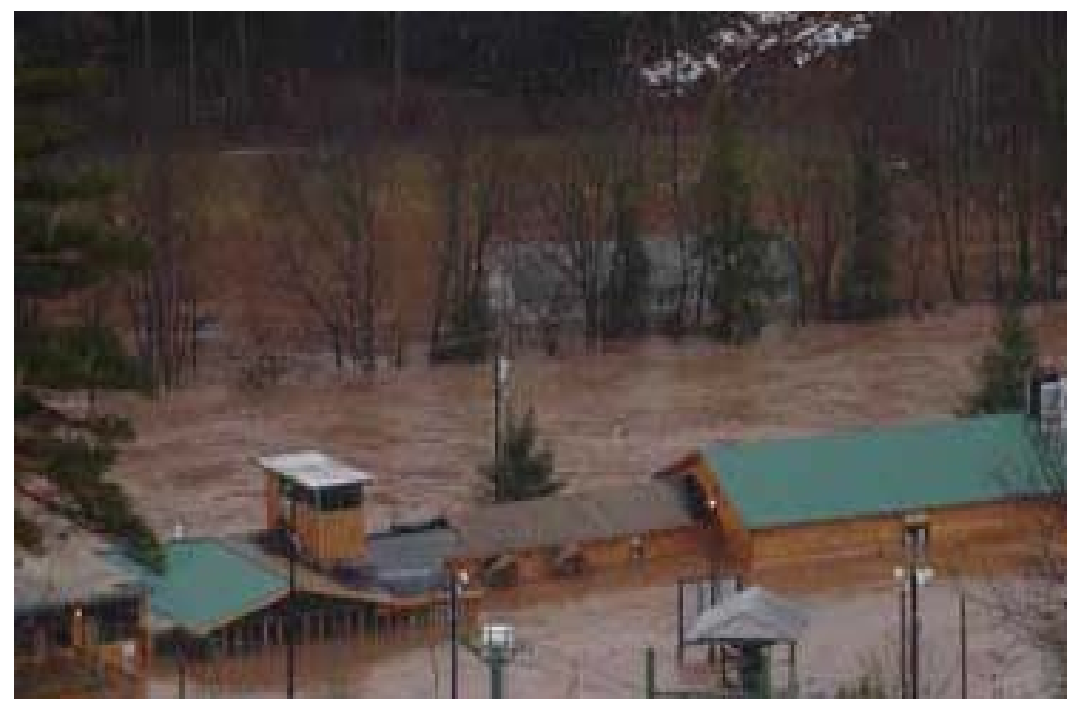

Holiday Mountain Fun Park flooded by Neversink River on April 3, 2005. Photo courtesy of Times Herald-Record.

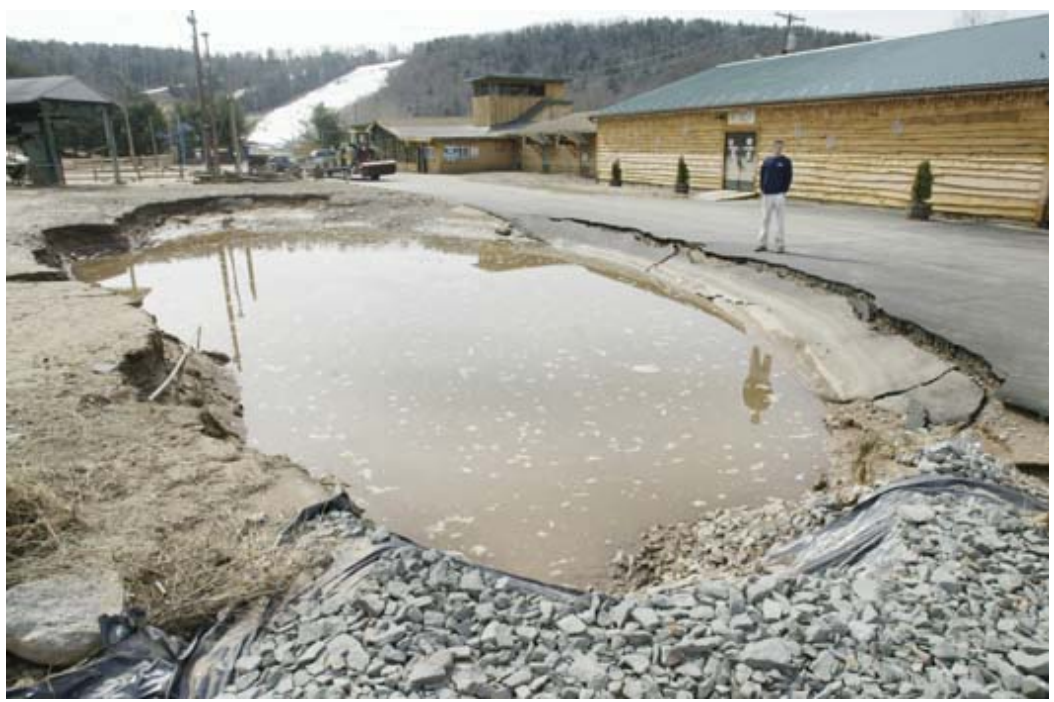

Neversink River damages Holiday Mountain Fun Park in Bridgeville. Photos courtesy of Times Herald-Record, taken by staff photographer Michele Haskell.

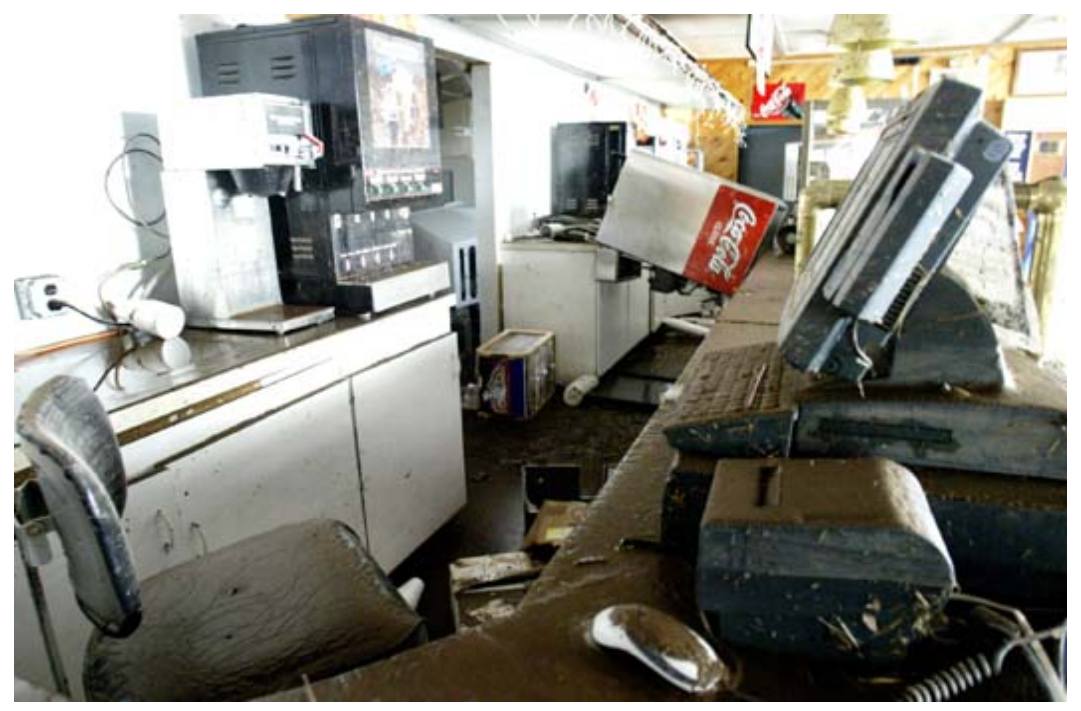




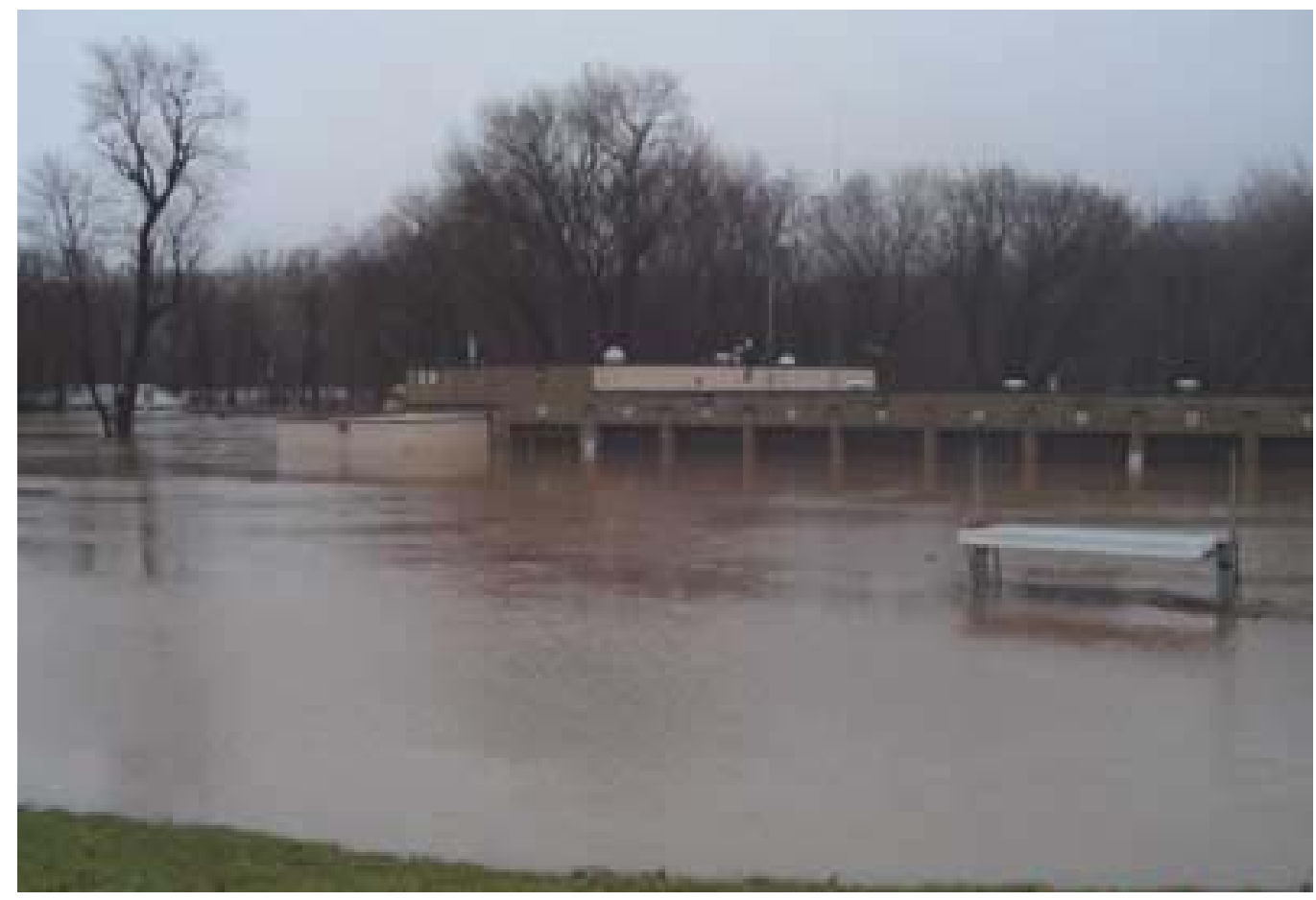

Port Jervis High School bus garage on April 3, 2005, Port Jervis, New York. Photos courtesy of Times Herald-Record.

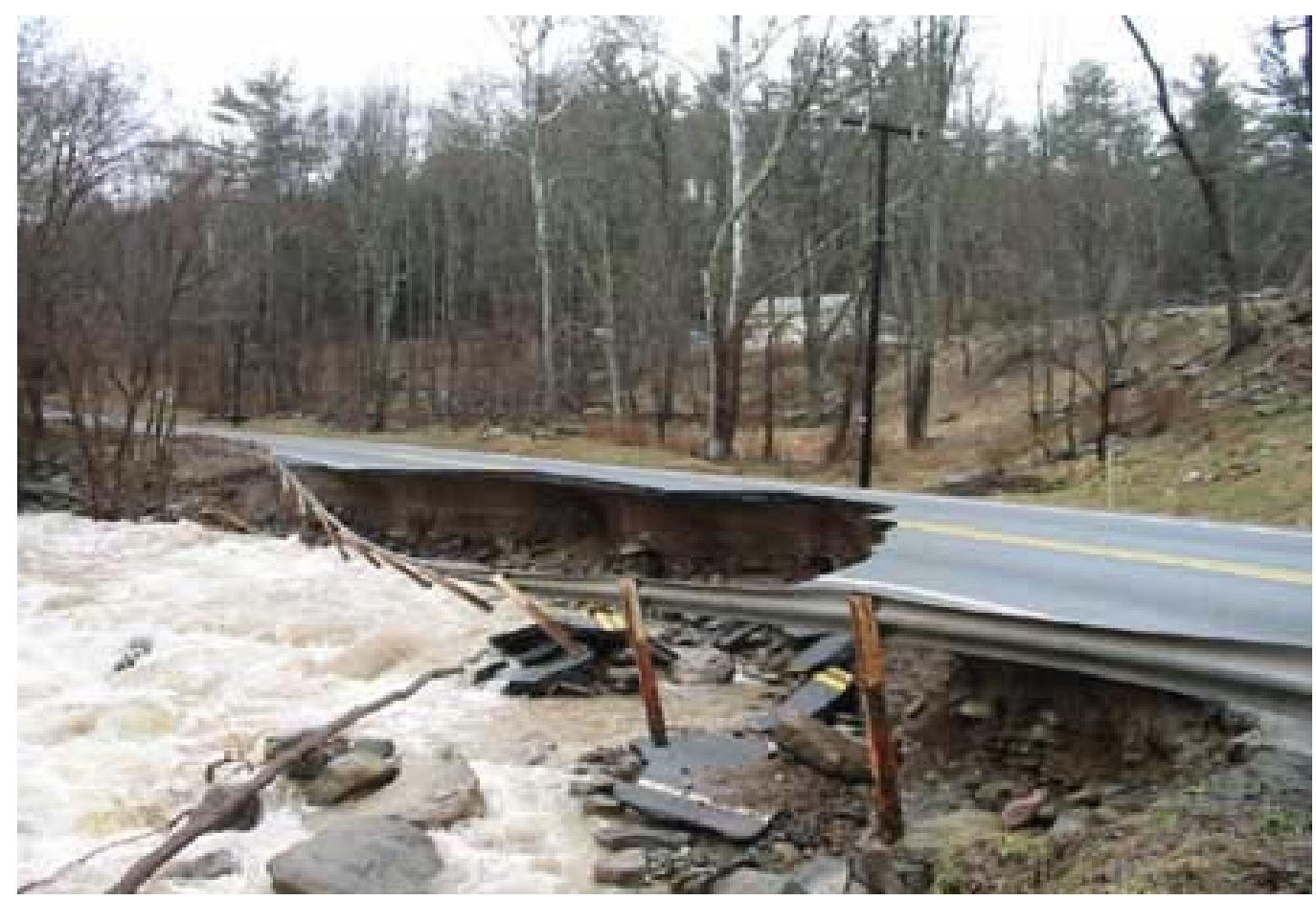

Damage to Oakland Valley Road in the Town of Deerpark, New York, April 3, 2005. Photos courtesy of Times Herald-Record. 
For more information concerning the research in this report, contact:

Rafael W. Rodriguez, Director

U.S. Geological Survey

New York Water Science Center

425 Jordan Road

Troy, NY 12180-8349

or visit our Web site at:

http://ny.water.usgs.gov 
오

옥 